JOSÉ EDUARDO FIGUEIREDO DE ANDRADE MARTINS

\title{
DUTY TO MITIGATE THE LOSS NO DIREITO CIVIL BRASILEIRO
}

Dissertação de Mestrado

Orientador: Professor Doutor Eduardo Tomasevicius Filho

FACULDADE DE DIREITO DA UNIVERSIDADE DE SÃO PAULO SÃO PAULO

2014 
JOSÉ EDUARDO FIGUEIREDO DE ANDRADE MARTINS

\section{DUTY TO MITIGATE THE LOSS NO DIREITO CIVIL BRASILEIRO}

Dissertação de mestrado apresentada ao Departamento de Direito Civil da Faculdade de Direito da Universidade de São Paulo, realizada sob orientação do Professor Doutor Eduardo Tomasevicius Filho.

FACULDADE DE DIREITO DA UNIVERSIDADE DE SÃO PAULO SÃO PAULO 
MARTINS, José Eduardo Figueiredo de Andrade. Duty to mitigate the loss no Direito Civil Brasileiro. São Paulo, 2014. Dissertação (Mestrado em Direito). Faculdade de Direito da Universidade de São Paulo.

Aprovado em:

Banca Examinadora

Prof. Doutor Eduardo Tomasevicius Filho (orientador)

Julgamento: Assinatura:

Prof.

Instituição:

Julgamento: Assinatura:

Prof.

Instituição:

Julgamento: Assinatura: 
Aos meus pais, Marcio e Carmen, por torcerem, apoiarem e confiarem na minha capacidade de superar todas as adversidades e de realizar os meus objetivos. Aos meus avós, Antonio José, Maria Angélica, Joaquim e Therezinha, porque sei que, de algum lugar, estão me observando e torcendo por mim. À minha tia-avó Enoe, pelo bom humor inabalável e pelas ótimas lembranças que para sempre guardarei no meu coração.

A Deus, por me conceder todos os dias a força necessária para seguir em frente, sem hesitar. 


\section{AGRADECIMENTOS}

Agradeço, primeiramente, ao professor Eduardo Tomasevicius Filho, por ter me acolhido como seu orientando, transmitindo-me dicas preciosas para o bom desenvolvimento desta dissertação. Muito obrigado pela amizade e por todo o comprometimento e dedicação ao ensino que pude aproveitar ao longo de toda a pós-graduação.

Aos professores Bernardo Bissoto Queiroz de Moraes e Francisco Paulo de Crescenzo Marino, pelas valiosíssimas críticas e sugestões feitas no exame de qualificação. Muitas das ideias apresentadas naquele dia foram o pontapé inicial para uma reflexão mais profunda do tema da dissertação.

Aos meus grandes amigos da especialização em Direito Constitucional da Pontifícia Universidade Católica de São Paulo, Heitor Villaça, Ana Cândida Mendonça, Diego Vietez, Carlos Vinícius Rosenburg e João Paulo Pessoa. Podem ter certeza que os debates e reflexões constitucionais aos sábados foram essenciais para eu ampliar o meu horizonte.

Aos meus amigos e colegas orientandos do mestrado, Andrea Silva Rasga Ueda e Patrícia Regina Mendes Mattos Corrêa Gomes, pelo compartilhamento, ainda que online, de experiências nesta árdua jornada da pesquisa jurídica.

Ao meu ex-chefe e amigo José Augusto de Lima Prestes, pelas reflexões quase que semanais sobre novidades jurídicas, que se tornam certamente momentos valiosos de aprendizagem.

Aos meus amigos “não-jurídicos”, Bruna Maudonnet, Renato Piton, Ivan Bortoto, Rafael Malavassi, Gabriel Kozma, Maria Julia Peruzzi e Vanessa Peres por todo o apoio e confiança no meu potencial. E claro, por suportarem meus devaneios jurídicos, tentando ajudar no que for possível, ainda que sem ter qualquer formação na área.

À Thaiz Branco, por todo o carinho, apoio, paciência e incentivo para continuar nesta caminhada. Tenha a certeza de que você foi essencial para que o desânimo não me atingisse.

Ao meu tio Fernando, pelo apoio e constante interesse no êxito desta jornada.

Por fim, agradeço a todos aqueles que, mesmo não nomeados - mas que sabem que me ajudaram muito! - de alguma forma contribuíram para que este trabalho fosse realizado. 
"Para las cosas grandes y arduas se necesitan combinación sosegada, voluntad decidida, acción vigorosa, cabeza de hielo, corazón de fuego y mano de hierro" 


\section{RESUMO}

Esta dissertação analisa a recepção do duty to mitigate the loss pelo Direito Civil brasileiro. Instituto com maior desenvolvimento nos países que adotam o sistema da common law, preceitua que a inobservância da mitigação pelo credor em face de um inadimplemento, seja evitando ou minimizando o prejuízo, faz com que ele não seja ressarcido do dano sofrido, pois referida conduta estava ao seu alcance. O estudo faz a contraposição dos conceitos de dever jurídico e ônus, extraindo-se a natureza jurídica do duty to mitigate the loss a partir da boa-fé. Posteriormente, são estabelecidos os seus pressupostos de existência, o que se convencionou chamar de pressuposto de exigibilidade processual e é feito um confronto com demais institutos de Direito Civil que possuem características semelhantes ou que podem se relacionar com a norma de mitigação. Parte-se, então, para o desenvolvimento do que se chamou de regra de aferição da razoabilidade, como meio de padronizar a verificação da medida que se pode considerar razoável para o credor adotar diante da incidência do duty to mitigate the loss. Logo após, é feito um levantamento jurisprudencial para avaliação da aplicação da norma de mitigação pelos tribunais brasileiros. Por fim, é analisada a presença do duty to mitigate the loss na Convenção das Nações Unidas sobre Contratos de Compra e Venda Internacional de Mercadorias (CISG) e em iniciativas internacionais.

Palavras-chave: duty to mitigate the loss; mitigação; boa-fé; ônus; regra de aferição da razoabilidade; CISG. 


\begin{abstract}
This dissertation analyzes the reception of the duty to mitigate the loss by the Brazilian Civil Law. Institute with further development in countries that adopt the common law system, states that the failure of mitigation by the creditor in case of breach, either avoiding or minimizing the damage, causes him to not be reimbursed for the damage suffered, because that conduct was within his reach. The study contrasts the concepts of duty and burden, extracting the legal nature of the duty to mitigate loss from the good faith. After, it is established their assumptions of existence, the so-called assumption of procedural enforceability and it is made a confrontation with other institutes of civil law that have similar characteristics or can relate to the standard mitigation. The next step is the development of what was called reasonableness admeasurement rule, as a means to standardize the verification of measures that can be considered reasonable for the creditor to take on by the incidence of the duty to mitigate loss. Immediately after, a survey is made for judicial review of the implementation of mitigation standard by Brazilian courts. Finally, it is analyzed the presence of the duty to mitigate the loss in the United Nations Convention on Contracts for the International Sale of Goods (CISG) and international initiatives.
\end{abstract}

Keywords: duty to mitigate the loss; mitigation; good faith; burden; reasonableness admeasurement rule; CISG. 


\section{SUMÁRIO}

INTRODUÇÃO 14

\section{TÍTULO I - REFERENCIAL TEÓRICO}

1. CONSIDERAÇÕES INICIAIS SOBRE O DUTY TO MITIGATE THE LOSS 17

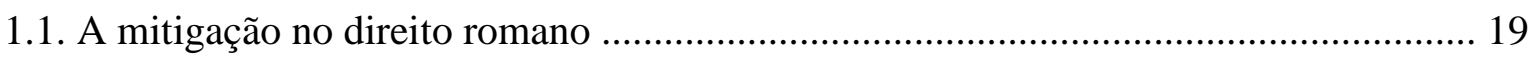

1.2. O duty to mitigate the loss na common law ............................................................... 24

1.2.1. A doutrina das consequências evitáveis .................................................... 24

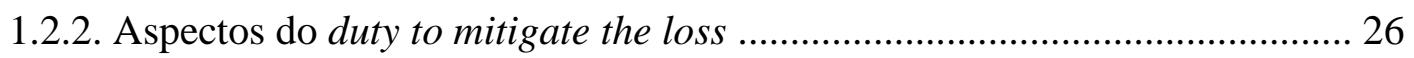

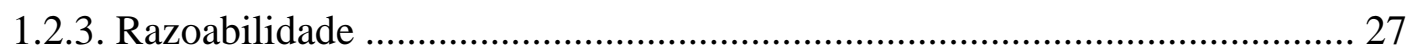

1.2.3.1. Operações substitutivas como medida razoável ........................... 30

1.2.3.1.1. Celebração de um novo contrato como operação

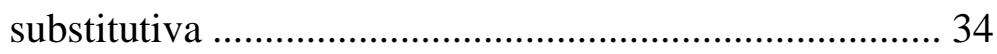

1.2.3.2. Insuficiência de recursos financeiros e medida razoável ............... 37

1.2.3.3. Reputação e medida razoável ....................................................... 39

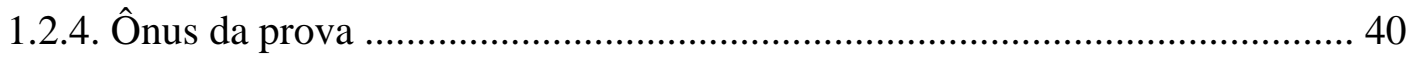

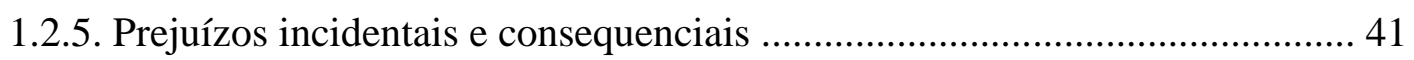

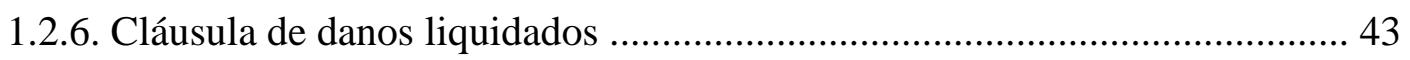

1.2.7. Jurisprudência do duty to mitigate the loss na common law ....................... 45

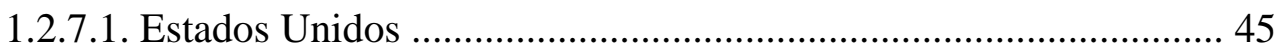

1.2.7.2. Inglaterra e País de Gales ........................................................... 47

2. NATUREZA JURÍDICA DO DUTY TO MTIIGATE THE LOSS ............................... 49

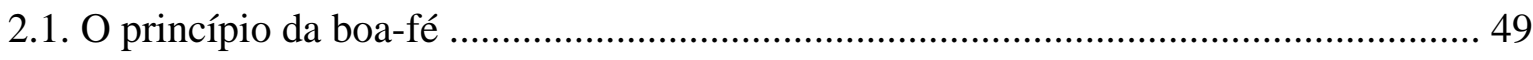

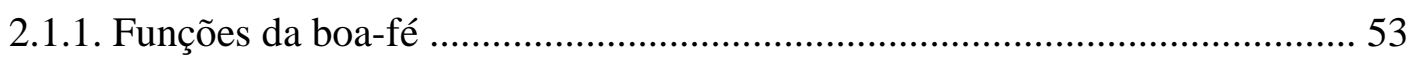

2.1.1.1. Função interpretativa e de colmatação ........................................ 54

2.1.1.2. Função criadora de deveres jurídicos anexos ............................... 55

2.1.1.2.1. Dever de cuidado ou proteção ....................................... 57

2.1.1.2.2. Deveres de lealdade e confiança recíproca ..................... 58

2.1.1.2.3. Deveres de confidencialidade e omissão ......................... 58

2.1.1.2.4. Dever de informação ...................................................... 59 
2.1.1.2.5. Dever de cooperação 63

2.1.1.2.5.1. Condutas esperadas no exercício do dever de cooperação 64

2.1.1.2.5.1.1. Facilitar o adimplemento 65

2.1.1.2.5.1.2. Manter a prestação interessante 67

2.1.1.2.5.1.3. Realizar da melhor maneira e de forma simples 68

2.1.1.2.5.2. Crise no dever de cooperação 69

2.1.1.2.6. Inviabilidade de um dever de mitigar o dano ................. 72

2.1.1.3. Função delimitadora do exercício de direitos subjetivos ............... 76

2.1.1.3.1. O ônus de mitigação 79

2.1.1.3.1.1. O ônus de mitigação e o dever de cooperação . 84

2.2. O abuso de direito 86

2.2.1. A proibição do venire contra factum proprium 92

2.3. Confronto da mitigação com outros institutos 94

2.3.1. Mitigação e cláusula penal 94

2.3.2. Mitigação e exceptio non adimpleti contractus ... 95

2.3.3. Mitigação e exercício tardio de um direito 96

2.3.3.1. Mitigação e suppressio 99

2.3.4. Mitigação e inversão do ônus da prova 100

2.3.5. Mitigação e contrato de seguro 102

2.3.6. Mitigação e gestão de negócios 103

2.3.7. Mitigação e dano moral 105

2.4. A impropriedade do termo duty 109

\section{TÍTULO II - O DUTY TO MITIGATE THE LOSS NO DIREITO INTERNO}

3. APLICAÇÃO DO DUTY TO MITIGATE THE LOSS

3.1. Introdução

3.2. Pressupostos de existência

3.2.1. Inadimplemento

3.2.2. Existência de prejuízo imputável ao devedor

3.2.2.1. Responsabilidade civil e o duty to mitigate the loss 
3.2.2.1.2. Pressupostos da responsabilidade civil 119

3.2.2.2. A causalidade 121

3.2.2.2.1. Culpa exclusiva da vítima e culpa concorrente 125

3.2.2.2.1.1. A experiência da culpa concorrente como fundamento no direito estrangeiro 128

3.2.3. Possibilidade razoável de o credor evitar ou amenizar os prejuízos 130

3.2.3.1. Momento para a tomada da medida razoável 133

3.3. Perdas e danos como pressuposto de exigibilidade processual 137

4. A REGRA DE AFERIÇÃO DA RAZOABILIDADE: AS CONSEQUÊNCIAS JURÍDICAS DO DUTY TO MITIGATE THE LOSS .................................................. 140

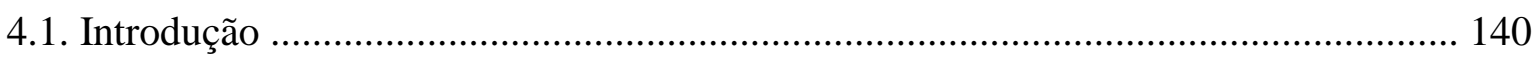

4.2. Uma nova proposta: a regra de aferição da razoabilidade ...................................... 141

4.2.1. A primeira parte da regra de aferição da razoabilidade ............................. 143

4.2.2. A segunda parte da regra de aferição da razoabilidade ............................. 146

4.2.2.1. A eficiência como terceira etapa para aferição do quantum indenizatório ............................................................................ 147

4.2.2.2. Lucros auferidos pelo credor com a mitigação: a quarta etapa .... 150

4.3. Análise comparativa dos elementos da regra de aferição da razoabilidade ............... 151

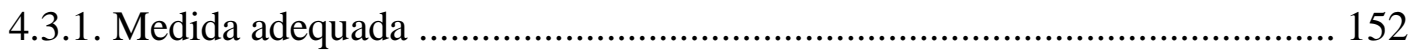

4.3.1.1. Não perigosa e não onerosa ...................................................... 152

4.3.1.2. Perigosa e não onerosa ............................................................. 153

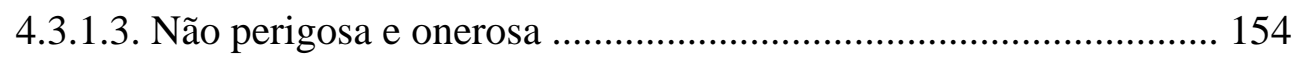

4.3.1.4. Perigosa e onerosa ................................................................. 156

4.3.2. Coexistência de medidas adequadas ....................................................... 157

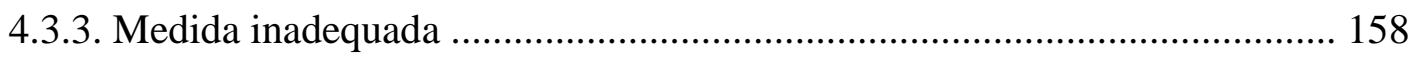

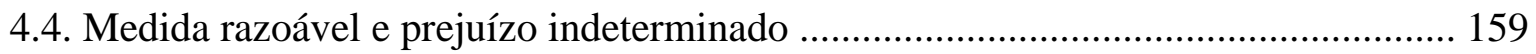

4.5. Consequências da inobservância do ônus de mitigação ........................................... 161

4.6. Caso fortuito, força maior e fato de terceiro ............................................................. 162

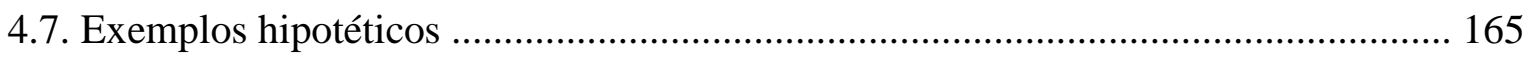

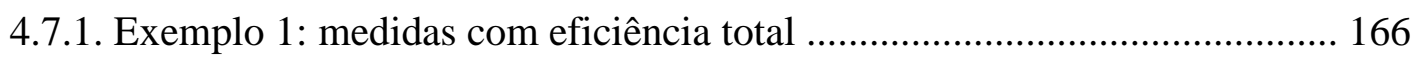

4.7.2. Exemplo 2: medida adequada com valor equivalente ao dano .................. 167

4.7.3. Exemplo 3: medidas com eficiência menor que o dano, mas maior que a medida adequada e não onerosa ............................................................. 168 
4.7.4. Exemplo 4: medidas com eficiência menor que o dano e que a medida adequada e não onerosa

4.7.5. Exemplo 5: medidas em que o credor aufere lucro 171

4.7.6. Exemplo 6: medidas em que o credor aufere lucro, sendo a medida não onerosa de mesmo valor que o dano e de eficiência menor que a medida onerosa

4.7.7. Exemplo 7: medida adequada e não onerosa sem gasto e oscilação de mercado

APÊNDICE: Síntese da regra de aferição da razoabilidade

5. O DUTY TO MITIGATE THE LOSS NA JURISPRUDÊNCIA BRASILEIRA

5.1. Decisões com aplicação correta do duty to mitigate the loss 182

5.1.1. Duty to mitigate the loss e medida inadequada 182

5.1.2. Medida de mitigação definida por cláusula contratual 183

5.1.3. Inobservância do duty to mitigate the loss

5.1.4. Duty to mitigate the loss e onerosidade

5.1.5. Duty to mitigate the loss e pagamento de dívida indevida 186

5.2. Decisões com aplicação parcialmente correta do duty to mitigate the loss 187

5.2.1. Duty to mitigate the loss, onerosidade e dever de informação do credor.... 187

5.2.2. Duty to mitigate the loss, verificação do quantum indenizatório e ônus probatório

5.2.3. Duty to mitigate the loss e dever de informação no processo

5.3. Decisões com aplicação incorreta do duty to mitigate the loss

5.3.1. Duty to mitigate the loss e exercício tardio de um direito

5.3.2. Duty to mitigate the loss como fator de redução dos danos morais in re ipsa

5.3.3. Duty to mitigate the loss como mitigação do prejuízo alheio

5.3.4. Duty to mitigate the loss como brocardo jurídico e dever de alegações processuais

5.3.5. Aplicação do duty to mitigate the loss ao invés da culpa concorrente

5.3.6. Aplicação do duty to mitigate the loss ao invés da culpa exclusiva da vítima

5.3.7. Cláusula penal e aplicação do duty to mitigate the loss como sinônimo de supressio e venire contra factum proprium 
5.3.8. Duty to mitigate the loss, dever de informação e renúncia de direito 202

5.3.9. Aplicação do duty to mitigate the loss ao invés da violação ao dever de informação 204

5.3.10. Cobrança indevida de tarifas bancárias e tributos incidentes em conta corrente inativa 205

\section{TÍTULO III - O DUTY TO MITIGATE THE LOSS NO COMÉRCIO INTERNACIONAL}

6. O DUTY TO MITIGATE THE LOSS NA CONVENÇÃO DAS NAÇÕES UNIDAS SOBRE CONTRATOS DE COMPRA E VENDA INTERNACIONAL DE

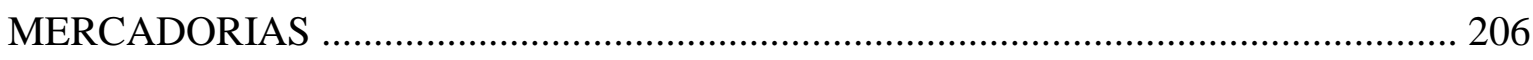

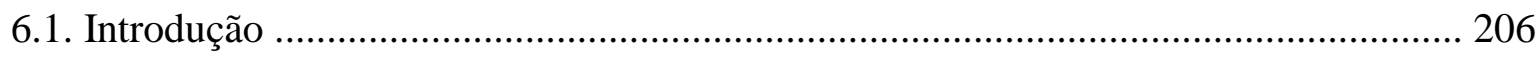

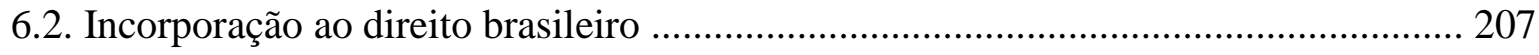

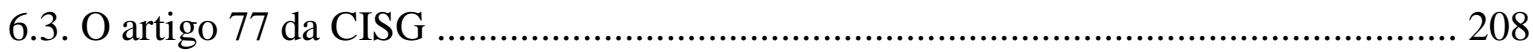

6.4. Exclusão da responsabilidade de mitigação ............................................................ 211

6.5. Hipóteses específicas de mitigação na CISG …..................................................... 213

6.6. Jurisprudência aplicando o artigo 77 da CISG ........................................................ 216

7. MITIGAÇÃO NAS INICIATIVAS INTERNACIONAIS ........................................ 219

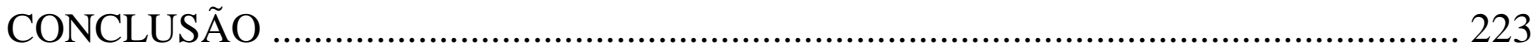

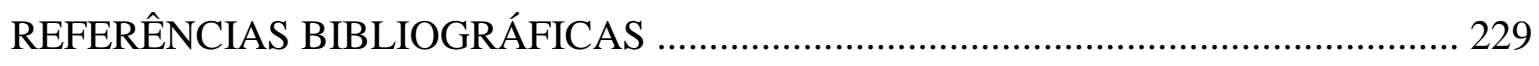




\section{INTRODUÇÃO}

Em razão de um inadimplemento, sofrendo o credor um prejuízo que poderia ter evitado, deverá mesmo assim ser indenizado pelo devedor? Trata-se da grande questão que norteia o instituto que se convencionou chamar de duty to mitigate the loss. Tendo em vista o equilíbrio econômico e jurídico das partes, a norma de mitigação tem o condão de solucionar o problema do agravamento do prejuízo causado pela inércia ou comportamento danoso da própria vítima, a qual deixa de tutelar devidamente o próprio patrimônio para que seja ressarcida pela parte inadimplente.

De fato, mesmo que pareça à primeira vista um problema singelo e, porventura, de fácil solução, o arcabouço jurídico que lhe atribui funcionalidade não o é. De pronto, já não é unânime, tanto internamente quanto nos demais países que foram estudados, a natureza jurídica do duty to mitigate the loss. Para alguns, trata-se de um dever, enquanto que, para outros, trata-se de um ônus. Esta divergência é um dos focos de estudo do Capítulo 2.

E não se trata igualmente de um conflito caracterizado pelo total ineditismo. Conforme será visto no Capítulo 1, indícios da norma de mitigação já são encontrados desde o século XVII nos países que adotam o sistema da common law. Mais do que isto, no próprio direito romano são localizados regramentos de situações específicas que muito se assemelham ao objeto deste estudo.

Ainda assim, a legislação brasileira não trouxe qualquer dispositivo que discipline explicitamente a matéria, o que causa perplexidade à doutrina quanto a sua recepção no direito pátrio. Mesmo aqueles que consideram o duty to mitigate the loss parte do sistema jurídico brasileiro, ainda divergem em relação aos seus fundamentos. Consoante será estudado nos Capítulos 2 e 3, são sugeridos o princípio da boa-fé, o abuso de direito, o venire contra factum proprium ou a responsabilidade civil como possíveis estruturas para introdução da norma de mitigação no Brasil.

Para o duty to mitigate the loss também não é unânime a sua aplicabilidade no âmbito extracontratual. Através da pesquisa dos trabalhos acadêmicos e jurisprudenciais dos países de common law, nota-se que ainda há uma grande resistência de desgarrá-lo do direito contratual, embora comece aos poucos ser notada tal tendência. Para o caso brasileiro, parece ser necessário tanto o desenvolvimento da mitigação no âmbito contratual quanto no extracontratual. Com efeito, os conflitos que surgem diariamente não 
são tão diferentes daqueles dos países que adotam o sistema da common law, mas o seu tratamento ainda é deficiente diante das estruturas em que se sustenta. Não se trata, portanto, de uma lacuna na legislação brasileira, mas de uma ausência inconcebível de arcabouço teórico consistente para a sua devida e correta aplicação. Tudo isto será analisado, sem prejuízo daquilo já desenvolvido no Capítulo 1, através dos pressupostos e confronto com demais institutos jurídicos nos Capítulos 2 e 3, mostrando que o duty to mitigate the loss deve ser aplicado tanto no direito contratual quanto no extracontratual.

Mesmo com o estabelecimento da estrutura e dos pressupostos, permanece a dúvida acerca de quais medidas o credor deve adotar para evitar ou minimizar o prejuízo. Afinal, qual medida é razoável dentro da concepção do duty to mitigate the loss? Para tanto, será desenvolvido no Capítulo 4 o que se chamou de regra de aferição da razoabilidade, a qual, através de partes e etapas bem definidas, auxilia tanto o credor a verificar como agir diante do caso concreto em que há incidência da norma de mitigação quanto o magistrado a decidir se o credor agiu corretamente. Além disso, para comprovar a viabilidade da regra, são propostos ao final do Capítulo exemplos hipotéticos aplicando-a nas diversas combinações fáticas possíveis.

Sedimentadas as respostas para os questionamentos propostos, é a seguir realizado no Capítulo 5 um levantamento jurisprudencial nos Tribunais brasileiros, para que sejam verificadas as aplicações, se corretas ou não, do duty to mitigate the loss nos casos trazidos a eles para processamento e julgamento. Demonstrar-se-á a prevalência de decisões judiciais que o aplicam incorretamente ou com parcial correção.

A norma de mitigação não é exclusiva de tratativas internas, estando presente também na Convenção das Nações Unidas sobre Contratos de Compra e Venda Internacional de Mercadorias (CISG). Esta dissertação também se ocupa em analisar as peculiaridades no Capítulo 6, inclusive através de análise jurisprudencial.

Por fim, são vistas no Capítulo 7 as iniciativas internacionais, diplomas e estudos voltados para o comércio internacional que não envolvem diretamente o Brasil, mas evidenciam a importância do duty to mitigate the loss sobretudo no direito contratual. Em muitas situações, quando possível, suas normas são comparadas às da CISG.

Assim, sinteticamente, esta dissertação está dividida em três Títulos. O primeiro, Referencial Teórico, é composto pelo Capítulo 1, que faz considerações iniciais sobre a norma de mitigação e pelo Capítulo 2, que trata de sua natureza jurídica advinda do 
princípio da boa-fé. O Título II, "O duty to mitigate the loss no direito interno" abarca o Capítulo 3, que trata da aplicação da norma de mitigação no direito civil brasileiro, o Capítulo 4, que desenvolve a regra de aferição da razoabilidade e o Capítulo 5, que realiza levantamento jurisprudencial acerca da aplicação do duty to mitigate the loss pelos Tribunais brasileiros. O Título III, nomeado "O duty to mitigate the loss no comércio internacional" se divide entre o Capítulo 6, que trata exclusivamente da CISG e o Capítulo 7 , que destaca as iniciativas internacionais. 


\section{TÍTULO I - REFERENCIAL TEÓRICO}

\section{CONSIDERAÇÕES INICIAIS SOBRE O DUTY TO MITIGATE THE LOSS}

Apesar de haver indícios de mitigação na Antiguidade para situações bastante específicas ${ }^{1}$, é certo que a origem do duty to mitigate the loss se deu nos países que seguem o sistema da common law. Sob diversas alcunhas, como mitigation principle ou doctrine of avoidable consequences, a norma de mitigação foi desenvolvida paulatinamente pela doutrina e pela jurisprudência dos países de common law, sendo traçados os seus próprios contornos, o que contribuiu para estabelecê-la como um instituto autônomo².

No começo, o duty to mitigate the loss se desenvolveu basicamente no âmbito contratual, como um remédio para solucionar o desequilíbrio causado pela desídia do credor que nada faz para mitigar seu prejuízo quando assim puder. Só que a diversidade dos fatos e a relevância que adquiriu para a solução de conflitos no direito contratual fez com que também fosse transportado para o âmbito extracontratual ${ }^{3}$. E dada a recente ampliação deste entendimento, questões de suma importância ainda são objeto de bastante controvérsia tanto na doutrina quanto na jurisprudência estrangeira ${ }^{4}$.

Em linhas gerais, a ideia central da norma de mitigação é a seguinte: tornando-se a parte contrária inadimplente, a parte prejudicada tem que agir razoavelmente para mitigar as suas perdas e danos, pois caso contrário não terá direito à indenização pelos prejuízos que sofreu. A partir desta assertiva, já se podem extrair três mandamentos:

(1) A parte prejudicada não recuperará as perdas que poderia ter evitado se tivesse tomado medidas razoáveis. Seria esperado que ela se comportasse como se não houvesse nenhuma reclamação a ser feita para a recuperação das perdas.

(2) A parte prejudicada recuperará como prejuízo todos os custos e despesas incorridas na adoção de medidas razoáveis para a mitigação dos prejuízos.

(3) O pedido de perdas e danos da parte prejudicada deve ser ajustado para levar em consideração o montante de perdas evitadas ou, em casos excepcionais, o

\footnotetext{
${ }^{1}$ Vide item 1.1., infra.

2 Tema a ser desenvolvido no item 1.2., infra.

3 TRONCOSO, María Isabel. La obligación de tomar medidas razonables para evitar la extensión del daño. Revista de Derecho Privado, n ${ }^{\circ}$ 1, p. 353-391, julho-dezembro de 2011. p. 384.

${ }^{4}$ Vide a respeito, por exemplo, o Título II, Capítulo 2, item. 2.3.7. e item 1.2 infra.
} 
montante de perdas incorridas na tomada de medidas razoáveis para a mitigação dos prejuízos 5 .

Com o objetivo precípuo de evitar o desperdício econômico ${ }^{6}$, o duty to mitigate the loss se apresenta como um importante instrumento de equilíbrio e justiça nas relações jurídicas obrigacionais. Enquanto implica a incumbência de a parte prejudicada não se manter inerte e mitigar prejuízos que podem ser por ela evitados, evita também que a parte inadimplente seja penalizada a indenizar por perdas e danos os quais não teve participação, isto é, que apesar de terem relação com o inadimplemento, só existiram porque a parte prejudicada não agiu como teria que agir.

Assim, se um vendedor de produtos perecíveis não toma medidas razoáveis para conservá-los na ocorrência do inadimplemento do comprador, como estocá-los em um equipamento de refrigeração ou vendê-los a terceiro - sendo estas medidas razoáveis diante do caso concreto -, estará agindo em desacordo com o duty to mitigate the loss. Não poderá ser indenizado pelo prejuízo havido com a perda do produto por ter estragado, pois tinha condições de mitigá-lo e mesmo assim não o fez.

Extrai-se disso, então, que um dos aspectos nucleares da norma de mitigação é a evitabilidade ${ }^{7}$, isto é, a possibilidade razoável que o credor tem de evitar ou minimizar os prejuízos decorrentes do inadimplemento do devedor. Trata-se do controle da situação, do alcance do poder do credor de alterar o rumo das consequências gravosas que está sofrendo ou sofrerá diante da inobservância do devedor de sua obrigação. Se a adoção de uma medida está dentro daquilo que as circunstâncias permitem, sem que exija um esforço além do razoável do credor, significa que o prejuízo é evitável e incide no caso o duty to mitigate the $\operatorname{loss}^{8}$, atraindo-lhe um ônus ${ }^{9}$ de reagir para que o prejuízo não se alastre, não exista ou, então, deixe de existir.

Algumas considerações importantes devem ser feitas desde logo. Quando neste estudo for utilizado o vocábulo "prejuízo", se quer englobar tanto as perdas quanto os

\footnotetext{
${ }^{5}$ BATES, Paul J. A Mitigation of Damages: A Matter of Commercial Common Sense. Advocate's Quarterly, v. 13, n. 3, p. 273-307, jan. 1992. p. 274.

${ }^{6}$ HILLMAN, Robert A. Keeping the Deal Together After Material Breach: Common Law Mitigation Rules, the UCC, and the Restatement (Second) of Contracts. University of Colorado Law Review. v. 47, p. 553-615, 1976. p. 558

${ }^{7}$ Tradução literal de avoidability, neologismo utilizado na common law para tratar deste aspecto do duty to mitigate the loss.

${ }^{8}$ Esta discussão será retomada no Título II, Capítulo 3, item 3.2.3., e no Capítulo 4, aonde será proposta uma nova abordagem à aferição da razoabilidade das medidas a serem tomadas pelo credor.

${ }^{9}$ Em relação à questão de ser um ônus ou um dever, vide Capítulo 2, itens 2.1.1.2.6. e 2.1.1.3.1. infra.
} 
danos. Na mesma esteira, quando se diz "mitigação", pretende-se fazer referência tanto ao ato de evitar quanto ao de minimizar o prejuízo. Estes esclarecimentos facilitarão o entendimento da amplitude das expressões utilizadas de agora em diante.

Nota-se, assim, que por trás de um simples mandamento se escondem inúmeras questões e problemas, que vão desde os fundamentos até as consequências de sua aplicação. E as divergências já se iniciam a partir da nomenclatura que o popularizou.

\subsection{A mitigação no direito romano}

É preciso um cuidado redobrado quando se trabalha com o direito romano. Muitos dos problemas atuais não existiam ou não incomodavam os romanos a ponto de serem elaboradas soluções jurídicas próprias. Tratar-se-ia, portanto, de um equívoco realizar interpretações de institutos romanos com olhos modernos, pois há o risco de se obter significados equívocos, além do que aquela civilização quis dizer em seus escritos ${ }^{10}$. Neira ${ }^{11}$, contudo, adverte que a ausência de bagagem jurídica atual tornaria impossível a identificação de certos problemas e a falta de intenção de explicitar um determinado sentido não remete à conclusão de que não há, implicitamente, o sentido obtido pelo intérprete atual. Até porque em diversas oportunidades os romanos não davam um nome específico, mas chegavam a soluções que conhecemos muitas vezes com nomenclatura determinada. Por isso, fazer esta análise comparativa é, de qualquer maneira, um risco inevitável ${ }^{12}$.

Aplica-se referido entendimento à norma de mitigação. Ainda que os romanos não dispusessem de uma norma geral acerca da necessidade de a parte prejudicada evitar ou minimizar seu prejuízo, algumas situações referenciadas no Corpus Iuris Civilis $^{13}$ trazem

\footnotetext{
${ }^{10}$ SÁENZ, Alfonso Castro. Metodologia y ciência jurídica: hacia un concepto de derecho romano. Revista de estudios histórico-jurídicos. Valparaíso, $\mathrm{n}^{\circ} \quad 24, \quad 2002 . \quad$ Disponível em: http://www.scielo.cl/scielo.php?script=sci_arttext\&pid=S0716-54552002002400001\&lng=es\&nrm=iso.

Acesso em 10 de março de 2014.

${ }^{11}$ NEIRA, Lílian C. San Martín. La carga del perjudicado de evitar o mitigar el daño : Estudio históricocomparado. Bogotá: Universidad Externado de Colombia, 2012. p. 37.

${ }^{12}$ Neira exemplifica com os deveres jurídicos anexos do princípio da boa-fé que, embora não eram assim referenciados pelos romanos, estavam presentes no seu sistema jurídico (Ibidem).

${ }^{13} \mathrm{O}$ imperador Justiniano tinha como projeto a unificação e expansão do império bizantino e, para tanto, via a necessidade de criar uma legislação congruente e capaz de atender às demandas e litígios vivenciados à época. Por isso, redigiu, compilou e explicou inúmeras normas e (hoje chamada de) jurisprudência em obra que foi designada como Corpus Iuris Civilis pelo romanista francês Dionísio Godofredo em 1583. A obra
} 
consigo a noção de que a indenização não poderá ser total, dependendo da postura adotada pelo credor. Implicitamente, há uma noção de mitigação, mesmo que incorporada pelas ideias de limitação de responsabilidade e de culpa.

Como não poderia deixar de ser, do mesmo modo que ocorre no direito italiano, alemão e português, isto é, aqueles ordenamentos jurídicos que têm suas raízes fincadas no próprio direito romano, os elementos da culpa e da limitação do dever de indenizar são muito fortes, traçando fundamentalmente um possível ônus de mitigação a partir da relação de causalidade e participação culposa da vítima no incremento do dano. Neste ponto, então, não há uma aproximação no tratamento dado pela common law ao duty to mitigate the loss, que o enxerga como uma doutrina autônoma ${ }^{14}$.

Podem ser encontrados no Digesto diversos dispositivos nos quais têm como extrair a norma de mitigação. O D.50.17.203 prescreve: "quod quis ex culpa sua damnum sentit, non intellegitur damnum sentire" (aquele que sofre qualquer prejuízo por sua própria culpa não é considerado ter sido prejudicado). Embora aqui se trate do caso da culpa exclusiva da vítima como excludente de responsabilidade, é certo que, estendendo a sua interpretação, pode-se extrair parte dos ditames da norma de mitigação. Afinal, todos os danos decorrentes da inobservância da norma de mitigação, os quais poderiam ser evitados ou minimizados, são imputados ao credor e, por conseguinte, não terá este direito à indenização. São danos sofridos por sua exclusiva culpa, já que deixou de evitar o prejuízo por meio de medidas razoáveis, impossíveis de serem imputados ao devedor inadimplente.

Na mesma esteira, o D.21.1.23.8 traz situação bastante específica em que é possível verificar certa incidência da norma de mitigação. Caso o escravo roube alguma coisa do comprador ou de qualquer outra pessoa que o próprio comprador seja obrigado a restituir, o comprador não está obrigado a devolver o escravo, até que o vendedor o indenize. Se o vendedor não quiser receber o escravo, ele não terá que indenizar o comprador além do preço determinado pelo pretor, e o comprador deve sofrer este prejuízo por sua culpa, já que poderia ter entregado o escravo como forma de reparação, mas preferiu pagar os prejuízos estimados ${ }^{15}$.

está dividida em quatro partes: Digesto (também chamado de Pandectas, seu nome grego), Institutas, Novelas e Código (Codex).

${ }^{14}$ Vide item 1.2. infra.

${ }^{15}$ Quare sive emptori servus furtum fecerit sive alii cuilibet, ob quod furtum emptor aliquid praestiterit, non aliter hominem venditori restituere iubetur, quam si indemnem eum praestiterit. Quid ergo, inquit Iulianus, si noluerit venditor hominem recipere? Non esse cogendum ait quicquam praestare, nec amplius quam pretio 
Nota-se em referido dispositivo a limitação da responsabilidade pela culpa própria do comprador, já que não será indenizado integralmente pelo vendedor, mas somente pelo preço, conforme determinado pelos juízes. A sua culpa acaba influindo diretamente no valor da indenização, já que não agiu adequadamente.

O D.9.2.52pr está inserido nas disposições relativas à Lex Aquiliae e, dessa forma, trata da responsabilidade extracontratual. Nele é tratada a responsabilidade sobre a morte do escravo em razão de golpes, podendo ser proposta ação pelas lesões se elas não surgiram em razão da ignorância do médico ou da negligência do dono ${ }^{16}$. É outro caso de exclusão de responsabilidade, em que o autor dos golpes não se responsabiliza pelo resultado danoso. A culpa foi exclusiva do dono do escravo e, por isso, não poderá se responsabilizar o autor dos golpes pela inobservância de cuidado daquele nas suas atividades.

No Digesto também está presente um exemplo bastante próximo ao que se compreende atualmente como norma de mitigação no D.19.2.60.2. Alude que se o limpador de lã perder a sua vestimenta, e você tiver meios de recuperá-la, mas não lançar mão delas, poderá propor ação de aluguel contra o limpador de lã. O juiz, contudo, decidirá se não era a melhor opção você propor ação contra o próprio ladrão e recuperar sua propriedade dele às custas do limpador de lã. Se o pretor decidir que esta ação era impossível, então julgará a favor de você e o obrigará a ceder seus direitos de ação ao limpador de $\mathfrak{a}^{17}$.

Dentre os exemplos aqui trazidos, talvez este seja um dos que fica mais evidente a regra de aferição da razoabilidade aqui a ser desenvolvida por nós. Em primeiro lugar, o proprietário da vestimenta tem a opção de selecionar a medida mais conveniente para recuperá-la. Se achar conveniente, a norma considerada razoável a cobrança de aluguel pela vestimenta do limpador de lã. O pretor, então, apreciará a medida adotada pelo proprietário, verificando se era a mais razoável em face da possibilidade de propositura de ação diretamente contra o ladrão. Em comparação com o que será desenvolvido neste

condemnabitur: et hoc detrimentum sua culpa emptorem passurum, qui cum posset hominem noxae dedere, maluerit litis aestimationem sufferre: et videtur mihi Iuliani sententia humanior esse.

${ }^{16}$ Si ex plagis servus mortuus esset neque id medici inscienta aut domini neglegentia accidisset, recte de iniuria occiso eo agitur.

${ }^{17}$ Vestimenta tua fullo perdidit et habes unde petas nec repetere vis: agis nihilo minus ex locato cum fullone, sed iudicem aestimaturum, an possis adversus furem magis agere et ab eo tuas res consequi fullonis videlicet sumptibus: sed si hoc tibi impossibile esse perspexerit, tunc fullonem quidem tibi condemnabit, tuas autem actiones te ei praestare compellet. 
estudo acerca da regra de aferição da razoabilidade ${ }^{18}$, a decisão do proprietário da vestimenta de qual medida tomar se encontra em conformidade com a primeira parte da regra e a apreciação do juiz com a segunda parte.

Outro dispositivo em que é possível encontrar uma relação com a norma de mitigação é o D.19.1.21.3. Trata-se de limitação dos prejuízos os quais o comprador pode pedir ressarcimento quando o vinho não é entregue pelo vendedor. Considera razoável o comprador propor ação pleiteando o valor do próprio vinho, e não o que ele poderia lucrar se revendesse o vinho. Para tanto, a norma inclusive faz comparação com uma compra de trigo e, não entregando o vendedor a mercadoria, os escravos sofrem de fome: o valor do trigo é o que deve ser pleiteado e não o equivalente à morte dos escravos. Também especifica que a obrigação não encarece com a oscilação do mercado, pois considera o valor do momento em que o vinho deveria ter sido entregue, e não do momento do efetivo cumprimento da obrigação. O vendedor, ainda que posteriormente, deve entregar os vinhos conforme pactuado ${ }^{19}$.

Interessante em primeiro lugar ressaltar a questão da extensão dos danos que o comprador pode pleitear. A distinção da norma não é, como na common law, em razão da previsibilidade do dano, mas a partir do seu distanciamento da causa ${ }^{20}$. Seria o equivalente aos efeitos diretos e imediatos os quais o artigo 403 do Código Civil brasileiro atualmente faz referência ${ }^{21}$.

O segundo ponto interessante diz respeito a questão da oscilação do valor de mercado. Consoante foi estudado em relação à CISG e será visto na common law, a elevação ou redução do valor de mercado afeta diretamente o quantum indenizatório, sobretudo quando realizada uma operação substitutiva ${ }^{22}$. A solução no direito romano é diversa, pois se dá maior relevância ao momento em que a obrigação deveria ter sido cumprida e ao cumprimento da obrigação in natura, ainda que em momento diferido. Tal

\footnotetext{
${ }^{18}$ Vide Título II, Capítulo 4 infra.

${ }^{19}$ Cum per venditorem steterit, quo minus rem tradat, omnis utilitas emptoris in aestimationem venit, quae modo circa ipsam rem consistit: neque enim si potuit ex vino puta negotiari et lucrum facere, id aestimandum est, non magis quam si triticum emerit et ob eam rem, quod non sit traditum, familia eius fame laboraverit: nam pretium tritici, non servorum fame necatorum consequitur. Nec maior fit obligatio, quod tardius agitur, quamvis crescat, si vinum hodie pluris sit, merito, quia sive datum esset, haberem emptor, sive non, quoniam saltem hodie dandum est quod iam olim dari oportuit.

${ }^{20}$ Vide item 1.2.1.

${ }^{21}$ Quanto aos problemas desta expressão e da resolução do problema pelo viés puramente causal, vide o Título II, Capítulo 3, item 3.2.2.2.

${ }^{22}$ Conforme Título III, Capítulo 6, item 6.5. e item 1.2.3.1. infra.
} 
solução parece ecoar no ordenamento jurídico brasileiro, por conta da prevalência do cumprimento da obrigação em espécie em detrimento da conversão em perdas e danos ${ }^{23}$.

Por fim, o D.18.6.1 traz situação bastante curiosa em que o vendedor poderá realizar o que atualmente é chamado de operação substitutiva para mitigar o seu prejuízo. Dispõe a norma que o vendedor poderá derramar o vinho caso esteja marcada uma data para a sua medição e isto não é feito. O derramamento, contudo, tem que ser feito na presença de testemunhas e com notificação prévia do comprador. É considerado louvável por parte do vendedor, no entanto, que o vinho não seja derramado e exigir uma compensação pelo uso dos barris, que seriam utilizados para outra atividade (como arrendamento) ou se teria que alugar outros por causa do seu uso. É, ainda, preferível que não derrame o vinho, alugando outras embarcações e não entregar o vinho enquanto o aluguel dos demais não é pago pelo comprador ou vender o vinho em boa-fé. Em outras palavras, fazer tudo sem prejudicar a si mesmo e diminuir o máximo possível a perda do comprador $^{24}$.

Talvez este seja o dispositivo com a maior evidência da norma de mitigação no direito romano, já que não só trata das medidas razoáveis que o vendedor pode adotar para mitigar o prejuízo da possível perda do vinho, como também diz, de forma até genérica para a situação, que o vendedor tem que fazer de tudo para não prejudicar a si mesmo e, consequentemente, não agravar a situação do comprador. O vendedor até tem o poder de dispor do vinho, mas não o faz para minimizar o máximo possível os danos do inadimplemento do comprador.

Caso o D.18.6.1 tivesse sido levado adiante nas codificações mais modernas e tido seus termos ampliados para casos além da compra e venda de vinhos, os sistemas jurídicos derivados da tradição romano-germânica poderiam ter trazido uma norma específica tratando da mitigação. Ainda que de modo casuístico, os pressupostos próprios do duty to mitigate the loss estão presentes ${ }^{25}$, quais sejam: o inadimplemento (pela falta na data

\footnotetext{
${ }^{23}$ Vide Título II, Capítulo 3, item 3.3.

${ }^{24}$ Licet autem venditori vel effundere vinum, si diem ad metiendum praestituit nec intra diem admensum est: effundere autem non statim poterit, priusquam testando denuntiet emptori, ut aut tollat vinum aut sciat futurum, ut vinum effunderetur. Si tamen, cum posset effundere, non effudit, laudandus est potius: ea propter mercedem quoque doliorum potest exigere, sed ita demum, si interfuit eius inania esse vasa in quibus vinum fuit (veluti si locaturus ea fuisset) vel si necesse habuit alia conducere dolia. Commodius est autem conduci vasa nec reddi vinum, nisi quanti conduxerit ab emptore reddatur, aut vendere vinum bona fide: id est quantum sine ipsius incommodo fieri potest operam dare, ut quam minime detrimento sit ea res emptori.

${ }^{25}$ Conforme Fernández, ainda que o direito romano não tenha reconhecido plenamente o ônus da mitigação, foi nele que se assentaram as suas bases (FERNÁNDEZ, Maximiliano Rodríguez. Concepto y alcance del deber de mitigar el daño en el derecho internacional de los contratos. Revista de Derecho Privado, $\mathrm{n}^{\circ} 15$,
} 
estipulada para a medição do vinho), existência de prejuízo imputável ao devedor (pelo vinho que não foi adquirido tempestivamente e sujeito à derramamento) e possibilidade de o credor mitigar o prejuízo (com o aluguel ou arrendamento dos barris e demais medidas que diminuem o seu prejuízo e o agravamento da situação do comprador). É possível que, com a falta de amplitude e repetição desta regra, o duty to mitigate the loss como instituto autônomo ou reconhecidamente derivado da boa-fé teve maior dificuldade de difusão nos ordenamentos enraizados no direito romano.

\subsection{O duty to mitigate the loss na common law}

\subsubsection{A doutrina das consequências evitáveis}

Nos países que adotam a common law, o duty to mitigate the loss está inserido dentro da doctrine of avoidable consequences (doutrina das consequências evitáveis). $\mathrm{O}$ credor tem que mitigar o dano decorrente do inadimplemento do devedor através de razoáveis condutas positivas, ou seja, através de uma postura comissiva. Seu propósito principal é evitar as perdas econômicas do credor resultantes dos prejuízos sofridos que poderiam ter sido mitigados se tivesse agido razoavelmente ${ }^{26}$.

A primeira decisão que se tem notícia acerca do duty to mitigate the loss data do século XVII, de 1677.

O requerente tinha sido contratado para transportar mercadorias para Ipswich e deixá-las no lugar a ser indicado pelo requerido. Ao chegar ao destino, entretanto, este demorou mais de seis horas para proceder a tal indicação, fazendo com que os cavalos do requerente ficassem muito tempo expostos ao sol e ao cansaço, morrendo em seguida. O Tribunal, entretanto, negou o direito à indenização pela perda dos animais, afirmando que foi insensatez do requerente deixá-los esperando, uma vez que poderia ter retirado deles a carroça ou deixado as mercadorias em qualquer lugar em Ipswich $^{27}$.

\footnotetext{
Universidad Externado de Colombia, 2008. Disponível em: http://www.cisg.law.pace.edu/cisg/biblio/rodriguez-fernandez.html. Acesso em: 10.03.2014)

${ }^{26}$ HILLMAN, Robert A. Keeping the Deal Together After Material Breach: Common Law Mitigation Rules, the UCC, and the Restatement (Second) of Contracts. University of Colorado Law Review. v. 47, p. 553-615, 1976. p. 558.

${ }^{27}$ LOPES, Christian Sahb Batista. A mitigação dos prejuízos no direito contratual. Belo Horizonte, 2011. Tese (Doutorado em Direito). Faculdade de Direito da Universidade Federal de Minas Gerais. p. 22.
} 
Embora a doutrina das consequências evitáveis seja atualmente tratada como um conceito autônomo, por muitas vezes foi tratada conjuntamente com a causalidade, a culpa concorrente e o distanciamento das consequências de um ato ilícito (remoteness of the consequences of a wrong $)^{28}$. E a mistura de cada uma delas com o a doutrina das consequências evitáveis merece a crítica apropriada.

No tocante à causalidade e à culpa concorrente, Litvinoff ${ }^{29}$ realiza competente crítica ao dizer que nem sempre o prejuízo é fruto da relação causal entre credor e devedor, podendo ter outras origens, formando, por conseguinte, outros nexos causais. O modo como a parte prejudicada reage pode ser a própria causa do prejuízo, quebrando o nexo causal e, portanto, não guardando semelhança o bastante para as doutrinas serem tratadas como desdobramentos de um mesmo instituto ${ }^{30}$.

Já quanto ao distanciamento das consequências de um ato ilícito, a análise é feita puramente pela via da possibilidade de a parte, no momento da celebração do contrato, prever as consequências danosas. O cerne desta doutrina, portanto, fica no embate entre a possibilidade de previsão (foreseeability) e o distanciamento (remoteness) dos danos.

Aqueles que se apoiam na doutrina do remoteness of the consequences of a wrong ainda se dividem em dois grupos: aqueles que defendem que a doutrina das consequências evitáveis deriva do acordo de vontade das partes (agreement-centred model) e aqueles que compreendem como uma imposição legal (reasonable foreseeability model) ${ }^{31}$. Ambos os modelos são criticáveis.

O modelo baseado no acordo de vontades falha ao explicar a aplicação da norma de mitigação nos casos de mera responsabilidade civil, já que na maioria das vezes inexiste pacto prévio entre as partes. Além disso, a previsão do distanciamento é certa, específica, principalmente em se tratando de um acordo de vontades. Esta especificidade falta à norma de mitigação, pois se refere genericamente a prejuízos que o credor razoavelmente deixou de $\operatorname{evitar}^{32}$.

\footnotetext{
${ }^{28}$ LITVINOFF, Saúl. Damages, Mitigation, and Good Faith. Tulane Law Review, New Orleans, v. 73, p. 1161-1195, 1999. p. 1169.

${ }^{29}$ Idem, ibidem. p. 1170.

${ }^{30} \mathrm{O}$ tema voltará a ser desenvolvido no Capítulo 3 .

${ }^{31}$ DYSON, Andrew. Explaining the Avoidable Loss Rule of Mitigation. SLS Conference, Cambridge, 8 de setembro de 2011. p. 6-7.

${ }^{32}$ Idem, ibidem. p. 8.
} 
Já o modelo da imposição legal falha ao não estabelecer um critério fechado de razoabilidade, ou seja, não se define o que é ou não razoável. A previsão do que é razoável acaba se tornando uma explicação incompleta para o problema ${ }^{33}$.

Além de tais problemas, há definitivamente entre o duty to mitigate the loss e o remoteness of the consequences of a wrong uma diferença fundamental: o momento em que se afere a incidência de cada uma. Enquanto a doutrina do distanciamento das consequências de um ato ilícito é aferível no momento da celebração do contrato, a norma de mitigação incide no momento do inadimplemento ${ }^{34}$. Isto faz com que ambas não possam ser tratadas como um instituto singular.

Por fim, como uma doutrina autônoma, a norma de mitigação tem aplicação tanto no direito contratual quanto na responsabilidade civil nos países de common law, ainda que seja mais comum encontrar exemplos jurisprudenciais e estudos sobre aquele ramo. As características na aplicação e consequências jurídicas são idênticas, mudando apenas a relação jurídica que serve como pano de fundo ${ }^{35}$.

Com a previsão da doutrina das consequências evitáveis em diversos diplomas e pela franca adoção pela jurisprudência - conforme se verá adiante no desenvolvimento deste capítulo -, pode-se dizer que a norma de mitigação se encontra bastante consolidada nos países que adotam a common law.

\subsubsection{Aspectos do duty to mitigate the loss}

Os estudiosos que se aprofundam no estudo da doutrina das consequências evitáveis identificam um aspecto negativo e outro positivo no duty to mitigate the loss, tratando-os como verdadeiras funções de recuperação do instituto ${ }^{36}$. Não deixa de ser uma mera classificação doutrinária, mas é de importante menção, pois explicita o funcionamento da norma de mitigação na common law e é também aplicável ao caso brasileiro.

\footnotetext{
${ }^{33}$ Idem, ibidem. p. 9. O problema da razoabilidade na common law será tratado adiante no item 1.2.3.

${ }^{34}$ LITVINOFF, Saúl. Damages, Mitigation, and Good Faith. Tulane Law Review, New Orleans, v. 73, p. 1161-1195, 1999. p. 1170-1171.

${ }^{35}$ KLEIN, Kevin C.; HININGER, Nicole G. Mitigation of Psychological Damages: An Economic Analysis of the Avoidable Consequences Doctrine and Its Applicability to Emotional Distress Injuries. Oklahoma City University Law Review, v. 29, p. 405-439, 2004. p. 409-410.

${ }^{36}$ Idem, ibidem. p. 408.
} 
$\mathrm{O}$ aspecto negativo (negative recovery rule) trata da impossibilidade de o credor recuperar os prejuízos os quais tinham como qualidade serem razoavelmente evitáveis ${ }^{37}$. É a obstrução da possibilidade de o credor ser indenizado por prejuízos que tinha como mitigar, seja evitando ou minimizando. $\mathrm{O}$ aspecto negativo evidencia a limitação (ou até exclusão) de um crédito que o credor diz ter.

O aspecto positivo (positive recovery rule), por sua vez, ao invés de tratar da perda, diz respeito à possibilidade de o credor recuperar as despesas que teve para mitigar o prejuízo. Assim, sendo observada a norma de mitigação, isto é, adotando o credor medidas razoáveis para evitar ou minimizar o dano, poderá ser indenizado pelo devedor de tudo aquilo que incorreu para efetivá-las.

Tanto o aspecto positivo quanto o negativo existem na common law no direito contratual e no direito extracontratual ${ }^{38}$. Estando a relação jurídica estruturada em um contrato ou não, o credor não terá direito a recuperar as perdas causadas pelos danos evitáveis e poderá se ressarcir das despesas que incorreu na adoção da medida razoável.

\subsubsection{Razoabilidade}

A razoabilidade é uma questão nuclear no desenvolvimento da doutrina das consequências evitáveis na common law. É sabido que o duty to mitigate the loss não é absoluto $^{39}$, e isto fica claro até mesmo nos diplomas legais. O $\S 350$ do Restatement (Second) of Contracts e o artigo 2002 do Código Civil da Louisiana fazem expressa menção aos esforços razoáveis que o credor tem que tomar para evitar o seu prejuízo, sob pena de ter a indenização pleiteada limitada pelo valor do dano que deixou de mitigar. A legislação, no entanto, não define o que seria um esforço razoável, deixando a cargo tanto da doutrina quanto da jurisprudência interpretar a expressão, determinando o seu alcance semântico.

No caso inglês British Westinghouse Electric and Manufacturing Co Ltd v. Underground Electric Railways Co of London Ltd, 1912, A.C. 673, a razoabilidade foi um importante ponto colocado em discussão no julgamento, já que antes mesmo da análise

\footnotetext{
${ }^{37}$ Idem, ibidem.

${ }^{38}$ Idem, ibidem. p. 410.

39 EVERETT, John C. Mitigation of Damages - Effect of Plaintiff Choosing Among Reasonable Alternatives. Arkansas Law Review. Arkansas, v. 23, p. 132-135, 1969-1970. p. 132.
} 
sobre o lucro obtido pela Underground Electric Railways Co of London Ltd com a troca das turbinas, era preciso saber se a medida tomada foi razoável no caso. E o Visconde Haldane L.C., em sua manifestação, consignou que um esforço razoável não é nada além do que um homem prudente faria ordinariamente no comando dos seus negócios ${ }^{40}$.

Por "ordinariamente no comando dos seus negócios", a doutrina e a jurisprudência decorrente deste julgamento entendem que existem potenciais medidas que não se pode esperar que o credor adote tendo em vista as circunstâncias do caso ${ }^{41}$. A jurisprudência sedimentada a partir do artigo 2002 do Código Civil da Louisiana também segue a mesma linha de entendimento, inclusive quando recorre à comparação da atuação de um homem prudente se submetido às mesmas circunstâncias ${ }^{42}$.

É razoável aquilo que um homem prudente faria naquelas circunstâncias, mas isto não significa que a parte não deverá empregar os melhores esforços para mitigar o prejuízo $^{43}$. Em uma relação contratual, por exemplo, é esperado que o credor se esforce da mesma maneira se não tivesse ocorrido o inadimplemento. Neste diapasão, a norma de mitigação na common law tem também o escopo de fomentar as partes a pensarem em ajustes para impedir contingências danosas ${ }^{44}$, materializadas a partir de cláusulas específicas de mitigação ${ }^{45}$.

O mero esforço, se razoável, merece o reconhecimento da doutrina das consequências evitáveis $^{46}$. A sua insuficiência para evitar ou minimizar todo o dano não faz com que o esforço seja imprestável para o duty to mitigate the loss, só não será o bastante para que o credor consiga se ressarcir de todo o prejuízo que sofreu. Há uma

40 MACDONALD, Elizabeth; KOFFMAN, Lawrence. The Law of Contract. $6^{\mathrm{a}}$ ed. Oxford: Oxford University Press, 2007. p. 583-584.

41 BATES, Paul J. A Mitigation of Damages: A Matter of Commercial Common Sense. Advocate's Quarterly, v. 13, n. 3, p. 273-307, jan. 1992. p. 275.

${ }_{42}$ LITVINOFF, Saúl. Damages, Mitigation, and Good Faith. Tulane Law Review, New Orleans, v. 73, p. 1161-1195, 1999. p. 1187.

${ }^{43}$ GOETZ, Charles J.; SCOTT, Robert E. The mitigation principle: toward a general theory of contractual obligation. Virginia Law Review. v. 69, p. 967-1024, setembro de 1983. p. 1016.

${ }^{44} \mathrm{O}$ que no direito pátrio é preenchido pelo princípio da boa-fé em seu dever jurídico anexo de cooperação, conforme será visto no Título I, Capítulo 2, item 2.1.1.2.5. Sobre as cláusulas de danos liquidados na common law,vide item 1.2.6. infra. No tocante às cláusulas penais brasileiras e a mitigação, vide Título II, Capítulo 2, item 2.3.1.

${ }^{45}$ GOETZ, Charles J.; SCOTT, Robert E. The mitigation principle: toward a general theory of contractual obligation. Virginia Law Review. v. 69, p. 967-1024, setembro de 1983. p. 1017-1018. FORTIN, Lisa A. Why There Should Be a Duty to Mitigate Liquidated Damages Clauses. Hofstra Law Review. v. 38, p. 285318, 2009-2010. p. 288.

${ }^{46}$ FORTIN, Lisa A. Why There Should Be a Duty to Mitigate Liquidated Damages Clauses. Hofstra Law Review. v. 38, p. 285-318, 2009-2010. p. 292. 
valorização, portanto, do aspecto positivo da norma de mitigação, demandando que o credor seja prudente, e não perfeito em suas atitudes.

A atenção dada pelas Cortes ao esforço traz enormes dificuldades para a defesa nos processos indenizatórios. O primeiro problema surge a partir do ônus probatório, já que inúmeras informações relevantes se encontram em poder do credor ou a produção da prova demanda tempo além do disponível no processo. Em razão disso, a tese defendida pelo credor de que mesmo sem resultados concretos se esforçou para mitigar os danos acaba prevalecendo.

Também merece atenção o fato de que o desespero e a situação de emergência são igualmente considerados para entender relevante e razoável o esforço do credor, ainda que não tenha sido obtida a mitigação nos moldes desejáveis. No caso Banco de Portugal v. Waterlow \& Sons Ltd [1932] A.C. 452 (H.L.), citado por Bates ${ }^{47}$, o Lorde MacMillan se manifestou que é mais fácil criticar as medidas adotadas após o fim da emergência, o que não é aceitável por alguém que a criou. Para ele, a lei não admite que o credor adote medidas além das razoáveis, mas não é porque existiam medidas menos razoáveis apontadas pela parte inadimplente que a tomada pelo credor deve ser desconsiderada.

A previsibilidade do dano também é um fator relevante para a common law quando se analisa a razoabilidade da atuação do credor. Tem-se como regra que não sendo previsível o prejuízo, não se pode exigir do credor um esforço de mitigação, haja vista que não se considera razoável um agir para aquilo que não se pode prever.

Do mesmo modo, o afastamento (remoteness) parece também ser crucial para a determinação da razoabilidade. Em cotejo com a previsibilidade, aquilo que não é previsível é remoto e, por isso, não atrai o duty to mitigate the $\operatorname{loss}^{48}$.

Em que pese ser possível extrair algumas balizas da razoabilidade exigida nos esforços do credor para mitigar seu dano, é reconhecida a insuficiência dos critérios adotados na common law. Por se tratar de uma análise puramente fática, é tormentosa a atividade do advogado de aconselhamento e previsão de uma decisão judicial em que há incidência da norma de mitigação. Assim como Bates ressalta, é difícil encontrar dois

47 BATES, Paul J. A Mitigation of Damages: A Matter of Commercial Common Sense. Advocate's Quarterly, v. 13, n. 3, p. 273-307, jan. 1992. p. 276.

${ }_{48}$ LITVINOFF, Saúl. Damages, Mitigation, and Good Faith. Tulane Law Review, New Orleans, v. 73, p. 1161-1195, 1999. p. 1170. Conforme salienta o autor, não se pode confundir, todavia, mitigação com a doutrina da previsibilidade e do afastamento do dano. Enquanto esta trata do momento da formação do contrato, aquela incide no momento do inadimplemento. Só esta diferença já é crucial para se compreender como institutos distintos na common law. 
casos concretos semelhantes que permita uma comparação. Citando trecho do caso James Street Hardware \& Furniture Co. v. Spizziri (1987), 62 O.R. (2d) 385, reforça que cada caso tem seus próprios fatos e que a Corte tende a não seguir um procedimento que ela diz ser desnecessariamente complicado ou montado por regras ${ }^{49}$.

Também é apontada a falta de desenvolvimento da norma de mitigação, nos detalhes que interessariam a sua aplicação, ocasionando em decisões judiciais que se orientam na verdade pelo próprio resultado. A conclusão do julgamento, se o esforço foi razoável ou não, é seguido pelos argumentos, e não o contrário, como se fosse um tudo ou nada $^{50}$. Define-se se a medida foi apta a mitigar o prejuízo, para só depois encontrar evidências de fato que corroboram tal conclusão, procedimento totalmente incoerente com a atividade jurisdicional.

Por vislumbrar tais problemas na common law é que se defende a aplicação da regra de aferição da razoabilidade no caso brasileiro a ser desenvolvida no Título II, Capítulo 4 deste estudo.

\subsubsection{Operações substitutivas como medida razoável}

Na common law é dada bastante ênfase às chamadas operações substitutivas (cover ou substitute transaction) como meios de efetivar o duty to mitigate the loss. Assim, como meio de evitar ou minimizar o prejuízo decorrente do inadimplemento, o credor realiza outras atividades, como a venda para terceiros dos bens, para depois cobrar da parte inadimplente as despesas que incorreu com o exercício da mitigação, além daqueles danos considerados inevitáveis. Desse modo, é aberta a possibilidade de o credor adotar medidas que incrementem a proteção de seu patrimônio envolvendo diretamente o objeto do contrato inadimplido em transações, não ficando restrito a medidas alternativas.

No desenvolvimento da doutrina das consequências evitáveis foi constatada a importância do mercado no ônus do credor de mitigar seu prejuízo por operações substitutivas. Para que elas possam ser realizadas, é preciso, em primeiro lugar, que o

\footnotetext{
49 BATES, Paul J. A Mitigation of Damages: A Matter of Commercial Common Sense. Advocate's Quarterly, v. 13, n. 3, p. 273-307, jan. 1992. p. 275-276.

${ }^{50}$ Idem, ibidem. p. 276.
} 
mercado exista ${ }^{51}$, já que não há como o credor se desincumbir de seu ônus através da operação substitutiva se não há interesse de terceiros pelo produto objeto do contrato inadimplido. E quanto mais especializado é o mercado, maior é a complexidade da operação, demandando mais variadas estratégias da parte interessada na mitigação ${ }^{52}$.

Nos Estados Unidos, o Uniform Commercial Code ${ }^{53}$ traz vários exemplos de operações substitutivas. Em nítida consonância com a CISG, a ser estudada adiante ${ }^{54}$, o Uniform Commercial Code traz operações substitutivas tanto para o vendedor quanto para o comprador. No tocante ao vendedor, as seguintes seções regulamentam as operações substitutivas:

$\S 2-706$. Revenda pelo vendedor, incluindo contrato para revenda

(1) Sob as condições estabelecidas na Seção 2-703 sobre os remédios à disposição do vendedor, o vendedor pode revender as mercadorias respectivas ou qualquer saldo não entregue. Quando a revenda é feita de boa-fé e de forma comercialmente razoável, o vendedor pode recuperar a diferença entre o preço de revenda e o preço contratual, além de quaisquer danos incidentais permitidos de acordo com os dispositivos desse Artigo (Seção 2-710), mas descontadas as despesas economizadas em razão do inadimplemento do comprador.

\section{$\S$ 2-708. Perdas e danos do vendedor pela não aceitação ou recusa}

(1) Sujeita à subseção (2) e aos dispositivos desse Artigo relativos à prova do preço de mercado (Seção 2-723), a medida dos danos pela não aceitação ou recusa pelo comprador é a diferença entre o preço de mercado no momento e lugar da entrega e o preço contratual não pago, acrescido de quaisquer danos incidentais permitidos de acordo com os dispositivos desse Artigo (Seção 2-710), mas descontadas as despesas economizadas em razão do inadimplemento do comprador.

(2) Se a medida de danos estabelecida na Subseção (1) é inadequada para colocar o vendedor em posição tão boa quanto o cumprimento teria feito, então a medida de danos é o lucro (incluindo as despesas gerais) que o vendedor teria auferido do integral cumprimento pelo comprador, acrescido de quaisquer danos incidentais permitidos de acordo com os dispositivos desse Artigo (Seção 2-710) e das despesas razoavelmente incorridas com a revenda, mas dando-se crédito pelos pagamentos ou valores obtidos com a revenda ${ }^{55}$.

\footnotetext{
${ }^{51}$ GOETZ, Charles J.; SCOTT, Robert E. The mitigation principle: toward a general theory of contractual obligation. Virginia Law Review. v. 69, p. 967-1024, setembro de 1983. p. 985.

${ }^{52}$ Idem, ibidem. p. 986-987.

53 Trata-se de código-modelo aprovado pelo Congresso estadunidense contendo diversos dispositivos regulamentando as transações comerciais. Foi adotado por todos os estados, salvo a Louisiana que excepcionou o artigo $2^{\circ}$, preferindo manter a sua própria legislação acerca da compra e venda de mercadorias.

${ }^{54}$ Vide Título III, Capítulo 6, item 6.5.

55 Tradução livre do original.
} 
A solução trazida pelo Uniform Commercial Code não difere daquela do artigo 75 da CISG. O vendedor, ao realizar a operação substitutiva, poderá ser indenizado pela diferença entre o valor de revenda e o preço originalmente estipulado no contrato inadimplido pelo comprador. Além disso, poderá recuperar quaisquer outras despesas que incorreu para realizá-la.

É adotada solução semelhante, mas não idêntica, no direito inglês. O artigo 50(3) do Sale of Goods Act define que no caso de recusa do comprador, o vendedor poderá cobrar a diferença entre o preço de mercado do momento em que o produto deveria ter sido aceito (ou quando foi realizada a recusa, se não havia prazo estipulado para a anuência) e o preço contratual. O paradigma, ao invés de ser revenda efetivamente realizada, é o preço de mercado abstratamente obtido. Assim, havendo mercado para a realização da operação substitutiva, o valor da indenização é obtido a partir da sua avaliação, independentemente do valor efetivamente alcançado com a revenda.

O $\S 2-708$, por sua vez, se aproxima do disposto no artigo 76 da CISG, estabelecendo que o valor a ser indenizado no caso de recusa do comprador é a diferença entre o preço de mercado no momento e lugar da entrega e o preço contratual. $O$ dispositivo, vale mencionar, vai além, pois define o lucro como medida dos danos caso seja inadequada a aplicação da diferença entre o preço de mercado no momento e lugar da entrega e o preço contratual.

No tocante ao comprador, o Uniform Commercial Code assim disciplina:

§ 2-712. Operação substitutiva; aquisição pelo comprador de mercadorias substitutas

(1) Depois do inadimplemento na forma da seção precedente, o comprador pode efetivar operação substitutiva, desde que, de boa-fé e sem atrasos indevidos, efetive razoavelmente a compra ou um contrato de compra de mercadorias em substituição daquelas devidas pelo vendedor.

(2) O comprador pode recuperar do vendedor como perdas e danos a diferença entre o custo da operação substitutiva e o preço contratual, além de quaisquer danos incidentais ou consequenciais conforme definidos a seguir (Seção 2-715), mas descontadas as despesas economizadas em razão do inadimplemento do vendedor.

(3) A abstenção do comprador em realizar a operação substitutiva nos termos dessa seção não o impede de obter qualquer outro remédio.

$\S 2-713$. Perdas e danos do comprador pela falta de entrega ou recusa

(1) Sujeita aos dispositivos desse Artigo relativos à prova do preço de mercado (Seção 2-723), a medida das perdas e danos pela falta de entrega ou recusa pelo 
vendedor é a diferença entre o preço do mercado no momento que o comprador tomou conhecimento do inadimplemento e o preço contratual, além de quaisquer danos incidentais ou consequenciais conforme definidos a seguir (Seção 2-715), mas descontadas as despesas economizadas em razão do inadimplemento do vendedor.

(2) O preço de mercado é determinado no lugar da entrega ou, em casos de rejeição depois do recebimento ou de revogação da aceitação, no local do recebimento ${ }^{56}$.

Os direitos do comprador na operação substitutiva são semelhantes àqueles do vendedor. Poderá o comprador buscar no mercado as mercadorias que desejava, mas inadimplidas pelo vendedor. Do mesmo jeito, será feito o cálculo da diferença entre o custo da medida e o preço contratado originalmente para determinar o valor das perdas e danos. No tocante à falta de entrega ou recusa do vendedor em vender as mercadorias objeto do contrato de compra e venda, o comprador poderá buscá-las no mercado, cobrando depois do vendedor a diferença entre o preço do mercado no momento que o comprador ficou ciente do inadimplemento, determinado pelo lugar da entrega (ou do recebimento, conforme o caso), e o preço contratado. Em todos os casos, ainda incidem os chamados danos incidentais e consequenciais ${ }^{57}$.

Da mesma maneira como funciona no caso do vendedor, a diferença no valor a ser obtido a título de indenização pelo comprador é calculado de forma abstrata no direito inglês. O artigo 51 do Sale of Goods Act define que, caso haja mercado, o valor da indenização é obtido pela diferença entre o valor originalmente contratado e o preço corrente das mercadorias no momento em que deveriam ter sido entregues ou o vendedor se recusou a entregá-las.

Por fim, é importante ressaltar que o Uniform Commercial Code também faz referência a uma operação substitutiva quando as mercadorias ainda não estão completas e já há uma quebra no vínculo contratual por culpa do comprador. Nestes casos, aplica-se o $\S$ 2-704:

$\S 2$-704. Direito do vendedor de atribuir mercadorias ao contrato apesar do inadimplemento ou de recuperar por mercadorias inacabadas.

$[\ldots]$

(2) Quando as mercadorias estiverem inacabadas, o vendedor prejudicado pode, no exercício de seu julgamento empresarial razoável, com o objetivo de evitar

\footnotetext{
${ }^{56}$ Idem.

${ }^{57}$ Vide item 1.2.5. infra.
} 
perda e sua efetiva realização, tanto completar a manufatura e atribuir as mercadorias ao contrato como cessar a manufatura e revender pelo valor de sucata ou bens recuperados, bem como proceder de qualquer outra maneira razoável $^{58}$.

O vendedor não precisa necessariamente completar a sua atividade se sabe que já houve (ou haverá) uma violação contratual. Por vezes, em razão da especificidade da mercadoria manufaturada, terminá-la impede que seja revendida no mercado. Assim, torna-se medida razoável, em consonância com a mitigação, o vendedor interromper a sua atividade e buscar uma alternativa para impedir seu prejuízo.

\subsection{Celebração de um novo contrato como operação substitutiva}

Uma das medidas bastante discutidas no âmbito da common law é a possibilidade de o credor celebrar um novo contrato com o devedor para, dessa forma, mitigar o prejuízo relativo ao contrato em que ocorreu o inadimplemento. Na hipótese, o devedor oferece a realização da prestação original ou cumulada com prestações adicionais, surgindo para o credor uma alternativa para evitar ou minimizar o dano ${ }^{59}$. E a sua aceitação ou rejeição pode ser decisiva na aplicação da regra das consequências evitáveis pelo magistrado.

Conforme Hillman ${ }^{60}$ são três categorias que a Corte analisa na aplicação da regra: as razões para o inadimplemento original, a posição da parte prejudicada após o inadimplemento e os termos da oferta substitutiva. As razões podem ser voluntárias ou inevitáveis, sendo que as primeiras têm motivos estratégicos - como a expectativa de conseguir melhores condições no negócio - e as segundas situações além do controle da parte. Quanto à posição, leva-se em consideração o vexame ou humilhação que a parte prejudicada pode se submeter ao aceitar negociar com a parte inadimplente, a extensão do prejuízo, se a oferta substitutiva mitigará o prejuízo e até que ponto a parte prejudicada poderia aceitar o novo pacto. Por fim, a análise da categoria dos termos da oferta substitutiva inclui a verificação da renúncia de direitos derivados do inadimplemento, se os

\footnotetext{
${ }^{58}$ Tradução livre do original.

${ }^{59}$ GOETZ, Charles J.; SCOTT, Robert E. The mitigation principle: toward a general theory of contractual obligation. Virginia Law Review. v. 69, p. 967-1024, setembro de 1983. p. 983.

${ }^{60}$ HILLMAN, Robert A. Keeping the Deal Together After Material Breach: Common Law Mitigation Rules, the UCC, and the Restatement (Second) of Contracts. University of Colorado Law Review. v. 47, p. 553-615, 1976. p. 598.
} 
termos são idênticos ou mais onerosos, se a oferta contém os melhores termos disponíveis para a parte prejudicada e se há alguma garantia que o devedor irá cumprir o pactuado.

O autor então formula modelos de questões que auxiliam na verificação da incidência da regra das consequências evitáveis no caso concreto. Se todas as respostas forem afirmativas, a celebração de um novo contrato com o devedor se mostra uma medida razoável para a mitigação do dano. São elas:

\footnotetext{
1. Pode a aceitação da nova oferta reduzir os prejuízos?

2. Pode a parte prejudicada aceitar a nova oferta?

3. É a nova oferta da parte inadimplente a melhor disponível?

4. É a parte prejudicada livre para buscar seus direitos sobre o contrato original mesmo aceitando a nova oferta?

5. Pode a parte inadimplente providenciar garantia adequada que cumprirá sua obrigação? ${ }^{11}$
}

Conforme será visto no Capítulo 4, a série de questionamentos desenvolvida por Hillman não deixa de ser um desdobramento específico daqueles que serão utilizados para nossa regra de aferição da razoabilidade. A diferença consiste na generalidade/especificidade dos procedimentos, já que a ideia de Hillman é válida para o âmbito do direito contratual, ramo em que há maior desenvolvimento do duty to mitigate the loss na common law. E para uma situação específica: a oferta de um novo contrato pelo devedor como medida razoável de mitigação do prejuízo. Por outro lado, a regra de aferição da razoabilidade proposta por nós está num grau acima, de maior generalidade, aplicável tanto ao direito contratual quanto ao extracontratual. As regras são, por isso, compatíveis, mas de desnecessária concomitância de aplicação ${ }^{62}$.

Também foram identificadas por Hillman as situações mais comuns encontradas nos tribunais as quais, embora o credor tenha negado a nova oferta, agiu de acordo com a regra das consequências evitáveis. Elas são: o contrato original era de enorme natureza pessoal, a oferta incluía novos ou modificados termos, a nova oferta exigia a renúncia de

\footnotetext{
${ }^{61}$ Idem, ibidem. p. 599. (tradução livre do original)

${ }^{62}$ Consoante o que será exposto adiante no Capítulo 4, as duas primeiras questões dizem respeito ao quesito da adequação, pois se a nova oferta não puder reduzir os prejuízos ou a própria parte prejudicada não puder com ela consentir, logo a oferta é uma medida inadequada. As três questões restantes se encaixam na verificação da onerosidade e periculosidade, pois se não for a melhor disponível, se prejudicar direitos ou incrementar o prejuízo, logo são medidas que são onerosas ou perigosas.
} 
direitos oriundos do contrato original e o inadimplemento original macula nova oferta pelo devedor ${ }^{63}$.

O primeiro caso é exemplificado através do contrato de emprego, em situação que o empregador faz nova oferta de emprego para aquele que havia sido demitido sem justa causa. Aceitar o novo emprego, ainda que em condições iguais ao do anterior, seria vexatória para o empregado, por ter que lidar com o empregador que não teve escrúpulos de não prejudicá-lo.

O segundo caso diz respeito ao entendimento de algumas Cortes que a oferta deve ser idêntica à anterior, não podendo haver modificações ou termos novos. Se existirem, então a parte prejudicada não está obrigada a aceitar a oferta, pois não se trata de uma medida razoável para a mitigação. Conforme destaca Lopes ${ }^{64}$, a hipótese não é pacífica na jurisprudência, haja vista que mesmo uma oferta menos favorável à parte prejudicada pode se mostrar, no fim, medida razoável:

\begin{abstract}
O caso de um viticultor da Califórnia é referido por praticamente todos que tratam dessa matéria. $\mathrm{O}$ viticultor contratou o fornecimento de água junto a uma empresa de irrigação por $\$ 58$, que deveriam ser pagos em $1^{\circ}$ de setembro. A empresa, entretanto, requereu o pagamento antecipado em duas prestações iguais, vencendo-se em $1^{\circ}$ de fevereiro e $1^{\circ}$ de julho, justificando sua solicitação em uma regra da autoridade regulatória. $\mathrm{O}$ viticultor recusou essa demanda, a empresa cortou a água e toda a safra foi perdida, resultando em prejuízos de milhares de dólares. A Corte considerou que o custo da mitigação seria apenas de $\$ 1,53$, representado pelos juros devidos pelo adiantamento do pagamento, e que tal valor seria insignificante diante do que poderia ter sido evitado. Negou, assim, a indenização pelos prejuízos com a perda da safra.
\end{abstract}

O terceiro caso é aquele em que os tribunais não consideram uma medida razoável para mitigar o prejuízo se a oferta realizada pela parte inadimplente acarreta na renúncia de direitos inerentes ao inadimplemento do contrato original. Não lhes pareceu lícito exigir da parte prejudicada a renúncia ao direito de indenização pelos prejuízos como uma medida de mitigação.

Por fim, o quarto caso trazido por Hillman consiste na falta de segurança transmitida pela parte de ofertar um novo acordo, sendo que já fora inadimplente no

\footnotetext{
${ }^{63}$ HILLMAN, Robert A. Keeping the Deal Together After Material Breach: Common Law Mitigation Rules, the UCC, and the Restatement (Second) of Contracts. University of Colorado Law Review. v. 47, p. 553-615, 1976. p. 569-570.

${ }^{64}$ LOPES, Christian Sahb Batista. A mitigação dos prejuízos no direito contratual. Belo Horizonte, 2011. Tese (Doutorado em Direito). Faculdade de Direito da Universidade Federal de Minas Gerais. p. 46-47.
} 
contrato original. As Cortes entenderam que a parte inadimplente deixou de transmitir credibilidade à parte prejudicada e, por isso, ela não pode ser obrigada a confiar naquele que já deu motivos para prever que não honrará com seus compromissos.

Portanto, a celebração de um novo contrato com o devedor pode ser uma alternativa de medida razoável para mitigação do prejuízo. Contudo, tendo em vista ser uma operação de alto risco para o credor por conta do inadimplemento original, é preciso que tome as devidas cautelas antes de aceitar o novo pacto. Mais ainda, que seja realizada uma análise criteriosa tanto pelo credor quando está diante de uma situação como esta, quanto pelo magistrado, verificando se é realmente um meio viável para evitar ou reduzir o prejuízo.

\subsubsection{Insuficiência de recursos financeiros e medida razoável}

O problema da insuficiência de recursos financeiros (impecuniosity issue) do credor para adotar medidas razoáveis para mitigar o prejuízo também é enfrentado nos países de common law. A mitigação requer uma postura do credor para evitar o prejuízo, e isto demanda tempo, dinheiro e esforço ${ }^{65}$. No entanto, é possível que o credor careça de recursos financeiros para a realização das medidas razoáveis e é preciso saber se isto é um paradigma absoluto para afastar o ônus de mitigação. Afinal, não dispondo o credor de recursos economicamente apreciáveis, o prejuízo sofrido seria inevitável. E não se pode exigir do credor que cumpra sua incumbência com sacrifício próprio, além de suas possibilidades, haja vista que a mitigação não presume recursos financeiros infinitos do credor $^{66}$.

O caso canadense Dawson v. Helicopter Explorations Co. Ltd. (1958), 12 D.L.R. (2d) 1 (S.C.C.) é citado algumas vezes como precedente para a solução do problema, argumentando que a insuficiência financeira não é motivo para a inobservância da mitigação. Dawson propôs a ação em razão da quebra contratual do réu, que ao invés de vender suas ações ao autor, fez negócio com terceiro, vendendo setenta e cinco mil ações para este. Pouco tempo depois, dois dos compradores revenderam vinte mil ações pelo preço de \$1.10. Dawson, então, requereu a possibilidade de escolher entre o valor vendido

\footnotetext{
65 BATES, Paul J. A Mitigation of Damages: A Matter of Commercial Common Sense. Advocate's Quarterly, v. 13, n. 3, p. 273-307, jan. 1992. p. 291.

${ }^{66}$ Idem, ibidem.
} 
(\$1.10) ou do momento do julgamento (\$5.85). O seu pedido foi rejeitado, consignando a decisão que o valor de $\$ 1.10$ é a evidência dos valores que Dawson receberia pelas ações.

Em nenhum momento foi alegada a insuficiência de recursos financeiros ou a questão da mitigação pelas partes. Contudo, uma manifestação do juiz Rand no julgamento criou o precedente, afirmando que não seria um argumento válido Dawson dizer que não adquiriu as ações na bolsa de valores porque no momento não tinha recursos suficientes para comprá-las. O comentário foi desnecessário para a conclusão do julgamento e, a bem da verdade, não deveria ser citado como precedente, não vinculando as Cortes canadenses a segui-1o ${ }^{67}$.

Um melhor precedente para o desenvolvimento do tema é o caso "Liesbosch" (The), [1933] A.C. 449 (H.L). Nele, o Lorde Wright traçou importante distinção acerca do momento em que o credor se tornou financeiramente hipossuficiente. O autor poderá ter recursos financeiros insuficientes antes da celebração do contrato ou se tornar hipossuficiente por causa do inadimplemento contratual. $\mathrm{Na}$ opinião do julgador, o problema se resolve através da causalidade e não da norma de mitigação, pois o inadimplemento do devedor pode ter contribuído ou não para a situação crítica do credor, ou seja, pode ou não ser a sua causa. O devedor, então, terá que realizar a difícil prova de que com ou sem o seu inadimplemento, o credor estaria na mesma situação ${ }^{68}$.

Determinante, contudo, foi o entendimento apresentado no caso Hadley $v$. Baxendale (1854), 9 Ex. 341, 156 E.R. 145. Hadley trabalhava no ramo alimentício, especificamente com grãos e, para tanto, utilizava-se de maquinário próprio. Certo dia, a cambota de uma das máquinas a vapor quebrou, fazendo com que Hadley contratasse um terceiro para fazer uma nova. O contratado, contudo, afirmou que não poderia fazer a nova cambota sem ver a antiga quebrada, pois correria o risco de a nova não se encaixar adequadamente na máquina a vapor. Hadley, então, contratou Baxendale para fazer o serviço de entrega da peça quebrada. No entanto, Baxendale não entregou a peça na data marcada, fazendo com que Hadley tivesse perdas em seu negócio. Hadley, então, processou Baxendale cobrando os valores que deixou de lucrar.

Após ser condenado pela primeira instância, Baxendale apelou alegando que não tinha como saber que Hadley teria perdas desta magnitude pelo atraso na entrega da cambota e, por isso, não poderia ser responsabilizado. A Corte, então, concordou com seus

\footnotetext{
${ }^{67}$ Idem, ibidem. p. 292-293.
}

${ }^{68}$ Idem, ibidem. p. 294. 
argumentos, desautorizando Hadley de receber os valores pleiteados, afirmando ainda que os prejuízos havidos não eram previsíveis e o autor em momento algum informou desta possibilidade o réu.

O precedente, embora não seguido pelo Judiciário canadense ${ }^{69}$, foi seguido pelas Cortes inglesas. Firmou-se o entendimento que o argumento da insuficiência de recursos financeiros só poderá ser utilizado quando o credor informa o devedor da sua hipossuficiência ou da possibilidade de assim se tornar caso haja o inadimplemento contratual $^{70}$.

Em que pese o entendimento inglês, não parece ser a melhor solução para o caso brasileiro. Consoante será exposto adiante ${ }^{71}$, a insuficiência de recursos financeiros será aqui trazida como uma das características que excluem a necessidade de o credor adotar qualquer medida considerada razoável, tendo em vista que se desdobraria em um sacrifício desnecessário, tornando a medida excessivamente onerosa. Seja a hipossuficiência preexistente ou causada pelo inadimplemento, o credor só não adotou uma medida razoável para mitigar seu prejuízo por sua causa. Não se pode dizer que foi uma atitude contrária ao princípio da boa-fé, porque nessa hipótese o credor não tinha outra opção. $\mathrm{O}$ devedor é quem deu razão à inadimplência e, por isso, terá que arcar com as consequências da inobservância de suas obrigações.

\subsubsection{Reputação e medida razoável}

Na common law o credor não terá o ônus de mitigar caso a medida viole a sua reputação no mercado. Isto porque os prejuízos decorrentes desta violação serão muito maiores do que o dano decorrente do inadimplemento.

O caso Banco de Portugal v. Waterlow \& Sons Ltd [1932] A.C. 452 (H.L.) explicita bem esta questão. O Banco de Portugal contratou a Waterlow para emitir cédulas para por em circulação em Portugal. Após uma quantidade significativa já terem sido impressas, uma falha de segurança da Waterlow permitiu que um indivíduo imprimisse notas falsas e as pusesse em circulação. Ao descobrir a falha e a falsidade, o Banco de Portugal permitiu

\footnotetext{
${ }^{69}$ Idem, ibidem. p. 295.

${ }^{70}$ GOETZ, Charles J.; SCOTT, Robert E. The mitigation principle: toward a general theory of contractual obligation. Virginia Law Review. v. 69, p. 967-1024, setembro de 1983. p. 1015.

${ }^{71}$ Vide Título II, Capítulo 4, item 4.2.1. infra.
} 
que os detentores das cédulas impressas pela Waterlow as trocassem por outras em sua sede, emitidas por suas expensas. O Banco de Portugal, então, processou a Waterlow, cobrando os valores que teve que gastar na medida do valor escrito nas notas trocadas. A Corte deu razão ao Banco de Portugal, constatando que a sua preocupação com o mercado, impedindo o abalo econômico e comercial do país, foi determinante para resolver a situação. Assim, mesmo tendo um gasto excessivo, o Banco de Portugal o fez para resguardar a sua reputação.

A reputação do credor é importante aspecto a ser considerado na aferição da razoabilidade da medida a ser adotada. Na alegação pelo devedor de que o credor tinha o ônus de mitigar seu prejuízo, o credor terá que demonstrar o risco das adversidades financeiras que poderia acarretar se procedesse conforme a norma de mitigação. Não se pode esperar que o credor incorra em prejuízos em um longo prazo para evitar ou minimizar prejuízos a curto prazo $^{72}$.

\subsection{4. Ônus da prova}

Em relação ao ônus da prova, o devedor tem que provar que o credor não tomou as medidas razoáveis para mitigar os prejuízos considerados evitáveis ${ }^{73}$. Esta distribuição do ônus probatório decorre tanto da leitura do $\$ 347$ do Restatement (Second) of Contracts quanto do artigo 2002 do Código Civil da Louisiana, este último aplicável somente àqueles submetidos à jurisdição do Estado da Louisiana.

$\mathrm{Kerr}^{74}$ faz referência a diversos julgados em que o ônus da prova foi reconhecido pelos tribunais como sendo do devedor. Todavia, aponta que tal incumbência fora reconhecido como limitada à prova da inobservância pelo credor da norma de mitigação, e não de quais prejuízos especificamente este deixou de evitar ou minimizar. Esta última medida cabe ao próprio credor, em razão da superação da prova inicialmente produzida por este ao pleitear a indenização. A solução não é diversa daquela que será apontada para o caso brasileiro.

\footnotetext{
72 BATES, Paul J. A Mitigation of Damages: A Matter of Commercial Common Sense. Advocate's Quarterly, v. 13, n. 3, p. 273-307, jan. 1992. p. 282.

${ }^{73}$ LITVINOFF, Saúl. Damages, Mitigation, and Good Faith. Tulane Law Review, New Orleans, v. 73, p. 1161-1195, 1999. p. 1189.

${ }^{74}$ KERR, A. J. Mitigation of loss: Problems Concerning the Onus of Proof. South African Law Journal. v. 98, p. 306-307, 1981.
} 
Uma diferença que se pode apontar entre a solução dada pela common law e a legislação brasileira é a questão da limitação derivada da evitabilidade do prejuízo. Na common law, a indenização é limitada porque a responsabilidade é igualmente limitada. Entende-se que existe responsabilidade do devedor pelos prejuízos, até que este alegue a inobservância do credor de mitigar os danos considerados evitáveis. Só a partir desta alegação é que haverá uma limitação da responsabilidade, reduzindo - ou até eliminando o quantum indenizatório devido.

Já no caso brasileiro, consoante será visto adiante ${ }^{75}$, a inobservância do duty to mitigate the loss não faz nascer para o devedor qualquer responsabilidade pelos danos evitáveis que poderiam ter sido mitigados. Ainda que seja ônus do devedor de provar a inobservância da norma de mitigação, o juiz poderá de ofício reconhecer tal fato e não conceder a indenização no valor pleiteado pelo credor. Não é porque o devedor falhou no seu ônus probatório e que uma indevida indenização foi concedida que significa ter a ela direito o credor. Houve uma falsa leitura da realidade, tornada definitiva pelo Poder Judiciário por razões de segurança jurídica apenas.

\subsubsection{Prejuízos incidentais e consequenciais}

A common law faz distinção dos prejuízos, classificando-os entre incidentais e consequenciais. Os prejuízos incidentais, de acordo com os comentários do $§ 347$ do Restatement (Second) of Contracts, são os custos que a parte incorreu razoavelmente na tentativa de, com sucesso ou não, evitar o dano, assim como ocorre quando a parte realiza gastos para tentar realizar uma operação substitutiva. Os prejuízos consequenciais, por sua vez, são os danos pessoais e patrimoniais sofridos em razão do inadimplemento da outra parte.

Na operacionalização da norma de mitigação, a mensuração dos prejuízos, consoante o Restatement (Second) of Contracts deve observar os seguintes requisitos:

\section{$\S 347$. Medida das perdas e danos em geral}

Sujeito às limitações previstas nos $\S \S 350-53$, a parte prejudicada tem direito às perdas e danos baseadas no seu interesse de expectativa, medidas por

\footnotetext{
${ }^{75}$ Conforme Título II, Capítulo 3, item 3.3.
} 
(a) a perda no valor para ela da prestação da outra parte causada por sua falha ou deficiência, mais

(b) qualquer outra perda, incluindo perdas incidentais ou consequenciais causadas pelo inadimplemento, menos

(c) qualquer custo ou outra perda que tenha sido evitado por não ter que $\operatorname{prestar}^{76}$.

Especificando a regra para o comércio, o Uniform Commercial Code traz também dispositivos que determinam os prejuízos consequenciais e incidentais que podem ser exigidos. O que muda é o tratamento diferenciado que traz para o vendedor e comprador. Para o vendedor, é previsto somente o ressarcimento pelos prejuízos incidentais:

\section{§ 2-710. Prejuízos incidentais do vendedor}

Danos incidentais a um vendedor lesado incluem quaisquer encargos, despesas ou comissões comercialmente razoáveis incorridas para suspender a entrega, no transporte, guarda e custódia dos bens após o inadimplemento do comprador, em conexão com o retorno ou revenda de bens ou de outra forma resultantes do inadimplemento ${ }^{77}$.

Já para o comprador, o ressarcimento tanto pelos prejuízos incidentais quanto consequenciais possuem previsão:

$\S$ 2-715. Prejuízos incidentais e consequenciais do comprador.

(1) Prejuízos incidentais resultantes do inadimplemento do vendedor incluem despesas razoavelmente incorridas com a inspeção, recebimento, transporte e cuidado e custódia dos bens legitimamente rejeitados, qualquer encargo comercialmente razoável, despesas ou comissões em conexão com o efeito de cobertura e qualquer outra despesa incidente razoável pelo atraso ou outro inadimplemento.

(2) Prejuízos consequenciais resultantes do inadimplemento do vendedor incluem

(a) Qualquer perda resultante de requerimentos ou necessidades gerais ou particulares as quais o vendedor no momento da contratação tinha como saber e que não poderia razoavelmente prevenir por cobertura ou outro meio; e

(b) Lesão à pessoa ou ao patrimônio resultando em qualquer violação da garantia $^{78}$.

\footnotetext{
${ }^{76}$ Tradução livre do original.

77 Idem.

${ }^{78}$ Idem.
} 


\subsubsection{Cláusula de danos liquidados}

As cláusulas de danos liquidados (liquidated damages clause) são o equivalente às cláusulas penais do direito pátrio ${ }^{79}$. Tratam de antecipadamente estipular o valor da indenização no caso de uma das partes não adimplir com a sua obrigação. São normalmente pactuadas quando o prejuízo é incerto, principalmente quando não há mercado para o objeto do contrato ou valor satisfatório para medir as perdas com o inadimplemento.

Nos Estados Unidos, o Uniform Commercial Code trata do instituto na Seção 2718(1):

§ 2-718. Liquidação ou Limitação dos Prejuízos; Depósitos.

(1) Prejuízos pelo inadimplemento por qualquer parte pode ser liquidada no acordo, mas apenas em um montante que é razoável à luz do atual ou antecipado dano causado pelo inadimplemento, às dificuldades de prova da perda, e à inconveniência ou inviabilidade de obter outro remédio adequado. Um termo fixando uma não razoavelmente alta liquidação de prejuízos é nula como uma pena $^{80}$.

O §356(1) do Restatement (Second) of Contracts segue a mesma orientação, com alterações mínimas em sua redação. Ambos os diplomas tratam apenas dos aspectos gerais da cláusula, sem aprofundar nas dificuldades que uma estipulação equivocada - sem ser de forma não razoável, mas por plena imprevisibilidade das partes quanto às consequências gravosas - pode criar numa situação fática. No direito brasileiro, por exemplo, é possível que o juiz reduza equitativamente a penalidade no caso de cumprimento parcial da obrigação, enquanto que na common law esta disposição não está presente.

A cláusula de danos liquidados é tratada na common law somente pelo aspecto da razoabilidade do valor estipulado quando em cotejo com as condições que estabelece. Se não atender a referidos limites, a cláusula é considerada nula. Os próprios comentários que acompanham o §356(1) do Restatement (Second) of Contracts evidenciam esta preocupação exclusiva da common law, dando maior ênfase à aproximação do valor estipulado e do dano realmente experimentado, dependendo da dificuldade de prova. Se

\footnotetext{
${ }^{79}$ Sobre a mitigação e cláusula penal no direito brasileiro, vide Título II, Capítulo 2, item 2.3.1.

${ }^{80}$ Tradução livre do original.
} 
existia grande dificuldade de provar qual seria um valor adequado para a indenização, admite-se um distanciamento maior entre os valores pactuados e do dano. Se pequena a dificuldade, o distanciamento deve ser menor. Sendo tais parâmetros descumpridos, a cláusula é tida como nula. Há, portanto, uma visão um tanto quanto restritiva, com a possibilidade de validade ou não da cláusula.

Em razão da falta de parâmetros para relativização da cláusula de danos liquidados, as Cortes têm lhe dado prevalência sobre a norma de mitigação. No caso NPS, LLC v. Minihanne, 886 N.E.2d 670, 675 (Mass. 2008) trazido por Fortin ${ }^{81}$, John Minihanne havia celebrado um termo de licença com a NPS, LLC para dois assentos no Gillette Stadium, estádio do time de futebol americano New England Patriots. No termo, havia uma cláusula de danos liquidados que permitia a NPS, LLC cobrar antecipadamente os valores devidos no caso de inadimplemento. Minihanne assistiu a todos os jogos da temporada de 2002, menos um, mas pagou apenas duas parcelas do termo de licença. A NPS, LLC, então, propôs ação com base na cláusula de danos liquidados. A discussão se pautou pelo montante dos prejuízos havidos e a validade da cláusula. A Suprema Corte de Massachusetts entendeu que não incide a norma de mitigação quando pactuada uma cláusula de danos liquidados, "seguindo a regra de muitas outras jurisdições".

Se o fato ocorresse dentro da jurisdição brasileira, haveria a possibilidade de redução do valor devido estipulado na cláusula penal pelo adimplemento de ao menos duas parcelas pelo devedor. Contudo, como a common law não desenvolveu entendimento neste sentido, o valor devido é o total.

Fortin critica duramente esse posicionamento, tendo em vista que afeta a eficiência da doutrina das consequências evitáveis, causa o enriquecimento ilícito pelo lucro duplo e penaliza indevidamente o devedor ${ }^{82}$. E arremata que as Cortes estadunidenses parecem querer buscar a solução mais fácil que é não reconhecer o duty to mitigate the loss quando existe a cláusula de danos liquidados, para que não seja necessário fazer cálculos, por vezes difíceis, para aferição do valor dos prejuízos ${ }^{83}$.

Assim, como regra geral, a common law adota o mesmo posicionamento do direito pátrio ao negar a incidência da norma de mitigação quando existe uma cláusula de danos

\footnotetext{
${ }^{81}$ FORTIN, Lisa A. Why There Should Be a Duty to Mitigate Liquidated Damages Clauses. Hofstra Law Review. v. 38, p. 285-318, 2009-2010. p. 285-286.

${ }^{82}$ Idem, ibidem. p. 286.

${ }^{83}$ Idem, ibidem. p. 317-318.
} 
liquidados/cláusula penal. Entretanto, difere na questão da relativização de sua cobrança conforme o caso concreto, tendo em vista a postura das partes.

\subsubsection{Jurisprudência do duty to mitigate the loss na common law}

Além dos casos já mencionados contextualmente neste estudo, abaixo serão colacionados outros em que as cortes estadunidenses e britânicas também aplicaram o duty to mitigate the loss em suas decisões. Para tanto, foram selecionados casos bastante distintos para que seja compreendida a amplitude de incidência do instituto na common law.

\subsubsection{Estados Unidos}

No primeiro caso $^{84}$, a autora, a atriz Shirley Maclaine Parker, celebrou contrato com o estúdio Fox para estrelar em um filme no formato de um musical chamado "Bloomer Girl". Contudo, pouco antes da data marcada para o início das produções, o filme foi cancelado. $\mathrm{O}$ estúdio, devendo setecentos e cinquenta mil dólares para a atriz, ofereceu escalá-la em outro projeto com a mesma remuneração. O problema é que as filmagens não iriam acontecer nos Estados Unidos, e sim, na Austrália, além de ser um filme de faroeste. Não aceitando o papel, a atriz pleiteou perdas e danos.

O estúdio Fox argumentou que, ao não aceitar o papel no segundo filme, a atriz teria falhado em mitigar o seu prejuízo e, por isso, não teria direito a qualquer pagamento pelo contrato original. A Suprema Corte da Califórnia, no entanto, discordou da tese. Afirmou que os papéis eram muito diferentes, não podendo ser comparáveis a ponto de se mostrar uma alternativa viável. Assim, a atriz não estava obrigada a aceitar o segundo papel.

Outra aplicação interessante do duty to mitigate the loss é encontrada na jurisprudência estadunidense tratando de relação de trabalho ${ }^{85}$. O autor da ação trabalhava

\footnotetext{
${ }^{84}$ ESTADOS UNIDOS. Parker v. Twentieth Century-Fox Film Corp., 474 P.2d 689 (Cal. 1970). Disponível em: http://law.justia.com/cases/california/cal3d/3/176.html. Acesso em 20/02/2014.

${ }^{85}$ ESTADOS UNIDOS. Moore v. University of Notre Dame, 22 F. Supp. 2d 896, 906-07 (N.D. Ind. 1998). Disponível em: http://www.leagle.com/decision/199891822FSupp2d896_1813. Acesso em 20/02/2014.
} 
para a Universidade de Notre Dame quando, em razão de discriminação por sua idade (62 anos), foi demitido. A demissão foi conturbada a ponto de o autor não mais conseguir conversar com o seu antigo supervisor. A Universidade de Notre Dame, então, propôs ao autor a sua recontratação em outro emprego, mas com remuneração menor. Dada a situação desconfortável e os termos da proposta de trabalho, o autor a rejeitou e começou a trabalhar em outros três empregos. Ainda assim, não deixou de propor ação indenizatória contra a Universidade de Notre Dame, pleiteando montante pelos danos sofridos.

A Corte entendeu que o autor adotou medidas razoáveis para mitigar seu dano, já que demonstrou estar comprometido em encontrar um novo emprego. Tanto que pouco tempo depois já trabalhava em três lugares distintos. $O$ fato de não aceitar a proposta da Universidade Notre Dame e nem se candidatar a outras vagas não mostra uma falha na observância do duty to mitigate the loss. Além disso, deve-se levar em conta a idade avançada do autor (que na época do julgamento tinha 66 anos), a qual dificulta a sua recolocação no mercado de trabalho, principalmente no quesito de ser um trabalho comparável (comparable work), isto é, aquele, virtualmente, de idênticas oportunidades de promoção, compensação, responsabilidades, condições de trabalho e status.

Outro caso que também merece menção ${ }^{86}$. Em 28 de abril de 2001 o autor foi envolvido em um acidente automobilístico, ocorrido por culpa do motorista do outro veículo que colidiu com o do autor. Por causa do acidente, o autor começou a sentir dores no pé direito. À época, o problema foi tratado com os medicamentos adequados para o caso. Algum tempo depois, o autor, para diminuir a pressão ao caminhar, começou a entortar o pé direito para fora, mostrando que o seu problema ainda não tinha sido resolvido. A partir de janeiro de 2002, o autor começou um tratamento com outro médico, descobrindo que o problema não era apenas no pé direito, mas neurológico também. A solução adequada ao caso seria uma cirurgia a qual o autor não se submeteu, fato que foi levantado pela seguradora, ré da ação indenizatória proposta pelo autor.

A Corte decidiu que para incidir o duty to mitigate the loss, isto é, ser razoável o autor se submeter a uma cirurgia, é preciso a verificação de quatro fatores: a probabilidade de a cirurgia ser bem sucedida para corrigir ou melhorar a situação do operado, o risco envolvido, a dor e a inconveniência causada pela cirurgia e a possibilidade de o autor arcar

\footnotetext{
${ }^{86}$ ESTADOS UNIDOS. Simmons v. Erie Ins. Exch., 891 N.E.2d 1059, 1067 (Ind. Ct. App. 2008). Disponível em: http://www.leagle.com/decision/In\%20INCO\%2020080811097. Acesso em 20/02/2014.
} 
com as custas do procedimento. O caso não teve uma decisão definitiva, precisando de novo julgamento em razão de error in procedendo.

\subsubsection{Inglaterra e País de Gales}

Um inquilino comercial desocupou o imóvel locado antes do término do prazo fixado do contrato de locação, o qual não possuía nenhuma cláusula de rescisão ${ }^{87}$. Consequentemente, deixou de pagar os valores referentes ao período em que o imóvel ficou desocupado. Discordando da postura do locatário, o proprietário do imóvel propôs demanda na tentativa de recuperar a renda total para o restante do contrato de locação. Aquele, por sua vez, argumentou que o proprietário tinha que observar o duty to mitigate the loss buscando novo locatário, limitando as perdas para a quantidade de tempo que as instalações permaneceram vagas. O Tribunal de Apelação não acatou esta tese afirmando que, nas circunstâncias do caso, era razoável para o proprietário insistir em pagamento integral do aluguel, já que havia outras opções abertas para o inquilino, como encontrar um cessionário disposto a reduzir a sua exposição.

Outra situação distinta ${ }^{88}$. Bulkhaul trabalha com a locação de tanques para transporte de produtos químicos e a Rhodia desenvolve tais produtos. Em 1999 a Bulkhaul celebrou contrato de locação com a Rhodia, fornecendo 18 tanques para transporte de ácido fluorídrico por dez anos por um preço fixo diário. Em outubro de 2004, próximo à metade do prazo contratual, a Rhodia parou de produzir ácido fluorídrico e, consequentemente, não precisava mais dos tanques alugados, decidindo rescindir o contrato. A Bulkhaul, contudo, entendeu que o contrato não podia ser encerrado antes do termo final por aviso em tempo razoável da Rhodia e resolveu propor ação indenizatória. Nela, a Bulkhaul cobrou os valores que teria direito se o contrato continuasse em vigor até o termo final.

A discussão do caso pode ser resumida em dois pontos. O primeiro deles diz respeito à extensão da redução do dano a qual a Bulkhaul estava obrigada a realizar. $\mathrm{O}$ segundo, se a Bulkhaul adotou as medidas razoáveis para mitigar o prejuízo, como a venda

\footnotetext{
${ }^{87}$ INGLATERRA e GALES. Reichman \& Anor v Beveridge \& Anor, [2006] EWCA Civ 1659 (13 December 2006). Disponível em: http://www.bailii.org/ew/cases/EWCA/Civ/2006/1659.html. Acesso em 20/02/2014.

${ }^{88}$ INGLATERRA e GALES. Bulkhaul Ltd $v$ Rhodia Organique Fine Ltd [2008] EWCA Civ 1452 (18 December 2008). Disponível em: http://www.bailii.org/ew/cases/EWCA/Civ/2008/1452.html. Acesso em 20/02/2014.
} 
ou aluguel dos tanques para terceiros para reduzir suas perdas e danos caso exista mercado para tanto. Após a produção de provas no processo, a Corte entendeu que a Bulkhaul tinha sim que mitigar seus danos, vendendo os tanques para terceiros - inclusive indicados pela própria Rhodia -, o que não foi feito. Ficou consignado, inclusive, que caso a mitigação fosse realizada, poderia a Bulkhaul pedir indenização pela diferença do preço conseguido no mercado e o valor contratado. Pela inobservância do duty to mitigate the loss, a Bulkhaul não alcançou a indenização pretendida. 


\section{A NATUREZA JURÍDICA DO DUTY TO MITIGATE THE LOSS}

Tendo sido estudada a presença do duty to mitigate the loss no direito romano e na common law, é chegado o momento de analisá-lo no direito pátrio, sendo deveras oportuno o início pela sua natureza jurídica. Neste capítulo, portanto, será feita uma revisão das principais correntes apontadas como natureza jurídica da norma de mitigação além de, ao final, serem tecidas críticas - baseadas no que fora desenvolvido - ao termo duty, largamente utilizado por aqueles que introduziram o instituto da mitigação no Brasil.

\subsection{O princípio da boa-fé}

O conceito de boa-fé é de difícil definição. Esta nebulosidade foi bem identificada por Menezes Cordeiro ${ }^{89}$, compreendendo a sua histórica e larga utilização nas relações sociais, embora padecendo do desconhecimento de seus reais contornos. Tendo em vista as diversas situações as quais se amolda, comumente é tratado por quem o estuda de maneira vaga e imprecisa. Não é a toa que se costuma assimilar a boa-fé às noções de justiça, equidade, equilíbrio e lealdade, isto é, expressões de alta abstração, assim como a própria boa-fé é, ou a instituições metajurídicas, como a ética e a moral ${ }^{90}$.

No direito germânico, a boa-fé teve abordagem diferenciada a partir da entrada em vigor do Código Civil alemão (BGB), que trouxe consigo a separação entre os conceitos de boa-fé subjetiva (Guter Glauben) e objetiva (Treu und Glauben). A boa-fé subjetiva ficou ligada à ideia de um estado psicológico, um estado de ânimo ou espírito do agente, sem conhecimento do vício existente e que acredita se comportar em conformidade com o direito. É um estado anímico derivado do reconhecimento da ignorância acerca de determinada circunstância ${ }^{91}$.

A boa-fé objetiva, por sua vez, traz um dever de agir de maneira honesta, com probidade, lisura e lealdade, como forma de não frustrar a legítima confiança da outra

\footnotetext{
${ }^{89}$ CORDEIRO, Antonio Manuel da Rocha e Menezes. Da Boa Fé no Direito Civil. 4 a reimpressão. Coimbra: Almedina, 2001.p. 41.

${ }^{90}$ Idem, ibidem. p. 45.

${ }^{91}$ Como no caso do possuidor de boa-fé amplamente amparado pela legislação civil brasileira nos artigos $1.214,1.216,1.217,1.218,1.219,1.220$ e 1.242 .
} 
parte. Como leciona Martins-Costa ${ }^{92}$, trata-se de consideração para com as expectativas legitimamente geradas. É norma de fundo ético, em que se exige juridicamente um comportamento para com a outra parte, ou seja, é uma regra de conduta ${ }^{93}$.

O direito alemão traduziu na fórmula Treu und Glauben a boa-fé obrigacional, inserindo as ideias de lealdade (Treu) e confiança (Glauben) além do subjetivismo da bona fides dos romanos.

\begin{abstract}
A fórmula Treu und Glauben demarca o universo da boa-fé obrigacional proveniente da cultura germânica, traduzindo conotações totalmente diversas daquelas que a marcaram no direito romano: ao invés de denotar a ideia de fidelidade ao pactuado, como num das acepções da fides romana, a cultura germânica inseriu, na fórmula, as ideias de lealdade (Treu ou Treue) e crença (Glauben ou Glaube), as quais se reportam a qualidades ou estados humanos objetivados ${ }^{94}$.
\end{abstract}

No direito pátrio, a primeira vez que a boa-fé apareceu expressamente na legislação foi no Código Comercial de 1850 , em seu artigo 131, item $1^{95}$. Todavia, não lhe foi concedida a devida amplitude de significado, restringindo-o a uma mera função interpretativa, para que o sentido literal da linguagem do negócio não prevalecesse sobre a intenção manifestada na declaração e vontade, ou dela inferível.

Foi, igualmente, a interpretação dada ao posterior artigo 85 do Código Civil de $1916^{96}$. Conforme leciona Judith Martins-Costa, a pretensão de Clóvis Beviláqua à plenitude da legislação e sua excessiva preocupação com a segurança, certeza e clareza não permitiram a inserção de cláusulas gerais e, por tal razão, a boa-fé acabou por constar tão restrita $^{97}$.

\footnotetext{
92 MARTINS-COSTA, Judith. A Boa-fé no Direito Privado: sistema e tópica no processo obrigacional. São Paulo: Revista dos Tribunais, 2000. p. 412.

${ }_{93}$ CORDEIRO, Antonio Manuel da Rocha e Menezes. Da Boa Fé no Direito Civil. 4 a reimpressão. Coimbra: Almedina, 2001. p. 648-649.

${ }^{94}$ MARTINS-COSTA, Judith. A Boa-fé no Direito Privado: sistema e tópica no processo obrigacional. São Paulo: Revista dos Tribunais, 2000. p. 124.

${ }_{95}$ Art. 131 - Sendo necessário interpretar as cláusulas do contrato, a interpretação, além das regras sobreditas, será regulada sobre as seguintes bases:

1 - a inteligência simples e adequada, que for mais conforme à boa fé, e ao verdadeiro espírito e natureza do contrato, deverá sempre prevalecer à rigorosa e restrita significação das palavras;

${ }^{96}$ GOMES, Orlando. Contratos. $9^{\text {a }}$ ed. Rio de Janeiro: Forense, 1983. p. 43. O artigo 85 tinha a seguinte redação: "Nas declarações de vontade se atenderá mais à sua intenção que ao sentido literal da linguagem".

${ }^{97}$ MARTINS-COSTA, Judith. A Boa-fé no Direito Privado: sistema e tópica no processo obrigacional. São Paulo: Revista dos Tribunais, 2000. p. 267.
} 
Só com o advento do Código de Defesa do Consumidor, em 1990, que a boa-fé recebeu tratamento adequado na legislação brasileira. A boa-fé não mais serviu apenas para a interpretação de cláusulas contratuais, mas também para o preenchimento de lacunas, delimitação de direitos e criação de deveres jurídicos anexos. Adotou, implicitamente, a boa-fé como cláusula geral ${ }^{98}$. O artigo $4^{\circ}$, inciso III dispõe que a Política Nacional das Relações de Consumo deve atender à harmonização dos interesses dos participantes das relações de consumo e compatibilização da proteção do consumidor com a necessidade de desenvolvimento econômico e tecnológico, de modo a viabilizar os princípios nos quais se funda a ordem econômica, sempre com base na boa-fé e equilíbrio nas relações entre consumidores e fornecedores. O artigo 51, IV, por sua vez, considera nulas de pleno direito as cláusulas que sejam incompatíveis com a boa-fé.

Finalmente, no ano de 2002, o novo Código Civil trouxe previsão mais abrangente da boa-fé que o Código anterior, tratando-a verdadeiramente como cláusula geral e considerando-a tanto na acepção subjetiva quanto objetiva, com funções além daquelas previstas anteriormente e se equiparando ao tratamento dado nas relações de consumo. A boa-fé objetiva foi explicitamente referenciada nos artigos 113, 187 e 422 do Código Civil, como uma norma com alta carga de abstração que irriga todo o ordenamento jurídico, com a finalidade de adequar comportamentos conforme sua carga valorativa. Estruturou-se como norma ético-social, em que se baseia em um padrão de conduta honesto e leal e que se utiliza de

um modelo de pessoa imaginária, normal, razoável, com o fito de averiguar o sentido que essa pessoa abstrata atribuiria à declaração negocial, nas mesmas circunstâncias em que se encontravam declarante e declarário verdadeiros ${ }^{99}$.

Em razão desta comparação hipotética, com aspirações universalizantes de estabelecimento de padrões de comportamento, pode-se dizer que a boa-fé objetiva é tanto um princípio geral de Direito quanto de Direito Civil ${ }^{100}$ : irriga todo o ordenamento jurídico, incidindo em todas as relações jurídicas.

\footnotetext{
${ }^{98}$ GRINOVER, Ada Pellegrini et al. Código Brasileiro de Defesa do Consumidor comentado pelos autores do Anteprojeto. 9. ed. Rio de Janeiro: Forense Universitária, 2007. p. 580-581.

${ }_{99}$ MARINO, Francisco Paulo De Crescenzo. Interpretação do Negócio Jurídico. $1^{\text {a }}$ ed. São Paulo: Saraiva, 2011. p. 185.

${ }^{100}$ GARCIA, Enéas Costa. Responsabilidade pré e pós-contratual à luz da boa-fé. $1^{\mathrm{a}}$ ed. São Paulo: Juarez de Oliveira, 2003. p. 322.
} 
Assim, o artigo 113 do Código Civil, ao determinar que os negócios jurídicos sejam interpretados conforme os ditames da boa-fé, não faz alusão apenas à sua função interpretativa. Deve-se entender a aplicação da boa-fé como um todo, atuante em todas as suas funções na medida em que for possível diante do caso concreto. Por isso, não parece pertinente fragmentá-la para que seja aplicado simplesmente no aspecto que pareça ser interessante, sob pena de desvirtuar a sua finalidade.

A propósito, interpretação semelhante é realizada no artigo 422 do Código Civil. Sua redação parece mandar observar o princípio da boa-fé do período da conclusão do contrato até a sua execução, isto é, afastando sua aplicação nas fases pré e pós-contratuais. A doutrina, todavia, faz a leitura a partir de uma interpretação teleológica e evolutiva, alçando a boa-fé como norma de regência de todo o contato negocial ${ }^{101}$.

Trata-se da adoção pelo ordenamento jurídico brasileiro das chamadas cláusulas gerais $^{102}$. Pela leitura dos artigos mencionados alhures, nota-se que há somente uma referência à boa-fé, sem que, em momento algum, haja alguma definição de seu conteúdo. Trata-se de uma abertura necessária e geral que permite que o juiz, na análise do caso concreto, verifique numa relação obrigacional se as posturas dos sujeitos estão em conformidade com os ditames da boa-fé, tendo em mente a carga axiológica do referido princípio.

Cláusulas gerais não são simples instrumentos de abertura do sistema para os princípios, mas também acabam por determinar standards jurídicos, ou seja, um modelo de comportamento médio, um referencial de conduta esperada dos indivíduos. Em uma análise comparativa, é possível verificar se um indivíduo tomou os cuidados mínimos e adequados exigidos na medida do exemplo ideal. E o princípio da boa-fé, ao irrigar o sistema através das cláusulas gerais, também determina um

\footnotetext{
${ }^{101}$ Idem, ibidem. p. 311.

102 "Considerada do ponto de vista da técnica legislativa, a cláusula geral constitui, portanto, uma disposição normativa que utiliza, no seu enunciado, uma linguagem de tessitura intencionalmente 'aberta', 'fluida' ou 'vaga', caracterizando-se pela ampla extensão do seu campo semântico, a qual é dirigida ao juiz de modo a conferir-lhe um mandato (ou competência) para que, à vista dos casos concretos, crie, complemente ou desenvolva normas jurídicas, mediante o reenvio para elementos cuja concretização pode estar fora do sistema; estes elementos, contudo, fundamentarão a decisão, motivo pelo qual, reiterados no tempo os fundamentos da decisão, será viabilizada a ressistematização destes elementos originariamente extrasistêmicos no interior do ordenamento jurídico". (MARTINS-COSTA, Judith. A Boa-fé no Direito Privado: sistema e tópica no processo obrigacional. São Paulo: Revista dos Tribunais, 2000. p. 299)
} 
modelo de conduta social, arquétipo ou standard jurídico, segundo o qual cada pessoa deve ajustar a própria conduta a esse arquétipo, obrando como obraria um homem reto: com honestidade, lealdade, probidade ${ }^{103}$.

A boa-fé, portanto, pode ser verificada tanto como um princípio quanto como uma cláusula geral ou um standard. O que muda é o seu grau de abstração e nível de análise: o princípio da boa-fé determina em sua carga axiológica de grande abstração o comportamento leal, honesto e probo. Como meio de tradução destes valores, determina standards, modelos em consonância com o comportamento considerado ideal, o que se exige que um indivíduo razoavelmente realize. No entanto, para que estes valores e arquétipos ingressem no sistema, é preciso que o ordenamento jurídico tenha uma abertura como meio de concretização dos valores contidos no princípio e dos arquétipos que ele apresenta, servindo para tanto as cláusulas gerais. Assim, as cláusulas gerais, com enunciados propositadamente vagos, servem de instrumento de desenvolvimento da normatização das situações concretas apresentadas, de aplicação do princípio às relações jurídicas existentes.

Para este estudo, a boa-fé será objeto de investigação como uma possível estrutura para o duty to mitigate the loss, servindo de fundamento para a sua recepção no ordenamento jurídico brasileiro. Por meio da análise de suas peculiaridades, será determinado se a norma de mitigação, como um ônus, é adequada para se encaixar na estrutura da boa-fé.

\subsubsection{Funções da boa-fé}

A boa-fé objetiva é uma faceta do princípio jurídico da boa-fé que tem por finalidade assegurar a confiança entre os pactuantes. Para tanto, deve ter incidência em múltiplos aspectos da relação jurídica, influenciando de maneiras diferentes os diversos estágios em que se dá a formação de um negócio jurídico ${ }^{104}$.

\footnotetext{
${ }^{103}$ MARTINS-COSTA, Judith e BRANCO, Gerson Luiz Carlos. Diretrizes Teóricas do Novo Código Civil Brasileiro. São Paulo: Saraiva, 2002.

${ }^{104}$ Pode-se dizer que a boa-fé, na busca de um ideal de justiça, interfere, por exemplo, na fase pré-contratual, durante a execução do contrato e na fase pós-contratual. E embora algumas de suas funções sejam iguais, é possível notar outras diferentes, que serão apontadas mais adiante.
} 
Para este estudo, reunimos as funções da boa-fé objetiva em três grandes grupos ${ }^{105}$ : função interpretativa e de colmatação, função criadora de deveres jurídicos anexos ou de proteção e função delimitadora do exercício de direitos subjetivos. Vejamos cada uma delas separadamente.

\subsubsection{Função interpretativa e de colmatação}

Através da função interpretativa, extrai-se da norma - ainda que exclusiva entre as partes, como no caso de um contrato - o sentido que mais se aproxima do justo, espelhando confiança, lealdade, honestidade e assistência entre as partes. Busca-se, portanto, a interpretação que mais se aproxime da finalidade do negócio jurídico.

Orlando Gomes ${ }^{106}$ destaca esta função como a mais importante, ao entender que o princípio da boa-fé se relaciona mais com a interpretação do contrato que a estrutura. Afinal, o literal da linguagem não deve prevalecer sobre a manifestação da intenção ou aquela que seria possível inferir no caso.

A função interpretativa da boa-fé deve ser aplicada para, ao menos, retificar pequenos vícios na declaração de vontade, pois o esforço interpretativo tem por finalidade principal a manutenção da relação jurídica. Isto significa que inicialmente o intérprete deve tentar encontrar uma solução que atenda ao equilíbrio jurídico à luz do princípio da boa-fé, devendo evitar recorrer ao máximo à extinção da relação se esta não é a intenção das partes.

Neste sentido, a boa-fé especifica o conteúdo do negócio jurídico ${ }^{107}$. Conforme explicita Marino $^{108}$, sob a alcunha de fase interpretativa complementar, o princípio da boafé, além de sanar as ambiguidades, obscuridades e lacunas, serve de critério para revelar cláusulas que não estão expressas no negócio, mas estão presentes em seu conteúdo global.

Na legislação brasileira, é possível encontrar referência que pode servir de diretriz para a função interpretativa do princípio da boa-fé. O artigo 113 do Código Civil determina

\footnotetext{
${ }^{105}$ Baseado na classificação de GAGLIANO, Pablo Stolze; PAMPLONA FILHO, Rodolfo. Novo Curso de Direito Civil 4 Tomo I Contratos: teoria geral. $8^{\mathrm{a}}$ ed. rev. atual. e ampl. São Paulo: Saraiva, 2012. p. 107.

${ }^{106}$ GOMES, Orlando. Contratos. $9^{a}$ ed. Rio de Janeiro: Forense, 1983. p. 43.

${ }^{107}$ MARTINS-COSTA, Judith. A Boa-fé no Direito Privado: sistema e tópica no processo obrigacional. São Paulo: Revista dos Tribunais, 2000. p. 428-432.

${ }^{108}$ MARINO, Francisco Paulo De Crescenzo. Interpretação do Negócio Jurídico. $1^{\text {a }}$ ed. São Paulo: Saraiva, 2011. p. 274.
} 
que os negócios jurídicos devam ser interpretados conforme a boa-fé e os usos do lugar de sua celebração.

No tocante à função de colmatação, trata-se de uma decorrência da própria função interpretativa, tendo em vista que a boa-fé serve como orientação para o preenchimento de lacunas pelo magistrado. Desse modo, na ausência de normas expressas, a boa-fé guiará o julgador na busca pelo "espírito" ou intenção real das partes na celebração do negócio jurídico.

\subsubsection{Função criadora de deveres jurídicos anexos}

Além das funções já apresentadas, o princípio da boa-fé também cria deveres jurídicos para as partes, com a finalidade de proteger o pacto firmado entre elas. $\mathrm{Na}$ doutrina são encontradas diversas nomenclaturas para tais deveres. Orlando Gomes ${ }^{109}$ chama-os de condições subentendidas. Garcia ${ }^{110}$, baseado no direito alemão e atento à imprecisão da nomenclatura, se utiliza da expressão deveres acessórios de conduta (Nebenpflichten).

Como o próprio nome diz, são deveres além da obrigação principal ${ }^{111}$, existentes a partir da fase pré-contratual e que se estendem até a fase pós-contratual. Impõem deveres laterais de conduta às partes para que haja, como objetivo final, o cumprimento correto e integral do negócio jurídico, protegendo a própria pessoa e seus bens.

Sendo auxiliares, não se prestam a realizar a obrigação principal, mas proteger os demais interesses correlatos. Assim como alerta Garcia ${ }^{112}$, não se pode confundi-los com deveres secundários (ou acidentais), porque estes guardam conexão com os deveres principais. Afinal, estes podem assumir duas facetas: substituir a prestação principal quando não realizada (sendo chamado de dever secundário com prestação autônoma) ou ser acessório da prestação principal.

\footnotetext{
${ }^{109}$ GOMES, Orlando. Contratos. 9a ed. Rio de Janeiro: Forense, 1983. p. 43.

${ }^{110}$ GARCIA, Enéas Costa. Responsabilidade pré e pós-contratual à luz da boa-fé. $1^{\mathrm{a}}$ ed. São Paulo: Juarez de Oliveira, 2003. p. 98.

${ }_{111}^{11}$ A doutrina alemã os chama de Nebenpflichten, que pode ser traduzido como "além das obrigações".

112 GARCIA, Enéas Costa. Responsabilidade pré e pós-contratual à luz da boa-fé. $1^{\mathrm{a}}$ ed. São Paulo: Juarez de Oliveira, 2003. p. 99.
} 
O primeiro caso fica evidente quando há indenização por perdas e danos por conta do inadimplemento ou quando há complementação da obrigação principal, como é o caso da indenização pela mora. O segundo caso guarda uma relação de instrumentalidade com a obrigação principal, dirigidos exclusivamente para o adimplemento desta. É a hipótese, por exemplo, de existir o dever de embalar o produto vendido.

Dessa maneira, os deveres jurídicos anexos, oriundos do princípio da boa-fé, existem para satisfazer amplamente a relação obrigacional, em todos os aspectos incidentes, sem se limitar à realização da obrigação principal. Não se limitam, portanto, a preparar sua realização, mas a auxiliam através da tutela de interesses relacionados.

Assim como frisa Couto e Silva ${ }^{113}$, tais deveres abrangem toda a relação jurídica. Podem ser examinados durante o curso e desenvolvimento da relação jurídica, inclusive após o adimplemento da obrigação principal.

Importante frisar que não se tratam de deveres constantes em um rol taxativo, pois acabaria por limitar o alcance do princípio da boa-fé, o que seria extremamente contraditório por se tratar de um mandamento de otimização. Ademais, é da natureza do princípio da boa-fé existir esta abertura, sendo concretizado pela análise do caso concreto. Por isso, amparado pelas lições de Martins-Costa ${ }^{114}$ e Garcia ${ }^{115}$, pode-se enumerar os seguintes deveres jurídicos anexos:
a) dever de cuidado ou proteção;
b) deveres de lealdade e confiança recíproca;
c) deveres de confidencialidade e omissão;
d) dever de informação;
e) dever de cooperação.

\footnotetext{
${ }^{113}$ SILVA, Clóvis Couto e. A obrigação como processo. São Paulo: José Bushatsky, 1976. p. 113.

${ }^{114}$ MARTINS-COSTA, Judith. A Boa-fé no Direito Privado: sistema e tópica no processo obrigacional. São Paulo: Revista dos Tribunais, 2000. p. 439.

${ }^{115}$ GARCIA, Enéas Costa. Responsabilidade pré e pós-contratual à luz da boa-fé. $1^{\mathrm{a}}$ ed. São Paulo: Juarez de Oliveira, 2003. p. 105.
} 


\subsection{Dever de cuidado ou proteção}

Por este dever, as partes têm a obrigação de zelar tanto o próprio sujeito da relação obrigacional quanto o seu patrimônio. Aquele que integra como parte de um negócio jurídico deve se esforçar na medida do possível para que não prejudique o patrimônio moral e material da contraparte.

Como exemplifica Martins-Costa ${ }^{116}$, aquele que é depositário tem o dever de acondicionar bem o objeto do depósito, assim como o proprietário de uma sala de espetáculos tem o dever de planejá-la de tal forma que diminua os riscos de acidentes. Em ambos os casos, há um dever jurídico anexo de zelar pela segurança do bem e do próprio ser humano.

Não se confunde, contudo, com a responsabilidade civil. Nesta, a violação da esfera jurídica de outrem tem como consequência o surgimento da necessidade de reparação do dano. Já no dever de cuidado, como se trata de dever auxiliar, sua violação por si só não se traduz num mandamento indenizatório. Na verdade, explicita que sua violação pode ter prejudicado o cumprimento da obrigação principal, ensejando um reequilíbrio entre as partes segundo os ditames da boa-fé. Portanto, conforme alerta Garcia ${ }^{117}$, a responsabilidade pela violação do dever de proteção é contratual e não aquiliana. Caberá ao lesado a prova do inadimplemento da prestação, ao passo que a contraprova se limita ao caso fortuito, força maior ou ausência de culpa.

O dever de cuidado se aproxima bastante do dever de informar, que será visto adiante, quando se está diante de um necessário alerta a ser feito à outra parte. Chamado de mise en garde, implica num aviso de um perigo que pode expor a vida, saúde ou segurança da parte contrária em risco. Trata-se de medida de fundamental importância, pois normalmente busca tutelar direitos indisponíveis. Assim, informando do perigo de determinada atividade ou do conteúdo do objeto da obrigação, a parte estará, ao menos à luz da boa-fé, cumprindo seu dever de proteção.

\footnotetext{
${ }^{116}$ MARTINS-COSTA, Judith. A Boa-fé no Direito Privado: sistema e tópica no processo obrigacional. São Paulo: Revista dos Tribunais, 2000. p. 439.

${ }^{117}$ GARCIA, Enéas Costa. Responsabilidade pré e pós-contratual à luz da boa-fé. $1^{\mathrm{a}}$ ed. São Paulo: Juarez de Oliveira, 2003. p. 229.
} 


\subsection{Deveres de lealdade e confiança recíproca}

Embora comumente sejam tratadas como parte da própria conceituação do princípio da boa-fé, é importante destacar que a lealdade e confiança recíproca também ensejam deveres, haja vista que traduzem a fidelidade aos compromissos assumidos. Ainda que seja uma noção bastante ampla, infere com o conceito de lealdade o estabelecimento de relações com base na transparência e na verdade, isto é, em sintonia com o que é manifestado e o que é praticado.

O dever de lealdade traz em seu âmago a necessidade de um comportamento honesto, em consonância com a ética exigida na relação obrigacional. Trata-se de dever de conteúdo positivo, pois obriga um agir de forma diligente.

Garcia $^{118}$ assevera com razão que o dever de lealdade e confiança recíproca se torna bastante perceptível quando há sua violação ao invés de ser notável a priori. Isto se percebe claramente quando há violação do venire contra factum proprium, ou seja, quando a parte toma uma atitude contraditória àquela tomada anteriormente, sendo que havia criado uma expectativa legítima que isto não ocorreria ${ }^{119}$. Ainda assim, isto não tira a sua importância ou a obrigatoriedade de sua observância. A consideração para com a outra parte, embora de ampla semântica, já impõe uma conduta que se preocupe em preservar a confiança depositada em razão da relação obrigacional.

A existência de confiança em quem com que se celebra um negócio jurídico é crucial para o seu devido cumprimento. Sem um mínimo de confiança, não se pode afirmar que as partes empregam o melhor de seus esforços para cumprir suas obrigações. Ao contrário, se esforçarão muito mais para se precaver de qualquer ataque do coobrigado, desenvolvendo-se a relação jurídica sempre com o temor do inadimplemento e do dano.

\subsection{Deveres de confidencialidade e omissão}

Também conhecido como dever de sigilo, possui o condão de proteger as partes da revelação indevida de informações sigilosas que porventura tiveram contato dentro de todo

\footnotetext{
${ }^{118}$ Idem, ibidem. p. 198.

${ }^{119} \mathrm{O}$ tema será mais bem desenvolvido no item 2.2.1. infra.
} 
o período contratual, incluindo o pré e o pós-contratual. Desse modo, ainda que o negócio não seja concluído, as informações confidenciais estão protegidas por este dever anexo da boa-fé.

Não apenas acerca dos negócios é que há o dever de sigilo, como no caso de divulgação entre os pactuantes de documentos técnicos, planilhas, etc. O dever de sigilo pode recair sobre a pessoa do negociante, quando informações pessoais devem ser mantidas em segredo como, por exemplo, o sigilo bancário ou questões relativas à intimidade.

Então, se uma parte tem acesso a informações sigilosas antes da formação do contrato - na fase de negociações preliminares -, ela está impedida de divulgá-las, ainda que o negócio não tenha sido celebrado. Da mesma forma, caso o negócio já tenha sido cumprido, não cabe à parte, à luz da boa-fé, revelar dados confidenciais.

Com efeito, o dever de confidencialidade, no modelo de responsabilidade contratual, não abrange aquelas informações confidenciais pelas quais se tomou conhecimento por outra origem. Isto não quer dizer, contudo, que torna lícita a divulgação, mas torna a responsabilidade extracontratual.

O dever de confidencialidade, por óbvio, não deixa de ser um desdobramento do dever de lealdade. Afinal, a abstenção da divulgação de dados sigilosos não deixa de ser um comportamento honesto e ético da parte. No entanto, dada a sua especificidade e importância, costuma receber tratamento próprio da doutrina ${ }^{120}$.

\subsection{Dever de informação}

Como maneira de manter ou recuperar a igualdade entre as partes contratantes, corrigindo a informação assimétrica ${ }^{121}$, o princípio da boa-fé também cria o dever jurídico anexo de informação. Trata-se de dever de suma importância, pois é capaz de conciliar a

\footnotetext{
${ }^{120}$ MARTINS-COSTA, Judith. A Boa-fé no Direito Privado: sistema e tópica no processo obrigacional. São Paulo: Revista dos Tribunais, 2000. p. 439; GAGLIANO, Pablo Stolze; PAMPLONA FILHO, Rodolfo. Novo Curso de Direito Civil 4 Tomo I Contratos: teoria geral. $8^{\mathrm{a}}$ ed. rev. atual. e ampl. São Paulo: Saraiva, 2012. p. 114; GARCIA, Enéas Costa. Responsabilidade pré e pós-contratual à luz da boa-fé. $1^{\mathrm{a}}$ ed. São Paulo: Juarez de Oliveira, 2003. p. 219-221; PEREIRA, Caio Mário da Silva. Instituições de Direito Civil Vol. III. $12^{\text {a }}$ ed. Rio de Janeiro: Forense, 2006. p. 21.

${ }^{121}$ TOMASEVICIUS FILHO, Eduardo. Informação assimétrica, custos de transação, princípio da boa-fé. São Paulo, 2007. Tese (Doutorado em Direito). Faculdade de Direito da Universidade de São Paulo. p. 283284.
} 
autonomia da vontade, princípio fundamental para a formação dos negócios jurídicos, com a responsabilidade advinda da boa-fé. Elimina, pois, uma visão extremamente individualista ao impor às partes uma preocupação de informar a outra de todas as características e circunstâncias do negócio.

Tomasevicius Filho ${ }^{122}$, trazendo interessante retrospecto histórico, nota que o dever de informar já se mostrava latente desde a Antiguidade, pois o direito já impunha ao vendedor o dever de se preocupar com os interesses do comprador. E isto acabou refletido na Idade Média com a doutrina da Igreja de correição em todos os atos dos indivíduos, propondo a abstenção de enganar os semelhantes.

Além disso, com o desenvolvimento da burguesia e o consequente declínio do sistema feudal, houve profunda alteração no comércio, tornando-o uma essencialidade para a satisfação das necessidades humanas. Aliado a isto, cada vez mais a atividade comercial se tornou desregulamentada, dando margem à prática de abusos e fraudes. Então, concebeu-se a expressão caveat emptor ("o comprador que se cuide") para explicitar o ônus do comprador de examinar com rigor o bem a ser adquirido.

Claro que a lógica de mercado, à época, era outra. Não existiam os avanços tecnológicos do século XX e XXI, tornando a produção do mercado especializada e técnica, fazendo com que pessoas juridicamente "capazes" se tornassem vulneráveis ${ }^{123}$. A concepção, portanto, teve que ser ampliada: no império do caveat emptor, com as dificuldades de obter informações pelo comprador, fez com que surgisse o caveat venditor ${ }^{124}$ ("o vendedor que se cuide").

A obrigação de informar, portanto, é de suma importância para a relação negocial. Pelo outro lado da moeda, é uma vedação de enganar, haja vista que quanto mais as partes são informadas, maiores as chances de que realizem um negócio sem incorrer em erro. Neste sentido, é possível até estabelecer uma relação com o dever de lealdade e confiança

\footnotetext{
${ }^{122}$ Idem, ibidem. p. 279-284.

${ }^{123}$ Idem, ibidem. p. 282.

${ }^{124}$ Entende-se que esta expressão tem origem no caso MacPherson v. Buick Motor Co., julgado em 1916 pela Corte de Apelação de Nova Iorque. Em síntese, MacPherson sofreu uma lesão quando uma das rodas de madeira de seu veículo se desprendeu. A Buick Motor Co. se defendeu alegando que a roda foi produzida por outro fornecedor e, além disso, MacPherson não havia adquirido o veículo diretamente da Buick Motor Co. A ação foi julgada procedente, pelo argumento de que a Buick Motor Co. celebrou voluntariamente contrato com a fornecedora de rodas e os produtos vendidos por aquela devem transmitir uma confiança de que são seguros e confiáveis para o uso. (CLARK, John Kirkland. Let the Maker Beware. St. John's Law Journal. vol. $19, \mathrm{n}^{\mathrm{o}} 2,2^{\mathrm{a}}$ ed., p. 85-94, abril de 1945. p. 85-86)
} 
recíproca, pois impede a ocorrência de omissões dolosas, tornando claros os direitos e deveres de cada uma das partes.

Logicamente, a obtenção da informação não precisa necessariamente ser realizada a partir de uma ação da parte contrária. O próprio beneficiário, mediante cognição vulgar, ou seja, não dotado de certeza por não ter sido verificado, mas com possibilidades de ser autêntico $^{125}$. Em outras palavras, com o simples contato com o objeto, de maneira espontânea, a parte poderá angariar informações sobre ela, ainda que bem simples.

O dever de informar, todavia, não se contenta com a simples exposição da coisa. Sendo um dever, obriga as partes a entrarem em contato, dialogarem sobre as características do produto, sobre as condições e circunstâncias do negócio e, se necessário por conta da natureza do negócio e à luz da boa-fé, realizar experimentos. O esclarecimento evidencia a realidade, evitando o erro e a ignorância.

Não se contenta, também, somente com o período pré-contratual. O dever de informar, como consideração pela outra parte que é, irriga todas as fases, mesmo após o encerramento da relação contratual. É que a informação se mostra muito mais necessária e urgente no período pré-contratual, em que as partes estão criando os laços de confiança e estabelecendo as estruturas do negócio a ser celebrado. Sendo assim, a informação incrementa notavelmente o nível de lealdade ${ }^{126}$.

É consenso que o dever de informar não é ilimitado. Suas fronteiras são o objeto e o conteúdo do negócio, não sendo necessário que as partes informem a sua oportunidade ${ }^{127}$. Entretanto, só esta conceituação, à primeira vista, se mostra insuficiente, já que parece ser preciso determinar qual o conteúdo do negócio que se mostra imprescindível de informação.

Por óbvio, é trabalho árduo e infrutífero determinar de antemão quais são os elementos do conteúdo do negócio que devem ser informados. Se já não é possível antever todas as hipóteses como se deve aplicar o princípio da boa-fé, mais nebulosa ainda é a possibilidade de previsão do conteúdo do que deve ser informado em cada caso. Neste diapasão, mais interessante é tratá-los como um conceito aberto, que invariavelmente fará

\footnotetext{
${ }^{125}$ REALE, Miguel. Filosofia do Direito. $20^{\mathrm{a}}$ ed. São Paulo: Saraiva, 2002. p. 54.

${ }^{126}$ GARCIA, Enéas Costa. Responsabilidade pré e pós-contratual à luz da boa-fé. $1^{\mathrm{a}}$ ed. São Paulo: Juarez de Oliveira, 2003. p. 112.

${ }^{127}$ Idem, ibidem. p. 113.
} 
entrar em conflito o princípio da boa-fé com o da autonomia da vontade, da privacidade e intimidade, etc.

Importante frisar que, quando se fala do objeto e conteúdo, também quer se referir ao comportamento das partes, que serão guiadas a partir das informações compartilhadas. Exige-se que se prestem informações sobre, por exemplo, o uso do produto, para que as partes se comportem devidamente e haja a plena e total execução do negócio.

Conforme visto anteriormente, também há a limitação quanto às informações sigilosas, caso não seja de interesse das partes revelá-las. Neste ponto, há uma limitação criada pelo próprio princípio da boa-fé, que deverá combinar - eliminando o aparente conflito - o dever de informação com o dever de sigilo. Trata-se de obrigação das partes de impedir que terceiros tenham ciência daquilo que é sigiloso, mas sem deixar de informar tudo aquilo que não está acobertado pela confidencialidade para a plena execução do negócio.

Também é tratada como limite a desnecessidade de informar o que a outra parte já sabe ou deveria saber ${ }^{128}$. O desconhecimento da informação, neste caso, é imputado à própria parte e, dessa maneira, é inescusável a alegação de que não sabia o que poderia ter se cientificado facilmente. Nesta hipótese, cabe a aplicação do caveat emptor e do caveat venditor.

O dever de informação também se desdobra no dever de aconselhamento. Neste caso, há um juízo de valor de uma parte que indica como a outra deve agir. Em sua natureza, é uma opinião fundada na experiência sobre determinado assunto para que haja a melhor tomada de decisão. Martins-Costa ${ }^{129}$ exemplifica com o caso do advogado de aconselhar seu cliente acerca da melhor via judicial ou do médico que esclarece sobre o melhor custo/benefício do tratamento escolhido.

Conforme será exemplificado através da jurisprudência no Título II, Capítulo 6, o dever de informação tem papel crucial em determinados casos para se identificar a incidência do ônus da mitigação. Isto porque há hipóteses em que a mitigação do prejuízo se dá através da comunicação do próprio credor de fato gravoso que o devedor não sabe ou não poderia saber por si próprio. Assim, a própria medida razoável para evitar ou

128 TOMASEVICIUS FILHO, Eduardo. Informação assimétrica, custos de transação, princípio da boa-fé. São Paulo, 2007. Tese (Doutorado em Direito). Faculdade de Direito da Universidade de São Paulo. p. 317.

${ }^{129}$ MARTINS-COSTA, Judith. A Boa-fé no Direito Privado: sistema e tópica no processo obrigacional. São Paulo: Revista dos Tribunais, 2000. p. 439. 
minimizar o prejuízo é o cumprimento pelo credor do dever jurídico anexo de informar, trazendo ao conhecimento do devedor que fatos decorrentes de seu inadimplemento estão lhe causando prejuízo.

\subsection{Dever de cooperação}

A noção de cooperação traz consigo a ideia de colaboração, assistência. Trata-se da união de esforços para a realização de um objetivo comum que, caso não fosse realizada dessa forma, seria muito mais desgastante, difícil ou, até mesmo, impossível para os envolvidos. Ora, se o objetivo do princípio da boa-fé é auxiliar e direcionar as tratativas entre as partes, não há expoente maior do que a cooperação para concretizá-lo.

Assim, o cumprimento do dever de cooperação se torna imprescindível para o desdobramento do negócio. Facilita, num primeiro plano subjetivo, as discussões, pois tudo o que se determina é transparente, realizado de forma consciente pelos participantes. Naquilo em que existe contraditório, há uma qualificação do discurso de cada um e um resultado mais próximo daquilo que é justo, pois cada argumento é analisado de maneira conciliatória, em busca do mais vantajoso a todos. Neste sentido, há maior assentimento entre os participantes que, no exercício de sua liberdade comunicativa ${ }^{130}$, trazem ao conhecimento de todos a realidade das suas próprias circunstâncias na negociação, execução e conclusão do negócio jurídico. Apresentam, de forma sincera e coerente, as suas razões.

Em um segundo plano objetivo, faz com que as obrigações sejam cumpridas da melhor maneira possível, com eficiência, probidade e atenção. Consequentemente, desgastes entre os envolvidos são evitados ou minimizados haja vista que haverá o exato cumprimento (ou, próximo disto) das prestações. Isto não significa que a parte deverá se esforçar além das suas forças ou até realizar obrigações que seriam da outra, mas não criar empecilhos desnecessários ao bom curso da relação obrigacional.

Portanto, enquanto que no plano subjetivo se traduz na consideração pela própria parte, no plano objetivo a consideração se dá pelo que é devido à outra parte. Realizar o dever de cooperação é, portanto, praticar a solidariedade contratual.

\footnotetext{
${ }^{130}$ HABERMAS, Jürgen. Direito e Democracia; entre facticidade e validade - Volume I. Rio de Janeiro: Tempo Brasileiro, 2003. p. 142.
} 
Faz-se necessário lembrar o alerta de Couto e Silva ${ }^{131}$ que o dever de cooperação não se confunde com um escambo, ou seja, em que o seu implemento só pode ser obtido se cada um cumprir suas obrigações. $\mathrm{Na}$ verdade, permeia toda a relação jurídica obrigacional, impondo conduta aos pactuantes. Por isso não se confunde com a obrigação principal, na qual se poderia alegar a exceptio non adimpleti contractus.

Do mesmo modo que ocorre com os demais deveres jurídicos anexos, o dever de cooperação permeia toda a relação jurídica obrigacional, desde a formação desta até após a sua execução. Não se coopera pontualmente, e sim, permanentemente.

O que se pode diferenciar dos demais deveres jurídicos anexos, no entanto, é a sua abrangência. Todos os demais deveres, ainda que explicitados e tratados separadamente no capítulo anterior, acabam por se enraizar no dever de cooperação ${ }^{132}$. Informar é cooperar com o outro prestando-lhe informações. Agir com lealdade também é colaborar, já que ser fiel aos compromissos assumidos é uma atitude cooperativa. Ter cuidado com o outro e seu patrimônio, da mesma maneira, é cooperar, pois impede a ocorrência de danos desnecessários. Guardar confidencialidade também, já que há a colaboração contra a revelação de dados sigilosos.

Mesmo assim, não se pode compreender tal configuração num encaixe perfeito, pois o dever de cooperação é mais abrangente que os demais deveres. Cooperar transcende os deveres de informação, lealdade, etc. Por isso, merece alocação especial, apartada, para que sejam evidenciados os seus importantes desdobramentos na relação obrigacional além daqueles já estudados, utilizando-nos de classificação criada por Tomasevicius Filho ${ }^{133}$.

\subsection{Condutas esperadas no exercício do dever de cooperação}

Ainda que não se trate de um rol exaustivo, é importante frisar algumas condutas das partes que são imprescindíveis quando se está diante de uma relação obrigacional. Com a abertura que o princípio da boa-fé permite - afinal, trata-se de mandamento que deve ser

\footnotetext{
${ }^{131}$ SILVA, Clóvis Couto e. A obrigação como processo. São Paulo: José Bushatsky, 1976. p. 117-118.

132 GARCIA, Enéas Costa. Responsabilidade pré e pós-contratual à luz da boa-fé. $1^{\mathrm{a}}$ ed. São Paulo: Juarez de Oliveira, 2003. p. 240.

133 TOMASEVICIUS FILHO, Eduardo. Informação assimétrica, custos de transação, princípio da boa-fé. São Paulo, 2007. Tese (Doutorado em Direito). Faculdade de Direito da Universidade de São Paulo. p. 398.
} 
realizado na maior medida possível, com conteúdo dinâmico -, outras condutas, a depender do caso concreto, podem ser de necessária observância.

Além disso, convém rememorar que os deveres jurídicos anexos não são isolados, atuando conjuntamente como forma de efetivação do princípio da boa-fé. Conforme fora explicado anteriormente, o dever de cooperação, em última análise, origina os demais deveres jurídicos anexos. Neste diapasão, as diferentes maneiras de se praticar a cooperação acabam se revelando também como o respeito e cumprimento dos deveres de informação, confidencialidade, lealdade, etc.

\subsection{1. Facilitar o adimplemento}

Assim como ao devedor interessa o cumprimento de sua obrigação para não sofrer as consequências de seu inadimplemento, também interessa ao credor receber a prestação devida. E para isto, faz todo o sentido que nenhuma das partes imponha obstáculos sem motivo justo.

A cooperação deve ser mútua: o credor deve realizar o que tiver ao seu alcance para que o devedor não encontre barreiras para cumprir sua obrigação. Da mesma forma, é preciso que o devedor atue de maneira a facilitar a realização da obrigação para que o credor venha a ter da maneira mais prática e fácil possível o seu crédito satisfeito. Existe, portanto, direitos de mão dupla: assim como o credor tem direito de receber, o devedor também tem o direito de adimplir.

Neste sentido, respeitar o princípio da boa-fé, sobretudo o dever de cooperação, é impedir com que a parte contrária tenha transtornos desnecessários que podem resultar em despesas extraordinárias: seja no momento da formação dos contratos quanto após a sua execução. O Código Civil traz exemplos claros, como no artigo 308 que obriga o pagamento ao credor ou a quem o represente devidamente; no artigo 327 que traz como regra geral de lugar de pagamento o domicílio do devedor; no artigo 331 a possibilidade de se exigir imediatamente o adimplemento caso não haja outro tempo convencionado, etc. Alterações nestas circunstâncias sem aviso prévio da outra parte originam transtornos desnecessários, vedados tanto expressamente pela legislação civil quanto pelo próprio princípio da boa-fé. 
Quando da formação do negócio, a facilitação do adimplemento já pode ocorrer desde as tratativas inaugurais, com as partes pré-estabelecendo cláusulas próprias para as situações que porventura poderão surgir. Como se vê, a tomada de tal atitude não se afasta do dever de informação, tendo em vista que as especificidades do negócio decididas de maneira cooperativa estarão iluminadas pela boa-fé.

Como os deveres jurídicos anexos não se extinguem mesmo após a execução do negócio, o dever de cooperação impõe que determinadas obrigações (as secundárias ${ }^{134}$, por exemplo) sejam cumpridas ainda que a obrigação principal tenha sido satisfeita. É o caso do artigo 32 do Código de Defesa do Consumidor que assegura a oferta de componentes e peças de reposição enquanto não cessar a fabricação ou importação do produto.

Dentro desta conduta também se pode destacar o que se convencionou chamar de adimplemento substancial (substantial performance). Com origem no Direito inglês pelas Cortes de Equity, surgiu para frear os exageros do formalismo exacerbado na execução dos contratos $^{135}$.

No Direito brasileiro, em regra, quando uma das partes não cumpre integralmente sua obrigação, abre a possibilidade conforme o artigo 475 e 476 do Código Civil de a outra pedir a resolução do contrato e exigir indenização pelas perdas e danos ou não cumprir sua obrigação em razão do inadimplemento daquela. Entretanto, existem situações em que o inadimplemento é tão mínimo perto do que já foi cumprido que a resolução ou até a alegação da exceptio non adimpleti contractus se torna medida desproporcional e irrazoável.

Surge então a teoria do adimplemento substancial fundada no princípio da boa-fé, que impede o credor de rescindir o contrato caso haja cumprimento de parte essencial da obrigação assumida pelo devedor, sem que perca o direito de obter o restante do crédito, podendo ajuizar ação de cobrança para tanto. Como leciona Clóvis Couto e Silva ${ }^{136}$, o substantial performance protege aquele adimplemento tão próximo ao resultado final que só torna possível o pedido de indenização e/ou adimplemento, excluindo o de resolução.

\footnotetext{
${ }^{134}$ Vide item 2.1.1.2. supra.

135 BECKER, Anelise. A doutrina do adimplemento substancial no Direito brasileiro e em perspectiva comparativista. In: Revista da Faculdade de Direito da Universidade Federal do Rio Grande do Sul, volume 9, nº 1, nov. 1993. p. 60-77.

${ }^{136}$ SILVA, Clóvis Couto e. O Princípio da Boa-Fé no Direito Brasileiro e Português. In: Estudos de Direito Civil Brasileiro e Português. São Paulo: Editora Revista dos Tribunais, 1980. p. 56.
} 
Ora, trata-se de nítida obrigação de facilitação fundada no dever de cooperação: o credor realizará sua contraprestação, pois o devedor adimpliu quase que em sua totalidade sua prestação. O inadimplemento não é fundamental, já que em grande parte houve a satisfação do interesse do credor. Por isso, à luz do princípio da boa-fé, o credor deverá facilitar o adimplemento, realizando o que lhe cabe no negócio.

\subsection{2. Manter a prestação interessante}

Quando se está prestes a realizar um negócio jurídico, é preciso que a oferta das partes desperte o interesse da outra. Se um fornecedor oferece um produto, este tem o dever de demonstrar para o consumidor que convém sua aquisição, assim como o consumidor deve transmitir segurança para o fornecedor que pagará o preço do produto. Há a necessidade de tornar a celebração do negócio atrativa.

Esta conduta fundada no dever de cooperação não termina com a celebração do negócio, mas se estende por toda a sua execução e depois de seu encerramento. Enquanto perdura o negócio, as partes devem continuar demonstrando a atratividade da sua continuidade, evitando que com o desinteresse aumente o risco de inadimplemento. Afinal, a ausência de satisfação fomenta o comportamento relapso, desatencioso e contrário à necessária cooperação.

Mesmo após a sua conclusão, ainda devem as partes manter o interesse, pois não é incomum que determinado negócio jurídico seja tomado como referência para outros

futuros. É o que ocorre comumente no comércio, no qual se recomenda um fornecedor para outro consumidor pela satisfação do serviço bem prestado.

Estes não são os únicos desdobramentos da necessária conduta de tornar a prestação interessante. Ela deve ser analisada também pelo prisma do adimplemento inadequado.

Em certos casos é possível verificar o cumprimento da obrigação, mas o modo que foi realizado é imperfeito, pois não se atendeu plenamente os interesses da outra parte. Tomasevicius Filho ${ }^{137}$ traz exemplo de um vendedor que despeja os tijolos que transportou em local inseguro ou empilha-os sem o devido cuidado, causando-lhes fissuras. Sem

\footnotetext{
137 TOMASEVICIUS FILHO, Eduardo. Informação assimétrica, custos de transação, princípio da boa-fé. São Paulo, 2007. Tese (Doutorado em Direito). Faculdade de Direito da Universidade de São Paulo. p. 405.
} 
sombra de dúvidas, houve o adimplemento da obrigação, mas o modo como foi realizada foi deficiente.

Antes mesmo da formação do negócio, com a oferta, há a obrigação de tornar a prestação interessante. $\mathrm{O}$ artigo 30 do Código de Defesa do Consumidor obriga o proponente a integrar a publicidade ou informação no contrato que vier a ser celebrado. Ora, mesmo na fase pré-contratual, o fornecedor poderá sofrer a sanção do desinteresse que fomentou com o oferecimento de cláusulas diferentes daquelas apresentadas na oferta: ser obrigado a praticar aquilo que está contido nesta.

Todos estes casos se relacionam ao que se convencionou chamar na doutrina de interesse positivo do contrato: exigir que se cumpra aquilo que foi determinado validamente no contrato. É a prestação compulsória daquilo que deveria ter sido realizado, mas não foi.

Em contraposição existe o conceito de interesse negativo ${ }^{138}$, correspondente ao prejuízo sofrido pela não formação ou conclusão do negócio jurídico. São os casos em que se exigem perdas e danos, lucro cessante e, a depender da situação, danos morais.

\begin{abstract}
Não tendo o contrato se formado, ou tendo sido concluído de maneira defeituosa (nulidade), não poderia a parte obter aquilo que lhe seria devido se o contrato produzisse validamente seus efeitos (interesse positivo). Por conseguinte, ao lesado apenas seria conferida a indenização do interesse negativo ${ }^{139}$.
\end{abstract}

É dever das partes, portanto, manter o interesse na prestação, tanto em razão da sua atratividade quanto para impedir violações ao interesse positivo.

\title{
2.1.1.2.5.1.3 Realizar da melhor maneira e de forma simples
}

Inexiste um modelo ideal de adimplemento das obrigações. A conduta perfeita depende da situação concreta, considerando todos os nuances próprios da natureza do negócio jurídico celebrado e/ou do que fora estipulado pelas partes. Ainda assim, é

\footnotetext{
${ }^{138}$ Embora a classificação em interesse negativo e positivo seja oriunda dos estudos de Ihering, o Direito alemão tende a se afastar destes conceitos, empregando a expressão Vertrauensschaden, que significa "danos à confiança", muito mais ampla e ligada ao conceito de boa-fé.

${ }^{139}$ GARCIA, Enéas Costa. Responsabilidade pré e pós-contratual à luz da boa-fé. $1^{\mathrm{a}}$ ed. São Paulo: Juarez de Oliveira, 2003. p. 284.
} 
imposto às partes, como modo de efetivação do dever de colaboração, que busquem o jeito mais simples, fácil e efetivo para o cumprimento da obrigação.

Mesmo que o devedor tenha a liberdade de escolher como deseja adimplir sua obrigação, não se trata de um direito absoluto, sofrendo restrições por outros direitos igualmente fundamentais e, principalmente, pelo princípio da boa-fé. Por isso, dentro de uma gama de possibilidades de se cumprir a obrigação, o devedor deverá selecionar aquela que atenderá melhor aos interesses tanto seus quanto do credor, da melhor maneira e com a maior simplicidade possível.

Novamente, é imperioso relembrar que não é necessário um desforço além das possibilidades das partes. Escolher a melhor maneira e a mais simples está dentro daquilo que é razoável se exigir. Com efeito, haverá uma violação em sentido oposto da boa-fé se a parte tiver que realizar despesas extraordinárias para cumprir a obrigação de modo além do que seria considerado possível, apenas porque a outra entende que seria este o melhor meio e o mais simples.

\subsection{Crise no dever de cooperação}

A relação obrigacional nem sempre se desenvolve como o esperado. Aliado aos demais institutos jurídicos, cabe ao princípio da boa-fé a correção da conduta das partes para que o negócio retorne ao seu rumo normal, de relação de solidariedade entre o credor e o devedor. Levando em conta que o dever de cooperação é a raiz do princípio da boa-fé, os desvios de conduta das partes acabam por distorcê-lo, fazendo com que não haja verdadeiramente uma cooperação, mas um esforço com intenções ocultas ou viciadas, que invariavelmente ampliam o atrito e o desgaste do vínculo.

Emilio Betti já trazia a lume casos que considerava patológicos de cooperação. Em sua obra Teoria Generale delle Obbligazioni discute não ser um problema isolado das obrigações, mas um fenômeno que se alastra por todas as relações sociais ${ }^{140}$. O excesso de especialização e fragmentação do conhecimento, da valorização da técnica, sem a

\footnotetext{
${ }^{140}$ BETTI, Emilio. Teoria Generale delle Obbligazioni, v. 1, Prolegomeni, Funzione Economico-Sociale dei Rapporti d'Obbligazione. Milano: Giuffrè, 1953. p. 28.
} 
preocupação com o ser humano que deveria ser o foco ao invés do instrumental parece ser, para Betti, o grande motivo do que chama de crise atual de cooperação ${ }^{141}$.

O primeiro caso patológico que identifica é o que denomina cooperação extorquida ou fraudada. São os casos em que há uma distorção da cooperação, em razão de violência ou fraude. Não há a livre manifestação de vontade, haja vista que a coação ou o dolo viciam o consentimento.

O segundo se trata da cooperação forçada ou chantageada, na qual há a imposição de uma obrigação desproporcional, em razão da necessidade da outra parte. É o mesmo caso da legislação civil pátria, quando se está diante do estado de necessidade ou da lesão: a prestação exigida é anormal, em um nítido desequilíbrio se comparada com a contraprestação, já que uma das partes se encontra numa situação de perigo ou de ignorância. Se não se encontrasse nesta situação, obviamente não aceitaria a celebração daquele negócio jurídico. Deve, pois, aderir à vontade do credor para não sofrer as consequências daquela situação danosa em particular.

Também é apresentada a cooperação sub-rogada, na qual a obrigação exigida de uma das partes é realizada por terceiro ou se exige satisfação equivalente por ser infungível. Neste caso, a patologia cooperativa consiste na má vontade ou inobservância dos deveres próprios da relação obrigacional, posicionamento diametralmente oposto ao que o princípio da boa-fé exige.

Por fim, trata da cooperação recusada. Embora a prestação seja devida, a parte insiste em se manter inadimplente. Como esclarece Betti ${ }^{142}$, esta patologia pode ser entendida também a favor do Direito, haja vista que da mesma forma que há a inadimplência ilícita pelo descumprimento dos termos contratuais, existe aquela que é permitida pelo ordenamento jurídico por conta do comportamento ilícito da outra parte. Assim, a parte poderá deixar de cumprir suas obrigações - ou até mesmo resolver o negócio jurídico - porque a outra já adotou postura contrária aos interesses e deveres anteriormente estabelecidos. Em outras palavras, quando a parte contrária deixou de cumprir seu dever de cooperação.

\footnotetext{
${ }^{141}$ Idem, ibidem. p. 29. Importante lembrar que a crítica também não deixa de ser o que a Escola de Frankfurt, representada por nomes como Jürgen Habermas, Axel Honneth, Max Horkheimer, Theodor W. Adorno, dentre outros, apresenta como característica da Modernidade. Marcada pelo uso exclusivo da razão instrumental, num cálculo frio e teórico, esqueceu-se das necessidades humanas. Assim, seria necessária a emancipação social e a implementação do viés humano em novos níveis contra as injustiças sociais e opressões homogeneizantes.

${ }^{142}$ Idem, ibidem. p. 34.
} 
Identificam-se assim duas acepções da cooperação recusada. A primeira acepção converge com o Direito, pois se admite a recusa de cooperação por existência de ato anterior que é contrário ao ordenamento jurídico. Afinal, não se pode exigir uma cooperação em qualquer situação, inclusive naquelas em que a parte é prejudicada. Como leciona Tomasevicius Filho ${ }^{143}$, agir de boa-fé não significa ser caridoso nem bondoso. É o caso da exceptio non adimpleti contractus prevista no artigo 476 do Código Civil

A segunda é contrária ao ordenamento jurídico, a qual se reverte, como regra geral na legislação civil brasileira, em perdas e danos, juros, atualização monetária e honorários de advogado, conforme preleciona o artigo 389. Só que esta não é a única consequência. A depender do caso, pode se reverter em uma tutela específica (artigo 461 e 461-A do Código de Processo Civil) ou numa redução equitativa da responsabilidade pelo inadimplemento com base principalmente no princípio da boa-fé. Em todas as hipóteses, logicamente, há incidência do princípio da boa-fé, mas no último ele apresenta especial importância, já que é o principal fundamento para restabelecer o equilíbrio entre as partes.

Destaca-se para este estudo a última patologia. Quando se está diante da necessidade de mitigação de um prejuízo, existe de maneira intrínseca a obrigação de se realizar o dever de cooperação, ainda que a norma de mitigação não se trate de um dever jurídico, e sim, de um ônus ${ }^{144}$. Isto porque ainda que não exista a responsabilidade do devedor de reparar totalmente o dano do credor - haja vista que parte dele se originou do desrespeito à norma de mitigação -, existem consequências futuras violadoras do dever de cooperação, como a cobrança indevida dos prejuízos pelo credor. Neste caso, o devedor terá despesas com a sua defesa além de um desgaste na relação obrigacional existente.

Sendo assim, além das consequências diretas que advém do ônus de mitigação do dano pelo credor, existem também os desdobramentos posteriores que acabam por revelar uma violação ao dever de cooperação. Em uma relação obrigacional de prestação continuada, na ocorrência de falta de mitigação dos prejuízos em uma das parcelas, a facilidade no adimplemento das demais fica prejudicada pela quebra de confiança. Igualmente, o descumprimento do ônus de mitigação das perdas não se mostra compatível com a realização da obrigação da melhor maneira ou da forma mais simples.

143 TOMASEVICIUS FILHO, Eduardo. Informação assimétrica, custos de transação, princípio da boa-fé. São Paulo, 2007. Tese (Doutorado em Direito). Faculdade de Direito da Universidade de São Paulo. p. 396.

${ }^{144}$ Conforme será visto no Título II, Capítulo 4, item 4.2. 
Referidas consequências são resultados do desrespeito ao dever de cooperação. Por isso, a sua violação é equivalente a um inadimplemento contrário ao ordenamento jurídico. Trata-se de um dever sobre o qual a parte não pode se negar a cumprir, já que imposto pelo princípio da boa-fé e, desse modo, sujeito às devidas consequências jurídicas. Portanto, aproveitando a identificação feita por Betti das patologias próprias do descumprimento do dever de cooperação, o descumprimento do duty to mitigate the loss acaba, em momento reflexo e posterior, violando o dever de cooperação, pela patologia da cooperação recusada.

\subsection{Inviabilidade de um dever de mitigar o dano}

O dever jurídico tem por fonte a norma jurídica, não decorrendo de mera vontade do titular ou de um direito subjetivo ${ }^{145}$, ainda que a existência deste último dependa da presença de um dever. Com efeito, podem existir deveres jurídicos sem que haja direitos subjetivos, mas o oposto não é verdadeiro. O dever de julgar de um juiz ou o dever do cidadão de prestar serviço militar, por exemplo, decorrem da norma jurídica, mas não correspondem a um direito subjetivo ${ }^{146}$.

Quando ocorre a correspondência entre direito subjetivo e dever jurídico, surge a obrigação, pela qual é necessária a dualidade de sujeitos; o ativo, que assume o poder jurídico, e o passivo, que assume o dever jurídico ${ }^{147}$. O passivo sofre a imposição da norma jurídica para que cumpra seu dever jurídico, sob pena de sofrer a sanção prevista naquela ou em um ato ou fato jurídico. Assim, pode-se falar em dever jurídico em sentido estrito, isto é, quando há a obrigação e em dever jurídico lato, quando engloba também aqueles deveres em que não há correspondência com o direito subjetivo.

Portanto, dever jurídico é um comportamento obrigatório, imposto por uma norma jurídica, um negócio jurídico ou um ato jurídico, em que uma pessoa deve prestar a outra para satisfazer o interesse desta, que pode exigir o adimplemento caso não seja

\footnotetext{
${ }^{145}$ Quanto aos direitos subjetivos, vide item 2.1.1.3. infra.

146 GUSMÃO, Paulo Dourado de. Introdução à Ciência do Direito. $2^{\mathrm{a}}$ ed. Rio de Janeiro: Forense, 1960. p. 167.

${ }^{147}$ PEREIRA, Caio Mário da Silva. Instituições de Direito Civil - Vol. I. $21^{\mathrm{a}}$ ed. Rio de Janeiro: Forense, 2005. p. 45.
} 
voluntariamente observado ${ }^{148}$. Neste sentido, a noção de dever jurídico está atrelada à exigibilidade, o que o afasta de um mero dever moral.

De fato, por se tratar de um dever imposto por uma norma (seja lei ou negócio jurídico, etc.), o sujeito ativo tem a possibilidade de exigir o seu cumprimento e aplicar uma sanção ao inadimplente. Afinal, o descumprimento do dever prejudicou o sujeito ativo, impedindo-lhe de satisfazer o poder jurídico que possui. O direito objetivo, então, autoriza o titular do direito subjetivo a acionar os meios à disposição para que sejam tomadas as providências cabíveis.

O duty to mitigate the loss como um dever jurídico é a mais tradicional concepção a qual se pode encontrar. O raciocínio é bastante simples: o credor, com base no princípio da boa-fé, tem o dever de mitigar seu prejuízo, já que a sua inobservância irá posteriormente afetar o devedor em razão do exercício de um dito direito indenizatório do credor.

A própria norma de mitigação foi trazida ao Brasil como se fosse um dever jurídico anexo derivado da boa-fé e do abuso de direito. No ano de 2004, Vera Maria Jacob de Fradera alertou para a necessidade de um dever do credor de mitigar o próprio prejuízo ${ }^{149}$. Seus estudos, inclusive, resultaram no Enunciado no 169 da III Jornada de Direito Civil do Conselho da Justiça Federal ${ }^{150}$. A partir disso, a doutrina nacional também adotou o duty to mitigate the loss como um dever jurídico anexo ${ }^{151}$.

No direito italiano, Betti ${ }^{152}$ já alertava em sua obra para o comportamento correto do credor que, ainda que insatisfeito em sua expectativa, não poderia agir como se estivesse em guerra com o devedor, acrescendo o dano do inadimplemento. E este agir é um dever derivado do princípio da boa-fé, sobretudo do dever jurídico anexo da cooperação. Sendo um dever, o duty to mitigate the loss seria um comportamento que pode ser exigido do credor, já que em razão da confiança gerada pela relação obrigacional, é de

\footnotetext{
${ }^{148}$ GUSMÃO, Paulo Dourado de. Introdução à Ciência do Direito. $2^{\mathrm{a}}$ ed. Rio de Janeiro: Forense, 1960. p. 168.

${ }^{149}$ FRADERA, Vera Maria Jacob de. Pode o credor ser instado a diminuir o próprio prejuízo?. Revista Trimestral de Direito Civil. Rio de Janeiro. v. 5. n. 19. jul./set. 2004. p. 109-119.

${ }^{150}$ Enunciado ${ }^{\circ}$ 169: Art. 422. O princípio da boa-fé objetiva deve levar o credor a evitar o agravamento do próprio prejuízo.

${ }^{151}$ GAGLIANO, Pablo Stolze. Duty to mitigate: Editorial $n^{\circ} 13$. Texto datado de 23/10/2010. Disponível em: http://pablostolze.ning.com/page/editoriais-1. Acesso em 04/03/2012; TARTUCE, Flávio. Direito Civil - Vol. 3 - Teoria Geral dos Contratos e Contratos em Espécie. $8^{a}$ ed. São Paulo: Método, 2013. p. 112.

${ }_{152}$ BETTI, Emilio. Teoria Generale delle Obbligazioni, v. 1, Prolegomeni, Funzione Economico-Sociale dei Rapporti d'Obbligazione. Milano: Giuffrè, 1953.
} 
se esperar uma atuação honesta, leal e uma disposição para o cumprimento do que fora pactuado. Deste entendimento também compartilha a jurisprudência italiana ${ }^{153}$.

Não obstante o entendimento de que o duty to mitigate the loss seja um dever jurídico, não parece ser esta a concepção acertada. A ideia de dever jurídico traz intrinsecamente a qualidade de ser exigível por aquele que sofreu com a inadimplência da outra parte. Em outras palavras, havendo o inadimplemento, o credor pode exigir do devedor o cumprimento da obrigação, sob pena de sofrer as consequências jurídicas legais e previstas nas cláusulas do negócio jurídico celebrado.

Na hipótese de incidência da norma de mitigação, o credor falta com os atos tendentes a evitar ou minimizar os danos decorrentes do inadimplemento do devedor, mas que só ocorreram ou ocorrerão em razão da postura contrária aos seus próprios interesses. O dano só ocorre no patrimônio do próprio credor, o que afasta qualquer prejuízo - ao menos inicialmente ${ }^{154}$ - ao devedor. Neste sentido, o único e maior interessado em mitigar o dano é o próprio credor que está tendo seu patrimônio diminuído. Como a regra é a liberdade de o titular dispor de seus bens livremente, o devedor não dispõe de instrumentos para exigir que o credor interrompa a cadeia de prejuízos.

A ausência de instrumentos hábeis e a relativa liberdade ${ }^{155}$ que alguém desfruta de usar, gozar e dispor de seu patrimônio evidencia a inexigibilidade inerente ao duty to mitigate the loss. Se não cabe ao devedor agir para obrigar o credor a tomar as medidas adequadas para evitar ou minimizar seu dano, isto é, se a conduta não é exigível, não se pode falar em um dever jurídico. Ora, se o credor, que é titular e responsável pelo seu patrimônio, nada faz, não cabe ao devedor, que em nada tem relação com os prejuízos decorrentes da inobservância do duty to mitigate the loss, tomar qualquer atitude para a sua preservação.

A norma de mitigação tem estreita relação com a evitabilidade do prejuízo pelo credor, isto é, a sua possibilidade razoável de evitar ou minimizar o dano. Ao devedor há somente a responsabilidade de restabelecer o equilíbrio entre as partes por consequência de

\footnotetext{
${ }^{153}$ CENDON, Paolo. Commentario al Codice Civile Artt. 2054-2059: Fatti illeciti. Circolazione di veicoli, responsabilità solidale, valutazione, danni non patrimoniali. Milão: Giuffré, 2009.p. 302.

${ }^{154}$ Inicialmente por conta da possibilidade de o credor vir a cobrar indevidamente do devedor os danos havidos, o que poderá levar a prejuízos pela contratação de advogado e demais despesas processuais ou, dependendo do caso, até extraprocessuais (no caso de uma notificação extrajudicial, por exemplo). No entanto, está sendo tratado aqui o momento da incidência da norma de mitigação e não suas consequências. Por isso se diz que os danos ocorrem somente no patrimônio do credor.

${ }^{155}$ A liberdade, por óbvio, não é absoluta, sendo relativizada pelos demais direitos fundamentais de esferas jurídicas alheias e de princípios como a função social.
} 
seu inadimplemento, precisando, para tanto, estarem presentes os pressupostos que o consideram culpado pelo prejuízo. Sendo assim, a causa dos prejuízos é a atitude comissiva ou omissiva do credor que não protegeu o seu próprio patrimônio, quando lhe era possível.

Como o credor não tem que realizar uma prestação ao devedor fundada na norma de mitigação, senão para si mesmo, não existe para este um direito subjetivo. Mais que isto: como é uma atitude voltada do credor para ele próprio, não há como exigir dele a sua adoção. Assim, não se trata o duty to mitigate the loss de uma relação obrigacional, haja vista ser preciso, para a existência de um direito subjetivo, a correlação a um dever jurídico. Tampouco de um dever jurídico lato, pois não está presente a exigibilidade inerente a esta categoria. Logo, sendo inexigível, não se atribuir à norma de mitigação a natureza jurídica de dever. $\mathrm{O}$ devedor não é titular de um poder jurídico de exigir a mitigação e o credor de um dever de observá-la; não há objeto - uma ilógica indenização devida a si mesmo - para que se configure uma prestação.

Assim, enquanto ocorre o prejuízo no patrimônio do credor pela violação à norma de mitigação, nada poderá fazer o devedor, haja vista que só o próprio credor pode decidir se quer que seus bens se mantenham íntegros ou não. Só estará aberta a discussão e intervenção do devedor quando este for cobrado, indevidamente, pelos prejuízos ${ }^{156}$.

Portanto, a noção de dever não se coaduna com as características da doutrina das consequências evitáveis, já que a qualidade de ser exigível é a ele intrínseca. O duty to mitigate the loss não pode ser exigido pelo devedor ${ }^{157}$, pois as consequências gravosas atingem somente o patrimônio do credor. Ou seja: se o credor nada fizer, terá unicamente seu patrimônio violado.

Por tais argumentos, não é adequado compreender o dever jurídico como natureza jurídica do duty to mitigate the loss. É preciso recorrer a outro instituto que o aceite como inexigível e não se submeta a uma análise puramente relacional. Neste cenário é que surge o ônus como uma alternativa adequada, o que seria a natureza jurídica peculiar aventada pelos doutrinadores da common law.

\footnotetext{
${ }^{156}$ Esta situação será abordada detalhadamente no item 4.3., infra.

157 WILLISTON, Samuel; LORD, Richard A. A treatise on the law of contracts. Eagan: Thomson West, 1990. p. 191-193.
} 


\subsubsection{Função delimitadora do exercício de direitos subjetivos}

Outra função exercida pela boa-fé é a de delimitar o exercício de direitos subjetivos para que não se tornem abusivos. Para explicar esta função, é necessário em primeiro lugar esclarecer o que é direito subjetivo, o que, para tanto, podem-se destacar diversas correntes de pensamento.

Windscheid $^{158}$ entende que os direitos subjetivos são somente reflexos de uma ordem jurídica, ou seja, o indivíduo só possui tais direitos porque estes estão objetivamente incorporados. O agir é assegurado pela ordem jurídica, mas a vontade é essencial. Dessa forma, este jurista alemão enxerga o direito subjetivo essencialmente em função do elemento volitivo.

Posteriormente, Ihering ${ }^{159}$ insurge-se contra esta concepção, apresentando um novo conceito de direito subjetivo apoiado em sua visão utilitarista, para o qual o proveito constitui a substância do direito, e não a vontade. O direito subjetivo é um poder jurídico, mas sua finalidade é a satisfação dos interesses humanos. Não diz respeito apenas ao indivíduo, mas também à participação em realizações organizadas. Portanto, o direito subjetivo é um interesse juridicamente protegido.

Outro conceito é aquele concebido por Kelsen ${ }^{160}$, o qual entende que direitos subjetivos são liberdades asseguradas objetiva e juridicamente. A validade do direito é encontrada de maneira deontológica, isto é, as proposições jurídicas é que estabelecem as liberdades de ação. Não há, pois, proteção do direito subjetivo, mas sua previsão no plano deontológico da ordem jurídica. Direito se confunde com Estado. O conceito de direito e moral, dessa forma, são separados, abrindo caminho para uma visão funcionalista dos direitos subjetivos.

Habermas ${ }^{161}$ critica todas estas posições, entendendo que nenhum destes conceitos consegue satisfatoriamente explicar a fonte da legitimidade do direito positivo. Afinal, ao dar autonomia aos direitos subjetivos como desdobramentos morais independentes, não é

\footnotetext{
${ }^{158}$ WINDSCHEID, Bernhard. Lehrbuch des Pandektenrechts. Vol. 2. Frankfurt: Frankfurt a. M. Literarische Anstalt Rütten \& Loening, 1906. parág. 37.

159 IHERING, Rudolph Von. Der Geist des römischen Rechts auf den verschiedenen Stufen seiner Entwicklung. Leipzig: Leipzig Breitkopf und Hartel, 1924. p. 338.

${ }^{160}$ KELSEN, Hans. Teoria Geral do Direito e do Estado. $3^{\mathrm{a}}$ ed. São Paulo: Martins Fontes, 2000. p. 124.

161 HABERMAS, Jürgen. Direito e Democracia; entre facticidade e validade - Volume I. Rio de Janeiro: Tempo Brasileiro, 2003. p. 121-122.
} 
possível fundamentá-los no âmbito da teoria do direito. Por outro lado, ao planificá-los no direito objetivo, colocam-se os direitos subjetivos em plano inferior, com sua legitimidade limitada à legalidade de uma dominação política. A partir disto, elabora sua teoria discursiva do direito, uma construção para solucionar o problema da legitimidade do direito.

Ainda que seja um debate de indiscutível importância, independentemente da corrente adotada, é certo que os direitos subjetivos não são absolutos, podendo sofrer restrições conforme entrem em atrito com outros direitos. É o caso bastante evidenciado nas colisões entre direitos fundamentais que, através do sopesamento, é realizada análise de inexistência de exagerada limitação a um dos direitos, injustificável frente ao objetivo perseguido pela medida ${ }^{162}$.

Partindo desta premissa, é possível compreender que o exercício legítimo de um direito passa a ser irregular quando ultrapassa limites impostos pelas normas jurídicas. É uma amenização do individualismo, posicionando o direito não mais como uma prerrogativa soberana concedida ao indivíduo, mas como prerrogativa concedida ao homem em sociedade.

Dentre os efeitos da função delimitadora, é importante destacar que o princípio da boa-fé acaba atuando em duas frentes, verificáveis pela violação direta a um direito subjetivo de outrem pelo exercício irregular de seu titular que excede seus limites ou pelo óbice de reflexos prejudiciais deste exercício irregular de direito subjetivo através da norma mitigadora.

A violação direta diz respeito aos casos em que há responsabilidade da parte pela violação através de um exercício irregular de um direito. O titular manifestamente excede os limites de seu direito subjetivo, prejudicando esferas outras de direitos. Nasce assim um dever jurídico de reparação dos danos causados, haja vista que a repercussão do exercício que excede os limites atinge os demais indivíduos. É o caso do abuso do direito.

Diferente é o caso da limitação imposta pelo princípio da boa-fé quando a irregularidade do exercício de um direito não prejudica diretamente outrem, mas acaba

162 “O elemento central da teoria dos princípios de Alexy é a definição de princípios como mandamentos de otimização. Para ele, princípios são normas que exigem que algo seja realizado na maior medida possível diante das possibilidades fáticas e jurídicas existentes. Isso significa, entre outras coisas, que, ao contrário do que ocorre com as regras jurídicas, os princípios podem ser realizados em diversos graus. [...] É dessa diferença de estrutura que decorrem as diferentes formas de aplicação das normas jurídicas: a subsunção e o sopesamento". (SILVA, Virgílio Afonso da. Direitos Fundamentais - conteúdo essencial, restrições e eficácia. $2^{\mathrm{a}}$ ed. São Paulo: Malheiros, 2010. p. 46) 
repercutindo negativamente somente na esfera de seu titular. Não há qualquer violação às esferas alheias de direitos subjetivos como ocorre na hipótese anteriormente exposta, limitando-se o dano ao próprio patrimônio do titular em razão de sua atuação em descompasso com a boa-fé.

Nessa hipótese, não nasce para aquele que presenciou o exercício irregular de um direito a responsabilidade indenizatória. Embora tenha havido repercussão negativa na esfera de direitos do titular e tenha por origem a inadimplência de outrem, não foi causada por esta. Foi o próprio titular, com sua conduta incompatível com os ditames da boa-fé, que não agiu com o cuidado necessário para mitigar seus danos.

Neste diapasão é que se pode identificar dentro da função delimitadora de direitos subjetivos do princípio da boa-fé uma norma de mitigação. Afinal, o titular de um direito subjetivo tem o ônus de mitigar o seu dano, sob pena de ter que arcar com todos os prejuízos decorrentes de sua conduta indevida. Embora o assunto seja tratado com mais detalhes adiante, importante desde já ressaltar que a função delimitadora do princípio da boa-fé, para este estudo, tem objetivo além de delimitar o direito subjetivo, mas também de originar o ônus imposto pela norma de mitigação.

Um direito subjetivo vem, obrigatoriamente, atrelado a um dever jurídico. Assim, enquanto o credor tem o poder jurídico de exigir a devida indenização pelos danos havidos por causa do inadimplemento do devedor, este tem o dever jurídico de repará-los. Contudo, o princípio da boa-fé veda a responsabilização do devedor pelos prejuízos que poderiam ter sido evitados pelo credor, impondo o ônus do duty to mitigate the loss, excluindo o direito subjetivo do credor à indenização. Assim, não obstante existir direito subjetivo à indenização pelo inadimplemento, o credor não o possui quando a boa-fé impõe o ônus de mitigação.

Pode-se sintetizar da seguinte forma: enquanto analisada sob o prisma exclusivo do inadimplemento, há o direito subjetivo do credor de ser indenizado e o dever jurídico do devedor de reparação. No entanto, se os danos decorrentes do inadimplemento só são imputáveis ao credor, haja vista que seriam por ele evitáveis, não nasce para ele, exclusivamente neste ponto, direito subjetivo algum de ser indenizado. Consequentemente, tampouco dever jurídico do devedor, pois duty to mitigate the loss faz incidir o ônus da mitigação na hipótese. Tudo isto em razão da função delimitadora do exercício de direitos subjetivos do princípio da boa-fé, que os molda conforme a incidência de uma simples 
limitação - como no caso do abuso do direito - ou limita-os a ponto de nem ao menos existir, criando um ônus para o credor de evitar ou minimizar os danos.

Por isso, a função delimitadora de direitos subjetivos ao mesmo tempo impede condutas abusivas que repercutam na esfera de outrem ou do próprio titular. Contudo, com consequências diferentes: no primeiro caso, há a responsabilização do titular pela indenização dos prejuízos causados à esfera jurídica alheia. No segundo, não há qualquer responsabilidade indenizatória de outrem, pois o titular é quem causou o próprio prejuízo, em inobservância à norma mitigadora imposta por este desdobramento do princípio da boafé. Este último caso é o ponto central deste estudo.

\subsubsection{1. Ônus de mitigação}

Paralelamente aos direitos subjetivos e deveres jurídicos, existe a concepção de ônus, que não se trata de uma obrigação em si, mas o seu descumprimento acarreta prejuízos para aquele que não o observou. Aquele que não se desincumbiu de seu ônus faz com que o ato pretendido não tenha validade. A ausência de registro de documento particular, por exemplo, não o faz ter validade contra terceiros; é preciso cumprir o ônus do registro $^{163}$.

O ônus, como não se trata de uma obrigação, não determina coercitivamente o seu cumprimento, já que o único prejudicado pela sua inobservância é o próprio sujeito que poderia cumpri-lo. Deste modo, não se pode dizer que o ônus é exigível, pois só existe para aquele que tem a incumbência de realizá-lo. A sua sanção, portanto, é a perda da faculdade jurídica a que teria direito se dele se desincumbisse pelo exercício em tempo hábil.

Assim como define Grau ${ }^{164}$, "ônus é um vínculo imposto à vontade do sujeito em razão do seu próprio interesse". Trata-se de um instrumento que o ordenamento jurídico impõe para que um sujeito adote determinado comportamento se não quiser arcar com as consequências que lhe são prejudiciais ou se quiser alcançar determinada vantagem pela aquisição ou conservação de um direito ${ }^{165}$.

\footnotetext{
${ }^{163}$ REALE, Miguel. Lições Preliminares de Direito. 29a ed. São Paulo: Saraiva, 2001. p. 265.

${ }^{164}$ GRAU, Eros Roberto. Nota sobre a distinção entre Obrigação, Dever e Ônus. Revista da Faculdade de Direito da Universidade de São Paulo. v. 77, p. 177-183, 1982. p. 181.

${ }^{165}$ Idem. ibidem.
} 
Couto e Silva, reconhecendo não ser esta a melhor expressão, diz que o que certos juristas chamam de deveres para consigo mesmo são, na verdade, o ônus. Só que não podem ser deveres jurídicos, "porque dever é sempre dever para com alguém ${ }^{166, "}$

\begin{abstract}
O ônus e o dever são figuras distintas em pelo menos dois aspectos: (i) o dever implica um correlato direito de outro sujeito, ou seja, é uma conduta que a lei prescreve no interesse de outrem, enquanto que o ônus é estabelecido no interesse do próprio onerado; (ii) o descumprimento do dever pode implicar a incidência de uma sanção, ao passo que a inobservância do ônus apenas faz com que o onerado eventualmente perca a chance de desfrutar de uma situação melhor ${ }^{167}$.
\end{abstract}

Esta diferenciação entre ônus e dever jurídico também foi trabalhada no direito alemão e no direito suíço, embora por outras nomenclaturas. No direito alemão, as obrigações se diferenciam em razão de sua intensidade. As Obliegenheiten são as de menor intensidade, em contraposição às Pflichten. A inobservância das Obliegenheiten leva à perda de uma vantagem jurídica, não podendo quem quer que seja exigir o seu cumprimento, diferente do que ocorre com as Pflichten, que podem gerar uma execução forçada ou, se for o caso, convertidas em perdas e danos ${ }^{168}$.

A ideia da Obliegenheit surgiu no sistema alemão de seguros. O segurado tinha a obrigação de avisar sem atraso o sinistro e deveria mitigar seus danos. Com o descumprimento desta obrigação, a seguradora não tinha meios para acionar o Judiciário, já que não há exigibilidade na mitigação. Dessa maneira, o caminho mais simples era não conceder indenização nos casos de descumprimento da norma de mitigação ${ }^{169}$.

Transportando para o direito brasileiro, as Obliegenheiten correspondem ao ônus; as Pflichten, às obrigações. O direito suíço, por sua vez, desenvolveu a ideia de incombance - derivado de incumbere, no sentido de pesar, onerar -, que nada mais é do que a mesma acepção de Obliegenheit e, por conseguinte, de ônus ${ }^{170}$. O artigo 44 do Código Civil suíço (ZGB) traz a possibilidade de o tribunal reduzir equitativamente a

\footnotetext{
${ }^{166}$ SILVA, Clóvis Couto e. A obrigação como processo. São Paulo: José Bushatsky, 1976. p. 120.

${ }^{167}$ WAMBIER, Luiz Rodrigues et al. Curso Avançado de Processo Civil v. 1: Teoria Geral do Processo e Processo de Conhecimento. 10ª ed. São Paulo: Revista dos Tribunais, 2008. p. 457.

${ }^{168}$ LOPES, Christian Sahb Batista. A mitigação dos prejuízos no direito contratual. Belo Horizonte, 2011. Tese (Doutorado em Direito). Faculdade de Direito da Universidade Federal de Minas Gerais. p. 182-183.

169 CORDEIRO, António Manuel da Rocha e Menezes. Tratado de direito civil português: introdução, doutrina geral, negócio jurídico. v. 1, t. 1., Coimbra: Almedina. p. 359.

${ }^{170}$ LOPES, Christian Sahb Batista. A mitigação dos prejuízos no direito contratual. Belo Horizonte, 2011. Tese (Doutorado em Direito). Faculdade de Direito da Universidade Federal de Minas Gerais. p. 182-183.
} 
indenização quando os danos poderiam ter sido minimizados pela parte. Esta ideia também pode ser encontrada no direito belga ${ }^{171}$.

No Brasil, a concepção de ônus foi muito melhor desenvolvida no direito processual, partindo de todo o entendimento sedimentado nos estudos acerca do ônus da prova e da postura das partes na relação processual. E neste ramo os exemplos são inúmeros.

\begin{abstract}
Ninguém pode obrigar, por exemplo, o réu a contestar, a parte a arrolar testemunhas, o vencido a recorrer. Mas existe o ônus processual de fazê-lo, no momento adequado, pois, se o réu não contesta, são havidos como verdadeiros os fatos que arrolou o autor contra ele (art. 319); se a parte não apresenta prova do fato alegado, não será ele levado em conta pelo juiz (art. 333); se o vencido não recorre em tempo útil, a sentença transita em julgado e torna-se imutável e indiscutível (art. 467) etc ${ }^{172}$.
\end{abstract}

Apenas recentemente o ônus se estendeu para os outros ramos do Direito ${ }^{173}$. Essa extensão foi decisiva para a correta compreensão de institutos como o duty to mitigate the loss, pois somente a partir daí é que a natureza jurídica se tornou adequada ao seu funcionamento. A norma de mitigação, consoante visto no item anterior, não é exigível, já que não se trata de uma prestação do credor ao devedor. O dano se propaga no patrimônio do próprio credor, sendo que este é o que se encontra na melhor posição de evitá-lo ou minimizá-lo. Por isso, na ausência de um dever jurídico, cabe ao credor o ônus de mitigar seu prejuízo, senão terá que arcar com todos eles, sem direito à indenização pelo devedor.

A diferença entre ônus, de um lado, e deveres e obrigações, de outro lado, está em que a parte é livre de adimplir ou não o primeiro, embora venha a sofrer dano jurídico em relação ao interesse em jogo no processo. [...] É que, nos casos de ônus, está em jogo apenas o próprio direito ou interesse da parte, enquanto, nos casos de deveres ou obrigações, a prestação da parte é direito de outrem ${ }^{174}$.

171 FAUVARQUE-COSSON, Bénédicte; MAZEAUD, Denis. European Contract Law: Materials for a Common Frame of Reference: Terminology, Guiding Principles, Model Rules. Munique: European Law Publishers, 2008. p. 562.

${ }^{172}$ THEODORO JÚNIOR, Humberto. Curso de Direito Processual Civil - Teoria Geral do Direito Processual Civil e Processo de conhecimento - Vol. I. $47^{\mathrm{a}}$ ed. Rio de Janeiro: Forense, 2007. p. 82.

${ }^{173}$ REALE, Miguel. Lições Preliminares de Direito. 29a ed. São Paulo: Saraiva, 2001. p. 265.

174 THEODORO JÚNIOR, Humberto. Curso de Direito Processual Civil - Teoria Geral do Direito Processual Civil e Processo de conhecimento - Vol. I. 47 a ed. Rio de Janeiro: Forense, 2007. p. 82. 
Alguns autores tratam ônus como sinônimo de encargo ${ }^{175}$. Todavia, especificamente no ramo do Direito Civil, o uso desta expressão se torna tormentosa em razão da existência do encargo como elemento acidental do negócio jurídico.

Um elemento acidental subordina o negócio jurídico a fatores exógenos ${ }^{176}$. Não basta a manifestação de vontade das partes simplesmente - com o preenchimento dos elementos essenciais -, é preciso haver a incidência de um elemento externo, estabelecido na cláusula acidental, para que o negócio produza efeitos ou, até mesmo, exista. Esta cláusula também não pode ser presumida, mas determinada consensualmente pelas partes. Tanto é verdade que o artigo 137 do Código Civil considera não escrito o encargo ilícito ou impossível, isto é, pressupõe que houve adoção expressa pelos pactuantes do elemento acidental. Neste sentido, sendo necessário o elemento volitivo expresso, não há como recepcionar a ideia de um encargo que se estabelece por si só pelo simples fato de se ter celebrado um negócio jurídico.

Além disso, o encargo como elemento acidental do negócio jurídico tem o efeito de, desde logo, fazer com que o beneficiário adquira e exercite o direito, consoante o artigo 136 do Código Civil. O beneficiário deverá cumprir seu encargo sob pena de revogação da liberalidade, mas isto não impede - salvo se assim estipular o disponente - de que aquele adquira e exercite seu direito imediatamente.

Confundir o encargo com o significado de ônus com o encargo como elemento acidental de um negócio jurídico faz com que a norma de mitigação seja necessariamente pactuada para produzir efeitos, independentemente se derivada da boa-fé. A única maneira de fazer com que haja incidência do duty to mitigate the loss seria a partir de uma relação negocial, já que num caso puro de responsabilidade civil inexiste pacto prévio passível de constar uma cláusula de encargo.

Ademais, haveria uma contradição lógica no artigo 136, já que o credor adquiriria desde logo o direito à indenização, sendo este revogável se não cumprir o encargo, no caso, da mitigação. Ora, o credor não adquire direito algum à indenização; pelo contrário, este direito nem chega a existir, já que é incumbência sua evitar ou mitigar seus danos. Logo, não há como exercer imediatamente um direito que nem ao menos chega a existir. É

\footnotetext{
${ }^{175}$ DIAS, Daniel Pires Novais. O duty to mitigate the loss no Direito Civil brasileiro e o encargo de evitar o próprio dano. Revista de Direito Privado. Ano 12. n. 45. jan./mar. 2011. p. 122; DIDIER JÚNIOR, Fredie. Curso de Direito Processual Civil Vol. 2. $4^{a}$ ed. São Paulo: Revista dos Tribunais, 2009. p. 73; REALE, Miguel. Lições Preliminares de Direito. 29a ed. São Paulo: Saraiva, 2001. p. 265.

${ }_{176}$ PEREIRA, Caio Mário da Silva. Instituições de Direito Civil - Vol. I. $21^{\mathrm{a}}$ ed. Rio de Janeiro: Forense, 2005. p. 553.
} 
inadmissível que adquira um direito temporário de reparação que, através da cláusula geral da boa-fé, será afastado pelo magistrado na normatização do caso concreto ${ }^{177}$. Por toda a confusão gerada, é melhor a manutenção da expressão "ônus" ao invés de "encargo".

$\mathrm{O}$ enquadramento do ônus como natureza jurídica do duty to mitigate the loss ultrapassa as dificuldades da adoção do dever jurídico. Decorrendo danos para o credor em razão do inadimplemento do devedor, aquele terá o ônus de mitigá-los caso sejam por ele evitáveis. Se assim agir, o credor poderá ser indenizado dos gastos que teve para mitigar. Não agindo desta forma, terá que arcar com o prejuízo, sem poder exigir do devedor a indenização.

Cabia somente ao credor mitigar o prejuízo e assim não agiu. Logo, sofrerá a desvantagem de arcar com o que perdeu; ou, visto por outro ângulo, deixará de obter a vantagem de ser indenizado pelos gastos que teve por não conservar o seu direito. Esta noção se encaixa perfeitamente no conceito de ônus apresentado alhures: a norma de mitigação é o instrumento do ordenamento jurídico, o ônus, que, caso não seja observada, fará com que o credor não recupere o prejuízo que sofreu, isto é, não atrairá para si a vantagem econômica pela conservação de seu direito.

O ônus não é exigível: por atender a um interesse próprio, terceiros não sofrem diretamente a repercussão da desvantagem da sua inobservância. Não há, pois, sanção, assim como ocorre no duty to mitigate the loss: quando da sua incidência, se não for cumprido, deixará o credor de ser indenizado pelos prejuízos que deixou de evitar quando podia.

Além disso, como a atuação depende somente do credor e o dano é relativo ao seu patrimônio, não poderá o devedor exigir o cumprimento do ônus de mitigação, restandolhe apenas alegar a matéria numa eventual ação de cobrança como pressuposto de exigibilidade processual ${ }^{178}$.

Por isso que o não-cumprimento do ônus não acarreta, para o sujeito, sanção jurídica, mas tão-somente uma certa desvantagem econômica: a não obtenção da vantagem, a não satisfação do interesse ou a não realização do direito pretendido. Já o não-cumprimento do dever — ou da obrigação — acarreta sanção jurídica pára o sujeito. Neste último caso, o interesse a cuja tutela aproveita o cumprimento do dever é alheio à pessoa do sujeito a ele vinculado; no primeiro

\footnotetext{
${ }^{177}$ Conforme visto no item 2.1. supra.

${ }^{178}$ Vide Capítulo 3, item 3.3. infra.
} 
caso, o interesse a que respeita a vinculação pelo ônus é do próprio sujeito vinculado $^{179}$.

A inexigibilidade, contudo, não se confunde com ausência de imposição pelo ordenamento jurídico do cumprimento do ônus. O ônus da mitigação impõe uma norma de conduta fundada no princípio da boa-fé, pela qual preza pela hígida continuidade da relação jurídica. Dessa maneira, se espera que o credor aja de maneira leal e mitigue seus danos, para que não desestabilize sua relação com o devedor e sofra as consequências da inobservância da norma de mitigação.

\subsection{O ônus da mitigação e o dever de cooperação}

O dever de cooperação implica na ideia de colaboração e assistência mútua entre as partes. Havendo uma relação jurídica, seja ela contratual ou extracontratual, o princípio da boa-fé impõe que ambas as partes se unam para realizar o objetivo em comum. Contudo, nem sempre as expectativas são atendidas e há uma quebra de confiança no vínculo, o que pode resultar numa nova negociação para reestruturação da relação ou, se não for mais possível, numa quebra total, ocasionando uma rescisão ou inadimplemento.

Especificamente no caso do inadimplemento, podem ocorrer danos - ou estar na iminência de ocorrerem - os quais cabem ao credor evitar ou mitigar em razão do ônus que possui consoante impõe o princípio da boa-fé. Sem sombra de dúvida, a mitigação se traduz à primeira vista como uma cooperação do credor, pois impede o agravamento do seu prejuízo e, de maneira reflexa, obsta uma futura lide com o devedor sobre a responsabilidade e definição do valor indenizatório. Então, poderia surgir a indagação se o ônus da mitigação não é simplesmente um desdobramento do dever de cooperação, próprio de uma situação com pressupostos específicos, assim como ocorre com a proibição do venire contra factum proprium em relação ao abuso de direito e a boa-fé.

Como dito, a impressão da mistura entre ambos os institutos é somente à primeira vista. Numa análise mais atenta, nota-se que cada um deles possui particularidades próprias que os distanciam, ainda que, teleologicamente, busquem a harmonia entre as partes.

\footnotetext{
${ }^{179}$ GRAU, Eros Roberto. Nota sobre a distinção entre Obrigação, Dever e Ônus. Revista da Faculdade de Direito da Universidade de São Paulo. v. 77, p. 177-183, 1982. p. 181
} 
A diferença já começa na natureza jurídica. Enquanto a norma de mitigação é um ônus, o dever de cooperação é um dever jurídico. Sem repetir toda a fundamentação dos argumentos já traçados anteriormente, o dever de cooperação é exigível pela parte contrária, enquanto que a mitigação não é. O ônus de mitigação não se traduz numa prestação devida de uma parte a outra, enquanto que o dever de cooperação sim. $\mathrm{O}$ descumprimento do dever de cooperação atinge diretamente a parte contrária, enquanto que a inobservância do ônus atinge apenas reflexamente.

O dever de cooperação atinge todas as etapas de uma relação jurídica, e isto fica mais evidente numa relação contratual, que possui negociações preliminares e período póscontratual. Não se trata de um dever a ser visto de forma fragmentada, mas que engloba a totalidade do relacionamento das partes. O ônus da mitigação, por sua vez, ainda que possa existir em todas as etapas, depende da presença de requisitos específicos para sua incidência. Assim, não há falar em norma de mitigação se inexiste inadimplemento, dano imputável ao devedor e se o prejuízo poderia ser razoavelmente evitado ou mitigado pelo credor.

Não é igual à hipótese da vedação aos atos contraditórios, consoante referenciado acima, já que estes podem ser exigidos a qualquer momento pela parte contrária assim que ocorre a violação ou a iminência da sua ocorrência. Os deveres fundados na boa-fé podem ser exigidos a todo o momento pela parte contrária, impedindo que os pressupostos específicos se configurem e haja uma crise na relação jurídica. $\mathrm{Na}$ incidência da norma de mitigação, nada pode fazer a parte contrária para que coercitivamente faça com que o credor cumpra seu ônus. Mesmo que o devedor preveja o preenchimento de todos os pressupostos de existência do duty to mitigate the loss, nada poderá fazer para que o credor evite ou mitigue o prejuízo, a não ser, no máximo, avisá-lo, cumprindo um dever de informação. Mesmo assim, caberá ao credor decidir se assume os danos ou toma as medidas adequadas.

A incidência do dever de cooperação também é diferente daquela do ônus de mitigação. Enquanto o duty to mitigate the loss está focado nos prejuízos evitáveis após o inadimplemento, o dever de cooperação está focado na facilitação do adimplemento, na manutenção da prestação como algo do interesse da parte contrária e na realização das prestações da melhor maneira e de forma mais simples. Então, se o credor está ocupado com a mitigação dos danos evitáveis, o devedor deve continuar cumprindo o dever de cooperação, não propiciando o surgimento de novos prejuízos, sobretudo inevitáveis pelo 
credor. Na mesma esteira, ao credor não é permitido violar o dever de cooperação só porque teve que arcar com a mitigação. Portanto, o que não se envolve exclusivamente com o ônus de mitigação ainda está submetido ao dever de cooperação.

Retomando os ensinamentos de Betti explanados no item 2.1.1.2.5.2., o inadimplemento contrário ao ordenamento jurídico configura uma cooperação recusada, podendo se converter em perdas e danos, juros, atualização monetária e honorários advocatícios. O inadimplemento é uma violação ao dever de cooperação e, simultaneamente, o primeiro pressuposto de existência do duty to mitigate the loss. Neste sentido, fica incoerente tratar ambos os institutos como se um fosse desdobramento do outro, já que a violação de um (que traz as devidas consequências jurídicas) é somente o preenchimento do pressuposto de outro (que não atrai qualquer consequência jurídica senão aguardar o preenchimento dos demais pressupostos).

A violação ao dever de cooperação também pode ocorrer nos reflexos da incidência da norma de mitigação. O ato do credor de cobrar pelos prejuízos decorrentes do inadimplemento, mas que poderia ter evitado é violador da boa-fé, especificamente do dever de cooperação. Afinal, mesmo sabendo que os prejuízos não são de responsabilidade do devedor, mesmo assim cobra-o indevidamente, postura que com certeza não converge com a ideia de colaboração.

Logo, dever de cooperação não se confunde com o ônus de mitigação. O dever de cooperação incide sobre toda a relação jurídica. O ônus de mitigação, por sua vez, atinge somente um momento específico, em que restam preenchidos todos os pressupostos de existência. O dever de cooperação, por conseguinte, é muito mais amplo que o ônus de mitigação, incidindo em um campo mais abrangente de hipóteses, ao contrário do duty to mitigate the loss que incide em uma situação específica.

\subsection{O abuso de direito}

Também seria possível questionar o instituto do abuso de direito como um possível referencial teórico para o duty to mitigate the loss. Neste sentido, o descumprimento da norma de mitigação pelo credor seria um exercício abusivo do direito à indenização, pois pretender ser indenizado pelo prejuízo que teria a incumbência de evitar ou mitigar é exercer irregularmente seu direito, ultrapassando seus limites. 
A própria nomenclatura da teoria do abuso de direito já sustenta controvérsias: "a ideia de abuso já é a negação do direito, enquanto o conceito de direito repele a noção de abuso $^{180}$ ". O exercício de um direito teve originalmente como sustentáculo a sua possibilidade de desfrute amplo, admitindo-se que o seu limite é o próprio conteúdo do direito, independentemente dos problemas que poderia acarretar para outrem ${ }^{181}$. No entanto, com a própria convivência imposta pela vida em sociedade, a conciliação do exercício do direito com a esfera jurídica alheia criou a necessidade de fixação de limites.

Embora seja possível encontrar algumas passagens no direito romano em que se pode extrair parcialmente elementos do exercício abusivo de direito ${ }^{182}$, é certo que nas regras se encontram tantas exceções que a norma abstrata de convivência nunca se mostrou como um empecilho. Ao contrário, as regras parecem muito mais excepcionar os limites para permitir que o titular do direito ultrapasse os limites de seu exercício. No período da Idade Média também não se encontra o abuso de direito como um instituto autônomo, mas previsão de hipóteses típicas em que se encontrava presente a atividade realizada com a intenção de prejudicar $^{183}$, nomeada de aemulatio.

Diz-se, então, que a teoria do abuso de direito surgiu realmente na jurisprudência francesa no século XIX, recebendo este nome pelo belga Laurent, sendo que os primeiros julgados foram realizados logo após a edição do Código Civil francês de $1804^{184}$. Na ausência de uma construção teórica prévia do abuso de direito, o direito francês passou a desenvolvê-lo como um instituto autônomo a partir da noção dos atos emulativos. Neste diapasão, surge a concepção subjetiva do abuso do direito, em que se faz necessária a intenção do titular do direito em exercício abusivo de prejudicar alguém ou que da sua atuação não decorra qualquer utilidade.

O direito alemão também adotou a concepção subjetiva do abuso de direito no BGB. O §226 proibia o exercício de um direito se tivesse como único propósito causar dano a outrem. Como o dispositivo exigia o propósito de prejudicar, a sua aplicação foi mínima, buscando o direito alemão outro fundamento legal para a teoria do abuso de direito. A primeira solução encontrada foi utilizar o $\$ 826$ do BGB, o qual obrigava a

\footnotetext{
${ }^{180}$ PEREIRA, Caio Mário da Silva. Instituições de Direito Civil - Vol. I. $21^{\mathrm{a}}$ ed. Rio de Janeiro: Forense, 2005. p. 671.

${ }^{181}$ Idem, ibidem. p. 671-672.

182 "Nullus videtur dolo facere, qui suo iure utitur". (Digesto, Livro 50, tit. 17, fr. 55), "Nemo damnum facit, nisi qui id fecit, quod facere ius non habet". (Digesto, Livro 50, tit. 17, fr. 151)

183 CORDEIRO, Antonio Manuel da Rocha e Menezes. Da Boa Fé no Direito Civil. $4^{\mathrm{a}}$ reimpressão. Coimbra: Almedina, 2001. p. 674.

${ }^{184}$ Idem, ibidem. p. 671.
} 
reparar os danos aquele que causasse dolosamente danos a outrem atentando contra os bons costumes. Também não foi bem sucedida, já que a restrição era ainda maior tendo em vista que a única solução possível era a reparação dos danos, sem possibilidade de o prejudicado escolher a melhor alternativa para o seu caso como, por exemplo, a cessação do exercício abusivo. Foi então que, diante da insuficiência do $\$ 826$ que houve uma aproximação do abuso de direito com o instituto da boa-fé, o direito alemão começou a adotar como fundamento legal o $\$ 242$ do BGB, que obriga o devedor a executar a prestação tal como exige a boa-fé e com consideração dos costumes do tráfego ${ }^{185}$.

É praticamente impossível determinar o momento em que o ato foi praticado com a intenção de prejudicar, ao ser originalmente um estado de espírito, ainda que exteriorizado $^{186}$. Como leciona Zanetti, no âmbito das negociações é ainda mais tormentosa a prova da intenção de prejudicar ou do exercício do direito sem efetivo interesse dada a potencial participação de diversas pessoas ou que a ruptura se deu pelo surgimento de outro negócio mais interessante ${ }^{187}$. Por isso que tanto no direito alemão quanto no desenvolvimento de outras legislações, o abuso do direito na sua concepção exclusivamente subjetiva foi sendo paulatinamente abandonado. E no que tange especificamente o duty to mitigate the loss, Lopes assim observa:

\begin{abstract}
Em casos limite, pode-se vislumbrar que o credor intencionalmente aumente os danos que ele próprio sofra a fim de obter alguma vantagem indevida do devedor sob a ameaça de uma indenização substancial, atuando de maneira oportunística. Seu objetivo seria, então, causar prejuízo ao devedor, podendo-se dizer que agiu em abuso do direito, mesmo se o encara sob o ponto de vista subjetivo. Todavia, esses casos são excepcionais. Na maioria das hipóteses, o credor apenas não se preocupa em mitigar os danos porque sabe que esses têm como causa o inadimplemento do devedor que, portanto, deverá indenizá-los. Ao exercer o direito à reparação, portanto, não abusa, mas age no exercício regular do direito de ter seu patrimônio restaurado. Assim, não servindo a teoria do abuso do direito, no seu aspecto subjetivo, para explicar a generalidade dos casos em que se exige a conduta de minimização dos prejuízos por parte do credor, não poderá ser adotada como fundamento da norma de mitigação ${ }^{188}$.
\end{abstract}

Não obstante, o direito brasileiro consagra no parágrafo $2^{\circ}$ do artigo 1.228 a concepção subjetiva ao tratar como defesos os atos que não trazem ao proprietário

\footnotetext{
${ }^{185}$ Idem, ibidem. p. 685-697.

${ }^{186}$ ZANETTI, Cristiano de Sousa. Responsabilidade pela Ruptura das Negociações. $1^{\text {a }}$ ed. São Paulo: Juarez de Oliveira, 2005. p. 92.

${ }^{187}$ Idem, ibidem.

${ }^{188}$ LOPES, Christian Sahb Batista. A mitigação dos prejuízos no direito contratual. Belo Horizonte, 2011.

Tese (Doutorado em Direito). Faculdade de Direito da Universidade Federal de Minas Gerais. p. 156.
} 
qualquer comodidade, ou utilidade, e sejam animados pela intenção de prejudicar outrem. Só que se refere somente ao direito de propriedade, mantendo-se em harmonia com a concepção objetiva prevista no artigo 187, a qual se dirige a todo o direito privado.

Por tais críticas é que atrelar o abuso de direito ao dispositivo que consagra a boa-fé no direito alemão foi essencial para adequar o critério de aferição do comportamento abusivo. As concepções de confiança e lealdade (Treu und Glauben) alçadas pela boa-fé fazem com que os indivíduos sigam padrões de comportamento objetivamente definidos. A função delimitadora do exercício de direitos subjetivos se relaciona diretamente com o exercício regular do direito.

Atento a este recurso, Maridakis desenvolveu a redação do artigo 281 do Código Civil grego realizando a adequada correção dos elementos que caracterizariam o abuso de direito. Assim, aproveitando-se da codificação suíça e da doutrina alemã, fez referência aos bons costumes e à boa-fé. Do projeto franco-italiano das obrigações, o fim social e econômico do direito. Por fim, do artigo $2 / 2$ do Código Civil suíço (ZGB) ${ }^{189}$, a proibição do exercício do direito à ultrapassagem manifesta dos limites que lhe são impostos ${ }^{190}$.

Tanto o Código Civil português em seu artigo $334^{191}$ quanto o atual Código Civil brasileiro em seu artigo 187 realizam o mesmo tipo de tratamento da legislação grega e do esforço doutrinário alemão. Concebem, objetivamente, que se considera abusivo o exercício de um direito quando o seu titular excede manifestamente os limites impostos pela boa fé, pelos bons costumes, pelo seu fim social ou econômico ${ }^{192}$.

Existem, então, quatro estruturas que, quando o exercício excede os limites por eles impostos, é considerado abusivo: fim social, fim econômico, bons costumes, e boa-fé. A apuração de cada um deles será importante para definir se o abuso de direito servirá como fundamento do duty to mitigate the loss.

\footnotetext{
${ }^{189}$ Artigo 2/2: O abuso manifesto de um direito não é protegido pela lei. (tradução livre do original)

190 CORDEIRO, Antonio Manuel da Rocha e Menezes. Da Boa Fé no Direito Civil. $4^{\mathrm{a}}$ reimpressão. Coimbra: Almedina, 2001. p. 715.

${ }^{191}$ Artigo 334 Abuso do direito

É ilegítimo o exercício de um direito, quando o titular exceda manifestamente os limites impostos pela boa fé, pelos bons costumes ou pelo fim social ou económico desse direito.

192 Cumpre salientar que o Código Civil de 1916 não trazia uma regra específica acerca do abuso de direito. O instituto era extraído a partir de uma leitura a contrario sensu do artigo 160, inciso I, "sob o argumento de que, se não é ato ilícito o dano causado no exercício regular de um direito, é abusivo o exercício irregular" (PEREIRA, Caio Mário da Silva. Instituições de Direito Civil - Vol. I. 21 a ed. Rio de Janeiro: Forense, 2005. p. 674).
} 
Quanto aos fins econômicos e sociais, a sua inclusão como estrutura de identificação de um exercício abusivo de direito não é livre de críticas. A referência a tais fins exprimem a impossibilidade de uma liberdade total de exercício do conteúdo dos direitos subjetivos, não em confronto com outros direitos subjetivos específicos, mas limitados pela função social e econômica que as faculdades jurídicas estão submetidas.

Neste sentido, falar em fins econômicos e sociais para impedir abusos se mostra importante para um contexto extremamente liberal, em que o ordenamento jurídico não transmite segurança na aplicação das normas jurídicas. Em um plano em que há intervenção no mercado, tratar de finalidades econômicas e sociais é realizar uma análise particular, caso a caso, sem ter como parâmetro uma norma geral. Afinal, o exercício abusivo ocorre com a violação de uma norma jurídica, e os fins sociais e econômicos servem de parâmetros de aferição de funcionamento da relação jurídica em tela. Não trata, pois, do conteúdo do abuso de direito, mas da funcionalização em atenção às finalidades que ultrapassam o interesse particular.

\begin{abstract}
A tese aqui defendida da inexistência, como princípio dispositivo, de uma função social e económica, não impede a sua presença como factor de política legislativa, enquanto regras de solidariedade social, guarnecidas, muitas vezes, a nível constitucional, devem levar o intérprete-aplicador a, aquando da ponderação de situações singulares, ter em conta os efeitos dos exercícios individuais, nas sua projecções sociais e económicas ${ }^{193}$.
\end{abstract}

Assim sendo, não tratando propriamente de estruturar o abuso de direito, não há falar igualmente de base para a norma de mitigação.

No tocante aos bons costumes, sua origem está nos boni mores romanos, os quais separavam as normas morais das regras jurídicas, serviço atribuído aos censores que entregavam o resultado de seu trabalho aos pretores ${ }^{194}$. Diferente da concepção romana da bona fides, a qual denotava fidelidade ao pactuado ${ }^{195}$.

193 CORDEIRO, Antonio Manuel da Rocha e Menezes. Da Boa Fé no Direito Civil. $4^{\mathrm{a}}$ reimpressão. Coimbra: Almedina, 2001. p. 1232.

${ }^{194}$ Idem, ibidem, p. 1210.

195 MARTINS-COSTA, Judith. A Boa-fé no Direito Privado: sistema e tópica no processo obrigacional. São Paulo: Revista dos Tribunais, 2000. p. 124. Pela saudação em que entrelaçavam as mãos direitas, firmava-se um compromisso entre as partes, acompanhados do juramento (ius iurandum) que resultava na aliança (foedus). Este compromisso era feito perante a deusa Fides - expressão que originou as palavras "fé”, "confiança" e "fidelidade" -, que obrigava um agir leal e honesto daqueles que o praticaram. Havia, então, a criação de um vínculo obrigatório entre os pactuantes que os impediria de agir de maneira diversa daquela 
Os bons costumes são normalmente encontrados nas legislações sem determinar um modelo de comportamento, apenas delimitando o campo de atuação permitida. Conforme destaca Cordeiro ${ }^{196}$, só no dispositivo português que trata do abuso de direito (e, portanto, no artigo 187 do Código Civil brasileiro) é que os bons costumes aparecem como uma forma de atuação, assim como ocorre com a boa-fé. Todavia, esta aproximação não se desdobra em uma convergência de significados. Quando se fala de bons costumes, se está diante de normatização própria da Moral social, compreendendo certos comportamentos limitados pela tradição sem previsão legal expressa, mas que vigoram como imperativo da vida em sociedade de maneira genérica. Já a boa-fé prescreve comportamentos consubstanciados na lealdade e confiança em relações específicas, um proceder próprio para a hipótese em que ela incide. Portanto, os bons costumes não se mostram adequados como estrutura.

Sobra então o elemento da boa-fé que, conforme assentado antes, transmite as ideias de lisura, probidade, honestidade, confiança e lealdade. Ora, se a boa-fé estrutura o abuso de direito, logo fundamentar o duty to mitigate the loss nele seria inadequado, já que a verdadeira raiz se encontra na própria boa-fé. Exercitar abusivamente um direito é agir de má-fé, haja vista que houve desrespeito aos deveres anexos que o princípio da boa-fé implica, sobretudo da cooperação. O titular do direito em exercício irregular não realiza a sua obrigação da melhor maneira, tampouco de forma simples ${ }^{197}$. Igualmente, não observou a delimitação de direitos subjetivos também imposta pela boa-fé. Dessa maneira, entende-se que o abuso de direito nada mais é do que um dos desdobramentos do princípio da boa-fé, ou seja, uma das diversas facetas pela qual ele aparece no ordenamento jurídico.

\footnotetext{
O essencial do exercício inadmissível de posições jurídicas é dado pela boa fé; aos bons costumes e à função social e econômica dos direitos, [...] cabe um papel diferente ${ }^{198}$.
}

Não se pode dizer, então, que a noção de exercício abusivo de um direito, no Brasil, se aproxima da concepção francesa. Afinal, no direito francês, a responsabilidade civil traz

prometida ou deixasse de cumprir sua prestação. Não havia melhor forma de agraciar Fides senão o cumprimento do que fora prometido.

196 CORDEIRO, Antonio Manuel da Rocha e Menezes. Da Boa Fé no Direito Civil. $4^{\text {a }}$ reimpressão. Coimbra: Almedina, 2001. p. 1213-1214.

${ }^{197}$ Vide item 2.1.1.2.5.1. supra.

198 CORDEIRO, Antonio Manuel da Rocha e Menezes. Da Boa Fé no Direito Civil. $4^{\mathrm{a}}$ reimpressão. Coimbra: Almedina, 2001. p. 901. 
como consequência unicamente a reparação por perdas e danos, guiada pelo princípio da reparação integral ${ }^{199}$. A formulação brasileira mais se aproxima da germânica e da portuguesa, que estampa o abuso de direito como uma cláusula geral, em que o juiz determinará a medida mais adequada para a reparação do prejuízo.

O abuso de direito como fundamento também pode ser combatido por outro viés, posterior ao descumprimento do duty to mitigate the loss. Consoante será desenvolvido adiante, o funcionamento da norma de mitigação não permite que surja um direito à indenização do credor pelos danos agravados, já que, desde o início, o devedor só é responsável por aquilo que era inevitável e pelo prejuízo causado pela inexecução de sua obrigação. No duty to mitigate the loss, não há direito à indenização pelo o que era evitável, pois o credor tem que mitigar ou evitar o agravamento do seu prejuízo. Neste diapasão, é contraditório afirmar que ao exigir a indenização, o credor está exercendo abusivamente seu direito, já que este não há. Não há como abusar de um direito que não possui.

\subsubsection{A proibição do venire contra factum proprium}

Também é apontada como possível fundamento a proibição do venire contra factum proprium, também chamada de teoria dos atos próprios. Traduz-se como um inadmissível comportamento contraditório àquele anteriormente realizado, sendo que o primeiro havia despertado para a outra parte a legítima confiança de que não ocorreria o segundo. Como requisito para sua configuração, portanto, é preciso que a mesma pessoa realize dois comportamentos lícitos e diferidos no tempo, com o detalhe que o segundo contraria o primeiro, traindo a confiança depositada pela outra parte. A contradição existe tanto quando se pratica um ato após ter externado que não ocorreria como quando não se executa algo que se indicia que seria feito ${ }^{200}$.

Com relação ao duty to mitigate the loss, a proibição do venire contra factum proprium incidiria da seguinte forma: o credor, em seu primeiro comportamento, admitiria sofrer prejuízos agravados em seu patrimônio com o inadimplemento do devedor e aquelas

\footnotetext{
${ }^{199}$ LE PAUTREMAT, Solène. Mitigation of damage: a French perspective. International and Comparative Law Quarterly. Londres, v. 55, p. 205-217, 2006. p. 208-209.

${ }^{200}$ ZANETTI, Cristiano de Sousa. Responsabilidade pela Ruptura das Negociações. $1^{\text {a }}$ ed. São Paulo: Juarez de Oliveira, 2005. p. 115.
} 
perdas e danos evitáveis, já que o titular de um patrimônio tem o poder de dele se dispor. O segundo comportamento, contraditório, consistiria em exigir indenização por todos os prejuízos sofridos. Ambos os comportamentos são lícitos - disposição do patrimônio e exigência de indenização - e diferidos no tempo. Ocorre que, por serem condutas contraditórias, o credor estaria impedido de exigir indenização pelo agravamento de seu dano.

O equívoco neste raciocínio se encontra em diversos pontos. O primeiro deles consiste na razão da existência da proibição do venire contra factum proprium. A teoria dos atos próprios existe para a proteção da confiança entre as partes. Entretanto, inexiste a confiança que o credor não irá exigir indenização pelos danos sofridos, mormente que a lei não excluirá da apreciação do Poder Judiciário lesão ou ameaça a direito, conforme artigo $5^{\circ}$, inciso XXXV da Constituição Federal.

Com efeito, tratar a norma de mitigação como um ramo do venire contra factum proprium é tentar encaixar dois institutos com finalidades distintas nas mesmas situações. Enquanto o venire contra factum proprium protege a confiança, o duty to mitigate the loss delimita o direito subjetivo das partes e de sua cooperação ${ }^{201}$. A convergência na sua aplicação acarretaria no desvirtuamento de suas finalidades, tornando desnecessária a sua coexistência.

Também merece críticas a solução pela proibição do venire contra factum proprium acerca do seu próprio fundamento. Seja derivado diretamente do princípio da boa-fée ${ }^{202}$, seja do instituto do abuso de direito ${ }^{203}$ - que por sua vez é ramificação da boa-fé, conforme estabelecido no item anterior - é certo que a raiz da vedação ao comportamento contraditório acaba sendo a própria boa-fé. Assim, aplica-se a mesma crítica feita ao abuso de direito ${ }^{204}$ : não há razão para fundamentar o duty to mitigate the loss na proibição do venire contra factum proprium já que ambos estão estruturados no princípio da boa-fé.

\footnotetext{
${ }^{201}$ Vide a relação entre a mitigação e a cooperação no item 2.1.1.3.1.1. supra.

202 GAGLIANO, Pablo Stolze; PAMPLONA FILHO, Rodolfo. Novo Curso de Direito Civil 4 Tomo I Contratos: teoria geral. $8^{\mathrm{a}}$ ed. rev. atual. e ampl. São Paulo: Saraiva, 2012. p. 120.

${ }^{203}$ ZANETTI, Cristiano de Sousa. Responsabilidade pela Ruptura das Negociações. $1^{\text {a }}$ ed. São Paulo: Juarez de Oliveira, 2005. p. 114; CORDEIRO, Antonio Manuel da Rocha e Menezes. Da Boa Fé no Direito Civil. $4^{\mathrm{a}}$ reimpressão. Coimbra: Almedina, 2001. p. 742; TOMASEVICIUS FILHO, Eduardo. Informação assimétrica, custos de transação, princípio da boa-fé. São Paulo, 2007. Tese (Doutorado em Direito). Faculdade de Direito da Universidade de São Paulo; FARIAS, Cristiano Chaves de; ROSENVALD, Nelson. Direito Civil: teoria geral. Rio de Janeiro: Lumen Juris, 2009.

${ }^{204}$ Vide item anterior.
} 


\subsection{Confronto da mitigação com outros institutos}

\subsubsection{Mitigação e cláusula penal}

Como um pacto acessório, a cláusula penal é estipulada pelas partes para definir uma pena, normalmente pecuniária, de antemão contra aquela que culposamente deixou de cumprir sua obrigação, ainda que originária de uma cláusula especial, ou se está em mora, nos termos dos artigos 408 e 409 do Código Civil. Sua função, portanto, é ambivalente: reforça o vínculo obrigacional ao punir o inadimplemento e liquida antecipadamente as perdas e danos ${ }^{205}$.

Fixado um valor pecuniário na cláusula penal, estarão as perdas e danos pré-fixadas e, ocorrendo a inexecução nela prevista, a parte lesada terá direito de receber o valor fixado independentemente de qualquer alegação de prejuízo, conforme preleciona o caput do artigo 416 do Código Civil. E o parágrafo único do mesmo dispositivo aduz que as partes estarão vinculadas a este valor, mesmo que o prejuízo concretamente tenha excedido o que fora estipulado. A exceção fica por conta da previsão na própria cláusula de a parte poder exigir indenização suplementar, valendo então o montante estipulado como mínimo da indenização e o restante excedente sujeito a prova do credor.

Este parágrafo único é de especial interesse para o ônus do credor de mitigar seus danos. Afinal, em uma relação contratual, tendo sido convencionada uma cláusula penal, poder-se-ia aventar se caberia a discussão da redução do valor indenizatório pactuado na hipótese de incidir a norma de mitigação ao caso. Seria, por exemplo, a situação de ao ser aplicado o duty to mitigate the loss, o valor indenizatório ser inferior ao estipulado na cláusula penal.

Entendemos não ser possível. O próprio parágrafo único traz nitidamente a solução para a discussão quando vincula as partes ao valor pactuado. Ao estipularem a cláusula penal, as partes voluntariamente renunciam o poder de liquidar o dano posteriormente, realizando uma previsão daquilo que poderão despender no caso de haver uma inexecução ou mora. Adicionalmente, no âmbito da cláusula penal é descabida a discussão da existência de prejuízo ou não (caput do artigo 416 do Código Civil).

${ }^{205}$ DINIZ, Maria Helena. Manual de Direito Civil. $1^{\text {a }}$ ed. São Paulo: Saraiva, 2011. p. 153. 
As possibilidades de discussão para a redução equitativa do valor da cláusula penal se restringem às hipóteses do artigo 413 do Código Civil, quais sejam, se a obrigação principal tiver sido cumprida em parte ou se o montante da penalidade for manifestamente excessivo, tendo-se em vista a natureza e a finalidade do negócio. Só que isto se relaciona tão somente com o conteúdo do negócio celebrado, não cabendo, desse modo, indagações acerca de uma redução do quantum por conta do duty to mitigate the loss.

A única possibilidade de haver discussão do quantum é se houver disposição na cláusula penal acerca de uma das partes poder exigir indenização suplementar. Neste cenário, o credor, ao exigir que se pague além daquilo que fora convencionado, abrirá a possibilidade para o devedor questionar se o dano adicional não se deu por descumprimento pelo credor de seu ônus de mitigação. Assim como leciona o parágrafo único do artigo 416, o prejuízo dependerá de prova, abrindo possibilidade de incidência da norma de mitigação ainda que haja cláusula penal estipulada. O credor, então, só será indenizado pelas perdas e danos que efetivamente foram causadas pelo devedor e aquelas consideradas inevitáveis por exigir um esforço desarrazoado do credor, em inobservância do pressuposto de exigibilidade processual a ser desenvolvido adiante ${ }^{206}$.

\subsubsection{Mitigação e exceptio non adimpleti contractus}

Em um contrato bilateral, é vedado qualquer dos contratantes exigir a obrigação do outro enquanto não tenha cumprido a sua, nos termos do artigo 476 do Código Civil. Tratase de decorrência lógica da essência sinalagmática dos contratos bilaterais, haja vista que as obrigações contraídas pelas partes possuem uma dependência recíproca ${ }^{207}$. Por isso, a exceptio non adimpleti contractus serve como uma defesa oponível do contratante contra o inadimplente ${ }^{208}$, só podendo ser oposta “quando a lei ou o próprio contrato não determinar a quem cabe primeiro cumprir a obrigação ${ }^{209,}$.

O instituto se mostra interessante quando colocado sob análise em conjunto com o duty to mitigate the loss. Poder-se ia cogitar que, se houver inadimplência do devedor, o

\footnotetext{
${ }^{206}$ Vide Título II, Capítulo 3, item 3.3. supra.

${ }^{207}$ GOMES, Orlando. Contratos. 9a ed. Rio de Janeiro: Forense, 1983.p. 99.

${ }^{208}$ PEREIRA, Caio Mário da Silva. Instituições de Direito Civil - Vol. III. 12 ed. Rio de Janeiro: Forense, 2006. p. 159.

${ }^{209}$ GOMES, Orlando. Contratos. 9 ${ }^{\mathrm{a}}$ ed. Rio de Janeiro: Forense, 1983.p. 100.
} 
credor poderia invocar a exceptio non adimpleti contractus para não ter que cumprir a norma de mitigação.

Conforme visto nos itens 2.1.1.2.5.1., 2.1.1.2.5.1.1. e 2.1.1.2.5.2., a exceção de contrato não cumprido se aproxima bastante da exigível cooperação por conta do dever de facilitação do adimplemento a que as partes estão submetidas, com um temperamento pela teoria do adimplemento substancial. Ademais, o seu uso é evidência de uma crise de cooperação - a cooperação recusada, conforme leciona Betti ${ }^{210}$ - pois se admite a recusa de cooperação por existência de ato anterior que é contrário ao ordenamento jurídico.

Neste sentido, haveria uma contraposição interna entre dois institutos da boa-fé: um vinculado ao dever de cooperação e outro que constitui um ônus decorrente da função delimitadora de direitos subjetivos. Contudo, o conflito é apenas aparente. Os danos agravados pela inobservância da norma de mitigação do credor não são, desde a sua origem, imputáveis ao devedor. Não há minimização de culpa pela menor extensão do dano, mas sim, ausência de qualquer responsabilidade pela atuação gravosa do credor em descompasso com a diligência ditada pelo princípio da boa-fé. Dessa forma, a inadimplência do devedor autoriza apenas que o credor invoque a exceptio non adimpleti contractus para se abster de cumprir sua obrigação pactuada, e não para deixar de minimizar os prejuízos. Por isso, a exceptio non adimpleti contractus só poderá ser invocada se ela for propriamente uma medida de mitigação dos prejuízos, como maneira de não agravar ainda mais a situação do credor.

Vale lembrar o ensinamento de Couto e Silva, que não se pode deixar de cumprir o dever de cooperação pela exceptio non adimpleti contractus, pois isto se dá somente para a obrigação principal $^{211}$. Do mesmo modo, não é a norma de mitigação a obrigação principal e, por isso, não está submetida à exceção de contrato não cumprido.

\subsubsection{Mitigação e exercício tardio de um direito}

Com a necessidade de imediata tomada de medidas adequadas, poder-se-ia indagar se a mitigação estaria em conflito direto com o exercício tardio de um direito pelo credor.

\footnotetext{
${ }^{210}$ BETTI, Emilio. Teoria Generale delle Obbligazioni, v. 1, Prolegomeni, Funzione Economico-Sociale dei Rapporti d'Obbligazione. Milano: Giuffrè, 1953. p. 34.

${ }^{211}$ SILVA, Clóvis Couto e. A obrigação como processo. São Paulo: José Bushatsky, 1976. p. 117-118.
} 
Havendo a incidência da norma de mitigação, não caberia ao credor exercer seu direito em momento posterior, ainda que existisse prazo prescricional para o exercício da ação pertinente. Neste sentido, Tartuce leciona especificamente quanto aos contratos bancários:

Segundo a nossa interpretação, não pode a instituição financeira permanecer inerte, aguardando que, diante da alta taxa de juros prevista no instrumento contratual, a dívida atinja montantes astronômicos ${ }^{212}$.

Para ilustrar melhor a situação, é conveniente trazer jurisprudência do Tribunal de Justiça do Mato Grosso do $\mathrm{Sul}^{213}$.

O caso é o seguinte: foi celebrado em 17/12/1996 com a administradora de cartões de crédito Banestado um contrato de emissão e utilização dos cartões de crédito Banestado Visa que, conforme consta no acórdão, não teve as suas faturas pagas desde o dia 20/8/1999. O Banestado, ao invés de cobrar imediatamente o crédito, aguardou até 12/11/2004 para propor ação de cobrança contra o devedor, implicando na evolução do saldo devedor de $\mathrm{R} \$ 19.196,26$ para $\mathrm{R} \$$ 50.151,76. A Terceira Turma Cível então decidiu que o Banestado deveria ter cobrado a dívida logo que houvesse a inadimplência, impedindo que atingisse valores astronômicos. Considerou, assim, que se mostra razoável a redução do crédito do Banestado no período compreendido de 20/01/1997 a 20/08/1999, não merecendo reforma a sentença de $1^{a}$ instância. A decisão levou em consideração que o Banestado demorou a mitigar seus danos, piorando a situação do devedor por não cobrá-lo o quanto antes. Identificou, assim, que a postura do credor era violadora do princípio da boa-fé, não respeitando os preceitos inerentes ao duty to mitigate the loss.

A utilização da norma de mitigação como fundamento em casos como este evidenciam a confusão existente com o legítimo exercício tardio do direito, pois consideram a inércia do credor como motivo do prejuízo do credor e, com a posterior cobrança judicial, do devedor. Levada às últimas consequências, este entendimento impediria a cobrança da dívida após o decurso considerável de tempo, independentemente do decurso do prazo prescricional e da aplicação de juros e correção monetária. Afinal, não

\footnotetext{
${ }^{212}$ TARTUCE, Flávio. Direito Civil - Vol. 3 - Teoria Geral dos Contratos e Contratos em Espécie. $8^{\mathrm{a}}$ ed. São Paulo: Método, 2013. p. 112.

${ }^{213}$ BRASIL. Tribunal de Justiça do Estado do Mato Grosso do Sul, $3^{\text {a }}$ Turma Cível. Apelação Cível $n^{\circ}$ 2009.022658-4/0000-00. Apelante: Banestado Administradora de Cartões de Crédito Ltda. Apelado: Antonio Gentil Rodrigues. Rel. Des. Rubens Bergonzi Bossay, votação unânime, j. 21.09.2009.
} 
cobrar imediatamente é faltar com a boa-fé e negligenciar o duty to mitigate the loss. Com isso, não caberia qualquer direito à indenização.

As conclusões acabam levando a absurdos, mostrando que a incompatibilidade entre a norma de mitigação e o exercício tardio de um direito é apenas aparente, não sendo aplicável aos casos como o da jurisprudência mencionada acima. E a simples revisão do funcionamento do duty to mitigate the loss já torna isto claro.

Nas hipóteses como a acima há a transformação da norma de mitigação como um ônus de evitar o inadimplemento quando, na verdade, seu escopo é de evitar os prejuízos após a inadimplência. O devedor deixou de realizar o pagamento da dívida e, com isso, incrementou seu débito, inclusive com a incidência de juros e correção monetária. $\mathrm{O}$ agravamento do prejuízo - do devedor e não do credor - se deu pela sua própria falta de assiduidade no pagamento. O ônus de evitar o dano não é, portanto, do credor, mas sim do devedor. É nítido que “o débito aumenta porque o devedor não cumpre a sua obrigação e não porque o credor não exige o cumprimento ${ }^{214}$ ".

Não há falar, portanto, de aplicação do duty to mitigate the loss. O único que se encontra apto a reduzir o prejuízo é o próprio devedor que tem a obrigação de realizar o pagamento do débito. Não é a inércia do credor que agravou o prejuízo, mas a própria inadimplência do devedor. Dizer que o ajuizamento da ação de cobrança é a causa impeditiva do aumento do prejuízo é um equívoco, haja vista que, por si só, servirá para a cobrança por vias judiciais e para fazer com que o devedor pague coercitivamente. $\mathrm{O}$ credor só faz com que sejam estancados os danos a que está sujeito, mas sem qualquer controle em relação à mitigação ${ }^{215}$.

Por isso não há como concordar com Tartuce, referenciado alhures. O credor tem a seu favor os prazos prescricionais para poder exigir do devedor, dentro deste lapso, o cumprimento da obrigação. Períodos estes fixados por lei para que o credor saiba até qual limite pode exercer a sua pretensão e para que o devedor saiba até quando pode ser cobrado. A aplicação equivocada do duty to mitigate the loss acaba com a segurança trazida pela prescrição e, por conseguinte, fragiliza o vínculo obrigacional entre as partes: mesmo com o inadimplemento, o devedor pode se ver beneficiado pela exclusão do agravamento do débito como se não fosse de sua responsabilidade. Ademais, o credor nem

${ }^{214}$ DIAS, Daniel Pires Novais. O duty to mitigate the loss no Direito Civil brasileiro e o encargo de evitar o próprio dano. Revista de Direito Privado. Ano 12. n. 45. jan./mar. 2011. p. 133.

${ }^{215}$ LOPES, Christian Sahb Batista. A mitigação dos prejuízos no direito contratual. Belo Horizonte, 2011. Tese (Doutorado em Direito). Faculdade de Direito da Universidade Federal de Minas Gerais. p. 219. 
ao menos tem a obrigação de cobrar a dívida, pois tem a faculdade de perdoá-la se assim quiser, conforme o artigo 385 do Código Civil. Adicionalmente, se deixasse de cobrá-la, deixando o prazo prescricional transcorrer, seu comportamento não acarretaria em qualquer ilicitude, pois nem ao menos haveria agravamento do dano para o devedor. Por tais motivos, não há como admitir o duty to mitigate the loss em situações em que se cabe o legítimo exercício tardio de um direito.

\subsubsection{Mitigação e suppressio}

O exercício tardio de um direito também pode ser realizado de forma ilegítima. Neste caso, o titular o exerce mesmo não podendo, em razão de alguma vedação existente no ordenamento jurídico. É a hipótese, por exemplo, que o credor tenta cobrar dívida após o decurso do prazo prescricional. Se o devedor não quiser por livre e espontânea vontade adimplir $^{216}$, poderá contestar alegando a ocorrência da prescrição, não tendo o credor ação para exigir o seu direito.

Entretanto, existe um caso em que mesmo não havendo o decurso do lapso prescricional, o credor não poderá exigir o cumprimento da obrigação. Nestas situações se fala em suppressio (Verwirkung), pela qual ocorre a extinção do direito pelo seu não exercício por um período prolongado, já que, ao exercê-lo, o credor contrariaria a boa$\mathrm{fé}^{217}$. A sua incidência se dá nas situações em que existe uma consolidada confiança de que o titular não pretende exercer o direito ou aja como se não o tivesse, mas mesmo assim, ao contrário das expectativas geradas, o exerce, surpreendendo o devedor. O ponto central da suppressio consiste, portanto, na legítima confiança gerada pelo credor.

O objeto de proteção é o mesmo que o da vedação ao venire contra factum proprium, o que causa uma grande aproximação entre os institutos. Ambos os institutos protegem a confiança contra comportamentos contraditórios, sendo que a suppressio atribui maior ênfase ao tempo ${ }^{218}$. Na vedação ao venire contra factum proprium há um primeiro comportamento lícito seguido de um segundo, ilícito, com a intenção de desfazer o primeiro. Na suppressio também há a sucessão de comportamentos lícitos e ilícitos

\footnotetext{
${ }^{216}$ Conforme autoriza o artigo 191 do Código Civil, entendendo ser o caso de renúncia à prescrição consumada.

217 CORDEIRO, Antonio Manuel da Rocha e Menezes. Da Boa Fé no Direito Civil. $4^{\mathrm{a}}$ reimpressão. Coimbra: Almedina, 2001. p. 797.

${ }^{218}$ Idem, ibidem. p. 813.
} 
respectivamente, mas a inatividade entre os comportamentos é que torna ilícito o segundo. Por serem diferenças tão pequenas, há quem defenda ser a suppressio derivação da própria proibição do venire contra factum proprium, sendo simplesmente uma regulamentação mais específica e precisa dada a extensão do conteúdo desta.

A aproximação com a vedação ao comportamento contraditório acaba por atrair a mesma crítica feita no item 2.2.1 quando se discutia a possibilidade de ser fundamento do duty to mitigate the loss. Enquanto a suppressio protege a confiança, o duty to mitigate the loss delimita o direito subjetivo das partes e de sua cooperação.

Assim, resgatando o caso do item 2.3.3 supra, se a administradora de cartão de crédito tivesse agido de maneira a inspirar confiança ao devedor de que não cobraria as parcelas inadimplidas do período em que se manteve inerte, poderia haver a incidência da suppressio, mas não da norma de mitigação. A questão aqui é focada na confiança depositada de que não haveria um comportamento contraditório após considerável lapso temporal.

Por isso, não se encaixa o argumento de que o credor tinha o ônus de mitigar ou evitar seu prejuízo. O prejuízo advém unicamente do inadimplemento, não são danos outros posteriores evitáveis. A extinção da pretensão se deu pelo decurso do tempo em que houve confiança legítima de que não seria o direito exercido, e não pela falta de tomada de medida adequada pelo credor. Dessa maneira, assim como a norma de mitigação não se confunde com a teoria dos atos próprios, também não se confunde com a suppressio.

\subsubsection{Mitigação e inversão do ônus da prova}

A proteção ao consumidor no ordenamento jurídico pátrio é regida por princípios específicos, entre eles a vulnerabilidade, a qual considera o consumidor a parte fraca da relação jurídica de consumo. Decorre esta presunção da sua fragilidade técnica e econômica frente o conhecimento monopolizado do fornecedor dos meios de produção ${ }^{219}$. Como desdobramento desta especial proteção, o artigo $6^{\circ}$, inciso VIII do Código de Defesa do Consumidor prevê a possibilidade de inversão do ônus da prova em favor do

\footnotetext{
${ }^{219}$ NUNES, Luiz Antonio Rizzatto. Curso de direito do consumidor. $4^{\text {a }}$ ed. São Paulo: Saraiva, 2009. p. 129130.
} 
consumidor em situações em que esteja em evidência a sua hipossuficiência na produção de provas em seu favor no processo judicial ou quando verossímeis suas alegações.

A hipossuficiência tratada no dispositivo legal é a técnica, e não econômica. O consumidor não deve ter a possibilidade de chegar ao conhecimento técnico e informativo sobre o produto ou serviço, algo que só está no alcance do fornecedor. Assim, cabe a este a produção da prova quando assim o juiz determinar, pois é a parte com maiores facilidades para a obtenção de dados relativos à questão. A verossimilhança, por sua vez, é caracterizada pela proximidade do que é descrito na peça processual com a realidade. Havendo esta aparência de que o que está descrito ser expressão da verdade real ${ }^{220}$, poderá o magistrado decretar a inversão do ônus da prova.

A grande celeuma não definida pelo Código de Defesa do Consumidor, no entanto, consiste no momento em que o magistrado está autorizado a inverter o ônus da prova. Ainda que exista pensamento em sentido diverso entendendo ser no momento da prolação da sentença, a maioria entende que o momento processual adequado é entre o pedido inicial e o despacho saneador, inclusive $\mathrm{e}^{221}$. Se a inversão do ônus da prova é um critério a ser aplicado pelo juiz, então este precisa se manifestar previamente à sentença no processo acerca do reconhecimento da hipossuficiência do consumidor ou da verossimilhança de suas alegações.

Esta definição se mostra de suma importância para o duty to mitigate the loss, haja vista que, havendo relação de consumo, é preciso que o devedor saiba se incumbe a ele provar que o credor não observou a norma de mitigação ou não. Neste diapasão, é preciso destacar as duas possíveis situações: quando o credor é o fornecedor e o devedor o consumidor e quando o credor é o consumidor e o devedor o fornecedor.

No caso de o credor ser o fornecedor e o devedor o consumidor, este último é o réu da ação judicial de indenização por perdas e danos. Logo, havendo inversão do ônus da prova, o devedor-consumidor não precisará provar que o dano era evitável, pois isto será um ônus do credor-fornecedor que propôs a ação. Assim, o credor-fornecedor terá duas opções: poderá desde logo na petição inicial provar a inevitabilidade do dano ou após a decisão em que é realizada a inversão, colacionar as provas da inevitabilidade.

\footnotetext{
${ }^{220}$ GRINOVER, Ada Pellegrini et al. Código Brasileiro de Defesa do Consumidor comentado pelos autores do Anteprojeto. 9. ed. Rio de Janeiro: Forense Universitária, 2007. p. 153.

${ }^{221}$ NUNES, Luiz Antonio Rizzatto. Curso de direito do consumidor. $4^{\mathrm{a}}$ ed. São Paulo: Saraiva, 2009. p. 784785 .
} 
Na situação inversa, ou seja, sendo devedor o fornecedor e credor o consumidor, com a inversão do ônus da prova, o credor-consumidor não precisará produzir provas se o dano era evitável. Sobra para o devedor-fornecedor fazer prova da inevitabilidade na própria contestação, se já determinada a inversão do ônus probatório na decisão judicial que determinou a citação ou após qualquer outra decisão que a determine.

\subsubsection{Mitigação e contrato de seguro}

É possível reconhecer um traço de adoção da norma de mitigação no direito brasileiro quando se analisa os dispositivos relacionados ao contrato de seguro presentes no Código Civil. Por isso, além do artigo 77 da Convenção das Nações Unidas sobre Contratos de Compra e Venda Internacional de Mercadorias (CISG) ${ }^{222}$, que trata especificamente do comércio internacional, o ordenamento jurídico pátrio também o fez expressamente nos artigos 769 e 771 do Código Civil. Ambos são normas jurídicas de aplicação em campos específicos: o dispositivo da CISG nos contratos de compra e venda internacional e os artigos do Código Civil nos contratos de seguro, não existindo no ordenamento jurídico, portanto, lei que trate do duty to mitigate the loss genericamente.

O artigo 769 dispõe que o segurado é obrigado a comunicar ao segurador, logo que saiba, todo incidente suscetível de agravar consideravelmente o risco coberto, sob pena de perder o direito à garantia, se provar que silenciou de má-fé. O artigo 771, por sua vez, determina que o segurado comunicará o sinistro ao segurador desde logo e tomará as providências imediatas para minorar-lhe as consequências, sob pena de perder o direito à indenização.

Os dispositivos brasileiros recordam o sistema alemão de seguros, o qual originou a ideia da Obliegenheit. Assim como foi explicado alhures ${ }^{223}$, nele o segurado tinha a obrigação de avisar, logo, o sinistro e deveria - uma incumbência, menor que um dever propriamente dito - mitigar seus danos. Antes de vigorar este sistema, caso houvesse o descumprimento desta obrigação, a seguradora não tinha meios para acionar o Judiciário,

\footnotetext{
${ }^{222}$ Para mais informações sobre este dispositivo, ver o Título III, Capítulo 6, item 6.3., infra.

${ }^{223}$ Vide Título I, Capítulo 3, item 3.2. infra.
} 
já que o duty to mitigate the loss é inexigível. Dessa maneira, o caminho mais simples era não conceder indenização nos casos de descumprimento da norma de mitigação ${ }^{224}$.

A fórmula trazida pelos artigos 769 e 771 do Código Civil não é diferente. Pela leitura conjugada de ambos os preceitos, é evidente existir um ônus do segurado de mitigar o próprio prejuízo para que não piore a sua situação, o que levaria posteriormente à seguradora a arcar com danos maiores do que aqueles que efetivamente fugiram do campo da evitabilidade do segurado. Em outras palavras, se os prejuízos eram evitáveis pelo segurado, o próprio diploma legal civil estabelece uma sanção típica do duty to mitigate the loss: a perda do direito de indenização e da garantia se provada a má-fé.

\subsubsection{Mitigação e gestão de negócios}

A gestão de negócios é caracterizada pela intervenção de gestão em negócio alheio sem autorização do dono, dirigindo-o segundo o que se presume ser a sua vontade. $\mathrm{O}$ Código Civil tratou desse assunto nos artigos 861 a 875, disciplinando diversas possíveis situações que as partes envolvidas numa relação desta espécie poderiam se deparar. Diniz $^{225}$ exemplifica o instituto com a situação em que um vizinho vê arrebentados os encanamentos da casa contígua, correndo o risco de ficar inundada. Com a ausência do proprietário, o vizinho poderá efetuar gastos indispensáveis para o conserto do encanamento, impedindo o dano iminente.

O instituto da gestão de negócios parece se aproximar bastante dos mandamentos do duty to mitigate the loss, tendo em vista que em ambos há a mitigação de um prejuízo evitável, com a utilização de esforços que não se tornem perigosos ou onerosos sem que haja convenção ou obrigação legal prévia que obrigue a outra parte a agir dessa maneira. Estariam presentes, então, as características da evitabilidade e inexigibilidade, próprias da norma de mitigação, e o pressuposto de existência da possibilidade de atuação razoável do gestor.

No entanto, estão ausentes os demais pressupostos de existência: do inadimplemento e do dano imputável ao dono do negócio. Ambos pelo mesmo motivo: o

\footnotetext{
${ }^{224}$ CORDEIRO, António Manuel da Rocha e Menezes. Tratado de direito civil português: introdução, doutrina geral, negócio jurídico. v. 1, t. 1., Coimbra: Almedina. p. 359.

${ }^{225}$ DINIZ, Maria Helena. Manual de Direito Civil. $1^{\mathrm{a}}$ ed. São Paulo: Saraiva, 2011. p. 280.
} 
prejuízo se insere na esfera jurídica do dono do negócio, e não do gestor. Não há mitigação de dano próprio, mas de outrem, já que o gestor somente se responsabiliza pelas relações jurídicas do dono do negócio, não envolvendo direito do qual é titular.

A confusão entre ambos os institutos também poderia estar refletida na redação do artigo 870 do Código $\mathrm{Civil}^{226}$, já que prevê um reembolso ao gestor em valor que não ultrapassa as vantagens obtidas com a gestão. Contudo, trata-se de indenização por despesas havidas na mitigação de prejuízos iminentes no patrimônio do dono do negócio, sendo uma forma de não prejudicar o gestor pelos gastos que teve que arcar por conta do prejuízo alheio. O gestor cumpre um "mandato" e, por isso, sua esfera patrimonial não pode ser afetada por despesas do dono do negócio; assim havendo, é crucial que haja compensação.

Voltando ao exemplo de Diniz ${ }^{227}$, cogitar-se-ia se haveria incidência do duty to mitigate the loss na gestão de negócios se o problema no encanamento atingisse também a residência do vizinho. Neste caso, o gestor estaria mitigando o próprio dano, isto é, estaria atendendo não só aos interesses do dono do negócio, mas também aos seus. A situação é bastante peculiar, já que se misturam interesses - enquanto que na regra geral da gestão de negócios isso não ocorre -, mas não dificultam a resolução.

Como foi estabelecida uma relação jurídica diversa entre gestor e dono do negócio, haverá incidência do duty to mitigate the loss. Só que esta relação não se forma por conta da gestão de negócios, e sim, como naturalmente existiria entre indivíduos que se encontram na situação de vizinhos. Estão neste escopo preenchidos todos os pressupostos de existência, pois houve o inadimplemento (o dano causado pelo problema no encanamento), o dano é imputável ao dono do negócio (pois dono da casa e do encanamento defeituoso) e há a possibilidade razoável de o gestor mitigar este dano. A aplicação e consequências dela próprias do duty to mitigate the loss ocorrerão da maneira usual, consoante está sendo estudado e desenvolvido neste estudo. A situação de serem partes envolvidas numa gestão de negócios em nada influi na norma de mitigação.

\footnotetext{
${ }^{226}$ Art. 870. Aplica-se a disposição do artigo antecedente, quando a gestão se proponha a acudir a prejuízos iminentes, ou redunde em proveito do dono do negócio ou da coisa; mas a indenização ao gestor não excederá, em importância, as vantagens obtidas com a gestão.

${ }^{227}$ DINIZ, Maria Helena. Manual de Direito Civil. $1^{\mathrm{a}}$ ed. São Paulo: Saraiva, 2011. p. 280.
} 


\subsubsection{Mitigação e dano moral}

O dano moral, também referido como dano extrapatrimonial, pode ser entendido como todo dano que repercuta na esfera extrapatrimonial da vítima. São aqueles danos que trazem ao ofendido sofrimento psíquico, excluindo-se todas as perdas simplesmente pecuniárias, atinentes ao seu patrimônio. Dano moral

é aquele que, independentemente de prejuízo material, fere direitos personalíssimos, isto é, todo e qualquer atributo que individualiza cada pessoa, tal como a liberdade, a honra, a atividade profissional, a reputação, as manifestações culturais e intelectuais, entre outros. O dano é ainda considerado moral quando os efeitos da ação, embora não repercutam na órbita de seu patrimônio material, originam angústia, dor, sofrimento, tristeza ou humilhação à vítima, trazendo-lhe sensações e emoções negativas ${ }^{228}$.

No tocante a sua da reparação, a inexistência de critérios legais específicos para a sua fixação transferiu o ônus da criação de parâmetros para a doutrina e a jurisprudência, o que tornou a questão objeto de intensos debates ${ }^{229}$. São apontadas três formas possíveis de

${ }^{228}$ MORAES, Maria Celina Bodin de. Danos à pessoa humana: uma leitura civil-constitucional dos danos morais. Rio de Janeiro: Renovar, 2003. p. 157.

${ }^{229}$ Diniz, por exemplo, traça alguns parâmetros objetivos que acredita que o magistrado deva levar em conta na fixação do quantum indenizatório:

“a) evitar indenização simbólica e enriquecimento sem justa causa, ilícito ou injusto da vítima. A indenização não poderá ter valor superior ao dano, nem deverá subordinar-se à situação de penúria do lesado; nem poderá conceder a uma vítima rica uma indenização inferior ao prejuízo sofrido, alegando que sua fortuna permitiria suportar o excedente do menoscabo;

b) não aceitar tarifação, porque esta requer despersonalização e desumanização, e evitar porcentagem do dano patrimonial;

c) diferenciar o montante indenizatório segundo a gravidade, a extensão e a natureza da lesão;

d) verificar a repercussão pública provocada pelo fato lesivo e as circunstâncias fáticas;

e) atentar para as peculiaridades do caso e para o caráter antisocial da conduta lesiva;

f) averiguar não só os benefícios obtidos pelo lesante com o ilícito, mas também a sua atitude ulterior e situação econômica;

g) apurar o real valor do prejuízo sofrido pela vítima;

h) levar em conta o contexto econômico do País; no Brasil não haverá lugar para fixação de indenizações de grande porte, como as vistas nos Estados Unidos;

i) verificar a intensidade do dolo ou o grau de culpa do lesante;

j) basear-se em prova firme e convincente do dano;

k) analisar a pessoa do lesado, considerando a intensidade de seu sofrimento, seus princípios religiosos, sua posição social ou política, sua condição profissional e seu grau de educação e cultura;

1) procurar a harmonização das reparações em casos semelhantes;

m) aplicar o critério do justum ante as circunstâncias particulares do caso sub judice (LICC, art. $5^{\circ}$ ), buscando sempre, com cautela a prudência objetiva, a equidade". (DINIZ, Maria Helena. O Problema da Liquidação do Dano Moral e o dos Critérios para a Fixação do Quantum Indenizatório. Atualidades Jurídicas, v. 2, p. 237-

272. São Paulo: Saraiva, 2000. p. 266-267) 
reparação ${ }^{230}$ : a reparação in natura, os modelos especiais de reparação e a compensação pecuniária. Das três, a terceira forma é a mais comum.

A reparação in natura é, como regra, impossível, pois não há como retornar o ofendido ao seu status quo ante da mesma maneira que acontece em um dano patrimonial. No entanto, existem certas situações que a medida adotada como resposta para o dano moral se aproxima materialmente de uma reparação in natura e, por razões acadêmicas, é assim definida. Medeiros Neto aponta alguns exemplos:

(I) a retratação pública, nos casos de discriminação social, cultural ou étnica;

(II) a republicação de material (artigo, foto desenho, texto etc.), dessa feita com a indicação do nome do autor da obra (Lei n. 5988/73, art. 126);

(III) a contrapropaganda, em casos de publicidade enganosa ou abusiva;

(IV) a publicação gratuita de sentença condenatória às custas do infrator e a divulgação de reclamações fundamentadas contra fornecedores de produtos ou de serviços (Lei n. 8.078/90, arts. 60, 78 e 44) ${ }^{231}$.

Os modelos especiais de reparação (ou reparação in natura impura) revelam-se interessantes quando o autor do dano moral não possui patrimônio suficiente para a reparação e/ou a reparação in natura se mostra insuficiente ou incabível ${ }^{232}$. Admite-se então a imposição de obrigações de fazer ou de não fazer, condizentes com o caso em apreço $^{233}$.

Por fim, o modelo de reparação por compensação pecuniária é a via mais comum, pelo qual se atribui um montante em dinheiro que seria o equivalente ao dano moral sofrido. O juiz, em seu prudente arbítrio, levando em consideração as circunstâncias do caso e à luz do princípio da reparação integral, determinará montante indenizatório que mais se aproxime de uma recomposição pelos sentimentos negativos causados pelo autor

\footnotetext{
${ }^{230}$ MEDEIROS NETO, Xisto Tiago de. Dano moral coletivo. 2. ed. São Paulo: LTr, 2007. p. 76-77.

${ }^{231}$ Idem, ibidem. p. 77-78.

${ }^{232}$ BITTAR, Carlos Alberto. Reparação civil por danos morais. $3^{\mathrm{a}}$ ed. rev. atual. e amp. São Paulo: Revista dos Tribunais, 1999. p. 229-230.

233 "Esta reparação in natura impura poderia ser observada na indesejada situação em que uma empresa de casacos de pele erradicasse uma hipotética espécie animal. Responsabilizada por tal ato, a empresa lesante seria condenada a doar 100.000 casacos a uma instituição de caridade ou à "adoção" de outra espécie em extinção. Recomendável esta hipótese? Você decide, uma vez que é juridicamente possível”. (SEVERO, Sérgio. Os danos extrapatrimoniais. São Paulo: Saraiva, 1996. p. 194)
} 
do dano moral. Arbitrará valor que, consoante o ordenamento jurídico brasileiro, seja suficiente para neutralizar os efeitos negativos do dano moral ${ }^{234}$.

Uma dificuldade que se apresenta é a necessidade de o ofendido observar o duty to mitigate the loss também quando se está diante de um dano moral. E é também um problema tormentoso nos países de common law. Conforme apontam Klein e Hininger, as Cortes estadunidenses são vacilantes no reconhecimento da norma de mitigação no dano moral, ora a aplicando com total recuperação do valor, ora a aplicando com recuperação parcial, e outras simplesmente negando a sua aplicação ${ }^{235}$. E as decisões que aplicam o duty to mitigate the loss ao dano moral são recentes, sendo a primeira vez reconhecida sua incidência na Suprema Corte do Missouri em $1983^{236}$.

No reconhecimento da incidência do ônus da mitigação, ficou fixado que três elementos devem estar presentes: a conduta negligente do autor, a previsibilidade pelo autor que aquela conduta causaria um dano de natureza extrapatrimonial e a efetiva ocorrência do dano moral ${ }^{237}$. No tocante ao dano moral em si, para ser considerado relevante a ponto de merecer reparação, restou definido que deve o autor do dano compreender que sua conduta envolveu um risco não razoável de causar o prejuízo e que o dano moral deve ser possível de ser diagnosticado pela medicina ${ }^{238}$.

A mitigação incidiria sobre aquele prejudicado que, sabendo ser necessário se submeter a uma farmacoterapia ou psicoterapia, assim não procede. Permitiu de maneira reprovável que seu abalo psíquico se mantivesse ou agravasse e, só depois de muito sofrer e se afundar em seus tormentos mentais é que vem pleitear indenização de alto valor.

\footnotetext{
${ }^{234}$ É cediço, contudo, a dificuldade de se estabelecer um valor que seja equivalente à extensão do dano moral. Tanto que é usual a reforma pelos tribunais de sentenças que exacerbam ou restringem demasiadamente o valor que é considerado razoável como compensação.

${ }^{235}$ KLEIN, Kevin C.; HININGER, Nicole G. Mitigation of Psychological Damages: An Economic Analysis of the Avoidable Consequences Doctrine and Its Applicability to Emotional Distress Injuries. Oklahoma City University Law Review, v. 29, p. 405-439, 2004. p. 406.

${ }^{236}$ Bass v. Nooney Co., 646 S.W.2d 765, $772-73$ (Mo. 1983), visto em KLEIN, Kevin C.; HININGER, Nicole G. Mitigation of Psychological Damages: An Economic Analysis of the Avoidable Consequences Doctrine and Its Applicability to Emotional Distress Injuries. Oklahoma City University Law Review, v. 29, p. 405439, 2004. p. 412.

${ }^{237}$ Mullis v. Mechanics \& Farmers Bank, 994 F. Supp. 680, 688 (M.D.N.C. 1997), visto em KLEIN, Kevin C.; HININGER, Nicole G. Mitigation of Psychological Damages: An Economic Analysis of the Avoidable Consequences Doctrine and Its Applicability to Emotional Distress Injuries. Oklahoma City University Law Review, v. 29, p. 405-439, 2004. p. 413.

${ }^{238}$ Bass v. Nooney Co., 646 S.W.2d 765, $772-73$ (Mo. 1983), visto em KLEIN, Kevin C.; HININGER, Nicole G. Mitigation of Psychological Damages: An Economic Analysis of the Avoidable Consequences Doctrine and Its Applicability to Emotional Distress Injuries. Oklahoma City University Law Review, v. 29, p. 405439, 2004. p. 413. Acrescente-se, aqui, que a moléstia também deve poder ser diagnosticada por um psicólogo (Idem, ibidem. p. 414-415).
} 
O que parece, na opinião de Klein e Hininger, é existir ainda uma grande contradição interna na common law das Cortes ao confiar na opinião médica quando o dano é físico, mas não quando é moral. Além disso, parece ser mais aceitável aumentar o valor da indenização e não diminuí-1o ${ }^{239}$. Também lhes parece ser um motivo a autonomia do dano moral, desacompanhado de um pleito sem dano físico, ser ainda uma novidade na common law. E finalmente, consideram que a defesa nos processos parece achar ofensivo o argumento de mitigação sobre um dano que seu próprio cliente causou ${ }^{240}$.

Parece seguro dizer que o ordenamento jurídico pátrio também admite a mitigação no caso do dano moral. Ainda que se trate de um dano psíquico, é certo que o ofendido pode deixar de procurar a ajuda profissional necessária, agravando ainda mais a sua condição já precária de saúde mental. Neste sentido, cobrar por uma alta indenização é atentar contra o princípio da boa-fé: o ofendido se aproveita da responsabilidade do ofensor para lucrar o máximo possível, e não porque simplesmente o montante serviria como uma reparação ao abalo sofrido.

A busca por ajuda profissional é uma medida razoável, que afasta o perigo do agravamento do dano moral. A contrario sensu, não realizar uma farmacoterapia ou psicoterapia é uma medida perigosa, que atenta contra a vida do ofendido. Sendo perigosa, não supera a segunda etapa da regra de aferição da razoabilidade.

Claro que tais medidas, quais seja, de se submeter a tratamentos, só são exigíveis se assim houver recomendação profissional. Exigir para todos os casos que envolvem dano moral um tratamento de saúde é, no mínimo, desproporcional. Um abalo psíquico em razão de mau funcionamento de um serviço de telefonia celular, a princípio, não causaria um dano o bastante a ensejar tratamento psicológico, por exemplo. Por isso, para a incidência da norma de mitigação, é preciso que o ofendido tenha sido recomendado a se submeter à farmacoterapia ou psicoterapia.

A submissão ao tratamento é, em regra, uma medida adequada, não perigosa e não onerosa. Só é cabível uma observação em relação à onerosidade, que só seria onerosa a medida se o ofendido não dispusesse de recursos financeiros suficientes; seja por falta de dinheiro, seja pelo elevado valor do tratamento ${ }^{241}$. O ofendido então, em uma futura ação

\footnotetext{
${ }^{239}$ Idem, ibidem. p. 426.

${ }^{240}$ Idem, ibidem. p. 424-425.

${ }^{241}$ Claro que há a possibilidade de impetração de um mandado de segurança para o custeio do tratamento pelo Poder Público. Todavia, é preciso verificar se as circunstâncias específicas do caso permitem o manejo desta medida.
} 
de indenização, pleitearia o ressarcimento da quantia gasta com o tratamento para mitigar o seu dano moral.

Na segunda etapa da regra de aferição da razoabilidade, a ser estudada no Capítulo seguinte, o magistrado apreciará se houve por parte do ofendido a mitigação do dano moral. Apreciará se o ofendido tomou as medidas razoáveis para o caso - isto é, se o ofendido se submeteu ao tratamento farmacoterápico ou psicoterápico recomendado - $\mathrm{e}$ definirá o quantum indenizatório, se houver. Em caso de dúvida da eficiência da medida, o magistrado poderá se valer de um perito, o qual poderá atestar se o tratamento recomendado possuía o condão de minimizar, evitar ou eliminar os efeitos do dano moral.

Por fim, cabe analisar se ao invés de o ofendido pleitear indenização por compensação pecuniária, pedir reparação in natura ou por um modelo especial de reparação. A questão acaba recaindo no mesmo problema já analisado no item 4.3., já que as perdas e danos constituem um pressuposto de exigibilidade processual. Assim, se não houver pedido de compensação pecuniária, isto é, se não envolver valores monetários, não há como o ofensor alegar inobservância da norma de mitigação.

\subsection{A impropriedade do termo duty}

Pode-se traduzir duty to mitigate the loss, literalmente, para o "dever de mitigar o prejuízo". Ainda que a expressão já esteja popularizada e consagrada em inúmeros estudos, como se viu anteriormente não é adequado compreender a norma de mitigação como um dever jurídico.

Embora existam aqueles que entendam como adequado o dever como natureza jurídica da mitigação, não faltam críticas na common law a esta concepção. Há aqueles que entendem que, em um sentido filosófico, a mitigação como um dever faz sentido, já que é uma obrigação daquele que agiu desde o início de maneira correta que continue mesmo diante da inadimplência; tratar-se-ia de uma obrigação observada no campo da moralidade ${ }^{242}$. Outra corrente, minoritária, por sua vez, nega a própria existência do duty to mitigate the loss, em razão da dúvida que paira acerca da existência autônoma da doutrina

\footnotetext{
${ }^{242}$ LITVINOFF, Saúl. Damages, Mitigation, and Good Faith. Tulane Law Review, New Orleans, v. 73, p. 1161-1195, 1999. p. 1170.
} 
das consequências evitáveis ${ }^{243}$. Por fim, há aqueles que consideram a existência de autonomia da norma de mitigação, mas vinculada a natureza jurídica diversa.

A polêmica acaba sendo, por vezes, refletida na legislação, a qual tenta evitar designar diretamente uma natureza jurídica para os dispositivos que tratam da doctrine of avoidable consequences. O $§ 350$ do Restatement (Second) of Contracts $^{244}$ não se utiliza do termo "dever" ao tratar da norma de mitigação, mas especifica os limites que a indenização, na inobservância da regra das consequências evitáveis, precisa seguir:

\section{§ 350. Evitabilidade como limitação das perdas e danos}

(1) Exceto conforme estabelecido na Subseção (2), as perdas e danos não são indenizáveis pela perda que a parte prejudicada poderia ter evitado sem indevido risco, ônus ou desonra.

(2) A parte prejudicada não está impedida de ser indenizada pela regra referida na Subseção (1) na medida em que fez esforços razoáveis mas sem sucesso para evitar a perda ${ }^{245}$.

Mesmo assim, como dito alhures, a expressão duty to mitigate the loss já ultrapassou seu significado técnico, ganhando relevância como meio de identificação do instituto. Por isso, muitos daqueles que defendem não se tratar de um dever, ainda utilizam o termo $d u t y^{246}$, embora pareça existir maior preferência pela utilização da expressão “princípio da mitigação" (mitigation principle) ${ }^{247}$.

O artigo 2002 do Código Civil da Louisiana ${ }^{248}$ adotou postura diversa do Restatement (Second) of Contracts. Traz em sua redação a noção de dever de mitigação na sua primeira parte, mas encerra o raciocínio na segunda parte com a noção de limitação:

\footnotetext{
${ }^{243}$ Sobre a discussão acerca do duty to mitigate the loss ser uma doutrina autônoma na common law, vide Título I, Capítulo 1, item 1.2.1. supra.

${ }^{244}$ Trata-se de compilação realizada pelo American Law Institute da jurisprudência estadunidense para facilitar o estudo e aplicação dos entendimentos e precedentes. Contém dispositivos que resumem precedentes sobre determinado assunto, comentários dos relatores do Restatement (Second) of Contracts e exemplos de casos em que se aplicam o dispositivo.

245 Tradução livre do original.

${ }^{246}$ SAIDOV, Djakhongir. Methods of Limiting Damages under the Vienna Convention on Contracts for the International Sale of Goods. Dezembro de 2001. Disponível em: http://cisgw3.law.pace.edu/cisg/biblio/saidov.html. Acesso em 07/02/2014.

${ }^{247}$ GOETZ, Charles J.; SCOTT, Robert E. The mitigation principle: toward a general theory of contractual obligation. Virginia Law Review. v. 69, p. 967-1024, setembro de 1983.

${ }^{248} \mathrm{O}$ estado da Louisiana é um caso peculiar nos Estados Unidos, tendo em vista que é o único que adota o sistema da civil law. Mesmo assim, como se trata de um estado estadunidense, compartilhando assim noções jurídicas presentes nos demais estados que adotam a common law, preferimos tratar esta hipótese neste item.
} 
Artigo 2002. Esforços razoáveis para mitigar os prejuízos

Um credor deve realizar esforços razoáveis para mitigar os prejuízos causados pela falha do devedor de prestar. Quando um credor falha em realizar tais esforços, o devedor poderá demandar que os prejuízos sejam conformemente reduzidos ${ }^{249}$.

A redação bastante se assemelha àquela do artigo 77 da $\mathrm{CISG}^{250}$. O sistema da common law não se preocupa em perquirir a culpa, traduzida na negligência do credor de mitigar seu prejuízo. A relação de causalidade e a limitação da indenização são levadas muito mais em conta, tornando a presença da expressão "dever" muito mais como ênfase para a observância da regra das consequências evitáveis do que pela sua natureza jurídica $^{251}$.

O Código da Virgínia não trouxe solução diversa. O §8.01-66 e o §51.5-46 trazem a expressão duty to mitigate damages, mas em hipóteses específicas ao invés de uma regra geral. No primeiro dispositivo, o dever de mitigação é aplicado diretamente no caso de danos ou destruição de veículo automotor, podendo o proprietário cobrar não só as despesas do conserto, como também o custo razoável do aluguel de um veículo substituto pelo período em que o veículo danificado estava no conserto. A locação, contudo, não pode ultrapassar o período razoável que levaria para consertar o veículo danificado, sob pena de não ser ressarcido do valor do aluguel por força do dever de mitigação.

No segundo dispositivo, o dever de mitigação é aplicado ao direito de ação de pessoas portadoras de necessidades especiais. Estabelece que caso a pessoa sofra alguma violação nos direitos presentes no capítulo 9 do título 51.5, terá um ano para propor ação, contado da data de sua ocorrência. Só que tal direito estará extinto se não houver nenhuma notificação dentro de 180 dias ao provável autor do dano contados do fato violador. Além disso, o vencimento das obrigações não ocorrerá dentro de 180 dias antes da notificação e a responsabilidade ficará limitada a 180 dias, descontados os rendimentos deste período. Neste lapso temporal, deverá haver a mitigação dos prejuízos.

Dentre aqueles que se dedicam ao estudo da common law, parece haver maioria a favor do entendimento de ser a doutrina das consequências evitáveis uma doutrina

\footnotetext{
${ }^{249}$ Tradução livre do original.

${ }^{250}$ Vide Título III, Capítulo 6, item 6.3.

${ }^{251}$ HONNOLD, John O. Uniform Law for International Sales under the 1980 United Nations Convention. $3^{\mathrm{a}}$ ed. 1999. p. 456. Disponível em http://www.cisg.law.pace.edu/cisg/biblio/honnold.html. Acesso em 07/02/2014; LITVINOFF, Saúl. Damages, Mitigation, and Good Faith. Tulane Law Review, New Orleans, v. 73, p. 1161-1195, 1999. p. 1164; FORTIN, Lisa A. Why There Should Be a Duty to Mitigate Liquidated Damages Clauses. Hofstra Law Review. v. 38, p. 285-318, 2009-2010. p. 287.
} 
autônoma, estruturada sobre natureza jurídica peculiar, diversa de um dever. Defendem não existir uma norma específica que reconheça um direito de ação contra a inobservância do duty to mitigate the loss, mas impede que aquele que o desrespeitou seja indenizado pelos danos não mitigados ${ }^{252}$. Pela sua autonomia conceitual, a mitigação não se origina de um dever jurídico, sendo utilizada referida expressão como mero reforço retórico.

Assim, na mesma esteira daquilo que já fora estudado no item 2.1.1.3.1., a natureza jurídica da norma de mitigação é mais bem preenchida com o instituto do ônus, por não se tratar de desdobramento do princípio da boa-fé dotado de exigibilidade pela parte contrária, e sim, como uma incumbência em benefício de si mesmo que, caso seja desrespeitada, acarretará em consequências jurídicas ao próprio violador. O dever jurídico, em consonância do que fora desenvolvido no item 2.1.1.2.6., é natureza jurídica adequada para os demais deveres jurídicos anexos oriundos do princípio da boa-fé, haja vista que deles o devedor poderá exigir do credor seu cumprimento; até porque a inobservância acarreta um prejuízo para o patrimônio - material ou moral - do devedor. Já no caso da norma de mitigação, seu desrespeito pelo credor acarreta em prejuízo ao seu próprio patrimônio.

Portanto, reputa-se incorreta a utilização da expressão duty to mitigate the loss, a qual transmite a equívoca ideia de a norma de mitigação constituir um dever. O mais adequado seria a utilização da expressão burden to mitigate the loss ou, como sugerimos no título do item 2.1.1.3.1., ônus de mitigação. No entanto, para evitar confusão na sua identificação e, principalmente, levando em consideração a sua difusão e consagração pela expressão, continuaremos a utilizar duty to mitigate the loss neste estudo.

${ }^{252}$ LITVINOFF, Saúl. Damages, Mitigation, and Good Faith. Tulane Law Review, New Orleans, v. 73, p. 1161-1195, 1999. p. 1171. 


\section{TÍTULO II - O DUTY TO MITIGATE THE LOSS NO DIREITO INTERNO}

\section{APLICAÇÃO DO DUTY TO MITIGATE THE LOSS}

\subsection{Introdução}

No Título anterior foi estudada a natureza jurídica de ônus da norma de mitigação, como ela se manifesta nos países da common law e os indícios de sua existência no direito romano. Além disso, ficou determinado que o princípio da boa-fé é fundamento do duty to mitigate the loss, pois delimita o exercício de direitos subjetivos, obstando condutas que não se alinhem ao standard por ela determinado. Sendo assim, se o credor não evitar ou mitigar seu prejuízo, estará adotando postura contrária à boa-fé, tendo que arcar com todos os prejuízos decorrentes de seu comportamento inapropriado.

Tais informações, todavia, não são suficientes. É preciso compreender o fenômeno na sua aplicação no direito pátrio, isto é, quais condições devem estar presentes para que haja a incidência da norma de mitigação, o que a diferencia de outros institutos jurídicos e como se relaciona com eles. Este capítulo é dedicado a responder estas indagações.

\subsection{Pressupostos de existência}

A partir de toda a explanação feita até este ponto, é possível extrair três pressupostos para caracterizar o duty to mitigate the loss. São eles: o inadimplemento, a existência de um prejuízo imputável ao devedor e a possibilidade, de maneira razoável, de o credor amenizar os efeitos deste dano ou evitá-lo.

\subsubsection{Inadimplemento}

Sem o inadimplemento, de qualquer espécie obrigacional, não há falar em qualquer responsabilidade. Afinal, ninguém pode se responsabilizar por um problema que sequer 
existe. É necessário que exista uma crise no pacto, em que uma das partes deixe de cumprir plenamente suas obrigações para que surjam os efeitos decorrentes.

Zanetti $^{253}$ nomeia este primeiro pressuposto de inexecução contratual. A ideia não deixa de ser a mesma apresentada, mas a expressão peca pela sua menor abrangência. Quando se diz "inexecução contratual", parece estarmos diante apenas do momento em que o contrato já foi celebrado e está em execução, ignorando as negociações preliminares (período pré-contratual) e o período pós-contratual. A expressão inadimplemento, por sua vez, parece-nos ser mais abrangente, pois trata da inobservância das obrigações de toda a relação obrigacional havida entre as partes.

Igualmente, tratar somente da espécie contratual não nos parece de todo acertado, haja vista que existem outros instrumentos que originam obrigações entre as partes, como no instrumento de doação. Além disso, a norma de mitigação se faz presente também na responsabilidade civil aquiliana, havendo inadimplemento do agente na sua obrigação de não lesar outrem (neminem laedere). Assim, de maneira singela, é melhor nomear este primeiro pressuposto somente como inadimplemento.

O inadimplemento não precisa ser total, bastando que seja parcial. O pressuposto já é tido como preenchido se este inadimplemento, parcial ou não, foi a origem de prejuízos não mitigados pelo credor, sendo que a norma de mitigação impunha este ônus somente a ele.

Pouco importa, igualmente, se o inadimplemento é resultado da falta de cumprimento das obrigações pactuadas, de um cumprimento defeituoso ou da mora. Em todos os casos, há uma inexecução que poderá atrair a incidência da norma de mitigação se existirem prejuízos imputáveis apenas ao credor.

Embora o inadimplemento da obrigação principal constitua a vicissitude mais comum $^{254}$, é certo que a inadimplência de qualquer uma das obrigações, mesmo as acessórias, pode fazer com que surjam prejuízos sujeitos à mitigação do credor. Exemplo claro é no caso da presença de um vício redibitório em um equipamento agrícola que começa a causar danos na fazenda do credor, sem que este tome qualquer atitude para impedir o agravamento de sua situação. O devedor tem a obrigação acessória de se

\footnotetext{
${ }^{253}$ ZANETTI, Cristiano de Sousa. A Mitigação do Dano e Alocação da Responsabilidade. Revista Brasileira de Arbitragem. n. 35. jul./ago./set. 2012. p. 31.

${ }^{254}$ GOMES, Orlando. Contratos. $9^{\mathrm{a}}$ ed. Rio de Janeiro: Forense, 1983. p. 190.
} 
responsabilizar pelos vícios redibitórios ${ }^{255}$ dos produtos postos à disposição no mercado em certo período de tempo.

A mesma lógica se aplica ao caso do cumprimento defeituoso. $\mathrm{O}$ cumprimento defeituoso torna-se um inadimplemento parcial e, em regra, atrai a aplicação da norma de mitigação se preenchidos todos os seus pressupostos. Desse modo, o credor terá a incumbência de não agravar ainda mais a sua situação.

O pressuposto de existência da mora é o inadimplemento em razão do decurso do tempo, do lugar ou da forma que a lei ou convenção estabeleceu (artigo 394 do Código Civil). No caso da mora solvendi, o inadimplemento parte da demora do devedor em saldar sua dívida. Disto, da mesma maneira que ocorre em casos explicados anteriormente, poderão surgir prejuízos imputáveis ao credor que atraem a norma de mitigação.

Curioso, porém, o caso da mora accipiendi a qual quem deu causa à inadimplência foi o próprio credor que recusou injustificadamente o adimplemento da obrigação. Nessa situação, se o devedor oferecer regularmente a prestação devida e constituir o credor em mora, haverá a liberação do devedor de se responsabilizar pela conservação da coisa ${ }^{256}$. O credor é o causador da inadimplência da prestação e todos os prejuízos dali decorrentes ficam por sua conta, não podendo, em hipótese alguma, exigir indenização do devedor.

Para a aplicação da norma de mitigação nesta hipótese, o raciocínio se inverte. Quem era originalmente devedor, passa a ser credor dos danos causados pela mora accipiendi do credor, agora devedor. $\mathrm{O}$ atual credor, a partir deste momento, tem o ônus de se comportar adequadamente para impedir o agravamento do seu prejuízo, tendo em vista que a norma de mitigação não aloca a responsabilidade pelos danos ao atual devedor. Portanto, diferente de ordinariamente as posições jurídicas se manterem, como na ocorrência da mora solvendi, na mora accipiendi o devedor da obrigação é quem assume para si o ônus de mitigar os danos.

O inadimplemento também deve ser analisado pelo ponto de vista pré e póscontratual, haja vista que determinadas obrigações surgem com as negociações preliminares ou se estendem após o cumprimento do negócio. Assim como ocorre no momento da execução do negócio jurídico, havendo inadimplência, por exemplo, do dever de confidencialidade, havendo danos de possível mitigação para a outra parte, esta deverá

\footnotetext{
${ }^{255}$ PANTALEÃO, Leonardo. Teoria Geral das Obrigações: parte geral. $1^{\mathrm{a}}$ ed. Barueri: Manole, 2005. p. 148

${ }^{256}$ DINIZ, Maria Helena. Manual de Direito Civil. $1^{\text {a }}$ ed. São Paulo: Saraiva, 2011. p. 149-150.
} 
se comportar adequadamente para minimizá-los. O mesmo ocorre no caso de rescisão: as obrigações contraídas, se não forem devidamente prestadas e prejuízos advirem que imputem somente uma das partes, haverá atração da norma de mitigação, principalmente por se tratar de uma ruptura em que houve lesão ${ }^{257}$.

\subsubsection{Existência de prejuízo imputável ao devedor}

O segundo pressuposto é a consagração daquilo que se verifica na responsabilidade civil contratual e extracontratual: para a sua existência, é preciso que tenha havido um dano, isto é, uma violação ao ordenamento jurídico - a qual, no caso da responsabilidade contratual, se traduz na violação do que fora pactuado - que repercuta na esfera de direitos de outrem.

Nestes termos, para a incidência da norma de mitigação, é necessária a existência de um prejuízo causado pelo devedor. Só assim é que surgirá para o credor o ônus de impedir o agravamento de seu dano. Sem prejuízo imputável ao devedor, haveria somente uma culpa exclusiva do credor (vítima), o qual deixou de agir com a ordinária e esperada diligência com seu próprio patrimônio. Ou ainda, um caso fortuito ou de força maior. Não há, portanto, resolução do conflito a partir do uso do duty to mitigate the loss.

É importante ressaltar desde logo que o prejuízo agravado ou não evitado pelo credor não se encaixa como um pressuposto do duty to mitigate the loss. Isso porque o dano é consequência da inobservância da norma de mitigação, e não o contrário. Se existe um dano não mitigado, quer dizer que o credor já descumpriu o ônus que possuía e, dessa maneira, todos os pressupostos já estavam preenchidos.

Deve-se, assim, separar bem o momento em que há o inadimplemento com prejuízo imputável ao devedor, solucionado a partir da teoria da responsabilidade civil que atribuirá um dever jurídico de reparação, e o momento em que surge o ônus de mitigação ao credor, oriundo do princípio da boa-fé. Para tanto, é preciso realizar uma análise mais pormenorizada da responsabilidade civil.

${ }^{257}$ GOMES, Orlando. Contratos. $9^{\mathrm{a}}$ ed. Rio de Janeiro: Forense, 1983. p. 210. 


\subsubsection{Responsabilidade civil e o duty to mitigate the loss}

A responsabilidade civil está contida no direito obrigacional, haja vista que a prática de um ato considerado ilícito pode acarretar para o seu autor a obrigação de reparar o dano ${ }^{258}$. Trata-se de obrigação de natureza pessoal, a qual se apresenta como um vínculo que permite ao credor a possibilidade de exigir do devedor o cumprimento de uma prestação $^{259}$. E o devedor, por sua vez, terá o seu patrimônio sujeito a responder pela obrigação, voluntária ou coercitivamente. Portanto, ocorrendo a violação de uma obrigação - que nada mais é do que um dever jurídico de prestação entre determinadas pessoas ${ }^{260}$ nasce consequentemente a responsabilidade, traduzida pelo dever jurídico de indenizar.

Nem sempre a responsabilidade civil se relacionou somente com o patrimônio do devedor. Nos primórdios da humanidade, a ocorrência do dano levava à reação imediata do prejudicado, na forma da vingança privada. De maneira brutal e instintiva, o ofendido reagia contra o causador do dano, reparando o mal com o próprio mal. Posteriormente, a vingança passou a ser mediada, resultando em estruturas normativas como a Lei de Talião, conhecida pela expressão "olho por olho, dente por dente" para demonstrar que, embora existisse um mediador, ainda assim a retribuição era realizada na mesma medida do mal causado.

Até que a vingança é paulatinamente substituída pela composição, com o ofendido sendo compensado economicamente pelo dano sofrido, seja por dinheiro, seja por bens. Deixada de ser uma medida voluntária, passa a ser obrigatória, iniciando-se pela tarifação das indenizações nos Códigos de Ur-Nammu, Manu e da Lei das XII Tábuas ${ }^{261}$.

Entretanto, foi só entre os romanos que a responsabilidade civil e a responsabilidade penal deram os primeiros passos para uma efetiva divisão. O Estado assumiu exclusivamente a função punitiva, surgindo a ação de indenização, separada da esfera penal: os ilícitos de ordem pública eram os de maior gravidade e ensejavam a

\footnotetext{
${ }^{258}$ Em razão da responsabilidade civil fundada no risco, é possível também a responsabilização por atos lícitos. Pelo exercício de uma atividade considerada perigosa, mesmo que o autor não tenha um comportamento anormal e ainda assim cause dano a outrem, estará obrigado a repará-lo pelo risco assumido. (GONÇALVES, Carlos Roberto. Responsabilidade Civil. 11. ed. rev. São Paulo: Saraiva, 2009. p. 31) ${ }^{259}$ Idem, ibidem. p. 2.

${ }^{260}$ GRAU, Eros Roberto. Nota sobre a distinção entre Obrigação, Dever e Ônus. Revista da Faculdade de Direito da Universidade de São Paulo. v. 77, p. 177-183, 1982. p. 179.

${ }^{261}$ GONÇALVES, Carlos Roberto. Responsabilidade Civil. 11. ed. rev. São Paulo: Saraiva, 2009. p. 4-5.
} 
aplicação de uma sanção penal; os ilícitos de ordem privada tinham a intervenção da autoridade para a reparação do dano sofrido pelo ofendido.

Por volta do século III a.C. surge a Lex Aquiliae de damno, a qual estabeleceu as bases da responsabilidade civil extracontratual, estabelecendo a forma pecuniária de indenização do prejuízo ${ }^{262}$. Conforme Gilisen explicita, a Lei Aquília, ao sancionar diversos delitos privados em suas disposições, acabou por servir de base para a jurisprudência alargar o seu alcance, sancionando qualquer dano causado contrariamente ao direito ${ }^{263}$. Além disso, ainda que de modo primitivo, inseriu a noção de culpa por meio da regra da In lege Aquilia, levissima culpa venit.

Fixadas as bases pelos romanos, o direito francês tratou de abandonar o critério da enumeração de casos específicos para a responsabilização e partiu para o estabelecimento de um princípio geral de responsabilidade. Também foi inserida a necessidade de presença inequívoca de culpa do autor: a responsabilidade civil se funda na culpa, generalizando o preceito supracitado da lei aquiliana ${ }^{264}$. E o Código Civil francês acabou influenciando todo o mundo, sendo ainda a base da responsabilidade civil moderna, malgrado já existir previsões, mesmo no direito brasileiro, da responsabilidade civil sem culpa, fundada no risco $^{265}$.

\subsection{Responsabilidade contratual e extracontratual}

O Código Civil brasileiro traz duas espécies de responsabilidade civil, a contratual e a extracontratual. A dualidade de tratamento tem origem principalmente da derivação da responsabilidade: se proveniente de um vínculo obrigacional, diz-se que a responsabilidade é contratual; caso seja da inobservância de uma norma de conduta fixada no ordenamento

\footnotetext{
${ }^{262}$ DINIZ, Maria Helena. Curso de Direito Civil Brasileiro: responsabilidade civil. v. 7, 17. ed. São Paulo: Saraiva. 2003. p. 10.

${ }^{263}$ GILISSEN, John. Introdução histórica ao direito. Tradução por A. M. Hespanha e L. M. Macaísta Malheiros. $2^{\mathrm{a}}$ ed. Lisboa: Calouste Gulbenkian, 1995. p. 751.

${ }^{264}$ GONÇALVES, Carlos Roberto. Responsabilidade Civil. 11. ed. rev. São Paulo: Saraiva, 2009. p. 6.

265 Existem casos em que o legislador criou exceções para a proteção do lesado, prevalecendo a responsabilidade objetiva. O elemento culpa, nestes casos, é afastado, havendo responsabilidade pela simples relação de causalidade entre a ação e o dano. Tal preceito está estampado principalmente no artigo 927, parágrafo único, do Código Civil, facilitando a reação da vítima em face do agente visando à reparação do dano, ou seja, gerando aos infratores o dever de indenização em caso de acidentes oriundos de suas atividades lícitas. Se assim não fosse, a vítima teria que apresentar provas de difícil produção, criando obstáculos para a satisfação de seu direito. Ressalta-se, contudo, que somente a lei pode estabelecer as hipóteses de responsabilidade objetiva, pois a regra geral é a da responsabilidade subjetiva.
} 
jurídico, é extracontratual. A primeira está disciplinada nos artigos 389 a 416. A segunda, nos artigos 186 a 188 e 927 a 954.

A responsabilidade contratual abrange o inadimplemento relativo a qualquer obrigação, como nos casos dos negócios unilaterais ou provenientes de lei. A responsabilidade extracontratual, por sua vez, compreende a violação aos deveres gerais de omissão ou abstenção de causar dano a outrem (neminem laedere) ${ }^{266}$.

Outra diferença consiste no ônus da prova. Na responsabilidade contratual o credor só precisa demonstrar o inadimplemento da obrigação pelo devedor, enquanto que na responsabilidade extracontratual, a vítima terá que provar a culpa do autor do dano (ou o nexo entre a conduta e o dano, no caso de responsabilidade extrancontratual objetiva). Assim, não é necessário que o credor, na responsabilidade contratual, prove a culpa do devedor, mas somente o inadimplemento e o dano sofrido. O devedor é que terá o ônus de afastar a sua culpa e nexo de causalidade de sua conduta, apresentando a ocorrência das excludentes da culpa exclusiva da vítima, caso fortuito ou força maior.

Ainda que existam referidos aspectos que exigem tratamentos diferenciados para as duas espécies de responsabilidade, é certo que as soluções para ambas são basicamente idênticas, pois fazem com que a parte faltosa indenize o prejudicado. Mais ainda, os mesmos pressupostos - que serão trabalhados no item seguinte - devem estar presentes. Por isso, há quem defenda a extinção do tratamento dualista da matéria ${ }^{267}$, já que a mera disposição separada da matéria não tem força suficiente para que as responsabilidades contratual e extracontratual sejam vistas como espécies distintas.

\subsection{Pressupostos da responsabilidade civil}

A partir da leitura do artigo 186 do Código Civil é possível extrair os pressupostos básicos da responsabilidade civil: a conduta comissiva ou omissiva, o dano e a relação de causalidade $^{268}$. Como visto alhures, são pressupostos que servem tanto para a responsabilidade contratual quanto para a extracontratual.

\footnotetext{
${ }^{266}$ GONÇALVES, Carlos Roberto. Responsabilidade Civil. 11. ed. rev. São Paulo: Saraiva, 2009. p. 27 e 29. ${ }^{267}$ Idem, ibidem. p. 28.

${ }^{268}$ Alguns autores, como Gonçalves, consideram a culpa também como um pressuposto da responsabilidade civil. No entanto, seguimos o entendimento de Diniz, o qual posiciona a culpa como fundamento da responsabilidade civil, já que ela pode ora se basear na culpa, ora no risco. Ou seja: quando a
} 
A conduta pode ser positiva ou negativa. Conduta positiva significa a prática de um ato do qual pode resultar o dano. Já conduta negativa é expressão sinônima a não fazer, a não realizar uma ação que, praticada, poderia evitar a ocorrência do dano. Em todo caso, como se trata de conduta voluntária do agente, há o dever de reparação. A ação ou omissão pode ser derivada de ato próprio, de ato de terceiro ou ainda de animais ou coisas inanimadas os quais o agente tenha o dever de guarda ${ }^{269}$.

O dano, por sua vez, pode ser moral ou patrimonial. Trata-se de toda lesão a um bem juridicamente tutelado, que repercuta na esfera financeira ou psíquica do ofendido. Deve ser dotado de certeza, isto é, já ter se concretizado ou que poderia com certeza se concretizar no momento da conduta gravosa.

Por fim, o nexo de causalidade é a relação entre a conduta do agente e o dano sofrido pelo ofendido. Trata-se da relação de causa e efeito, em que a ausência de um dos polos obsta a obrigação de reparar. Não basta a exclusiva ocorrência de apenas o antecedente (conduta voluntária) ou do consequente (dano) ${ }^{270}$.

Este pressuposto da responsabilidade civil é utilizado por certos estudiosos como a origem da norma de mitigação, seja para o âmbito contratual quanto para o extracontratual. Neste diapasão, a partir da observância da existência de um nexo de causalidade entre conduta e resultado danoso, o duty to mitigate the loss surgiria como consequência da verificação se o dano é ou não direto e imediato. No próximo item será realizada uma análise pormenorizada de seus aspectos e da sua insuficiência e inadequação como fundamento do duty to mitigate the loss.

\footnotetext{
responsabilidade civil se fundamenta no risco, não há falar em culpa e, por isso, não se pode considerá-la um pressuposto.

${ }^{269}$ DINIZ, Maria Helena. Manual de Direito Civil. $1^{\text {a }}$ ed. São Paulo: Saraiva, 2011. p. 294-295.

${ }^{270}$ Embora menos comum, convém salientar que é possível a existência de uma responsabilidade civil sem que tenha havido dano. É o caso da cláusula penal que, em determinadas situações, em razão da inexecução contratual, obriga o devedor a pagar a multa convencional sem que o credor tenha experimentado qualquer violação à sua esfera jurídica. "Vejamos um exemplo bem comum: Fernando aluga fita de vídeo, obrigandose à restituição, no dia seguinte às 20:00 horas. Se restituir a fita às 20:01 horas, deverá, a rigor, pagar a multa, e, seguramente, o atraso de um minuto não há de ter gerado dano". (FIÚZA, César. Para uma releitura da teoria geral da responsabilidade civil. Disponível em: http://www.estig.ipbeja.pt/ ac_direito/CFiuza.pdf. Acesso em: 13/01/2014.p. 7)
} 


\subsubsection{A causalidade}

Poder-se-ia cogitar que a incidência da norma de mitigação seria uma consequência da verificação de, havendo um nexo de causalidade entre conduta e resultado, os danos são de natureza indireta e mediata. Neste sentido, não haveria uma análise da possibilidade de o credor evitar o dano, mas se este não é uma consequência direta e imediata do inadimplemento do devedor, assim como disciplina o artigo 403 do Código Civil para configurar a responsabilidade do devedor por perdas e danos. Por se tratar de um dano indireto, o devedor não teria a responsabilidade de indenizar o credor já que se não se trata de consequência necessária. Assim, referida consequência estaria dentro do campo de atuação do credor, que poderia ter mitigado seu prejuízo.

A origem deste entendimento pode ser encontrada em Pothier, jurista que influenciou fortemente a redação do artigo 1.151 do Código Civil francês ${ }^{271}$, entendimento este que fora adotado no ordenamento jurídico brasileiro no artigo 403 do Código Civil. E para exemplificar seu magistério, Pothier traz o caso da compra da vaca pestilenta ${ }^{272}$. Sabendo da doença contagiosa que possuía, um negociante vende uma vaca pestilenta que dissemina a moléstia para todo o rebanho do comprador. Não apenas a vaca comprada morre como também todo o seu rebanho em razão da doença. O comprador, como ficou sem qualquer animal para poder arar e adubar, não pôde cultivar a terra e, consequentemente, não pôde realizar a colheita. Sem possuir fonte de renda, o comprador fica impossibilitado de pagar suas dívidas e tem seus bens sequestrados e vendidos a preço vil.

No pensamento de Pothier, o vendedor é responsável pelos danos da própria vaca e pelo contágio e morte do rebanho, já que se trata de consequência direta e imediata do prejuízo da venda. Contudo, não se responsabiliza pelos danos acerca dos bens que sofreram constrição em razão da impossibilidade de o comprador pagar suas dívidas, já que não se trata de uma consequência absolutamente necessária da morte do rebanho. Afinal, poderia ter evitado referidos danos com a compra de outros gados ou alugando ou subarrendando as terras para que outrem a cultivassem.

\footnotetext{
271 Art. 1.151: Mesmo que a inexecução da convenção resulte de dolo do devedor, as perdas e danos não devem compreender, com relação à perda sofrida pelo credor e ao ganho de que este tenha sido privado, senão o que é uma consequência direta e imediata da inexecução da convenção. (tradução livre do original)

${ }^{272}$ POTHIER, Robert Joseph. Tratado das obrigações. Tradução por Adrian Sotero De Witt Batista e Douglas Dias Ferreira. Campinas: Servanda, 2001. p. 148-149.
} 
Seguindo este entendimento, Alvim defende que a inatividade do comprador é a verdadeira causa dos danos e por isso que não há nexo causal - e, assim sendo, responsabilidade - do vendedor pelos danos decorrentes da falta de cultivo da terra. Houve um fato imputável ao próprio comprador, e isto basta ${ }^{273}$.

Também está presente esta orientação no pensamento de Monteiro ao trazer o exemplo do vendedor de forragens que deixa de entregá-las e os animais do comprador morrem de fome. Para o doutrinador, a culpa é do próprio comprador que não buscou alternativas para a alimentação dos animais. Ou seja, não há nexo de causalidade do vendedor com o resultado morte ${ }^{274}$.

Trata-se da teoria da relação causal imediata que procura explicar o funcionamento do nexo de causalidade. Exige que entre a inexecução da obrigação e o dano haja uma relação de causa e efeito direta e imediata ${ }^{275}$. O problema, reconhecido pelo próprio Agostinho Alvim ${ }^{276}$, é de identificação da causa estranha, precisando se socorrer à necessariedade da causa. Os danos, portanto, só são imputáveis ao autor se sua atuação for necessária para a produção do resultado.

A partir deste entendimento, haveria a transferência de enquadramento legal do duty to mitigate the loss do artigo 422 do Código Civil (ou dos artigos 113 e 187 para o âmbito extracontratual) para o artigo 403, o qual define que as perdas e danos só incluem os prejuízos efetivos e os lucros cessantes por efeito dela direto e imediato ${ }^{277}$, independentemente que a inexecução resulte de dolo do devedor. O princípio da boa-fé deixaria de ser o fundamento, sendo transferido para a responsabilidade civil, como uma consequência do nexo de causalidade.

Esta posição, todavia, encontra diversas dificuldades. Assim como Litvinoff ${ }^{278}$ critica no caso da common law, nem sempre o prejuízo é fruto da relação causal entre credor e devedor, podendo ter outras origens, de nexos causais diversos. A reação da parte

\footnotetext{
${ }^{273}$ ALVIM, Agostinho Neves de Arruda. Da inexecução das obrigações e suas consequências. São Paulo: Saraiva, 1972. p. 356-362.

${ }^{274}$ MONTEIRO, Washington de Barros. Curso de direito civil: direito das obrigações: $1^{a}$ parte. vol. 4. São Paulo: Saraiva, 1988. p. 335.

${ }^{275}$ GONÇALVES, Carlos Roberto. Responsabilidade civil. $11^{\text {a }}$ ed. São Paulo: Saraiva, 2009. p. 588

${ }^{276}$ ALVIM, Agostinho Neves de Arruda. Da inexecução das obrigações e suas consequências. São Paulo: Saraiva, 1972. p. 339.

${ }^{277}$ Vale ressaltar que o artigo 1.151 do Código Civil francês muito se aproxima do artigo 403 pátrio, haja vista que ambos consideram como indenizáveis somente os danos diretos e imediatos resultantes do inadimplemento. Explicita, portanto, a adoção da relação de causalidade por aquele ordenamento jurídico como fundamento da norma de mitigação.

${ }^{278}$ LITVINOFF, Saúl. Damages, Mitigation, and Good Faith. Tulane Law Review, New Orleans, v. 73, p. 1161-1195, 1999. p. 1170.
} 
prejudicada pode ser a própria causa do prejuízo, o que quebraria o nexo causal entre conduta e resultado. E neste escopo, há dificuldade em definir quais fatos realmente são causas para a ocorrência do resultado, quais são realmente necessários para a sua ocorrência. Para tanto, outras teorias tentam explicar também o nexo de causalidade.

Levando em conta a teoria da causalidade adequada (também chamada de teoria das condições qualificadas), somente aqueles fatos necessários e adequados, isto é, aptos e idôneos, poderiam determinar a produção de um evento ${ }^{279}$. Assim, uma atividade considerada lícita e sem que haja abuso da posição jurídica ocupada, não poderia ser considerada adequada como causa de um resultado danoso. A crítica consiste justamente na posição que o juiz ocuparia, tendo que avaliar demasiadamente se houve culpa do autor do fato em análise, criando uma confusão entre análise de causalidade e culpabilidade.

Por outro lado, se for utilizada a teoria da equivalência dos antecedentes causais (conditio sine qua non), a abordagem é a de que causa é toda ação ou omissão sem os quais o resultado não teria ocorrido. Não há aqui verificação de adequação e relevância, pois todos os fatos que deram causa são relevantes desde que indispensáveis para a ocorrência do resultado. Por eliminação hipotética, é conferida a indispensabilidade de cada um dos antecedentes no desdobramento causal. O grande problema desta teoria é definir até que ponto é possível regressar na linha do tempo para definir causas ${ }^{280}$, pois é possível o regresso ao infinito. Desse modo, é preciso fazer uma verificação da culpabilidade para saber se o autor do fato pretérito tinha consciência que poderia causar o resultado gravoso.

As dificuldades que cada uma das teorias enfrentam acabam por trazer empecilhos para a elaboração de uma norma de mitigação. Isto porque nem sempre chegam a conclusões semelhantes ${ }^{281}$ e, mais do que isso, reduzem o duty to mitigate the loss a uma verificação casuística. Além do mais, as teorias têm como óbice os efeitos "diretos e imediatos" do artigo 403 do Código Civil, pois uma causa poderá não trazer efeitos dessa espécie. A jurisprudência, então, teria o papel de verificar os casos em que há nexo de

\footnotetext{
${ }^{279}$ GONÇALVES, Carlos Roberto. Responsabilidade civil. $11^{a}$ ed. São Paulo: Saraiva, 2009. p. 587

${ }^{280}$ Idem, ibidem. p. 586.

281 "As duas teorias podem ser facilmente compreendidas com o seguinte exemplo: A deu uma pancada ligeira no crânio de B, a qual seria insuficiente para causar o menor ferimento num indivíduo normalmente constituído, mas que causou a $\mathrm{B}$, que tinha uma fraqueza particular dos ossos do crânio, uma fratura de que resultou a morte. O prejuízo deu-se, apesar de o fato ilícito praticado por A não ser causa adequada a produzir aquele dano em um homem adulto.

Segundo a teoria da equivalência das condições, a pancada é uma condição sine qua non do prejuízo causado, pelo qual o seu autor terá de responder. Ao contrário, não haveria responsabilidade, em face da teoria da causalidade adequada." (Idem. p. 587)
} 
causalidade e apontar quais causas são suficientemente próximas para preencher o dispositivo legal, com o risco de haver decisões conflitantes para casos semelhantes ${ }^{282}$.

Por fim, cabe ressaltar que reconduzir a mitigação à causalidade impede que a questão seja avaliada sob o prisma correto, qual seja, a valoração da conduta do credor. Ao situar o fundamento da mitigação na cooperação e na boa-fé objetiva, como visto acima, permite-se que os atos tomados pelo credor sejam avaliados axiologicamente de acordo com o que seria socialmente esperado como atitudes honestas e leais de um homem probo. Na formulação da regra de mitigação, essa comparação com o padrão de conduta esperado será fundamental para avaliar a razoabilidade dos esforços empregados pelo credor. O raciocínio que se desenvolve sob a visão de causalidade é outra, menos valorativa da conduta e mais relacionada à natureza dos fatos subsequentes ao inadimplemento, para a identificação do que é causa e efeito ${ }^{283}$.

Além disso, a partir do exemplo da vaca pestilenta, Dias ${ }^{284}$ identifica um problema no uso do nexo de causalidade. Se não existe nenhuma regra que proíba o indivíduo de diminuir o próprio patrimônio, então o prejuízo agravado pela conduta do comprador é um indiferente jurídico. Sendo um indiferente jurídico, não tem como haver a sua qualificação como causa do agravamento, pois qualquer relevância não há. Somente havendo algum substrato que torne a atuação relevante - como o princípio da boa-fé - atribuindo-lhe o status de dever ou ônus é que se torna possível limitar a indenização a ser recebida pelo comprador. Isto acabaria dando outro resultado ao exemplo, responsabilizando o vendedor de má-fé pelos danos indiretos e mediatos, pois inexiste outra causa além da inexecução positiva do contrato ${ }^{285}$.

\footnotetext{
${ }^{282} \mathrm{O}$ que de fato aconteceu no direito francês. Na falta de uma norma de mitigação específica e pelo fundamento na causalidade, coube à jurisprudência francesa analisar caso a caso se os prejuízos havidos pelo credor eram diretos e imediatos e se lhe cabia evitar ou minimizá-los. Consoante citado por Le Pautremat, a causalidade trouxe decisões com diferentes resultados ao Tribunal de Montpellier em 1965 e a Corte de Cassação em 2003. No primeiro, um comerciante que havia sido vítima de acidente automobilístico não foi indenizado pelas perdas que teve em seu comércio, pois havia ficado fechado enquanto se recuperava dos ferimentos. O Tribunal de Montpellier entendeu que a vítima deveria ter agido para evitar os prejuízos e, como assim não fez, a sua omissão foi a causa dos danos à sua loja, não fazendo jus à indenização. No segundo e idêntico caso julgado pela Corte de Cassação, entendeu-se de maneira oposta, fazendo a vítima jus à indenização pelos danos à loja, já que decorreram diretamente do acidente. O comerciante não estava obrigado a mitigar o prejuízo. (LE PAUTREMAT, Solène. Mitigation of damage: a French perspective. International and Comparative Law Quarterly. Londres, v. 55, p. 205-217, 2006)

${ }^{283}$ LOPES, Christian Sahb Batista. A mitigação dos prejuízos no direito contratual. Belo Horizonte, 2011. Tese (Doutorado em Direito). Faculdade de Direito da Universidade Federal de Minas Gerais. p. 165.

${ }^{284}$ DIAS, Daniel Pires Novais. $O$ duty to mitigate the loss no Direito Civil brasileiro e o encargo de evitar o próprio dano. Revista de Direito Privado. Ano 12. n. 45. jan./mar. 2011. p. 106.

${ }^{285}$ Idem, ibidem.
} 
Ademais, considerando que a natureza jurídica do duty to mitigate the loss é de ônus $^{286}$, não é possível falar em responsabilidade. Afinal, a responsabilidade é uma relação obrigacional, sucessiva de um dano, que tem por natureza ser um dever jurídico ${ }^{287}$. Se é dever, logo não pode ser classificada concomitantemente como um ônus. Torna, portanto, inviável fundamentar a mitigação na responsabilidade civil.

Assim, a causalidade, apesar do apelo do direito francês, não pode ser fundamento da norma de mitigação, pois transforma a verificação da mitigação pelo credor em um fator verificável caso a caso. Acaba por abandonar um modelo de comportamento apreciável pelo juiz, tarefa esta que a boa-fé como criadora de standards possibilita. Além disso, a criação de uma solução judicial para o caso concreto pela cláusula geral da boa-fé se torna inócua, pois a importância no caso não é a postura do credor, mas o nexo da ocorrência dos fatos. Ou seja, deixa importantes aspectos axiológicos de conduta honesta e proba de lado para simples verificação da sucessão de fatos, o que pode resultar na existência de decisões judiciais conflitantes sobre casos semelhantes.

\subsubsection{Culpa exclusiva da vítima e culpa concorrente}

Outra possibilidade que se pode cogitar de fundamento para o duty to mitigate the loss seria a culpa exclusiva da vítima ou, em certos casos, a sua culpa concorrente. A análise então passaria a considerar estruturalmente a possibilidade de o credor evitar os danos com as medidas que estavam ao seu alcance. Não agindo desta forma, perderia o direito à indenização tendo em vista o desrespeito à norma de mitigação imposta pela análise da culpa.

São duas hipóteses: o dano como consequência da ação ou omissão da própria vítima, não havendo sequer nexo de causalidade com aquele acusado de ser o agente e o dano como consequência da atuação conjunta - ainda que falte o liame subjetivo entre eles de cooperarem - entre o agente e vítima, sendo causas necessárias para a sua ocorrência. Em ambas há a contribuição da vítima para o efeito danoso, diferenciando-se apenas pela sua atuação individual ou conjunta com outrem.

\footnotetext{
${ }^{286}$ Conforme analisado no Capítulo 2, item 2.1.1.3.1., supra.

${ }^{287}$ Conforme item 3.2.2.1. supra.
} 


\begin{abstract}
Não pode, por isso mesmo, permanecer o direito estranho à circunstância de ser o mal causado uma consequência da atuação da própria vítima. E, dela cogitando, verifica que a contribuição do lesado, na construção dos elementos do dano que sofreu, pode graduar em escala diferente a sua concorrência culposa no evento prejudicial, e, consequentemente, graduar-lhe também os efeitos. Assim é que, se a causa do prejuízo está toda inteira no fato da vítima, ocorre a escusativa da responsabilidade. Se a vítima apenas concorreu para o acontecimento, em cuja elaboração fática se adicionaram a falta da vítima e a falta do acusado, reduz-se a indenização, na proporção em que o lesado concorreu para o dano sofrido ${ }^{288}$.
\end{abstract}

Então, no caso de culpa exclusiva da vítima, inexiste responsabilidade do dito agente. Especificamente tratando da questão do duty to mitigate the loss, o dano sofrido pela falta de mitigação é de responsabilidade total da vítima (credor), que deixou de tomar as atitudes necessárias e adequadas para impedir este resultado.

Quando se está diante da hipótese da culpa concorrente, é necessária a verificação da gradação da culpa da vítima em relação à culpa do agente para a fixação da indenização, haja vista que não há interrupção do nexo causal em razão de o dano agravado ser fruto de contribuição tanto do agente quanto da vítima. É o que preleciona o artigo 945 do Código Civil. Na análise das culpas, verifica-se até que ponto esta pode ser imputada à vítima e a partir disso é fixado o quantum indenizatório proporcional.

Importante deixar claro que o artigo 945, ao se utilizar da expressão "evento danoso", não diz respeito somente à situação de contribuição da vítima ao fato, mas também daquelas em que se dá acerca de sua extensão, isto é, no aumento do dano. Devese compreender a expressão de maneira ampla, para abarcar a concorrência de culpas pelo dano tanto na sua produção quanto no seu agravamento ${ }^{289}$.

O resultado do raciocínio, no entanto, não é adequado à norma de mitigação, por dois motivos. O primeiro deles, exclusivo do caso da culpa concorrente, consiste na necessária concomitância de condutas do agente e da vítima ou até mesmo de o dano ter se iniciado com a conduta da vítima e continuado com a atuação do agente. Ora, a mitigação do prejuízo causado pela vítima (credor), por ordem lógica, é posterior ao dano causado

\footnotetext{
${ }^{288}$ PEREIRA, Caio Mário da Silva. Instituições de Direito Civil - Vol. I. $21^{\text {a }}$ ed. Rio de Janeiro: Forense, 2005. p. 670-671.

289 "Por exemplo: um motociclista que imprudentemente trafega na contramão e é atropelado por veículo conduzido em velocidade acima do limite máximo permitido. Neste caso, o motociclista contribuiu para a ocorrência da colisão (evento danoso) e o art. 945 do CC/2002 indubitavelmente incide para fins de fixação da indenização. Agora, se, diferentemente, o motociclista está parado no sinal vermelho sem capacete e é atropelado, ele não contribuiu para o atropelamento (evento danoso), mas a sua conduta (culposa) de estar sem capacete poderá ter contribuído para a maior extensão (agravamento) dos danos sofridos". (DIAS, Daniel Pires Novais. $O$ duty to mitigate the loss no Direito Civil brasileiro e o encargo de evitar o próprio dano. Revista de Direito Privado. Ano 12. n. 45. jan./mar. 2011. p. 110-111)
} 
pelo agente (devedor). No âmbito da mitigação, a intervenção da vítima só poderá ser posterior à do agente porque é o cenário de impedimento de agravamento do dano. Assim, é impossível que haja concomitância de condutas.

O segundo motivo consiste na necessidade de existir antes da culpa um pressuposto, não podendo aquela ser fundamento deste ${ }^{290}$. A culpa é caracterizada pela inobservância de um standard exigível de comportamento diligente que acaba por contrariar o ordenamento jurídico, sendo por este censurada. Para haver tal censura, é preciso que exista alguma norma de conduta que a fundamente, senão não há falar em culpa. Não sendo, portanto, a estrutura, mas um elemento de um pressuposto para a sua existência, não há como defender a culpa como fundamento da norma de mitigação.

É justamente o contrário: pela existência da norma de mitigação, sedimentada por outro fundamento, é que se pode perquirir a culpa daquela que produz ou agrava o próprio dano. Posicionar a culpa como antecedente é deixá-la manca, pois não possui qualquer base para sua análise de incidência no caso concreto.

Neste sentido, parece ilógica a limitação dos danos da culpa concorrente sem que haja uma norma jurídica anterior que a fundamente. Se não existe uma regra anterior que abrigue a compreensão de que determinada conduta é ilícita e culposa, não há sentido em imputar à própria vítima a responsabilidade pelos danos sofridos. Neste cenário, a causa da configuração do dano acaba por ser apenas do agente.

Por fim, é fundamental a diferença que na culpa concorrente a vítima contribui para o próprio dano criado pelo agente. No duty to mitigate the loss, diferentemente, a vítima não impede os prejuízos decorrentes do dano causado pelo agente. Já na culpa exclusiva da vítima, o agente é o único causador do dano, não havendo qualquer nexo de causalidade entre o dano e a conduta daquele acusado como agente. Nestes termos, não há falar em duty to mitigate the loss, haja vista estar ausente qualquer dano de autoria do agente que enseje a mitigação dos prejuízos dele decorrentes.

Também valem para o caso da culpa concorrente e exclusiva da vítima as mesmas críticas que merecem a causalidade como fundamento. A verificação da exclusividade e concorrência da culpa depende de uma análise do nexo de causalidade e, por isso, a formulação da regra passa a ser casuística, com base jurisprudencial. A valoração da

\footnotetext{
${ }^{290}$ LOPES, Christian Sahb Batista. A mitigação dos prejuízos no direito contratual. Belo Horizonte, 2011. Tese (Doutorado em Direito). Faculdade de Direito da Universidade Federal de Minas Gerais. p. 166.
} 
conduta esperada do credor é deixada de lado, priorizando a sucessão dos fatos, o que em parte contradiz a ideia de culpa de estabelecer standards de comportamento. Além disso, sendo a culpa o fundamento e, por isso, inexistindo norma de conduta anterior, a diminuição do patrimônio pelo seu próprio titular é um indiferente jurídico. Sendo um indiferente jurídico, não existe sentido em perquirir culpa, fazendo com que o raciocínio entre em uma contradição interna. Não havendo uma anterior norma de mitigação, é indevido dizer que o comportamento negligente com seu próprio patrimônio é culposo, pois ao credor cabe dispor, como quiser, do que é seu. O duty to mitigate the loss é pressuposto da culpa, e não o contrário.

\subsection{A experiência da culpa concorrente como fundamento no direito estrangeiro}

A culpa concorrente como fundamento da norma de mitigação é comumente encontrada nos países de civil law. Consoante estudado acima, o credor que não mitiga seus danos é visto como culpado pelo agravamento de sua situação, minimizando o quantum indenizatório a ser pago pelo devedor de acordo com o seu grau de culpa. O foco de análise é bastante diferente daquele encontrado nos países que adotam o common law em razão da adoção da doutrina da evitabilidade como princípio autônomo ${ }^{291}$.

Dos países que adotam o civil law, o direito alemão traz previsão expressa do duty to mitigate the loss no $\$ 254$ do $\mathrm{BGB}^{292}$. Em linhas gerais, o artigo trata das questões atinentes à culpa concorrente, trazendo três hipóteses distintas. Na primeira, aduz a regra da contribuição da vítima na ocorrência do dano, responsabilizando-a conforme a extensão de sua culpa no resultado danoso. Na segunda, trata da necessidade de o devedor avisar o credor da possibilidade da extensão dos danos serem maiores que a usual. Por fim, trata da responsabilidade pela falha em evitar ou reduzir o dano.

\footnotetext{
${ }^{291}$ Vide Título I, Capítulo 1, item 1.2.1., supra.

292 §254 Culpa concorrente

(1) Quando a culpa da pessoa prejudicada contribui para a ocorrência do dano, a responsabilidade pelos danos e a extensão da compensação a ser paga dependem das circunstâncias, em particular, de qual extensão do dano é causada preponderantemente por uma ou pela outra parte.

(2) Isso também se aplica se a culpa da parte prejudicada se restringe a falhar em chamar a atenção do credor para o perigo de um dano de extensão incomum, quando o credor não estava ou não deveria estar ciente do perigo, ou em falhar em evitar ou reduzir o dano. O disposto no artigo 278 se aplica com as necessárias modificações. (tradução livre)
} 
De fato, a legislação alemã compreende a norma de mitigação no próprio âmbito da culpa concorrente, malgrado as críticas já feitas nos itens 3.2.2.2. e 3.2.2.2.1. supra. Além disso, ao delegar a análise da culpa às circunstâncias do caso, o dispositivo acaba transferindo um poder discricionário ao juiz de nos fatos identificar quais são necessários para causar o dano e qual a extensão da culpa de cada um dos envolvidos no resultado gravoso.

Cumpre destacar que o dispositivo em comento não explicita que a conduta mitigadora do credor deverá ser realizada dentro do limite do razoável ${ }^{293}$. Todavia, em se tratando de análise de culpa, é de se esperar que seja a diligência normal exigível em situações semelhantes, consoante o standard de conduta ${ }^{294}$.

No tocante ao direito português, a legislação deu a mesma solução que a alemã no artigo 570 de seu Código Civil ${ }^{295}$. Da mesma maneira, traz junto da regra da culpa concorrente a norma de mitigação, cabendo ao juiz identificar a gravidade das culpas para reduzir ou excluir o dever de indenizar.

O direito italiano traz previsão semelhante ao direito alemão no artigo 1.227 do Código Civil $^{296}$. No mesmo dispositivo legal há tratamento da culpa concorrente e da mitigação do dano, como se aquela fosse fundamento desta. Contudo, embora pareça em um primeiro momento que o direito italiano segue completamente o direito alemão, a leitura mais atenta mostra na verdade uma divergência.

Enquanto o $\$ 254$ do BGB concede à mitigação o mesmo tratamento da culpa concorrente, com a verificação discricionária do magistrado dentro do nexo de causalidade tanto a conduta do agente quanto da vítima, no direito italiano o artigo 1.227 do Código Civil reconhece uma quebra da relação entre causa e consequência, havendo na norma de

\footnotetext{
${ }^{293}$ Conforme pressuposto a ser trabalhado no Título II, Capítulo 4, item 4.3.3. e Capítulo 5 infra.

${ }^{294}$ LOPES, Christian Sahb Batista. A mitigação dos prejuízos no direito contratual. Belo Horizonte, 2011. Tese (Doutorado em Direito). Faculdade de Direito da Universidade Federal de Minas Gerais. p. 56.

${ }^{295}$ Art. 570 (Culpa do lesado)

1. Quando um facto culposo do lesado tiver concorrido para a produção ou agravamento dos danos, cabe ao tribunal determinar, com base na gravidade das culpas de ambas as partes e nas consequências que delas resultaram, se a indemnização deve ser totalmente concedida, reduzida ou mesmo excluída.

2. Se a responsabilidade se basear numa simples presunção de culpa, a culpa do lesado, na falta de disposição em contrário, exclui o dever de indemnizar.

296 Artigo 1.227. Concurso de fato culposo do credor

Se o fato culposo do credor tiver concorrido para causar o dano, o ressarcimento é reduzido de acordo com a gravidade da culpa e a magnitude das consequências daí derivadas.

O ressarcimento não é devido pelos danos que o credor teria podido evitar usando ordinária diligência (2.056 e seguintes). (tradução livre)
} 
mitigação nexo de causalidade somente entre a conduta da vítima e o dano agravado. Não há uma diminuição no dever de indenização, mas exclusão ${ }^{297}$.

Além disso, diferentemente do que ocorre com o direito alemão, o dispositivo italiano prevê expressamente a necessidade de o credor se utilizar da ordinária diligência para impedir os danos evitáveis, sendo estes não passíveis de ressarcimento. Quanto à ordinária diligência, a Suprema Corte italiana já realizou o discrímen entre os danos evitáveis e os danos não evitáveis sendo estes os que exigem uma atividade grave e extraordinária, com gastos consideráveis, assunção de riscos particulares ou de reconhecido sacrifício ${ }^{298}$. Tudo isso com atenção a um princípio de correção (principi di correttezza, por vezes também tratado como dever) e à boa-fé objetiva, reconhecidos também pela Suprema Corte italiana ${ }^{299}$.

\subsubsection{Possibilidade razoável de o credor evitar ou amenizar os prejuízos}

A norma de mitigação não impõe um ônus de o credor evitar ou amenizar todo e qualquer prejuízo decorrente do inadimplemento do devedor. Se assim fosse, nem ao menos seria necessário o duty to mitigate the loss, bastando uma disposição normativa restringindo a responsabilidade do devedor para apenas o inadimplemento. Desse modo, a norma de mitigação não exige a atuação incondicional, mas aquela que se mostre razoável diante das circunstâncias ${ }^{300}$.

A grande dificuldade, contudo, é definir o que seria uma atuação razoável, dada a multiplicidade de situações possíveis que podem surgir. $\mathrm{O}$ direito italiano faz referência à ordinaria diligenza na segunda parte do artigo 1.227 do Código Civil ${ }^{301}$ para estabelecer um limite à indenização a ser paga pelo devedor sem, contudo, trazer uma definição sobre o que ela seria. A doutrina e a jurisprudência então desenvolveram a ideia de evitabilidade,

\footnotetext{
${ }^{297}$ CENDON, Paolo. Commentario al Codice Civile Artt. 2054-2059: Fatti illeciti. Circolazione di veicoli, responsabilità solidale, valutazione, danni non patrimoniali. Milão: Giuffré, 2009. p. 303.

${ }^{298}$ Idem, ibidem.

${ }^{299}$ Idem, ibidem. p. 304.

300 CHRISTENSEN, W. D.; Sharon. Professional Liability and Property Transactions. Sidnei: The Federation Press, 2004. p. 95.

301 Já analisado no item anterior.
} 
sendo as consequências do inadimplemento que o credor poderia ter evitado caso se comportasse com a diligência ordinária esperada ${ }^{302}$.

Portanto, pela análise do que seria evitável ou inevitável, o magistrado, na apreciação do caso concreto, teria a base de um comportamento diligente e, por conseguinte, de quais danos deveriam ser ressarcidos ou não. Neste sentido, a Suprema Corte italiana definiu que o discrímen entre danos evitáveis (não passíveis de ressarcimento) e inevitáveis (passíveis de ressarcimento) se constituem através do ônus de atuar com a diligência ordinária, afastado no caso de a mitigação só poder ser realizada através de atividades arriscadas ou extraordinárias. Estas são compreendidas como gastos de grande monta, riscos específicos ou sacrifícios exagerados, isto é, tudo que não se admite que ocorra ordinariamente ${ }^{303}$.

Levando em consideração que o direito italiano se utiliza da verificação da culpa como fundamento para o duty to mitigate the loss, a estabilização do conceito de ordinaria diligenza é feita pelo acúmulo de casos. Quanto mais situações diferentes são apreciadas pelo Judiciário, mais fixos são os critérios de aferição da norma de mitigação, inspirando segurança àqueles a ela submetidos.

A delimitação do conceito de razoabilidade também pode ser obtida no Draft Common Frame of Reference, de 2009 em seu artigo I.-1:104 ${ }^{304}$ e no artigo $5^{\circ}$ da Common European Sales Law $^{305}$. Quanto a estes, é válida a crítica trazida por Zanetti:

\footnotetext{
São indicadores interessantes e que certamente podem ser manejados com proveito. Não parece, no entanto, que a legislação seja a sede mais adequada para oferecer critérios destinados a precisar um conceito jurídico indeterminado. Isso porque pode ser conveniente recorrer a algum elemento estranho à disciplina legal para reger o caso concreto, providência que, no mínimo, resta dificultada se o intérprete não pretender se distanciar do texto legal ${ }^{306}$.
}

\footnotetext{
302 CENDON, Paolo. Commentario al Codice Civile Artt. 2054-2059: Fatti illeciti. Circolazione di veicoli, responsabilità solidale, valutazione, danni non patrimoniali. Milão: Giuffré, 2009. p. 302.

${ }^{303}$ Idem, ibidem. p. 303.

${ }^{304}$ I.-1:104: Razoabilidade

Razoabilidade deve ser objetivamente determinada, levando em conta a natureza e a finalidade do que está sendo feito, as circunstâncias do caso e quaisquer usos e práticas relevantes. (tradução livre)

305 Art. 5: Razoabilidade

1. Razoabilidade deve ser objetivamente determinada, levando em conta a natureza e a finalidade do que está sendo feito, as circunstâncias do caso e quaisquer usos e práticas de comércio ou profissões envolvidas.

2. Qualquer referência ao que se pode esperar de ou por uma pessoa, ou em uma situação particular, é uma referência para o que pode ser razoavelmente esperado. (tradução livre)

${ }^{306}$ ZANETTI, Cristiano de Sousa. A Mitigação do Dano e Alocação da Responsabilidade. Revista Brasileira de Arbitragem. n. 35. jul./ago./set. 2012. p. 33.
} 
Transportando para o caso brasileiro, verifica-se que o uso da cláusula geral acaba por contornar o problema da aplicação de elementos estranhos à disciplina legal, pois, consoante visto no Título I, Capítulo 2, item 2.1., ela permite a utilização de elementos metajurídicos - não só eles, mas também de elementos jurídicos norteadores, como, no caso, da boa-fé - que servirão como base para a criação, pelo juiz, da regra no caso concreto. Sendo assim, a lei não precisa traçar balizas específicas sobre a razoabilidade de atuação do credor, correndo o risco de deixar situações sem solução específica ou inadequadas diante do caso concreto. Havendo previamente a noção de um comportamento ético derivado da boa-fé, a análise da sucessão dos fatos é apreciada pela postura adotada, isto é, se foi razoável diante das especificidades do caso em tela.

Nestes termos, parece ser inicialmente interessante a utilização do critério da evitabilidade. Verificando o caso concreto, a gama de opções disponíveis ao credor e o comportamento adequado esperado, é possível dizer se o dano sofrido era evitável ou não. Sendo evitável, os prejuízos não podem ser imputados ao devedor, haja vista que o credor tinha o ônus de agir, evitando-os ou mitigando-os. Por outro lado, sendo os prejuízos inevitáveis, o credor nada podia fazer, sendo um efeito próprio da inadimplência. $\mathrm{O}$ devedor, então, é responsável, podendo o credor pleitear a devida indenização.

Ocorre que o critério é insuficiente da maneira como posto pela doutrina italiana. A partir da inadimplência, sem uma verificação em etapas bem definidas, diz-se que o dano é evitável ou inevitável. Todavia, tratar a questão da evitabilidade nesse formato é inverter o raciocínio: diz-se que o dano é evitável para só depois encontrar a justificativa. Em outras palavras, criam-se argumentos para justificar a opção pela necessidade de o credor mitigar o prejuízo, sendo que aqueles deveriam ser desvendados antes de se concluir pela evitabilidade. Propicia o surgimento de decisões em que a argumentação serve para justificar uma conclusão previamente elaborada, isto é, um falso silogismo para tentar fundamentar convicções pessoais do julgador.

Além disso, deixar a análise da razoabilidade puramente numa identificação de danos evitáveis e inevitáveis sem qualquer baliza acaba por ampliar demasiadamente a decisão para a discricionariedade tanto do credor como a do próprio juiz na circunstância de o litígio ser transportado para o foro judicial. Se não houver etapas bem definidas para se chegar a uma conclusão, há o risco de existir um caos para a definição de quando o credor tem que mitigar e qual a sua limitação. 
A depender das convicções pessoais de cada um que ocupe a posição de credor, certas medidas podem parecer capazes e razoáveis para evitar um dano, ou o contrário. E aquele que está convicto de que agiu corretamente, pode ser surpreendido em um processo por estar diante de convicção distinta do juízo. Neste cenário, não é absurdo pensar no surgimento de decisões conflitantes para casos semelhantes, originando uma enorme insegurança jurídica.

Por isso que é preciso o estabelecimento de balizas para a aferição da razoabilidade. É necessária a elaboração de um instrumento que sirva de guia para que tanto o credor quanto o juiz saibam quando uma medida é razoável ou não. Será este guia que iremos propor no Capítulo 4, que chamamos de regra de aferição da razoabilidade.

\subsubsection{Momento para a tomada da medida razoável}

Um problema que também tem que ser resolvido é quanto ao momento em que a medida deve ser tomada. De nada adianta o credor ter o conhecimento de que o prejuízo é evitável, mas não agir no tempo certo. Tornaria sua atitude inócua, desobrigando o devedor de ressarci-lo dos prejuízos havidos com a mitigação. A resposta deve partir dos próprios ditames dos princípios que regem a relação negocial, do princípio da boa-fé e da responsabilidade civil, assim como ocorre comumente numa relação contratual ou extracontratual.

As partes devem se esforçar para impedir a ocorrência do inadimplemento, imprimindo seus melhores esforços para tanto. A celebração de um negócio jurídico impõe a relatividade das obrigações, ficando as partes vinculadas àquilo que celebraram. Neste âmbito, a inadimplência enseja o reequilíbrio da relação negocial, sendo que o inadimplente só se livra da responsabilidade (Haftung) pelo débito (Schuld) na ocorrência de caso fortuito, força maior ou ausência de culpa. Por isso, vislumbrando a possibilidade de haver o inadimplemento, a parte, por força do princípio da boa-fé, tem o dever de informar $^{307}$ a parte contrária para que conjuntamente cheguem a uma solução. Até porque o inadimplemento implica também na quebra dos deveres de lealdade e confiança recíprocas $^{308}$.

\footnotetext{
${ }^{307}$ Vide Título I, Capítulo 2, item 2.1.1.2.4.

${ }^{308}$ Vide Título I, Capítulo 2, item 2.1.1.2.2.
} 
Ocorre que a inadimplência não é o único momento em que a parte deve zelar pela outra. Consoante visto no Título I, Capítulo 2, item 2.1.1.2.1., a boa-fé impõe o dever jurídico anexo de cuidado, através do qual as partes devem zelar tanto pela própria contraparte quanto pelo seu patrimônio em toda a relação negocial. Não se trata de uma violação direta à obrigação principal, pois isto implicaria no inadimplemento, mas do próprio dever que acaba por prejudicar a continuidade da relação ${ }^{309}$. Portanto, vislumbrando a possibilidade de existir uma violação no patrimônio físico, moral ou material da parte contrária, a parte deverá agir para evitar ou minimizar o máximo possível o prejuízo. Não se trata, pois, do inadimplemento da obrigação principal, mas do inadimplemento de deveres anexos e/ou de obrigações acessórias celebradas pelas partes.

O mesmo acontece no caso da responsabilidade extracontratual, embora sobre estruturas diferentes. Ao invés de existir um negócio jurídico como pano de fundo, há o princípio geral de vedação à realização de atos ilícitos. Por tal motivo, aquele que causar dano a outrem, fica obrigado a repará-lo, salvo se encampado por uma das causas excludentes de ilicitude. A consequência desta vedação é um tanto quanto óbvia: deve-se fazer de tudo (ou se omitir de fazer, se for o caso), dentro daquilo que é possível e razoável, para evitar lesar a esfera jurídica de outrem. Havendo a lesão, se também for possível, minimizar o máximo possível para que não se agrave e, por conseguinte, aumente a responsabilidade indenizatória. Por fim, esgotada a relação causal, o agente deve indenizar a vítima proporcionalmente na extensão do dano.

Como se viu, nos dois casos o momento para a tomada de qualquer medida se inicia com o conhecimento do autor do prejuízo. Não é o mesmo, todavia, que o início da responsabilidade pelo dano: esta se inicia a partir do momento que este passa a existir, sem contar a responsabilidade inerente existente o tempo todo de evitar a criação do dano. Neste sentido, tendo ciência que sua conduta causou ou irá causar um prejuízo, o seu autor deve tomar as medidas necessárias para impedir a sua existência ou extensão.

A solução para o duty to mitigate the loss é semelhante. O credor tem o ônus de prestar as medidas adequadas assim que toma conhecimento do prejuízo. Se ele é instantâneo com o inadimplemento, então é a partir dele que as medidas devem ser tomadas para mitigar o dano. Caso seja possível prever a existência de dano com o inadimplemento - ou seja, não é instantâneo - a partir daí o credor já tem a incumbência de começar a tomar as medidas adequadas para preveni-lo.

${ }^{309}$ SILVA, Clóvis Couto e. A obrigação como processo. São Paulo: José Bushatsky, 1976. p. 119. 
O cerne, portanto, está na ciência do credor de que poderá, com notável segurança, haver um prejuízo ou que este está ocorrendo. Sabendo do dano ou da iminência da sua ocorrência, nasce o ônus de realizar as medidas adequadas para evitá-lo ou minimizar o seu agravamento. Não se confunde com a sua responsabilidade advinda da norma de mitigação, pois mesmos aqueles danos que ocorreram antes do seu conhecimento, se eram evitáveis por ter sido à época possível de o credor ter tomado uma medida adequada se fosse mais diligente, deverão ser a ele imputados.

Não se pode confundir também a questão da ciência do prejuízo ou de sua iminência com a efetiva tomada de medidas. Por vezes, a relação entre as partes é complexa a ponto de o credor necessitar realizar estudos, acumular informações, negociar a celebração de novos contratos, dentre outras medidas preparatórias para iniciar a mitigação do dano ${ }^{310}$. Em situações como estas, a reação do credor poderá não ser imediata e desta qualidade não se pode exigir. Não se pode generalizar levando em consideração apenas o tempo da concretização da medida, mas também todo o zelo do credor por conta da complexidade do caso. Sabendo do dano ou sua iminência e adotando uma postura apta a realizar uma medida razoável de mitigação, pode-se dizer que o credor a adotou no momento correto.

Interessante discussão se situa nas obrigações a termo, já que poderia se cogitar acerca de responsabilidade das partes de observarem o duty to mitigate the loss antes do prazo de vencimento. Honnold ${ }^{311}$ traz exemplo que auxilia no desenvolvimento da resposta para o questionamento, ainda que baseado na Convenção das Nações Unidas sobre Compra e Venda Internacional de Mercadorias (CISG) ${ }^{312}$.

No dia $1^{\circ}$ de junho o contratante "A" celebrou contrato com o contratante " $\mathrm{X}$ " para que este produzisse dez mil chapas de aço em $1^{\circ}$ de agosto pelo valor de 50 por chapa. "A" precisava das chapas para a sua produção. No dia $1^{\circ}$ de julho, " $\mathrm{X}$ " entrou em contato com "A" avisando que não conseguiria entregar as chapas no dia $1^{\circ}$ de agosto, nem mesmo em data posterior próxima do termo estipulado e que " $\mathrm{A}$ " deveria procurar outro fornecedor. Mesmo havendo na região outro fornecedor que produziria as chapas de aço pelo mesmo

\footnotetext{
310 BATES, Paul J. A Mitigation of Damages: A Matter of Commercial Common Sense. Advocate's Quarterly, v. 13, n. 3, jan. 1992, p. 273-307. p. 285.

${ }^{311}$ HONNOLD, John O. Uniform Law for International Sales under the 1980 United Nations Convention. $3^{\mathrm{a}}$ ed. 1999. p. 458-461. Disponível em http://www.cisg.law.pace.edu/cisg/biblio/honnold.html. Acesso em 07/02/2014.

${ }^{312}$ Para maiores detalhes sobre este tratado internacional, incorporado ao ordenamento jurídico brasileiro, ver o Título III, Capítulo 6, infra.
} 
valor e qualidade, “A”, inexplicavelmente, não o procurou. Por conta da falta do produto, "A" teve que encerrar suas atividades no mês de agosto e, em razão disso, propôs ação contra "X" pelas perdas que teve no período de inatividade. "X" argumentou, então, que “A” não tomou as medidas razoáveis para mitigar o dano.

Honnold defende que há incidência do duty to mitigate the loss no caso. Como "A" tinha alternativas para mitigar o dano, " $X$ " não pode ser responsabilizado. " $X$ " avisou definitivamente que não entregaria as chapas de aço no termo contratual estipulado e " $\mathrm{A}$ " teria várias alternativas previstas na própria CISG - como a suspensão da prestação prevista no artigo 71 ou a declaração de rescisão do artigo 72 - para evitar ou reduzir seu prejuízo. Logo, como não tomou qualquer atitude para evitar o prejuízo, não pode ser indenizado pelos danos que sofreu.

Trazido o exemplo para o contexto do direito interno, a conclusão não é diferente. A norma de mitigação não impõe apenas que haja minimização do dano, mas também que o credor possa efetivamente evitá-lo. Desse modo, sabendo de antemão que seguramente haverá inadimplemento por parte do devedor (anticipatory breach), o credor poderá adotar medidas razoáveis para a mitigação do prejuízo, impedindo efetivamente que este ocorra. A solução, dessa maneira, não diverge daquela traçada como regra geral para o momento em que o credor tem o ônus de tomar a medida adequada: assim que ele tiver ciência da efetiva ocorrência ou iminência do dano, haverá a incidência do duty to mitigate the loss, recaindo-lhe o ônus de evitar ou minimizar os danos evitáveis.

Ainda que de maneira adiantada, o inadimplemento ainda é pressuposto para a existência da norma de mitigação. Afinal, é certo que existirá, pois garantido pela postura do devedor evidentemente em rota de colisão com o interesse da execução do negócio jurídico celebrado. A norma de mitigação não obriga o credor a aguardar pacientemente a efetiva ocorrência do dano (ou como Chengwei ${ }^{313}$ diz, "sentar e esperar"), ou seja, que tenha seu patrimônio prejudicado para que só assim possa agir.

313 CHENGWEI, Liu. Remedies for Non-performance: Perspectives from CISG, UNIDROIT Principles \& PECL. Setembro de 2003. Disponível em: http://www.cisg.law.pace.edu/cisg/biblio/chengwei-77.html. Acesso em 07/02/2014. 


\subsection{Perdas e danos como pressuposto de exigibilidade processual}

Diante do inadimplemento do devedor, é dado ao credor alternativas para que tenha seu crédito satisfeito ou, ao menos, seja compensado pelos prejuízos que sofreu. Com efeito, a legislação brasileira permite que o credor opte, quando possível, pela via que acredita melhor assegurar o seu direito e atender aos seus interesses.

Tal faculdade jurídica advém e não está livre das limitações impostas pelos princípios da satisfatividade, da utilidade e da especificidade, próprios da tutela jurisdicional executiva. O princípio da satisfatividade sendo entendido como uma limitação à atuação do juiz na execução, para que atenda somente à satisfação do direito do credor, ou seja, sem que haja constrições desnecessárias no patrimônio do devedor. O princípio da utilidade para que a execução seja útil ao credor, não servindo somente de imposição de um castigo ao devedor. E o princípio da especificidade para propiciar ao credor especificamente aquilo que obteria com o cumprimento da obrigação ou prestação equivalente $^{314}$.

Quanto a este último princípio, é pertinente salientar a preferência da legislação pela execução in natura. Presume-se que o credor tenha interesse no adimplemento da obrigação originalmente pactuada, ao invés da sua substituição por perdas e danos ou que terceiro realize a prestação no lugar do devedor. Neste sentido, a própria legislação processual civil determina que o juiz imponha sempre que possível a tutela específica, condenando o devedor a cumprir a obrigação de dar, fazer ou não fazer nas especificações judicialmente assinaladas.

Nas obrigações de fazer e não fazer, o artigo 461 do Código de Processo Civil preceitua que o juiz concederá a tutela específica da obrigação ou, se procedente o pedido, determinará providências que assegurem o resultado prático equivalente ao do adimplemento. A preferência, como se vê, é do cumprimento da obrigação originalmente pactuada, tendo como alternativa, caso haja recusa do devedor, a execução à sua custa, conforme artigo 633 do mesmo diploma legal. Estas não são as únicas opções as quais o credor pode utilizar. O parágrafo primeiro do artigo 461 e o final da redação do artigo 633 permitem a conversão da obrigação de fazer ou não fazer em indenização por perdas e

314 THEODORO JÚNIOR, Humberto. Curso de Direito Processual Civil - Processo de Execução e Cumprimento da Sentença, Processo Cautelar e Tutela de Urgência - Vol. II. 44 ${ }^{\mathrm{a}}$ ed. Rio de Janeiro: Forense, 2009. p. 121-122. 
danos, se assim desejar o credor ou se a obtenção do resultado prático das prestações se tornar inadequado ou impossível.

A regra para as obrigações de dar não se distancia muito da de obrigação de fazer ou não fazer. O artigo 461-A do Código de Processo Civil aduz que o juiz fixará prazo para a entrega da coisa. A conversão em perdas e danos ocorre por aplicação do parágrafo primeiro do artigo 461, do modo como autoriza o parágrafo terceiro do artigo 461-A. Estas englobarão tanto o valor da coisa (não entregue, deteriorada, não encontrada ou não reclamada do poder de terceiro adquirente) quanto o que o credor efetivamente perdeu e razoavelmente deixou de ganhar.

Pela verificação do Código Civil, também é nítida a preferência pelo cumprimento da obrigação em detrimento, como alternativa, da conversão em perdas e danos. $\mathrm{O}$ artigo 947 dispõe que se o devedor não puder cumprir a prestação na espécie ajustada, substituirse-á pelo seu valor, em moeda corrente.

Percebe-se assim que a preferência é sempre do cumprimento da obrigação em si, tendo como alternativa a conversão em perdas e danos. Se não há a conversão, perdas e danos acompanham a execução forçada da prestação inadimplida, para englobar os demais prejuízos havidos pelo credor. É neste escopo que se pode falar em uma norma de mitigação.

Havendo o cumprimento da obrigação em espécie, não há hipótese em que se possa exigir uma redução do agravamento do dano por parte do credor. Afinal, não foi requerida a reparação de perdas e danos suportados pelo credor - mas não evitados -, mas tão somente o cumprimento da obrigação pactuada. Não havendo, portanto, a consequência gravosa ao credor (ou por ele não alegada ou exigida), não há incidência da norma de mitigação.

A diferença se encontra, contudo, na exigência conjunta do cumprimento da obrigação com perdas e danos ou puramente das perdas e danos. Neste caso, abre a possibilidade de incidência do duty to mitigate the loss, já que a indenização requerida pelo credor pode advir de danos evitáveis, os quais cabiam a ele evitar ou minimizar. Neste sentido, mesmo que haja a execução in natura, caberá a discussão acerca dos prejuízos requeridos adicionalmente pelo credor.

Oportuno notar que a Convenção de Viena enfrentou e chegou à solução idêntica para o mesmo problema quando da elaboração da Convenção das Nações Unidas sobre 
Contratos de Compra e Venda Internacional de Mercadorias (CISG). O artigo 77 dispõe que caso o credor falhe em tomar medidas de mitigação das perdas, o devedor inadimplente poderá pedir a redução das perdas e danos em proporção igual ao montante da perda que poderia ter sido mitigada. Não existe também para este tratado internacional a possibilidade de discussão da incidência do duty to mitigate the loss se o litígio não envolve perdas e danos ${ }^{315}$.

Assim, pode-se dizer que o pleito por perdas e danos, seja isolada, seja cumulativamente requerido com a execução in natura, se traduz como um pressuposto de exigibilidade processual. Consoante já desenvolvido anteriormente ${ }^{316}$ não se constitui o duty to mitigate the loss um dever, mas sim um ônus, já que não é algo exigível por prejudicar apenas o patrimônio do credor e que nem de maneira reflexa atinge o devedor. Todavia, a partir do momento que o credor passa a cobrar do devedor pelos danos que poderia ter evitado ou minimizado, abre a possibilidade para este de questionar e apontar judicialmente que o credor não cumpriu seu ônus.

Neste diapasão, o ônus da prova de inobservância do duty to mitigate the loss é do próprio devedor na ação indenizatória. Ele é quem terá que apontar que o credor não mitigou seu prejuízo, como fato impeditivo ou modificativo do direito deste, nos termos do artigo 326 do Código de Processo Civil. E em réplica o credor terá que demonstrar estar incorreta a leitura feita pelo devedor do caso, evidenciando que os prejuízos eram inevitáveis ou, caso entenda ser conveniente, anuir com os argumentos do devedor e só reforçar as razões daquelas perdas e danos que efetivamente foram inevitáveis.

Os danos evitáveis que o credor tenta imputar ao devedor são unicamente imputáveis a ele mesmo e, por serem exigidos somente na forma de perdas e danos, é possível a apreciação judicial da exclusão deles da responsabilidade do devedor. Ao se afirmar que as perdas e danos constituem um pressuposto de exigibilidade processual, não se está dizendo que o duty to mitigate the loss é exigível. Na verdade, significa que o único cenário em que o devedor pode questionar o cumprimento da norma de mitigação pelo credor é quando demandado por perdas e danos. Sendo assim, só se pode falar de duty to mitigate the loss quando está presente nos pedidos a conversão da obrigação em perdas e danos ou a sua cumulação com a execução in natura.

\footnotetext{
${ }^{315}$ Vide a respeito o Título III, Capítulo 6, item 6.3., infra.

${ }^{316}$ Vide Título I, Capítulo 2, item 2.1.1.3.1., supra.
} 


\section{A REGRA DE AFERIÇÃO DA RAZOABILIDADE: AS CONSEQUÊNCIAS JURÍDICAS DO DUTY TO MITIGATE THE LOSS}

\subsection{Introdução}

No capítulo anterior ficaram definidas importantes balizas e conceitos para a aplicação do duty to mitigate the loss no ordenamento jurídico pátrio. Com a sua recepção através do princípio da boa-fé - consoante visto no Título I, Capítulo 2 -, a norma de mitigação deve ser compreendida como um ônus. Para que seja indenizado dos prejuízos que sofreu, o credor tem que agir conforme o duty to mitigate the loss, mas esta conduta não pode lhe ser imposta ou exigida pelo devedor. A inobservância do ônus de mitigar só atinge o patrimônio do próprio credor, já que terá que arcar com todos os prejuízos decorrentes.

Para tanto, alguns pressupostos, denominados neste estudo como de existência, devem estar presentes. Eles são três: inadimplemento do devedor, existência de prejuízo imputável ao devedor e a possibilidade razoável de o credor evitar ou amenizar os prejuízos. Caso todos estejam presentes, incumbe ao credor mitigar seu dano e, posteriormente, exigir do devedor indenização pelas despesas que incorreu observando o pressuposto específico de exigibilidade processual de na ação judicial pleitear perdas e danos.

O ônus, contudo, não é absoluto. O seu cumprimento depende da verificação se o dano é evitável ou inevitável pelo credor, isto é, se está dentro da sua possibilidade razoável de atuação para mitigá-lo. Ocorre que deixar a análise da razoabilidade puramente numa identificação de danos evitáveis e inevitáveis sem qualquer baliza acaba por ampliar demasiadamente a decisão para a discricionariedade tanto do credor como a judicial.

Se não houver etapas bem definidas para se chegar a uma conclusão, há o risco de existir um caos para a definição de quando o credor tem que mitigar e qual a sua limitação. A depender das convicções pessoais do ocupante da posição de credor, certas medidas podem parecer razoáveis para mitigar o dano, ou justamente o contrário. E o credor, mesmo convicto de que agiu corretamente, pode ser surpreendido em um processo por estar diante de convicção distinta do juízo. Consequentemente, não é absurdo pensar no surgimento de decisões conflitantes para casos semelhantes ou, pior ainda, decisões em que 
a argumentação serve para justificar uma conclusão previamente elaborada, isto é, um falso silogismo para tentar justificar convicções pessoais do julgador.

Neste cenário é que sugerimos a aplicação do que chamamos de regra de aferição da razoabilidade, a ser desenvolvida neste capítulo.

\subsection{Uma nova proposta: a regra de aferição da razoabilidade}

Propõe-se que para o aferimento da razoabilidade do proceder, ou seja, se o dano era evitável ou inevitável, que se cumpram etapas sequenciais. A inspiração para a criação desta regra partiu inicialmente do Restatement (Second) of Contracts, trabalho acadêmico do direito norte-americano com princípios gerais da common law sobre contratos, muito seguido pelas Cortes estadunidenses. Em seu $\$ 350^{317}$ dispõe que os danos não são ressarcíveis pelas perdas que a parte prejudicada poderia ter evitado sem risco, ônus ou desonra. Dessa maneira, o risco foi encarado como uma medida perigosa; o ônus e a desonra, como medida onerosa.

Além disso, o desenvolvimento por nós da regra de aferição da razoabilidade foi inspirado na proposta de $\operatorname{Hillman}^{318}$ de modelos de questões a serem respondidas afirmativamente pelo credor para que seja razoável a celebração de um novo contrato com o devedor como medida razoável para mitigação dos prejuízos ${ }^{319}$ :

\footnotetext{
1. Pode a aceitação da nova oferta reduzir os prejuízos?

2. Pode a parte prejudicada aceitar a nova oferta?

3. É a nova oferta da parte inadimplente a melhor disponível?

4. É a parte prejudicada livre para buscar seus direitos sobre o contrato original mesmo aceitando a nova oferta?

5. Pode a parte inadimplente providenciar garantia adequada que cumprirá sua obrigação?
}

\footnotetext{
${ }^{317} \S 350$. Evitabilidade como limitação das perdas e danos

(1) Exceto conforme estabelecido na Subseção (2), as perdas e danos não são indenizáveis pela perda que a parte prejudicada poderia ter evitado sem indevido risco, ônus ou desonra.

(2) A parte prejudicada não está impedida de ser indenizada pela regra referida na Subseção (1) na medida em que fez esforços razoáveis mas sem sucesso para evitar a perda (tradução livre do original)

318 HILLMAN, Robert A. Keeping the Deal Together After Material Breach: Common Law Mitigation Rules, the UCC, and the Restatement (Second) of Contracts. University of Colorado Law Review. v. 47, p. 553-615, 1976. p. 598.

${ }^{319}$ Vide a análise pormenorizada deste pensamento no Título I, Capítulo 1, item 1.2.3.1.1.
} 
Só que com a regra de aferição da razoabilidade desenvolvemos um grau de maior generalidade, aplicável não apenas ao caso específico da celebração de um novo contrato, mas a toda e qualquer medida a ser tomada pelo credor. Dessa maneira, o credor e o juiz garantem uma maior segurança de que determinada medida é razoável para o duty to mitigate the loss.

A organização da regra, por sua vez, é inspirada pela regra da proporcionalidade desenvolvida por Robert Alexy. Nela, o crivo da proporcionalidade deve se pautar pelos critérios da adequação, necessidade e proporcionalidade em sentido estrito. Para ser aprovada pelo critério da adequação, a "medida deve ter como objetivo um fim constitucionalmente legítimo, que, em geral, é a realização de outro direito fundamental $^{320}$." É a verificação inicial e singela se a medida adotada fomenta o fim almejado. Se for adequada, passa-se ao segundo critério: o da necessidade. Quanto a este, é preciso verificar se o fim almejado não pode ser alcançado por medida menos gravosa, isto é, que limite menos o direito fundamental atingido por ela. Sendo a medida necessária, passa-se ao último critério: o da proporcionalidade em sentido estrito. Este último verifica se pelo sopesamento entre os direitos envolvidos não houve uma exagerada limitação a um dos direitos, injustificável tendo em vista o objetivo perseguido pela medida ${ }^{321}$.

Com a conjugação e reflexão sobre tais entendimentos, foi possível a elaboração de etapas previamente definidas, as quais servem, assim como a regra da proporcionalidade, como estruturas formais de pensamento para auxiliar a tomada de decisão do credor e do juiz. Então, adotou-se em primeiro lugar a etapa da adequação (tal como ocorre na regra da proporcionalidade, mas com algumas especificidades a serem trabalhadas a seguir) e logo em seguida da periculosidade e da onerosidade (inspiradas nos questionamentos de Hillman).

A regra está divida em duas partes, haja vista que a análise do credor é diferenciada temporalmente da do magistrado. Assim, enquanto aquele verifica o que poderá ser feito para evitar ou minimizar o prejuízo, este aprecia o que foi feito. A análise do credor se projeta para o futuro, e a do juiz, para o passado. A primeira parte, então, é própria do credor, o qual verificará a adequação, periculosidade e onerosidade da medida a ser

\footnotetext{
${ }^{320}$ SILVA, Virgílio Afonso da. Direitos Fundamentais conteúdo essencial, restrições e eficácia. $2^{\circ}$ ed. São Paulo: Malheiros, 2010. p. 169-170

${ }^{321}$ Idem, ibidem. p. 169-179.
} 
adotada. A segunda parte é própria do magistrado, que também verificará cada uma destas etapas, mas também terá que passar pelo seu crivo outras duas, da eficiência e da lucratividade, que serão desenvolvidas adiante.

Portanto, feitos estes esclarecimentos iniciais, passa-se a seguir a desenvolver cada uma das partes da regra.

\subsubsection{A primeira parte da regra de aferição da razoabilidade}

A primeira parte da regra de aferição da razoabilidade é exclusiva do credor, já que este verificará qual medida razoável poderá adotar para mitigar o seu prejuízo. Para tanto, deverá apreciar se a medida que imagina razoável é adequada e não perigosa e não onerosa.

Medida adequada é aquela que se enquadra no propósito determinado. Não precisa ser um encaixe perfeito, do qual se obtém o resultado ideal. É adequada desde que pareça ser o recomendável para a situação, guardadas as especificidades do caso. Deve, simplesmente, fomentar o fim almejado. O grau de eficiência não é medido neste momento, e sim, quando da verificação do quantum indenizatório ${ }^{322}$. Assim, ainda que não consiga conter completamente o dano, era a medida que devia ser tomada.

Portanto, uma situação pode conter uma gama de medidas adequadas. Para impedir o perecimento de certo produto, o credor pode tanto se utilizar das máquinas frigoríficas que possui quanto contratar uma empresa para ser depositária deles. Ambas as medidas são adequadas, mas isso não significa que todas elas podem ser adotadas pelo credor, já que outras possuem vedações diante dos demais critérios de apreciação, como a periculosidade e a onerosidade. O preenchimento do critério da medida adequada é puramente a possibilidade de a atuação do credor ensejar a mitigação, independentemente de ela ser a mais indicada ou não para o caso, pois tal avaliação é realizada em etapa seguinte.

Seu conceito, portanto, aproxima-se bastante do filtro da adequação da regra da proporcionalidade desenvolvida por $\mathrm{Alexy}^{323}$ e dos dois primeiros questionamentos

\footnotetext{
${ }^{322}$ Vide item 4.2.2.1. infra.

${ }^{323}$ SILVA, Virgílio Afonso da. Direitos Fundamentais conteúdo essencial, restrições e eficácia. $2^{\circ}$ ed. São Paulo: Malheiros, 2010. p. 169-170.
} 
desenvolvidos por Hillman na análise de celebração de um novo contrato como operação substitutiva $^{324}$.

Medida perigosa se refere à exposição descabida da vida ou reputação a um risco. Só que não se trata, assim como os demais elementos, de um critério fechado. A natureza de cada uma das atividades, bem como a condição de cada pessoa, atribui graus diferenciados de responsabilidade e cuidado, exigindo medidas diferenciadas. Assim, aquele que trabalha com produtos alimentícios não pode se responsabilizar da mesma forma que aquele que trabalha com pólvora. Enquanto que o primeiro, em tese, não tem a expertise necessária para o controle de produtos inflamáveis, o segundo não pode se eximir desta responsabilidade. Impedir o agravamento do dano para o primeiro é exigir uma medida perigosa, em descompasso com a razoabilidade.

Esta etapa foi inspirada principalmente no $\$ 350$ do Restatement (Second) of Contracts quando não considera razoável uma medida que acarrete risco ao credor. $\mathrm{O}$ risco, no caso da regra de aferição da razoabilidade, foi interpretado como um risco à vida, inaceitável de ser exigido de alguém para mitigar um prejuízo.

A medida onerosa, por sua vez, é aquela que causa despesas que superam o valor do prejuízo, que ultrapassem o montante que o credor pode bancar em razão da sua condição financeira ou atinjam sua reputação. Ora, se a medida para evitar ou minimizar o dano se mostra mais onerosa que o próprio dano, não há motivação legítima para o credor agir conforme a norma de mitigação. Suas despesas serão superiores aos danos e, por isso, se trata de um caso de dano inevitável, do qual nasce o direito à indenização.

Neste ponto, é preciso fazer uma observação. É preciso levar em conta que o credor pode achar interessante a situação, para que, ao cobrar o devedor pelas despesas havidas com a mitigação, puna-o pelo seu inadimplemento. Esta não é definitivamente uma postura em consonância com o princípio da boa-fé, pois o agir tem o nítido objetivo de prejudicar. Não será o credor nesta hipótese indenizado, já que com a mitigação acabou, na verdade, incrementando o prejuízo. Ou seja, ao invés de o credor melhorar sua situação, ele fez justamente o contrário: simulou cumprir a norma de mitigação para poder cobrar do devedor um valor indenizatório maior. Não terá, neste caso, direito à indenização.

\footnotetext{
${ }^{324}$ HILLMAN, Robert A. Keeping the Deal Together After Material Breach: Common Law Mitigation Rules, the UCC, and the Restatement (Second) of Contracts. University of Colorado Law Review. v. 47, p. 553-615, 1976. p. 598. Vide Título I, Capítulo 1, item 1.2.3.1.1.
} 
Como dito, também é caso de medida onerosa se o credor não dispuser de meios para suportar os gastos com a medida a ser tomada para evitar ou mitigar o prejuízo. Afinal, não se pressupõe que os recursos financeiros sejam ilimitados pelo simples fato de se tratar do credor, principalmente por ter sido prejudicado com o inadimplemento do devedor $^{325}$. Por isso, exigir esforços além daqueles possíveis pela saúde financeira do credor é inviável, tornando a medida onerosa.

Da mesma maneira, enquadra-se como onerosa a medida que afetará a reputação do credor $^{326}$. Neste sentido, como a medida poderá atingir o patrimônio extrapatrimonial do credor, afetando o seu bom nome no mercado, as relações interpessoais ou até mesmo a imagem que possui perante a sociedade, ele não estará obrigado a agir.

Tanto os conceitos das etapas de verificação se a medida é perigosa ou onerosa tiveram inspiração nos demais questionamentos formulados por Hillman ${ }^{327}$, bem como no $\$ 350$ do Restatement (Second) of Contracts, quando trata de ônus ou desonra como excludentes da razoabilidade da medida.

Esclarecidos estes conceitos, à formulação da regra. A primeira etapa a ser cumprida é a da adequação. Deverá ser questionado se a medida a ser tomada é adequada ao caso. Caso a resposta seja positiva, passa-se para a etapa seguinte. No caso de negativa, o dano já é de pronto inevitável, pois se de todas as medidas aquela que se mostrou mais recomendável não é adequada, não há falar em ônus de mitigação. Ou então o credor se equivocou em sua avaliação, devendo repensar para pretender adotar uma medida adequada e reiniciar a reflexão pela regra de aferição da razoabilidade.

A segunda pergunta que deve ser feita é em relação à onerosidade e periculosidade. Se a medida é perigosa e onerosa, não se aplica a norma de mitigação ao caso, mesmo quando a medida for perigosa ou onerosa. O dano é inevitável. Por outro lado, não sendo a medida perigosa nem onerosa, como ela também é adequada, o dano é evitável pelo credor. Sendo assim, incide a norma de mitigação à hipótese.

É claro que a regra aqui demonstrada não traz uma resolução definitiva para todas as situações, até porque isto contrariaria a abertura do sistema causada pela adoção da

${ }^{325}$ BATES, Paul J. A Mitigation of Damages: A Matter of Commercial Common Sense. Advocate's Quarterly, v. 13, n. 3, p. 273-307, jan. 1992. p. 291.

${ }^{326}$ Caso interessante que retrata bem esta questão é o Banco de Portugal v. Waterlow \& Sons Ltd [1932] A.C. 452 (H.L.), tratado no Título I, Capítulo 1, itens 1.2.3. e 1.2.3.3.

${ }^{327}$ HILLMAN, Robert A. Keeping the Deal Together After Material Breach: Common Law Mitigation Rules, the UCC, and the Restatement (Second) of Contracts. University of Colorado Law Review. v. 47, p. 553-615, 1976. p. 598. Vide Título I, Capítulo 1, item 1.2.3.1.1. 
cláusula geral da boa-fé. No entanto, serve para trazer maior racionalidade à identificação pelo credor de quando incidirá a norma de mitigação, sem que cause uma restrição indevida da sua discricionariedade na escolha da medida a ser tomada.

Importante também diferenciar a regra aqui exposta da que será apresentada no capítulo seguinte. Enquanto esta diz respeito ao momento decisório do credor de adotar certa medida para mitigar o dano ou não, a regra seguinte, vinculada às consequências jurídicas, trata da apreciação do juiz se o credor avaliou corretamente a hipótese fática.

Não é impossível que determinada situação precise que seja tomada mais de uma medida para a mitigação do dano. Diante deste contexto, a avaliação da razoabilidade da atuação pelo credor deve ser realizada a cada medida, podendo acontecer de certos danos serem evitáveis enquanto que outros não são. A aplicação das etapas permite que o credor avalie melhor - mas, por óbvio, não definitivamente - se cada medida que pode ser tomada é adequada e não apresenta perigo ou onerosidade.

Em síntese, a primeira parte da regra traz dois simples questionamentos para a definição da evitabilidade do dano:

a) A medida a ser tomada é adequada? Se sim, passa-se para a etapa seguinte. Se não, o dano é inevitável ou a alternativa escolhida é equívoca. Logo, o credor não tem o ônus de mitigar o dano ou precisa refletir melhor para identificar a medida adequada ao caso;

b) A medida a ser tomada é perigosa ou onerosa? Se sim, o dano é inevitável, o credor não tem o ônus de mitigar. Se não, o dano é evitável, incidindo a norma de mitigação.

\subsubsection{A segunda parte da regra de aferição da razoabilidade}

A primeira parte da regra de aferição da razoabilidade trata apenas da verificação pelo próprio credor se na situação em que se encontra recai-lhe o ônus de mitigar. Será determinado por ele mesmo se o prejuízo atual ou iminente é evitável ou inevitável.

Passado este momento e não havendo um acordo com o devedor em relação à indenização que este deverá pagar, o credor buscará em juízo a solução para o caso. Se propuser ação de indenização por perdas e danos, o credor terá cumprido o pressuposto de 
exigibilidade processual $^{328}$ e abrirá a possibilidade de discussão do correto cumprimento do ônus de mitigação. A apreciação judicial inaugura a segunda parte da regra de aferição da razoabilidade, tendo em vista que agora o magistrado irá verificar, conforme as alegações e provas constantes nos autos, se a medida adotada - ou não, se for o caso de inexistir medida razoável à situação - pelo credor é adequada, não perigosa e não onerosa, fazendo jus à integral indenização, como pleiteou na sua petição inicial.

Logicamente, o magistrado fará uma retrospectiva dos fatos ocorridos, sendo seus questionamentos voltados a desvendar a correção da conduta do credor. Assim, enquanto o credor deveria cogitar a medida a ser tomada, isto é, uma prospecção, o juiz deve perguntar se a medida foi tomada de acordo com o imposto pela norma de mitigação.

Neste diapasão, o primeiro questionamento a ser feito é se a medida adotada pelo credor foi adequada à situação. Se a resposta for positiva, parte-se para a segunda etapa. Caso a resposta seja negativa, então a medida era inadequada e o magistrado pode estar diante de duas situações: o caso não admitia qualquer medida adequada ou o credor escolheu mal, pois existia medida adequada e ele não a observou. Em ambas as situações a solução é a mesma: o credor só poderá ser indenizado pelos danos inevitáveis ${ }^{329}$.

A segunda etapa também é semelhante à da primeira parte da regra. O magistrado deverá questionar se a medida adotada pelo credor é perigosa e/ou onerosa. Aqui só será o momento de aferição da inevitabilidade do dano ou não, pois independentemente da resposta, se positiva ou negativa, o magistrado deve partir para a terceira etapa. A análise não pode parar neste momento diante de um dano inevitável porque o credor já agiu e tal medida, ainda que onerosa ou perigosa, acarretou consequências para o desfecho da situação. E tais consequências não podem ser ignoradas pelo magistrado, pois afetam diretamente o valor da indenização a ser paga pelo devedor.

\subsubsection{A eficiência como terceira etapa para aferição do quantum indenizatório}

Inaugura-se então a terceira etapa, na qual o magistrado deverá aferir a eficiência da medida adotada pelo credor. Medida eficiente é aquela que atinge o objetivo almejado. Neste diapasão, a eficiência é constatada pelo resultado obtido, ao contrário da adequação,

\footnotetext{
${ }^{328}$ Conforme Capítulo 3, item 3.3. supra.

${ }^{329}$ Vide item 4.3.3 infra.
} 
que é constatada pela formatação do problema em si, isto é, se ainda que haja problemas de periculosidade ou onerosidade, cumpre o papel de mitigar o prejuízo. Se o dano foi mitigado ou evitado, logo a medida tomada foi eficiente.

Não se confunde, igualmente, com a eficiência econômica. A eficiência não é medida pela obtenção de um determinado objetivo pelo menor custo possível ${ }^{330}$ ou se os benefícios superam os custos ${ }^{331}$. Afinal, tais análises já foram realizadas - corretamente ou não, dependendo da apreciação judicial para saber a resposta - quando da superação da etapa da onerosidade da medida adotada. A eficiência da regra de aferição da razoabilidade é puramente a amplitude da mitigação obtida com a medida. Não converge, portanto, com o conceito de eficiência de Pareto ou de Kaldor-Kicks ${ }^{332}$.

Nestes moldes, a medida pode ser total ou parcialmente eficiente, além de ineficiente. Dependendo do que ocorrer, a consequência para a indenização será diversa, assim como será visto ao longo deste capítulo. Dizer que uma medida é parcialmente eficiente ou ineficiente não significa que se está fazendo uma mera comparação com o total dos danos, significando que ela foi eficiente dentro de tudo o que é prejuízo. A eficiência diz respeito a o que a medida adotada pelo credor se propõe a mitigar independentemente do total dos danos. A comparação é feita a partir do dano que se pretende mitigar com aquela medida, uma partícula dentro do todo. $O$ meio empregado deveria ser completamente eficiente para evitar ou minimizar o dano, mas diante de algum equívoco na aplicação da medida pelo credor ela não atingiu o objetivo almejado. Então, se uma medida se propõe a mitigar, por exemplo, um terço do prejuízo, então a análise da eficiência deverá ser realizada dentro deste terço.

Não se deve esquecer que se admite a aplicação de mais de uma medida para a mitigação dos danos, haja vista que cada uma delas poderá incidir em um dano ou aspecto diferente dele. Uma medida pode ser eficiente para mitigar um prejuízo e outra para prejuízo diverso. Ambas completamente adequadas e aptas a cumprir o duty to mitigate the loss. E tudo isto é verificado a partir da regra da aferição da razoabilidade, utilizada em cada uma das medidas separadamente. Isto não se confunde com o grau de eficiência, pois enquanto ele trata da mitigação de um prejuízo específico, a pluralidade de medidas atua

\footnotetext{
${ }^{330}$ COOTER, Robert; ULEN, Thomas. Law \& Economics. $5^{\text {a }}$ ed. Harlow: Pearson Addison-Wesley, 2008. p. 4.

${ }^{331}$ Idem, ibidem. p. 16-18.

${ }^{332} \mathrm{O}$ conceito de eficiência de Pareto diz que a medida é eficiente quando satisfaz as preferências individuais das partes ou a utilidade. Já o conceito de Kaldor-Kicks diz respeito ao valor, o quanto alguém está disposto a pagar por algo e quanto alguém está disposto a receber para abrir mão dela. (Idem, ibidem. p. 17 e 47)
} 
em danos diversos, cada uma com seu respectivo grau de eficiência a ser medido após sua aplicação.

A eficiência de sua medida deve ser total naquilo em que for empregada. Se a eficiência não puder ser total, então a parcela alheia à mitigação é inevitável, não tendo o credor o ônus decorrente do duty to mitigate the loss, salvo se estiver sujeita a outra medida adequada.

Passada esta etapa, passa-se para a seguinte em que se questiona se o credor auferiu lucro com a medida adotada. A análise pormenorizada deste tópico será feita no item seguinte. Adianta-se somente que, caso a resposta seja positiva, deverá haver compensação dos valores obtidos na terceira etapa com os lucros.

Uma última questão a ser discutida é se a regra para aferição da razoabilidade poderia desnaturar a abertura que a cláusula geral da boa-fé concede ao magistrado para a formulação da regra ao caso concreto ${ }^{333}$. Poder-se-ia cogitar que o magistrado ficaria adstrito às balizas da regra e não teria espaço para proferir uma decisão individualizada, específica para o caso em apreço. A assertiva, entretanto, não é verdadeira.

O princípio da boa-fé tem por objetivo último a justiça entre as partes. E a regra da razoabilidade não traz uma resposta definitiva, de conteúdo, mas um caminho a ser seguido para se chegar à solução mais justa para o caso concreto. Isto não impede que o magistrado regulamente outros aspectos da relação jurídica, como a forma de pagamento da indenização, atitudes que partes devem adotar do momento da decisão em diante para a boa continuidade das relações, etc. As etapas aqui desenvolvidas pretendem somente racionalizar o caminho a ser seguido para se chegar a uma decisão, tanto pelo credor, quanto pelo magistrado. Busca tornar o silogismo verdadeiro, alheio aos vícios da discricionariedade exacerbada que pode incidir na apreciação da incidência da norma de mitigação, nos termos apresentados no item anterior. Não há falar, desse modo, em conflito entre a cláusula geral da boa-fé e a regra de aferição da razoabilidade: esta serve de instrumento para a correta aplicação daquela, atendendo unicamente aos ditames do princípio da boa-fé que as fundamenta.

\footnotetext{
${ }^{333}$ Quanto à diferenciação entre cláusula geral, princípio e standard jurídico, ver o Título I, Capítulo 2, item 2.1 .
} 


\subsubsection{Lucros auferidos pelo credor com a mitigação: a quarta etapa}

Com a observância do ônus de mitigação, é possível que a medida eleita pelo credor lhe faça auferir lucros, ou seja, não só cobre os prejuízos que teve com os danos decorrentes do inadimplemento como também traz ganhos além daqueles que teria se a relação jurídica existente com o devedor persistisse nos seus regulares termos. Uma situação que inicialmente parecia ruim, se tornaria vantajosa para o credor, pois conseguiu aumentar seu patrimônio em razão da inadimplência do devedor.

O direito inglês traz interessante exemplo ${ }^{334}$ sobre a incidência de lucro numa relação em que há o duty to mitigate the loss. A British Westinghouse Electric and Manufacturing Co Ltd forneceu à Underground Eletric Railways Co of London Ltd oito turbinas com defeito tanto em seu design quanto na quantidade de carvão que utilizavam. A Underground Eletric Railways Co of London Ltd, mesmo sabendo do problema, aceitou utilizar as turbinas, ainda que se reservasse no direito de se ressarcir dos danos. Passado certo tempo, as turbinas foram substituídas por outras muito mais eficientes que aquelas fornecidas pela British Westinghouse Electric and Manufacturing Co Ltd, mesmo se as que foram originalmente fornecidas estivessem em perfeitas condições, sendo que foram produzidas por outra empresa, a Parsons. A Underground Eletric Railways Co of London $L t d$, então, pleiteou o custo desta substituição e a quantidade de combustível excessiva que teve que utilizar para que as turbinas funcionassem como parte dos danos sofridos.

Na decisão a Corte entendeu que as perdas da Underground Eletric Railways Co of London Ltd deveriam ser ponderadas com os ganhos que obtiveram diretamente dos passos que deram para mitigar os prejuízos. Neste sentido, foi reconhecido o cumprimento do ônus de mitigação do prejuízo pela Underground Eletric Railways Co of London Ltd, mas a eficiência das novas turbinas acabaram por fazê-la economizar nos gastos com combustíveis. Dessa maneira, apesar de não ter obtido o direito de ser ressarcida pelos danos, a Underground Eletric Railways Co of London Ltd foi compensada pelos lucros que obteve.

\footnotetext{
${ }^{334}$ Cf. British Westinghouse Electric and Manufacturing Co Ltd v. Underground Electric Railways Co of London Ltd, 1912, A.C. 673. Visto em MACDONALD, Elizabeth; KOFFMAN, Lawrence. The Law of Contract. $6^{a}$ ed. Oxford: Oxford University Press, 2007. p. 580-584; CHRISTENSEN, W. D.; Sharon. Professional Liability and Property Transactions. Sidnei: The Federation Press, 2004. p. 94-95.
} 
A solução para o ordenamento jurídico pátrio não parece ser diferente. O credor com a sua mitigação conseguiu evitar ou minimizar os prejuízos e foi além: auferiu lucros que não obteria se o devedor não tivesse inadimplido sua obrigação. Por ter conseguido, então, se indenizar pelos ganhos em cima da sua medida mitigadora, é certo que tais valores devem ser descontados da indenização a ser paga pelo devedor. É a busca pelo equilíbrio da relação jurídica: se a solução fosse diferente, o credor seria muito mais beneficiado por lucrar e receber indenização, isto é, receberia duas vezes sobre o mesmo dano.

Neste sentido, assim que estiver definida a eficiência da medida adotada pelo credor na mitigação, deverá ser verificado se este auferiu lucros com a mitigação. No caso de resposta afirmativa, é certo que será necessária a compensação de valores, ou seja, deverá ser subtraído do quantum obtido na terceira etapa o valor do lucro. Este será, finalmente, o valor indenizatório a ser pago pelo devedor ao credor.

\subsection{Análise comparativa dos elementos da regra de aferição da razoabilidade}

Para facilitar o entendimento de como funcionam as etapas de aferição da correta aplicação do duty to mitigate the loss, parte-se agora para a análise pormenorizada de todas as hipóteses de combinação de espécies de medidas. A partir deste modelo hipotético, o magistrado tem uma orientação na aplicação da norma de mitigação, sem que haja indevida interferência na discricionariedade para a criação da regra que regulará as partes, ínsita da cláusula geral da boa-fé. Cria-se, assim, um suporte teórico consistente para evitar a discrepância na apreciação da aplicação da norma de mitigação, reduzindo a possibilidade de tomada de decisões antagônicas.

Além disso, o estudo em hipóteses evita o mero estudo casuístico, o qual se traduz numa mera análise de erro e acerto da jurisprudência, sem que ao menos se desenvolva uma regra geral para orientar a exata aplicação do duty to mitigate the loss. O que seria um tanto quanto contraproducente, haja vista que, pelo que se tem observado, a jurisprudência se mostra bastante vacilante quando o invoca ${ }^{335}$. O objetivo aqui é trazer um arcabouço

\footnotetext{
${ }^{335}$ Vide Capítulo 5, infra, no qual será realizada a aplicação da regra aqui desenvolvida para a identificação da (in)correta aplicação do duty to mitigate the loss na jurisprudência brasileira.
} 
teórico próprio para que, a partir das premissas traçadas, a norma de mitigação seja corretamente aplicada aos casos concretos em que haja sua incidência.

O estudo será dividido da seguinte forma: dentro de cada um dos grupos de medida adequada e inadequada, será subdividido entre combinações de medidas (não) perigosas e/ou (não) onerosas, cada qual como única alternativa de remédio para a mitigação dos prejuízos. Dentro desta subdivisão, será analisada a hipótese de a medida tomada ter sido eficiente ou não, englobando todas as etapas apresentadas alhures acerca da aferição pelo magistrado da correta aplicação da norma de mitigação pelo credor.

\subsubsection{Medida adequada}

\subsubsection{Não perigosa e não onerosa}

Sendo a medida tomada pelo credor adequada, não perigosa e não onerosa, inicialmente o credor cumpriu com o seu ônus de mitigar o prejuízo. Afinal, tomou a medida mais recomendável e que não apresenta qualquer risco tanto para sua vida quanto para o seu patrimônio. No entanto, a aferição completa depende da suficiência de sua atuação, isto é, se mesmo cumprindo todos estes requisitos, conseguiu efetivamente mitigar o prejuízo havido.

Se a medida foi eficiente, não há dúvidas de que a norma de mitigação foi perfeitamente cumprida. $\mathrm{O}$ credor tratou de adotar todas as cautelas e ações necessárias, impedindo ou minimizando os danos. Tudo o que era por ele evitável, foi assim realizado. Portanto, deverá ser este indenizado pelas despesas que incorreu para o cumprimento da norma de mitigação, bem como dos prejuízos inevitáveis que sofreu.

Sendo a medida ineficiente, o quantum indenizatório não poderá ser o mesmo. $\mathrm{O}$ credor tinha o poder de mitigar ou evitar o dano e, mesmo assim, não o fez. Tomou a medida correta para o caso, mas não na extensão que lhe incumbia. A situação aqui é diversa daquela em que ocorreu uma circunstância alheia à sua vontade ${ }^{336}$ que o impediu de minimizar o prejuízo: o credor, voluntariamente, deixou de mitigar o dano - evitável por completo, por razões que escapam da relevância para a análise da aplicação da norma de mitigação.

\footnotetext{
${ }^{336}$ A ser estudada no item 4.6. infra.
} 
Neste sentido, o credor só será indenizado na extensão de sua atuação, isto é, nos gastos que efetivamente evitaram ou mitigaram os prejuízos, excluídos os danos evitáveis que não foram objeto de mitigação pelo credor. Além disso, será indenizado também pelos danos inevitáveis, já que a estes o duty to mitigate the loss não se aplica.

\subsubsection{Perigosa e não onerosa}

Na hipótese de o credor adotar medida adequada, perigosa e não onerosa, é preciso compreender inicialmente que houve atuação sem ao menos a norma de mitigação assim impor. Isto porque o duty to mitigate the loss não dispõe que o credor tem o ônus de agir se a medida, ainda que adequada e não onerosa, possa lhe trazer algum perigo para sua vida. Neste diapasão, o credor agiu por uma faculdade jurídica, arriscando-se para mitigar um prejuízo concebido como inevitável, o qual cabe ao devedor indenizar.

Mesmo assim, a conduta do credor não pode ser ignorada. O risco pelo qual passou para evitar o agravamento do dano é relevante para a verificação do caso e, por isso, influi diretamente na estimação do quantum indenizatório. Ainda que seja uma faculdade, acarreta consequências jurídicas para o devedor, já que os danos que causou pelo seu inadimplemento foram objeto de mitigação pelo credor, o qual incorreu em despesas para sua realização.

Portanto, sendo sua atuação eficiente para a mitigação do prejuízo, o devedor deverá indenizá-lo pelas despesas incorridas, bem como pelos demais danos inevitáveis, se houver. Não há alternativa: o credor se arriscou e teve sucesso em evitar ou minimizar os danos. Logo, o que gastou deve ser objeto de ressarcimento.

Já na situação de a medida ser ineficiente, é preciso cuidado na apreciação do caso concreto. Tendo a medida reduzida eficiência, o devedor deverá indenizar o credor pelos danos inevitáveis que não foram objeto de atuação do credor e pelas despesas que este incorreu para, com sucesso, evitar ou minimizar, ainda que conceitualmente inevitáveis. Importante ressaltar que neste caso não se está diante do uso de medida onerosa, isto é, as despesas com a medida adequada e perigosa não são desarrazoáveis em razão de sua onerosidade $^{337}$. Dessa maneira, cabe a indenização.

\footnotetext{
${ }^{337}$ Consoante será visto no item 4.3.1.4. infra.
} 
Na hipótese de ineficiência total, todavia, o credor só deverá ser indenizado pelos danos inevitáveis ocorridos, excluindo qualquer despesa havida com a tentativa de mitigação. Consoante dito, o credor exerceu in casu uma faculdade jurídica e não o ônus da mitigação. Não cabia a ele agir, pois corria o risco de ceifar sua própria vida ou prejudicar sua integridade física. Tendo em vista que assumiu este risco, é preciso que pelo menos tenha havido alguma influência na relação jurídica existente com o devedor. Só que, ao contrário disso, nada aconteceu: o dano inevitável não foi evitado, tampouco minimizado.

Foi um risco que o credor assumir correr, o qual o princípio da boa-fé não impõe como norma de conduta, sobretudo através do duty to mitigate the loss. Ora, se o credor não tinha nem ao menos um ônus, não se mostra compatível com a ordem jurídica compelir o devedor a indenizar uma iniciativa desarrazoada do credor, a qual em nada interfere no desdobramento fático.

Inclusive, analisado sobre outro ponto de vista, obrigar o devedor a indenizar o credor nesta hipótese é incentivar este último a adotar medidas perigosas para que haja um acréscimo na sua indenização. Compelindo o devedor a indenizar, o credor receberia tanto pelos prejuízos inevitáveis quanto pelas despesas havidas na tentativa sem sucesso de mitigar. Numa situação como esta, o credor poderia ponderar ser interessante arriscar-se a agir perigosamente, já que, em qualquer resultado - tendo sucesso ou não na mitigação será indenizado pelo devedor. Trata-se de postura, contudo, inadmissível, pois nitidamente contrária ao princípio da boa-fé. O credor tomará medida já com o intuito de prejudicar a situação do devedor, de total má-fé, pouco se importando em reduzir os desgastes que a inadimplência já causou.

Por isso, na hipótese de ineficiência, é preciso se atentar à sua extensão. Sendo a ineficiência parcial, o devedor tem que indenizar pelos danos inevitáveis e os gastos do credor com a mitigação; sendo a ineficiência total, o devedor só indeniza pelos danos inevitáveis.

\subsubsection{Não perigosa e onerosa}

A atuação do credor ao adotar uma medida adequada, não perigosa, porém, onerosa, é alheia ao duty to mitigate the loss, tendo em vista que este não impõe o ônus de 
mitigação no caso de a medida violar o patrimônio (ainda que moral) do credor. Sendo uma medida onerosa, o dano é, conceitualmente, inevitável. Dessa forma, assim como na adoção de uma medida adequada, mas perigosa, a medida onerosa se revela como uma mera faculdade do credor, que decidiu agir mesmo não sendo necessário.

No caso de ineficiência total da medida tomada, o credor não será indenizado dos gastos que teve com tentativa de mitigar os prejuízos. Da mesma maneira que ocorre no caso de total ineficiência da medida perigosa, o comportamento do credor em nada influiu na relação jurídica existente com o devedor. Logo, não existe razão para indenizar por aquilo que o credor fez sem medir as inócuas consequências. Mais ainda, indenizar em situações como essas seria um incentivo ao credor a agir de má-fé, pois qualquer medida adequada e onerosa no fim será objeto de indenização pelo devedor. Portanto, só será indenizado pelos danos inevitáveis.

Já no caso de eficiência total ou parcial, a solução é diferente. É certo que, apesar de o credor ter se utilizado de medida equívoca, o prejuízo foi evitado ou minimizado. Ele não possuía o ônus de mitigar - pelo menos não pela via eleita -, mas mesmo assim o fez. Por isso, se por um lado é injusto fazer com que o devedor arque com despesas exageradas, também o é se o credor tiver que assumir todos os gastos, sendo que teve sucesso, ainda que parcial, em mitigar o dano. Como ambas as partes possuem uma participação no prejuízo - o devedor pelo seu inadimplemento e o credor pela sua medida onerosa -, não parece a melhor solução haver punição para somente uma delas.

Neste sentido, o credor deverá ser indenizado não só pelos prejuízos inevitáveis que não foram objeto da mitigação com sucesso, mas também pelas despesas que incorreu. Só que esta última com a limitação do valor do dano mitigado. Ou seja: o credor é indenizado pela despesa, mas até o limite que se liquida do dano que foi efetivamente evitado ou minimizado.

A limitação pelo dano efetivamente mitigado é resultado do exercício do ônus processual do devedor. Ele é quem deve alegar em sua defesa que a medida foi onerosa, isto é, seu valor ultrapassa aquele do prejuízo objeto de mitigação. Só dessa maneira pode pleitear a redução no quantum indenizatório. Assim, o magistrado definirá as responsabilidades e liquidará o valor da indenização no limite do valor do dano mitigado. Sua indenização, portanto, é composta pelo valor dos danos inevitáveis somados com o valor-limite dos danos efetivamente mitigados. 
Esta verificação, inclusive, está inserida como consequência natural do pressuposto de exigibilidade processual tratado alhures ${ }^{338}$. A defesa contra o pedido de perdas e danos pelo credor na ação indenizatória é o único momento em que o devedor pode questionar o cumprimento da norma de mitigação, isto é, se os prejuízos que o credor tenta a ele imputar são realmente de sua responsabilidade. A partir do confronto das alegações, o julgador poderá estipular, conforme a cláusula geral da boa-fé e as etapas de aferição da razoabilidade, a regra para o caso concreto.

\subsubsection{Perigosa e onerosa}

A hipótese em que o credor adota uma medida adequada, porém perigosa e onerosa, é mais uma em que agiu sem a norma de mitigação lhe atribuir este ônus. Novamente, não lhe cabia tomar esta medida, haja vista que pôs em risco tanto sua vida quanto seu patrimônio por danos que são conceitualmente inevitáveis. A atuação é uma mera faculdade, a qual atrairá consequências conforme a sua eficiência.

No caso da ineficiência total, a solução não se difere das hipóteses em que a medida é somente perigosa ou onerosa: o credor deverá ser indenizado apenas pelos danos inevitáveis. Afinal, seu comportamento não teve qualquer influência na relação jurídica existente com o devedor. A indenização pelas despesas da ineficiente mitigação serviria como incentivo à má-fé, pois o risco do credor serviria de incremento para o quantum indenizatório.

Já nos casos da eficiência total ou parcial, a solução tem que ser semelhante à dos casos em que a medida é somente onerosa. Embora o credor tenha se arriscado, ficando exposto a um perigo, a onerosidade impede que o ressarcimento seja completo, sob o risco de transformar a conduta em fonte de enriquecimento ilícito. $\mathrm{O}$ credor não pode se valer desnecessariamente de medidas onerosas para depois buscar indenização do devedor. Ambos, portanto, deram a sua contribuição para a criação ou incremento do prejuízo.

O princípio da boa-fé impõe os deveres de cooperação e lealdade e, por consequência, acaba por limitar o valor da indenização a ser recebida. E o limite é o valor do dano efetivamente mitigado. Então, se o credor conseguiu mitigar completa ou

\footnotetext{
${ }^{338}$ Vide Título II, Capítulo 3, item 3.3. supra.
} 
parcialmente, o valor pelo qual será indenizado é dos prejuízos inevitáveis - se houver, além da medida tomada - somado com o valor do prejuízo mitigado.

\subsubsection{Coexistência de medidas adequadas}

Podem ocorrer situações que não existe somente uma medida adequada, mas diversas que o credor pode optar por adotar. A diferença aqui para as hipóteses anteriormente apresentadas nos itens anteriores é que o credor escolheu mal qual medida adotar, pois possuía mais de uma. Tomou justamente aquela que lhe oferece perigo e/ou viola seu patrimônio, não sopesando corretamente sobre os riscos que poderia incorrer. Assim, não adotou a medida adequada, porém perigosa e/ou onerosa porque não tinha outra opção - ainda que a norma de mitigação não lhe obrigasse a agir desse modo -, mas porque optou de maneira equívoca.

Dentre as hipóteses mencionadas alhures, apenas haverá diferença nas consequências quando se está diante de uma medida onerosa, ainda que esteja em conjunto com uma medida perigosa. Isto porque, independentemente de a medida ser isoladamente perigosa ou perigosa e onerosa ao mesmo tempo, caso ela apresente algum resultado eficiente, a indenização será pelos danos inevitáveis somados com as despesas havidas ${ }^{339}$.

Assim, diante da adoção de uma medida onerosa na coexistência de uma que não apresenta este gravame, o credor deverá ser indenizado não só pelos prejuízos inevitáveis que não foram objeto da mitigação com sucesso, mas também pelas despesas que incorreu. Só que esta última com a limitação do valor da medida adequada que não seria onerosa se aplicada à hipótese. Ou seja: o credor é indenizado pela despesa, mas até o limite que gastaria se tivesse adotado a medida adequada e não onerosa aplicável.

Por exemplo: existe uma medida adequada com custo de cem reais e outra de trezentos reais. O credor, ao invés de optar pela primeira, seleciona a segunda opção, seja por imaginar ser um meio de punir o devedor pelo inadimplemento com o pedido de indenização posterior, seja por mera negligência ou imprudência. Tendo sucesso na mitigação, se buscar o ressarcimento posterior, sua indenização será limitada aos danos inevitáveis que efetivamente ocorreram e de cem reais pelas despesas havidas, e não

${ }^{339}$ Vide item 4.3.1.2. supra. 
trezentos reais. Afinal, adotou medida onerosa, não podendo nessa hipótese o devedor ser prejudicado pela má escolha do credor.

O resultado, contudo, é um pouco diferente quando a medida adotada não tem a eficiência esperada, ficando abaixo da despesa realizada. Neste caso, o valor da indenização não será limitado ao valor da medida adequada e que não é onerosa, mas ao valor do dano efetivamente mitigado, ou seja, conforme o grau de eficiência da medida. A solução deve ser diferente porque o credor não pode receber indenização cheia por uma medida que, no fim, se mostrou ineficiente por sua culpa, já que tinha o potencial de ser eficiente. Significa que o credor, mesmo tomando a medida adequada e, a princípio, ausente de onerosidade, tornou-a posteriormente onerosa pelo sua baixa eficiência. A norma de mitigação, então, não pode tolerar este desempenho ruim, devendo reequilibrar a situação das partes.

A comparação entre a onerosidade das medidas poderia ser tormentosa se pensada unicamente pelo lado do credor. Não seria ele que apresentaria esta informação, senão daria argumentos para haver redução no quantum indenizatório pleiteado. Neste diapasão, quem tem o dever de mostrar que existia medida menos onerosa é do devedor, réu na ação indenizatória. Em sua defesa, deverá demonstrar que o credor não optou pela melhor medida, já que, apesar de adequada a mitigar o dano, é mais onerosa que outra. Desse modo, o magistrado irá apreciar a adequação, onerosidade, perigo e eficiência das medidas para estipular o valor da indenização.

Esta é consequência natural do pressuposto de exigibilidade processual tratado alhures $^{340}$. O momento em que o devedor pode questionar o cumprimento da norma de mitigação é na defesa processual contra o pedido de perdas e danos pelo credor na ação indenizatória. Só a partir disso é que o juiz poderá aferir a responsabilidade de cada um e, principalmente, verificar o cumprimento da norma de mitigação, se incidente no caso.

\subsubsection{Medida inadequada}

Estando diante de uma medida inadequada, nunca surgirá para o devedor a obrigação de indenizar o credor, devendo este arcar com todos os prejuízos decorrentes dos

\footnotetext{
${ }^{340}$ Vide Título II, Capítulo 3, item 3.3. supra.
} 
danos evitáveis e das despesas que incorreu com a medida adotada. Uma medida inadequada não fomenta o fim almejado, isto é, não é uma medida que chega ao menos parecer ser recomendável de ser aplicada diante da iminência ou ocorrência do prejuízo ${ }^{341}$. É o equívoco na origem, já que nem ao menos chega ao ponto de analisar a onerosidade ou periculosidade da situação.

Por razões lógicas, uma medida inadequada também não chega ao ponto de ter sua eficiência mensurada, até porque nunca será eficiente. Se nem ao menos se enquadra como uma solução viável para evitar ou minimizar um prejuízo, não tem como ser ainda que minimamente eficiente.

Assim, se o credor exige indenização por uma medida inadequada, estará agindo de má-fé, já que é de seu conhecimento que a medida não se relaciona nem um pouco com a relação jurídica existente com o devedor. Estará nitidamente tentando transferir ao devedor um débito próprio, buscando puni-lo pelo seu inadimplemento com questões que em nada se relacionam ao conflito existente. A única indenização a que tem direito é quanto aos prejuízos ditos inevitáveis, ou seja, os quais a norma de mitigação não lhe impõe o ônus de evitar ou minimizar, pois nestes casos a medida lhe acarretaria um perigo ou uma onerosidade além daquela possível de suportar diante dos ditames do princípio da boa-fé.

\subsection{Medida razoável e prejuízo indeterminado}

Questão tormentosa é definir como que o credor poderá tomar uma medida dita razoável para mitigar o prejuízo sem poder apurar o seu valor. São casos em que os objetos do patrimônio do credor são tão especiais que a mensuração das perdas e danos se torna uma tarefa hercúlea, quiçá impossível de se chegar a um valor exato. É o caso, por exemplo, de um incêndio em uma biblioteca cheia de livros raros, causando a destruição parcial de várias obras. $\mathrm{O}$ credor poderia fazer a restauração delas, se esforçar e adquirir outros exemplares ou nada fazer, cobrando a indenização total do devedor causador do prejuízo. A dificuldade consiste, então, na aplicação da regra de aferição da razoabilidade sem um valor exato do prejuízo, com o risco de o credor adotar uma medida onerosa.

${ }^{341}$ Vide item 4.2.1. supra. 
A primeira atitude a ser feita pelo credor é, indubitavelmente, verificar quais prejuízos não são passíveis de serem mitigados por uma medida razoável, já que todas as disponíveis se mostram inadequadas. Por serem as medidas inadequadas, o dano é inevitável, já que elas nem ao menos fomentam o fim almejado, isto é, a mitigação do prejuízo. Logo, não recai sobre o credor qualquer ônus de mitigação.

Passada esta etapa, o credor estará diante daqueles danos que, ainda que em tese, poderão ser evitados ou minimizados, já que existe pelo menos uma medida adequada que poderá ser adotada. Cabe agora desvendar se a medida é perigosa e/ou onerosa.

A periculosidade é facilmente identificada pelo credor, já que dadas as suas condições físicas e mentais, torna-se possível saber se a medida trará um risco para sua vida. Se a resposta for afirmativa, logo a medida não é razoável e o dano, por conseguinte, inevitável.

A onerosidade só poderá, em um caso de valor de prejuízo indeterminado, ser apreciada por meio de uma estimativa. O credor não possui outra solução, haja vista que é impossível alcançar um valor exato para o seu prejuízo. E esta estimativa servirá de parâmetro para a aferição da onerosidade da medida a ser tomada (ou não) para mitigar o dano.

Questionar-se-ia como o credor faria tal estimativa, e a resposta se encontra na própria noção de razoabilidade há anos desenvolvida pela doutrina e jurisprudência, tanto pátria quanto estrangeira. O credor deverá se valer da natureza e a finalidade do que está sendo feito, das circunstâncias do caso e de quaisquer usos e práticas de comércio ou profissões envolvidas, se for o caso ${ }^{342}$. Ninguém melhor que ele - e/ou um perito, se necessário - para estimar as perdas e danos sobre a sua própria atividade. O valor estimado pode ser inexato, mas é suficiente para ao menos desvendar se compensa mitigar ou não o prejuízo $^{343}$.

Retornando ao exemplo da biblioteca. O proprietário da biblioteca terá que fazer uma estimativa do prejuízo sofrido, alcançando um valor que, a princípio, engloba todas as perdas e danos. Em seguida, avaliará as medidas adequadas que tem disponível para saber se são perigosas ou onerosas. A restauração dos livros parcialmente destruídos e a

\footnotetext{
${ }^{342}$ Este conceito de razoabilidade é encontrado tanto no artigo $5^{\circ}$ da Common European Sales Law quanto do artigo 1:302 da Principles of European Contract Law. Ambos os diplomas serão analisados no Título III, Capítulo 7, infra.

${ }^{343} \mathrm{O}$ devedor pode até entender que o valor estimado é excessivo, mas isto é matéria a ser discutida e provada em outro momento, qual seja, na segunda parte da regra de aferição da razoabilidade.
} 
aquisição de novos exemplares não se mostram medidas perigosas. Assim, não há problemas quanto ao filtro da periculosidade.

No tocante a onerosidade, o prejudicado terá que confrontar o valor dos prejuízos com o da restauração e da aquisição dos novos exemplares. Se o valor das medidas ultrapassar o valor estimado do prejuízo, o credor está liberado de ter que mitigar o dano, pois na ocorrência de uma medida onerosa não incide o duty to mitigate the loss. Poderá, então, cobrar integralmente a indenização do causador do prejuízo. Por outro lado, se o valor das medidas seja menor que o valor estimado do dano, incidirá a norma de mitigação, e o credor terá que se valer delas. Cobrará, posteriormente, apenas os gastos que teve com as medidas razoáveis de mitigação.

Assim, verifica-se que mesmo numa hipótese de prejuízo indeterminado a regra de aferição da razoabilidade é aplicável. A mudança ocorre apenas na atividade que o credor terá que realizar para se chegar a um valor do prejuízo: estimado conforme as condições de razoabilidade largamente conhecidas e há muito aplicadas indistintamente, sem balizas para uma aplicação mais uniforme, consoante se propõe neste estudo com a regra de aferição da razoabilidade.

\subsection{Consequências da inobservância do ônus de mitigação}

Na hipótese de descumprimento do duty to mitigate the loss, isto é, caso o credor não adote qualquer medida para mitigar seu prejuízo, não terá direito à indenização pelos danos considerados evitáveis. Afinal, eram danos que o próprio credor poderia ter minimizado ou evitado. Logo, nada mais justo, à luz do princípio da boa-fé, que este não tenha qualquer proveito da sua postura irregular. Tal situação, inclusive, ficou nítida nos exemplos apresentados no item anterior.

A única situação em que o credor teria direito à indenização é se, além dos danos evitáveis, também existirem aqueles considerados inevitáveis. Quanto a estes últimos, o credor realmente não tem a incumbência de agir, haja vista que pode incorrer em algum perigo ou onerosidade indevida. Assim, como a norma de mitigação não lhe incumbe do ônus de mitigar, deverá ser indenizado pelos danos, já que são de responsabilidade do devedor. 
Portanto, pode-se dizer que a consequência jurídica da inobservância do ônus de mitigação é semelhante àquela em que o credor adota medida inadequada. No entanto, neste último caso a má-fé é muito mais nítida, pois é com plena consciência que a medida em nada influiu na mitigação do prejuízo que o credor busca a indevida indenização. Ao menos quando o credor deixa simplesmente de mitigar, pode ainda haver a sincera crença de que todos os danos são de responsabilidade do devedor. Até porque acredita que todos são decorrentes de seu inadimplemento, inevitáveis. A diferença de ambos os casos está, portanto, na existência ou até mesmo na própria intensidade da má-fé, a depender da consciência do credor no caso da inobservância do ônus de mitigar: se sabe que possuía o ônus, a diferença está na intensidade; se não sabe, está na existência.

\subsection{Caso fortuito, força maior e fato de terceiro}

Além de a própria relação jurídica, por si só, não trazer o resultado esperado, também há o risco de outras circunstâncias interferirem, forçando a inadimplência ou agravamento do dano sem que haja culpa das partes. São os chamados casos fortuitos, de força maior e os fatos de terceiro: situações que os efeitos são necessários e inevitáveis, pois alheios à vontade das partes.

O caso fortuito é caracterizado por um ato ou fato alheio à vontade das partes, derivado de uma conduta humana, como é o caso de uma greve ou de uma guerra. A força maior, por sua vez, advém de uma condição natural, impossível de impedir, como um terremoto, inundação ou raio ${ }^{344}$. Embora exista esta diferença conceitual na doutrina, o parágrafo único do artigo 393 do Código Civil não os distingue, apenas evidenciando a inevitabilidade de seus efeitos. Afinal, apesar de interessante, não é um critério necessário para a configuração tanto de um quanto de outro, já que os requisitos são os mesmos.

Para a configuração do caso fortuito ou da força maior, portanto, é preciso que ocorra uma situação sem qualquer culpa da parte, que resulte na impossibilidade total do cumprimento de sua obrigação. Aliás, um requisito é decorrência do outro: se o acontecimento é irresistível, logo não há falar em existência de culpa, senão não é caso

${ }^{344}$ GONÇALVES, Carlos Roberto. Responsabilidade civil. $11^{\mathrm{a}}$ ed. São Paulo: Saraiva, 2009. p. 826. 
fortuito ou de força maior; se a parte é culpada pela ocorrência, então não é um fortuito ou força maior, mas determinado pela sua conduta ilícita ${ }^{345}$.

Também é preciso que o acontecimento seja superveniente, já que deve ser uma situação que obsta o cumprimento da obrigação. É uma decorrência lógica: se tivesse ocorrido antes, não teria como dizer que houve quebra do nexo de causalidade, pois ele nem mesmo existiria para ser rompido. $\mathrm{O}$ caso fortuito e a força maior, portanto, devem cortar a relação entre o ato do agente e o dano da vítima.

Por fim, o fato deve ser inevitável ou irresistível. Aqui é preciso realizar uma diferenciação do conceito de inevitabilidade das circunstâncias alheias daquele trabalhado neste estudo até o momento. A inevitabilidade na norma de mitigação é a alternativa decorrente da falta de necessidade de o credor agir quando ocorre prejuízo, tendo em vista que sua atuação acarretará riscos para sua vida ou patrimônio. A inevitabilidade do caso fortuito e da força maior, por sua vez, é a total impossibilidade de evitar o prejuízo, já que está totalmente fora do controle do agente. Então, enquanto que na norma de mitigação a inevitabilidade decorre de um risco, suspendendo o ônus do credor de tentar eliminar ou diminuir o dano, no caso fortuito e na força maior a inevitabilidade decorre da inexistência de qualquer medida possível para evitar o prejuízo.

Ambas as acepções, contudo, são conciliáveis. Enquanto o duty to mitigate the loss define que certo dano é inevitável e, por isso, o credor deve ser indenizado, pois não pode se arriscar a mitigá-lo, este também pode ser inevitável em razão do caso fortuito, já que não só o credor não pode se arriscar como nem tem meios para tanto. Por isso, ambos os conceitos de inevitabilidade atuam em diferentes frentes, tendo por denominador comum somente a expressão "inevitabilidade”.

Feitas tais considerações, é o momento de definir quais as consequências jurídicas da influência do caso fortuito e da força maior na norma de mitigação. Para tanto, é preciso separar duas hipóteses: a primeira em que o caso fortuito ou a força maior fazem com que o devedor se torne inadimplente e a segunda em que fazem com que o credor fique impedido de exercer o seu ônus de mitigar.

A primeira hipótese é a clássica, já que a inadimplência decorre da causa excludente de responsabilidade. $\mathrm{O}$ devedor fica impedido de cumprir sua obrigação em razão de causa superveniente irresistível. Em razão de sua ausência de culpa, não poderá

\footnotetext{
${ }^{345}$ Idem, ibidem. p. 827.
} 
ser responsabilizado pelos danos que do caso fortuito ou da força maior decorrerem. Consequentemente, os prejuízos que o credor tiver não estão sujeitos à indenização, pouco importando para ele cumprir ou não a norma de mitigação. Ou seja: o pressuposto de existência de haver um prejuízo imputável ao devedor deixou de existir. A sua análise será puramente econômica: só mitigará os danos se compensar financeiramente, já que não poderá exigir do devedor indenização por eles.

Já na segunda hipótese, o devedor culposamente se tornou inadimplente e os prejuízos causados por ele são evitáveis pelo credor. Decidindo por tomar a medida que entende mais adequada - sem perigo ou onerosidade -, é frustrado por um caso fortuito ou de força maior. A resolução aqui é diferente da primeira hipótese, pois o devedor terá que arcar com o prejuízo do credor. Isto porque o prejuízo que era evitável se tornou inevitável por conta do acontecimento fortuito ou de força maior. $\mathrm{O}$ credor, antes, poderia agir sem que incorresse em qualquer risco. No entanto, a ocorrência irresistível tornou impossível a adoção de qualquer medida, transformando aquilo que era evitável em inevitável. Como nisto o credor não teve culpa alguma, não pode ser punido por uma dita violação à norma de mitigação. Assim, deverá o devedor arcar com os prejuízos do credor: os danos inevitáveis e despesas que tenha realizado antes de os danos se tornarem inevitáveis.

Interessante também o caso de o credor resolver tomar medida adequada, mas perigosa e/ou onerosa e no fim ser impedido pelo caso fortuito ou de força maior. O credor não tinha o ônus de mitigar, mas, mesmo assim, tinha a intenção de assim fazê-lo. A consequência aqui é a mesma vista pelo filtro da eficiência nos casos trazidos nos itens anteriores $^{346}$. Sendo a medida inadequada, a resposta é a mesma também já trazida no item pertinente ${ }^{347}$.

Prejuízos também podem ser causados verdadeiramente por terceiros, apesar de o agente ser o causador direto. É o caso do infortúnio atropelamento em razão de acidente automobilístico, em que o agente causa o prejuízo, mas só porque o condutor do outro veículo o obrigou a tanto por sua conduta ilícita. Um veículo empurra o outro em direção ao pedestre, causando o atropelamento.

Situações como estas estão reguladas pelos artigos 929 e 930 do Código Civil. A vítima do dano poderá propor ação indenizatória tanto contra o agente direto quanto o terceiro, sendo que aquele poderá propor ação regressiva contra este para reaver os valores

\footnotetext{
${ }^{346}$ Vide itens 4.3.1.2, 4.3.1.3, 4.3.1.4 e 4.3.2 supra.

${ }^{347}$ Vide item 4.3.3. supra.
} 
despendidos com o ressarcimento. Dessa maneira, mesmo que o autor do dano esteja acobertado pelo estado de necessidade, terá que indenizar a vítima, restando-lhe apenas exercer seu direito de regresso contra o terceiro ${ }^{348}$. No entanto, estas situações devem ser distinguidas daquelas em que a culpa é exclusivamente de terceiro, pois estes casos se assemelham ao do caso fortuito, tendo, portanto, as mesmas consequências estudadas anteriormente $^{349}$.

Neste sentido, sendo previsível a ocorrência do prejuízo por fato de terceiro, isto é, assumindo o agente o risco de produzi-lo com sua atividade lícita, ele também será responsável por indenizar a vítima. A partir desses termos, o fato de terceiro não modifica a responsabilidade da parte, a qual ainda terá que indenizar a outra pelos prejuízos surgidos. Por isso, transportando para a hipótese do duty to mitigate the loss, o credor ainda terá que evitar ou minimizar o dano, tendo ação regressiva contra o terceiro que participou da conduta contrária à norma de mitigação. $\mathrm{O}$ fato de terceiro, neste escopo, em nada modifica a responsabilidade das partes: se o prejuízo era evitável, deste ônus ele não se desincumbiu, não adquirindo o direito de ser indenizado.

\subsection{Exemplos hipotéticos}

Para uma melhor compreensão do funcionamento dos filtros de razoabilidade a serem aplicados pelo juiz na resolução do caso concreto, trazemos exemplos desenvolvidos por nós em que se verifica o quantum indenizatório quando adotadas medidas em combinação com as mais diversas variáveis, demonstradas por hipóteses $\left(\mathrm{H}_{1}, \mathrm{H}_{2}\right.$, etc.). Pretende-se, portanto, demonstrar a viabilidade da teoria aqui desenvolvida para a razoabilidade da atuação do credor frente o duty to mitigate the loss.

Referidos exemplos foram inspirados principalmente pela Teoria dos Jogos, a qual trabalha com as diversas opções disponíveis para determinado indivíduo dadas as circunstâncias em que se encontra, devendo decidir por uma estratégia dependendo da

\footnotetext{
${ }^{348}$ GONÇALVES, Carlos Roberto. Responsabilidade civil. 11 a ed. São Paulo: Saraiva, 2009. p. 811.

349 "Quando, no entanto, o ato de terceiro é a causa exclusiva do prejuízo, desaparece a relação de causalidade entre a ação ou a omissão do agente e o dano. A exclusão da responsabilidade e dará porque o fato de terceiro se reveste de características semelhantes às do caso fortuito, sendo imprevisível e inevitável. Melhor dizendo, somente quando o fato de terceiro se revestir dessas características e, portanto, equiparar-se ao caso fortuito ou à força maior, é que poderá ser excluída a responsabilidade do causador direto do dano". (Idem, ibidem. p. 811-812)
} 
postura de outro indivíduo ${ }^{350}$. No entanto, a análise foi adaptada para a apresentação mais didática do funcionamento da regra de aferição da razoabilidade e em conformidade com os seus elementos desenvolvidos ao longo deste capítulo.

\subsubsection{Exemplo 1: medidas com eficiência total}

O dano a ser sofrido é estipulado em 200. Pode existir a Medida 1, na qual o credor gastaria 100, que não é onerosa. O credor optou pela Medida 2, na qual gasta 300, ou seja, é onerosa pois de valor maior que o dano. Em ambas as medidas adequadas, a eficiência é total. Nestes termos, a indenização ficará da seguinte forma, dependendo do que for feito:

\begin{tabular}{|c|c|c|c|c|}
\cline { 2 - 5 } \multicolumn{1}{c|}{} & Dano & Medida 1 & Medida 2 & Indenização \\
\hline $\mathrm{H}_{1}$ & 200 & 100 & 300 & 100 \\
\hline $\mathrm{H}_{2}$ & 200 & Não existe & 300 & 200 \\
\hline $\mathrm{H}_{3}$ & 200 & Não existe & Não adota & 200 \\
\hline $\mathrm{H}_{4}$ & 200 & Não adota & Não adota & 0 \\
\hline
\end{tabular}

$\mathrm{H}_{1}$ : Coexistência de medida não onerosa e onerosa, sendo que o credor opta pela onerosa. A indenização é limitada ao valor da Medida 1;

$\mathrm{H}_{2}$ : Existência apenas de medida onerosa, adotada pelo credor. A indenização é limitada ao valor do dano efetivamente mitigado;

$\mathrm{H}_{3}$ : Inexistindo medida adequada e que não seja onerosa, o credor não adota nenhuma medida. A indenização é limitada ao valor do dano sofrido;

$\mathrm{H}_{4}$ : Existindo medida adequada e que não seja onerosa, o credor não a adota, nem ao menos a onerosa. Não há indenização em razão da inércia do credor.

Solução:

${ }_{350}$ COOTER, Robert; ULEN, Thomas. Law \& Economics. $5^{\text {a }}$ ed. Harlow: Pearson Addison-Wesley, 2008. p. 38. 
a) Havendo coexistência de medidas adequadas, sendo que uma delas não é onerosa, o credor sofre maior pena em sua indenização, já que poderia ter optado de maneira a não agravar ainda mais a sua situação, exigindo valores além do dano mitigado;

b) Não havendo a alternativa de medida adequada que não é onerosa, e mesmo assim o credor agiu, será ressarcido no valor do dano mitigado, já que não lhe cabia agir neste caso e a indenização total fomentaria o enriquecimento ilícito;

c) Não havendo qualquer conduta do credor, isto é, não mitigando o dano pois o duty to mitigate the loss assim não lhe impõe este ônus, o credor será ressarcido dos danos sofridos, haja vista que são inevitáveis;

d) Caso o credor não adote a Medida 1, quando existente, que não é onerosa, não terá direito à indenização, pois os danos seriam na verdade evitáveis;

e) Em todos os casos o credor não se beneficia de sua atuação irregular. No primeiro caso, inclusive, é prejudicado, pois agiu em descompasso com a boa-fé ao adotar medida mais onerosa. Neste sentido, não havendo vantagem em qualquer situação - e até sendo equiparada caso atue ou não no caso de existir só uma medida onerosa cabível resta-lhe obedecer aos termos traçados neste estudo da norma de mitigação, isto é, agir apenas quando a medida for adequada e não ser onerosa.

\subsubsection{Exemplo 2: medida adequada com valor equivalente ao dano}

O dano a ser sofrido é estipulado em 100. Pode existir a Medida 1, na qual o credor gastaria 100, que não é onerosa. O credor optou pela Medida 2, na qual gasta 200, ou seja, é onerosa pois de valor maior que o dano. Em ambas as medidas adequadas, a eficiência é total. Nestes termos, a indenização ficará da seguinte forma, dependendo do que for feito:

\begin{tabular}{|c|c|c|c|c|}
\cline { 2 - 5 } \multicolumn{1}{c|}{} & Dano & Medida 1 & Medida 2 & Indenização \\
\hline $\mathrm{H}_{1}$ & 100 & 100 & 200 & 100 \\
\hline $\mathrm{H}_{2}$ & 100 & Não existe & 200 & 100 \\
\hline $\mathrm{H}_{3}$ & 100 & Não existe & Não adota & 100 \\
\hline
\end{tabular}




\begin{tabular}{|l|l|l|l|l|}
\hline $\mathrm{H}_{4}$ & 100 & Não adota & Não adota & 0 \\
\hline
\end{tabular}

$\mathrm{H}_{1}$ : Coexistência de medida não onerosa e onerosa, sendo que o credor opta pela onerosa. A indenização é limitada ao valor da Medida 1;

$\mathrm{H}_{2}$ : Existência apenas de medida onerosa, adotada pelo credor. A indenização é limitada ao valor do dano efetivamente mitigado;

$\mathrm{H}_{3}$ : Inexistindo medida adequada e que não seja onerosa, o credor não adota nenhuma medida. A indenização é limitada ao valor do dano sofrido;

$\mathrm{H}_{4}$ : Existindo medida adequada e que não seja onerosa, o credor não a adota, nem ao menos a onerosa. Não há indenização em razão da inércia do credor.

Solução:

a) Assim como ocorreu no Exemplo 1, o credor não se beneficia de sua atuação irregular, mesmo que o valor do dano e da medida adequada e que não é onerosa sejam iguais. Assim, novamente, o critério atende à norma de mitigação.

\subsubsection{Exemplo 3: medidas com eficiência menor que o dano, mas maior que a medida adequada e não onerosa}

O dano a ser sofrido é estipulado em 200. Pode existir a Medida 1, na qual o credor gastaria 100, que não é onerosa. O credor optou pela Medida 2, na qual gasta 300, ou seja, é onerosa pois de valor maior que o dano. A eficiência das medidas é parcial, estipulada em 150, embora, se bem aplicada, deveria ter sido total. Nestes termos, a indenização ficará da seguinte forma, dependendo do que for feito:

\begin{tabular}{|c|c|c|c|c|c|}
\cline { 2 - 6 } \multicolumn{1}{c|}{} & Dano & Medida 1 & Medida 2 & Eficiência & Indenização \\
\hline $\mathrm{H}_{1}$ & 200 & 100 & 300 & 150 & 100 \\
\hline $\mathrm{H}_{2}$ & 200 & Não existe & 300 & 150 & 150 \\
\hline
\end{tabular}




\begin{tabular}{|c|c|c|c|c|c|}
\hline $\mathrm{H}_{3}$ & 200 & Não existe & Não adota & Inaplicável & 200 \\
\hline $\mathrm{H}_{4}$ & 200 & Não adota & Não adota & Inaplicável & 0 \\
\hline
\end{tabular}

$\mathrm{H}_{1}$ : Coexistência de medida não onerosa e onerosa, sendo que o credor opta pela onerosa. A indenização é limitada ao valor da Medida 1, com o credor sofrendo dano efetivo de 50 e não sendo indenizado de 200 gastos com a Medida 2;

$\mathrm{H}_{2}$ : Existência apenas de medida onerosa, adotada pelo credor. A indenização é limitada ao valor do dano efetivamente mitigado, sofrendo o credor dano efetivo de 50;

$\mathrm{H}_{3}$ : Inexistindo medida adequada e que não seja onerosa, o credor não adota nenhuma medida. A indenização é limitada ao valor do dano sofrido;

$\mathrm{H}_{4}$ : Existindo medida adequada e que não seja onerosa, o credor não a adota, nem ao menos a onerosa. Não há indenização em razão da inércia do credor.

Solução:

a) Havendo coexistência de medidas adequadas, sendo que uma delas não é onerosa, pois a sua eficiência é maior que a despesa, o credor sofre maior pena em sua indenização, já que poderia ter optado de maneira a não agravar ainda mais a sua situação, exigindo valores além do dano mitigado;

b) Assim, quando a eficiência é maior que o valor da medida, indeniza-se pelo valor da medida;

c) Não havendo a alternativa de medida adequada que não é onerosa, e esta ainda assim tem eficiência parcial, será o credor ressarcido no valor do dano mitigado, já que não lhe cabia agir neste caso e a indenização total fomentaria o enriquecimento ilícito;

d) Não havendo qualquer conduta do credor, isto é, não mitigando o dano pois o duty to mitigate the loss assim não lhe impõe este ônus, o credor será ressarcido dos danos sofridos, haja vista que são inevitáveis;

e) Caso o credor não adote a Medida 1, quando existente, que não é onerosa pois de valor menor que o dano, não terá direito à indenização, pois os danos seriam na verdade evitáveis; 
f) Em todos os casos o credor não se beneficia de sua atuação irregular. Inclusive, a sua melhor opção é seguir os parâmetros aqui estabelecidos para a norma de mitigação, já que não tentar evitar os danos inevitáveis é o que lhe acarretaria no maior valor indenizatório.

\subsubsection{Exemplo 4: medidas com eficiência menor que o dano e que a medida adequada e não onerosa}

O dano a ser sofrido é estipulado em 200. Pode existir a Medida 1, na qual o credor gastaria 100, que não é onerosa. O credor optou pela Medida 2, na qual gasta 300, ou seja, é onerosa pois de valor maior que o dano. A eficiência das medidas é parcial, estipulada em 50, embora, se bem aplicada, deveria ter sido total. Nestes termos, a indenização ficará da seguinte forma, dependendo do que for feito:

\begin{tabular}{|c|c|c|c|c|c|}
\cline { 2 - 6 } \multicolumn{1}{c|}{} & Dano & Medida 1 & Medida 2 & Eficiência & Indenização \\
\hline $\mathrm{H}_{1}$ & 200 & 100 & 300 & 50 & 50 \\
\hline $\mathrm{H}_{2}$ & 200 & Não existe & 300 & 50 & 50 \\
\hline $\mathrm{H}_{3}$ & 200 & Não existe & Não adota & Inaplicável & 200 \\
\hline $\mathrm{H}_{4}$ & 200 & Não adota & Não adota & Inaplicável & 0 \\
\hline
\end{tabular}

$\mathrm{H}_{1}$ : Coexistência de medida não onerosa e onerosa, sendo que o credor opta pela onerosa. A indenização deveria ser limitada ao valor da Medida 1, com o credor sofrendo dano efetivo de 150 e não sendo indenizado de 200 gastos com a Medida 2. No entanto, como a eficiência foi só de 50, abaixo do valor da Medida 1, é por aquele que deve ser indenizado;

$\mathrm{H}_{2}$ : Existência apenas de medida onerosa, adotada pelo credor. A indenização é limitada ao valor do dano efetivamente mitigado, sofrendo o credor dano efetivo de 150;

$\mathrm{H}_{3}$ : Inexistindo medida adequada e que não seja onerosa, o credor não adota nenhuma medida. A indenização é limitada ao valor do dano sofrido; 
$\mathrm{H}_{4}$ : Existindo medida adequada e que não seja onerosa, o credor não a adota, nem ao menos a onerosa. Não há indenização em razão da inércia do credor.

Solução:

a) Mesmo quando a eficiência é menor que a despesa da medida adequada e que não é onerosa, as conclusões são as mesmas que as do Exemplo 3. O credor não se beneficia de sua atuação irregular em nenhum cenário. Sua melhor opção é, novamente, seguir os parâmetros aqui estabelecidos para a norma de mitigação;

b) Quando o valor da eficiência é menor que o valor da medida, indeniza-se por aquele valor, e não por este.

\subsubsection{Exemplo 5: medidas em que o credor aufere lucro}

O dano a ser sofrido é estipulado em 200. Pode existir a Medida 1, na qual o credor gastaria 100, que não é onerosa. O credor optou pela Medida 2, na qual gasta 300, ou seja, é onerosa pois de valor maior que o dano. A eficiência das medidas supera o dano, gerando lucro ao credor, sendo estipulada em 350. Nestes termos, a indenização ficará da seguinte forma, dependendo do que for feito:

\begin{tabular}{|c|c|c|c|c|c|c|}
\cline { 2 - 7 } \multicolumn{1}{c|}{} & Dano & Medida 1 & Medida 2 & Eficiência & Lucro & Indenização \\
\hline $\mathrm{H}_{1}$ & 200 & 100 & 300 & 350 & 50 & 50 \\
\hline $\mathrm{H}_{2}$ & 200 & 100 & $\begin{array}{c}\text { Não } \\
\text { existe/Não } \\
\text { adota }\end{array}$ & 350 & 250 & 0 \\
\hline $\mathrm{H}_{3}$ & 200 & Não existe & 300 & 350 & 150 & 50 \\
\hline $\mathrm{H}_{4}$ & 200 & Não existe & Não adota & Inaplicável & Inaplicável & 200 \\
\hline $\mathrm{H}_{5}$ & 200 & Não adota & Não adota & Inaplicável & Inaplicável & 0 \\
\hline
\end{tabular}


$\mathrm{H}_{1}$ : Coexistência de medida não onerosa e onerosa, sendo que o credor opta pela onerosa. A indenização é 50. Ela deve ser limitada ao valor da Medida 1. Como o credor teve lucro de 50 (300 gastos na Medida 2 subtraídos de 350 de eficiência), o dano já foi compensado e metade da indenização já foi ressarcida. Logo, faltam apenas 50 de indenização a serem pagas pelo devedor;

$\mathrm{H}_{2}$ : $\mathrm{O}$ credor adota a medida adequada que não é onerosa. A indenização é zero. Ela deveria ser limitada ao valor da Medida 1. Contudo, como o credor teve lucro de 250 (100 da Medida 1 subtraídos de 350 de eficiência), seu prejuízo já foi compensado;

$\mathrm{H}_{3}$ : Existência apenas de medida onerosa, adotada pelo credor. A indenização é 50 . Ela deve ser limitada ao valor do dano efetivamente mitigado. Como o credor teve lucro de 150 (200 do dano mitigado subtraídos de 350 de eficiência), o dano já foi compensado e três quartos da indenização já foram ressarcidas. Logo, faltam apenas 50 de indenização a serem pagas pelo devedor;

$\mathrm{H}_{4}$ : Inexistindo medida adequada e que não seja onerosa, o credor não adota nenhuma medida. A indenização é limitada ao valor do dano sofrido;

$\mathrm{H}_{5}$ : Existindo medida adequada e que não seja onerosa, o credor não a adota, nem ao menos a onerosa. Não há indenização em razão da inércia do credor.

\section{Solução:}

a) Havendo coexistência de medidas adequadas, sendo que uma delas não é onerosa e a eficiência das medidas é maior que o dano, o credor não só recebe indenização fragmentada, como seu lucro é baixo. Afinal, despendeu mais para obter um resultado que chegaria com menos gastos e com mesma eficiência;

b) Não receberá indenização se adotar medida adequada e não onerosa. Contudo, como agiu corretamente, é o caso em que irá auferir o maior lucro, pois gastou pouco e teve o maior retorno possível;

c) Não havendo a alternativa de medida adequada que não é onerosa, e esta tem eficiência que supera o valor do dano, o credor terá direito a indenização no montante que não alcançou seu lucro para chegar ao valor do dano efetivamente mitigado. Terá, no entanto, perdido valores em razão da adoção da medida onerosa; 
d) Não havendo qualquer conduta do credor, isto é, não mitigando o dano ante a inexistência de medida adequada e não onerosa, o credor será ressarcido dos danos sofridos, haja vista que são inevitáveis;

e) Caso o credor não adote a Medida 1, quando existente, que não é onerosa pois de valor menor que o dano, não terá direito à indenização, pois os danos seriam na verdade evitáveis;

f) Em todos os casos o credor não se beneficia de sua atuação irregular frente o devedor. Sua melhor opção é optar pela medida adequada e que não é onerosa quando existente, pois recuperará suas despesas com o maior lucro possível. Sendo o dano inevitável, é melhor não atuar, pois recuperará tudo o que perdeu sem ter qualquer desgaste, do mesmo jeito que aconteceria se agisse com medida adequada e onerosa quando inexistente uma que não seja onerosa.

\subsubsection{Exemplo 6: medidas em que o credor aufere lucro, sendo a medida não onerosa de mesmo valor que o dano e de eficiência menor que a medida onerosa}

O dano a ser sofrido é estipulado em 200. Pode existir a Medida 1, na qual o credor gastaria 200, que não é onerosa. O credor optou pela Medida 2, na qual gasta 300, ou seja, é onerosa pois de valor maior que o dano. A eficiência das medidas supera o dano, gerando lucro ao credor, sendo estipulada em 250. Nestes termos, a indenização ficará da seguinte forma, dependendo do que for feito:

\begin{tabular}{|c|c|c|c|c|c|c|}
\cline { 2 - 7 } \multicolumn{1}{c|}{} & Dano & Medida 1 & Medida 2 & Eficiência & Lucro & Indenização \\
\hline $\mathrm{H}_{1}$ & 200 & 200 & 300 & 250 & 50 & 150 \\
\hline $\mathrm{H}_{2}$ & 200 & 200 & $\begin{array}{c}\text { Não } \\
\text { existe/Não } \\
\text { adota }\end{array}$ & 250 & 50 & 150 \\
\hline $\mathrm{H}_{3}$ & 200 & Não existe & 300 & 250 & 50 & 150 \\
\hline $\mathrm{H}_{4}$ & 200 & Não existe & Não adota & Inaplicável & Inaplicável & 200 \\
\hline
\end{tabular}




\begin{tabular}{|l|l|l|l|l|l|c|}
\hline $\mathrm{H}_{5}$ & 200 & Não adota & Não adota & Inaplicável & Inaplicável & 0 \\
\hline
\end{tabular}

$\mathrm{H}_{1}$ : Coexistência de medida não onerosa e onerosa, sendo que o credor opta pela onerosa. A indenização é 150. Ela deve ser limitada ao valor da Medida 1. Como o credor teve "lucro" (na verdade está perdendo 100 em função dos 300 investidos, mas é eficiente em 50 a mais que os 200 do dano) de 50, este já foi compensado e um quarto da indenização já foi ressarcido. Logo, faltam apenas 150 de indenização a serem pagas pelo devedor;

$\mathrm{H}_{2}$ : $\mathrm{O}$ credor adota a medida adequada e que não é onerosa. A indenização é 150. Ela deve ser limitada ao valor da Medida 1. Como o credor teve lucro de 50 (200 da Medida 1 subtraídos de 250 de eficiência), um quarto de seu prejuízo já foi compensado, faltando apenas 150 de indenização a serem pagas pelo devedor;

$\mathrm{H}_{3}$ : Existência apenas de medida onerosa, adotada pelo credor. A indenização é 150. Ela deve ser limitada ao valor do dano efetivamente mitigado. Como o credor teve "lucro" (na verdade está perdendo 100 em função dos 300 investidos, mas é eficiente em 50 a mais que os 200 do dano) de 50, este já foi compensado e um quarto da indenização já foi ressarcido. Logo, faltam apenas 150 de indenização a serem pagas pelo devedor;

$\mathrm{H}_{4}$ : Inexistindo medida adequada e que não seja onerosa, o credor não adota nenhuma medida. A indenização é limitada ao valor do dano sofrido;

$\mathrm{H}_{5}$ : Existindo medida adequada e que não seja onerosa, o credor não a adota, nem ao menos a onerosa. Não há indenização em razão da inércia do credor.

\section{Solução:}

a) Havendo coexistência de medidas adequadas, sendo que uma delas não é onerosa e a eficiência é menor que a medida onerosa, mas maior que o dano, o credor não só recebe indenização fragmentada, como ainda terá perdido valores. Afinal, despendeu mais para obter um resultado que chegaria com menos gastos e com mesma eficiência;

b) Se adotar medida adequada e não onerosa, receberá indenização fragmentada em razão do lucro que obterá. Neste cenário, não teve nenhuma perda, pois gastou exatamente o que recebeu; 
c) Não havendo a alternativa de medida adequada que não é onerosa, e esta tem eficiência que supera o valor do dano, o credor terá direito a indenização no montante que não alcançou seu lucro para chegar ao valor do dano efetivamente mitigado. Terá, no entanto, perdido valores em razão da adoção da medida onerosa;

d) Não havendo qualquer conduta do credor, isto é, não mitigando o dano ante a inexistência de medida adequada e não onerosa, o credor será ressarcido dos danos sofridos, haja vista que são inevitáveis;

e) Caso o credor não adote a Medida 1, quando existente, que não é onerosa pois de valor equivalente ao do dano, não terá direito à indenização, pois os danos seriam na verdade evitáveis;

f) Em todos os casos o credor não se beneficia de sua atuação irregular frente o devedor. Sua melhor opção é optar pela medida adequada e que não é onerosa quando existente, pois recuperará suas despesas sem perder qualquer valor no processo. Sendo o dano inevitável, é melhor não atuar, pois recuperará tudo o que perdeu sem ter qualquer perda, o que aconteceria se agisse com medida adequada e onerosa quando inexistente uma que não seja onerosa.

\subsubsection{Exemplo 7: medida adequada e não onerosa sem gasto e oscilação de mercado}

As partes realizam um contrato de compra e venda, com o produto valendo 200 . No termo estipulado, o devedor se torna inadimplente. O credor, para mitigar seu prejuízo, revende o produto por 150, valor máximo que poderia obter em razão da oscilação do seu valor no mercado. A revenda não importou em qualquer despesa adicional para o credor. Nestes termos, a indenização ficará da seguinte forma, dependendo do que for feito:

Resolução:

A regra de aferição da razoabilidade serve para determinar a evitabilidade do dano. Logo, o seu desenvolvimento se dá apenas sobre os danos evitáveis. O credor só poderia evitar 150, já que este é o valor máximo que poderia obter no mercado. Logo, o cálculo da indenização na regra de aferição da razoabilidade é feito em cima de 150 apenas. Assim: 


\begin{tabular}{|c|c|c|c|c|}
\cline { 2 - 5 } \multicolumn{1}{c|}{} & Dano & Medida & Eficiência & Indenização \\
\hline $\mathrm{H}_{1}$ & 150 & 0 & 150 & 0 \\
\hline
\end{tabular}

Dessa maneira, quanto aos danos evitáveis, o credor não receberá qualquer indenização, já que não despendeu nada para evitar o dano e já foi ressarcido com a revenda. Contudo, o dano total da inadimplência é de 200, conforme contrato havido entre as partes. Só que os 50 são danos inevitáveis, já que impossíveis de serem recuperados pelo credor no mercado. Portanto, a indenização total do credor será apenas de 50 pelos danos inevitáveis. 


\section{APÊNDICE: Síntese da regra de aferição da razoabilidade}

Na iminência ou efetiva ocorrência de um prejuízo imputável ao devedor em razão de um inadimplemento, para a aferição da incidência do duty to mitigate the loss ao caso e, consequentemente, ter o credor o ônus de mitigar, devem ser seguidas as seguintes etapas:

\begin{tabular}{|l|l|}
\hline \multicolumn{2}{|c|}{$1^{\text {a }}$ parte: verificação pelo credor da razoabilidade da medida a ser por ele adotada } \\
\hline I) a medida a ser tomada é adequada? & $\begin{array}{l}\text { - Se sim, parte-se para o item II. } \\
\text { - Se não, a medida é inadequada, então outra } \\
\text { alternativa deve ser adotada (se existente) } \\
\text { ou o dano é inevitável. Logo, o credor } \\
\text { deverá, respectivamente, pensar em } \\
\text { alternativa para reiniciar a primeira parte ou } \\
\text { onerosa? }\end{array}\left|\begin{array}{l}\text { ser indenizado por todo o dano. } \\
\hline\end{array}\right| \begin{array}{l}\text { ônus de mitigar. } \\
\text { - Se não, o dano é evitável, existe o ônus de } \\
\text { mitigar. }\end{array}$ \\
\hline
\end{tabular}

\begin{tabular}{|l|l|}
\hline \multicolumn{2}{|c|}{$2^{\text {a }}$ parte: verificação pelo magistrado da razoabilidade da medida adotada pelo credor } \\
\hline I) a medida tomada foi adequada? & $\begin{array}{l}\text { - Se sim, parte-se para o item II. } \\
\text { - Se não, a medida é inadequada, então outra } \\
\text { alternativa deveria ter sido adotada (se } \\
\text { existente) ou o dano é inevitável. Logo, o } \\
\text { credor deverá ser indenizado apenas pelos } \\
\text { danos inevitáveis. }\end{array}$ \\
\hline $\begin{array}{l}\text { II) a medida tomada foi perigosa e/ou } \\
\text { onerosa? }\end{array}$ & $\begin{array}{l}\text { - Se sim, o dano era inevitável e o credor } \\
\text { não tinha o ônus de mitigar. Parte-se para o } \\
\text { item III. }\end{array}$ \\
\hline
\end{tabular}




\begin{tabular}{|c|c|}
\hline & $\begin{array}{l}\text { - Se não, o dano era evitável e o credor tinha } \\
\text { o ônus de mitigar. Parte-se para o item III. }\end{array}$ \\
\hline III) qual o grau de eficiência da medida? & $\begin{array}{l}\text { - Total: } \\
\text { a) não perigosa nem onerosa: indenização } \\
\text { pelas despesas e danos inevitáveis; } \\
\text { b) perigosa: indenização pelas despesas e } \\
\text { outros danos inevitáveis; } \\
\text { c) onerosa: indenização pelas despesas na } \\
\text { extensão do dano mitigado e outros danos } \\
\text { inevitáveis; } \\
\text { d) perigosa e onerosa: indenização pelas } \\
\text { despesas na extensão do dano mitigado e } \\
\text { outros danos inevitáveis; } \\
\text { e) coexistência de medidas: } \\
\text { e.1.) com perigosa: se opta pela perigosa, } \\
\text { indenização pelas despesas e outros danos } \\
\text { inevitáveis; } \\
\text { e.2.) com onerosa: se opta pela onerosa, } \\
\text { indenização pelas despesas na extensão da } \\
\text { medida não onerosa e não perigosa e outros } \\
\text { danos inevitáveis; } \\
\text { e.3.) com perigosa e onerosa: se opta pela } \\
\text { perigosa e onerosa, indenização pelas } \\
\text { despesas na extensão do dano mitigado e } \\
\text { outros danos inevitáveis;. }\end{array}$ \\
\hline & $\begin{array}{l}\text { - Parcial: } \\
\text { a) não perigosa nem onerosa: indenização } \\
\text { pelas despesas na extensão do dano }\end{array}$ \\
\hline
\end{tabular}




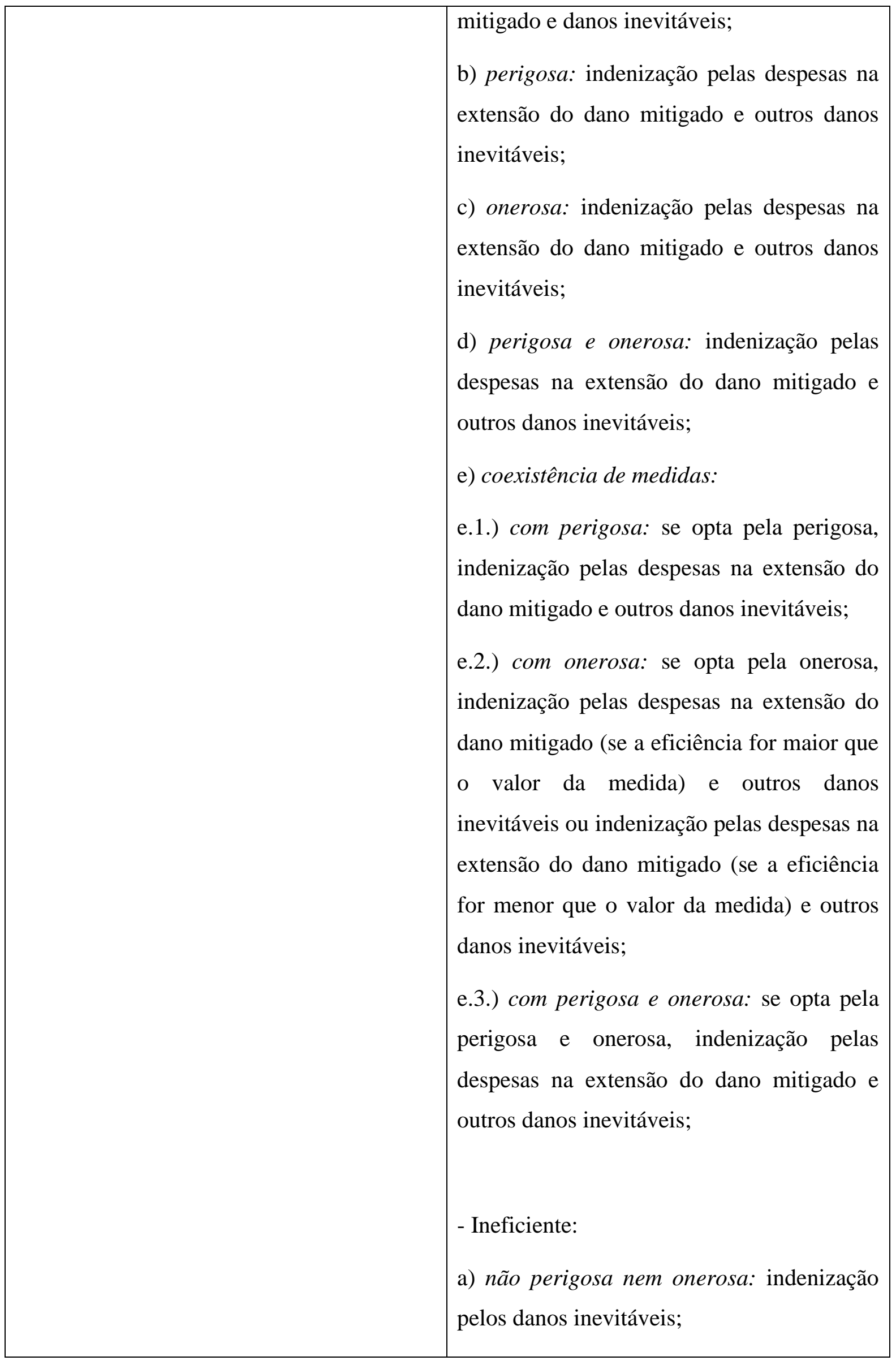




\begin{tabular}{|c|c|}
\hline & $\begin{array}{l}\text { b) perigosa: indenização pelos danos } \\
\text { inevitáveis; } \\
\text { c) onerosa: indenização pelos danos } \\
\text { inevitáveis; } \\
\text { d) perigosa e onerosa: indenização pelos } \\
\text { danos inevitáveis; } \\
\text { e) coexistência de medidas: } \\
\text { e.1.) com perigosa: indenização pelos danos } \\
\text { inevitáveis; } \\
\text { e.2.) com onerosa: indenização pelos danos } \\
\text { inevitáveis; } \\
\text { e.3.) com perigosa e onerosa: indenização } \\
\text { pelos danos inevitáveis; }\end{array}$ \\
\hline $\begin{array}{l}\text { IV) } \mathrm{O} \text { credor obteve algum lucro com a } \\
\text { medida? }\end{array}$ & $\begin{array}{l}\text { - Se sim, há compensação entre o quantum } \\
\text { obtido no item III e o lucro para se chegar } \\
\text { ao valor final da indenização; } \\
\text { - Se não, o valor indenizatório já está } \\
\text { definido. }\end{array}$ \\
\hline
\end{tabular}




\section{O DUTY TO MITIGATE THE LOSS NA JURISPRUDÊNCIA BRASILEIRA}

No presente capítulo será verificada a atual aplicação do duty to mitigate the loss pelos Tribunais brasileiros. A pesquisa foi realizada em todos os Tribunais de Justiça, Tribunais Regionais Federais, no Superior Tribunal de Justiça e no Supremo Tribunal Federal. Daquelas cortes que foram encontradas menções à norma de mitigação, foram objeto de análise somente os acórdãos pertinentes ao Direito Civil, excluindo-se os resultados referentes ao Direito Processual e Direito Penal.

Além disso, daqueles tribunais que continham menos que cinco decisões citando o duty to mitigate the loss, todas elas foram incorporadas a este estudo e analisadas. Dos que tinham mais que cinco, foram selecionadas decisões representativas de diferentes aspectos da controvérsia na aplicação jurisprudencial brasileira da norma de mitigação.

As decisões foram agrupadas em três grandes grupos: aquelas que aplicaram corretamente a mitigação do prejuízo, aquelas que o aplicaram de maneira parcialmente correta e aquelas que o aplicaram incorretamente. Dentro de cada grupo, um subitem traz já em seu título um resumo dos elementos essenciais que foram objeto de análise no caso e, em cada um deles, a controvérsia foi analisada primeiramente com uma síntese dos fatos seguida da análise e justificativa do porquê de a decisão ter aplicado correta ou incorretamente o duty to mitigate the loss.

Aproveita-se a oportunidade e também já se demonstra a viabilidade de aplicação da regra de aferição da razoabilidade nos casos em que houve a aplicação correta ou parcialmente correta da norma de mitigação. Para tanto, verifica-se a presença da adequação, onerosidade, periculosidade, eficiência e lucratividade da medida adotada pelo credor. A ressalva, contudo, fica na impossibilidade de aplicação detalhada da regra na maioria dos casos, tendo em vista que em quase todos os acórdãos não constam valores despendidos pelas partes e, com isso, obsta a verificação exauriente da regularidade do quantum indenizatório fixado. Para este aprofundamento, faz-se referência aos exemplos trazidos no Capítulo anterior, item 5.7. 


\subsection{Decisões com aplicação correta do duty to mitigate the loss}

\subsubsection{Duty to mitigate the loss e medida inadequada ${ }^{351}$}

Houve a celebração de uma promessa de contrato de compra e venda de um imóvel entre a autora e o réu. O réu, promitente-comprador, deixou de pagar as parcelas devidas em 1994 e, posteriormente em setembro de 2001, abandonou o imóvel. A autora, promitente-vendedora, propôs ação de reintegração de posse cumulada com indenização só em 2002, alegando não poder ingressar no imóvel e, por isso ter perdas e danos imputáveis ao réu.

Restou assentado na decisão que a autora demorou quase sete anos para ajuizar a ação, contados desde a inadimplência do réu. Tal postura é contrária à boa-fé objetiva e, por conseguinte, ao duty to mitigate the loss. Além disso, a autora nem ao menos se dispôs a verificar a situação do imóvel quando do ajuizamento da ação, já que saberia que ele já estava vazio, sendo desnecessário o pedido de reintegração de posse. A ausência de zelo da autora pelo seu patrimônio permitiu o agravamento de seu próprio dano.

A decisão está correta na aplicação da norma de mitigação. Realmente, a autora não observou o duty to mitigate the loss, já que o alegado prejuízo sofrido foi arcado com a desatenção ao fato de o imóvel já estar desocupado. Sendo assim, a autora tinha o ônus de mitigar, realizando atividades - como a locação, por exemplo - para diminuir seu dano.

Transportando para a regra de aferição da razoabilidade, a medida adotada pela autora não chega nem ao menos a ser adequada, pois não existia posse a ser-lhe devolvida. Assim, não ultrapassando nem ao menos a primeira etapa, não poderá ser indenizada. $\mathrm{O}$ prejuízo sofrido, neste caso, era evitável, já que havia outras medidas adequadas disponíveis.

\footnotetext{
${ }^{351}$ BRASIL. Superior Tribunal de Justiça, $3^{\text {a }}$ Turma. Recurso Especial n ${ }^{\text {o } 758.518 / P R . ~ R e c o r r e n t e: ~ M u r e t a m a ~}$ Edificações e Empreendimentos Ltda. Recorrido: Sérgio Meca de Lima. Rel. Min. Vasco Della Giustina (Desembargador convocado do TJ/RS), votação unânime, j. 17/06/2010.
} 


\subsubsection{Medida de mitigação definida por cláusula contratual ${ }^{352}$}

As partes celebraram compromisso de compra e venda, regido pelo direito do consumidor, com cláusulas que impediam o devedor de adimplir a parcela da prestação atual sem o adimplemento das anteriores. Entendo ser a cláusula abusiva, o consumidor propôs ação revisional, julgada procedente em primeira instância. Na apelação os desembargadores não reformaram a decisão neste ponto, justificando que houve inobservância do duty to mitigate the loss com a estipulação desta cláusula, considerada abusiva. Afinal, ela só tenderia à acumulação do débito.

A norma de mitigação, no caso, foi bem aplicada. A medida adotada pelo credor para mitigar seu prejuízo, qual seja, estipular cláusula de limitação do adimplemento das parcelas pelo devedor, não se mostra razoável. Ainda que fomente o fim almejado se determinadas circunstâncias forem preenchidas, como o devedor pagando as parcelas atrasadas e logo após continuando o pagamento das demais parcelas vincendas normalmente, pode-se considerar a medida adequada.

No entanto, a medida é onerosa, já que o prejuízo trazido pelos sucessivos inadimplementos (haja vista que o devedor não poderá pagar as parcelas vincendas enquanto não saldar sua dívida) é maior do que o prejuízo que teria se rescindisse prontamente o contrato ou deixasse que o devedor pagasse as parcelas normalmente, cobrando apenas o montante em que se manteve inadimplente. Assim, a cláusula estipulada pelo credor que limita o adimplemento não se presta à mitigação: ao contrário, só faz com que o débito aumente, agravando ainda mais a sua situação.

\subsubsection{Inobservância do duty to mitigate the loss ${ }^{353}$}

Em 10 de dezembro de 2005 a autora teve seus documentos e talão de cheque roubados. No dia 04 de janeiro de 2006, foram efetuadas várias compras no

\footnotetext{
352 BRASIL. Tribunal de Justiça do Estado de São Paulo, $1^{\text {a }}$ Câmara de Direito Privado. Apelação Cível $\mathrm{n}^{\mathrm{o}}$ 0006445-52.2005.8.26.0586. Apelantes: Laerte de Paiva Filho e outros. Apelado: Ariovaldo Furlanetto. Rel. Des. Cláudio Godoy, votação unânime, j. 12/03/2013.

${ }^{353}$ BRASIL. Tribunal de Justiça do Estado do Rio Grande do Sul, $6^{\mathrm{a}}$ Câmara Cível. Apelação Cível $\mathrm{n}^{\mathrm{o}}$ 70028036465. Apelante/Apelado: Tatiane Klein Gomes e Lojas Radan Ltda. Rel. Des. Liége Puricelli Pires, votação unânime, j. 09/04/2009.
} 
estabelecimento da ré em nome da autora. A autora, por sua vez, só informou do roubo o Serviço de Proteção ao Crédito (SPC) em 09 de fevereiro de 2006, mas ainda assim, em 10 de junho de 2006, a ré enviou a dívida para cadastramento negativo. Inconformada com a negativação de seu nome e os prejuízos havidos com o roubo, a autora propôs ação declaratória cumulada com pedido de indenização por danos morais.

A sentença de primeira instância julgou o pedido parcialmente procedente, declarando inexistente o contrato havido com a ré, condenando a ré por danos morais e determinando o cancelamento do nome da autora do cadastro do SPC. Da sentença, a autora recorreu pedindo majoração do valor dos danos morais e a ré pela reforma total da sentença.

O Tribunal decidiu que houve concorrência de culpa da autora no evento danoso, haja vista que transcorreu um considerável lapso temporal entre o roubo e a sua comunicação para o SPC. Então, reconhecendo que a autora deveria ter mitigado seu dano e, aplicando o duty to mitigate the loss, os desembargadores decidiram manter o valor da condenação por danos morais, considerando-o suficiente.

A aplicação da norma de mitigação, no caso, está correta. Embora o acórdão inicie sua análise fazendo referência à culpa concorrente - o que se afigura como um erro fundamental, conforme visto no Título I, Capítulo 3, item 3.2.1. - é posteriormente aplicado adequadamente o duty to mitigate the loss, haja vista que, se a autora tivesse avisado desde logo o SPC do roubo, não teria sofrido a ação criminosa dos falsários. Seus prejuízos, portanto, teriam sido mitigados.

Tratava-se de medida adequada, não perigosa e não onerosa: fomenta o fim almejado (impedir o uso criminoso de seus documentos), não traz risco de vida à autora (ao contrário: impede que ela corra riscos) e não é onerosa (bastava uma ligação, carta ou comunicação pessoal do ocorrido). Por estes prejuízos, então, a autora não teria o direito de ser indenizada.

Embora a decisão tenha concedido indenização por dano moral por todos os dissabores sofridos pela autora, é certo que esta deveria ser devida somente em razão da negativação equivocada, após a comunicação da autora ao SPC do roubo. Este ponto, contudo, não se relaciona com a norma de mitigação, motivo pelo qual não se avançará na análise. 
O Tribunal de Justiça do Estado de Santa Catarina possui também jurisprudência ${ }^{354}$ sobre um locatário que não se atentou ao duty to mitigate the loss, não adotando como medida razoável a comunicação ao locador da existência de danos estruturais no imóvel. Em outro julgado ${ }^{355}$, o proprietário de um terreno que sofreu danos da construção irregular do vizinho, mas não permitiu a entrada deste para a manutenção e regularização da obra. Não adotando qualquer medida razoável, não foi indenizado.

\subsubsection{Duty to mitigate the loss e onerosidade $\mathrm{e}^{356}$}

Os litigantes sofreram acidente automobilístico, com a colisão do veículo conduzido pelo réu na traseira do automóvel em que se encontravam os autores, causando ferimentos de ordem física e estética, bem como danos nos veículos de ambos. Os autores, então, propuseram ação indenizatória pleiteando ressarcimento pelo valor do reparo aos danos ao veículo, despesas odontológicas, estéticas e de internação em apartamento, além de danos morais.

Em primeira instância o juiz julgou parcialmente procedente a demanda, condenando o réu a danos morais e danos materiais sobre os danos estéticos e limitando o valor da indenização sobre o automóvel ao seu valor de mercado. Foi negado o valor pleiteado pela internação, entendendo o magistrado que se tratava de medida excessiva, já que o plano de saúde cobria o valor de internação em ambulatório e não em apartamento.

Inconformados, os autores e réu interpuseram recurso de apelação, pedindo a reforma da sentença. Os desembargadores então deram parcial provimento a ambos os recursos, ratificando a decisão do juiz de primeira instância de limitar o valor da indenização do veículo ao seu valor de mercado e não ao do reparo daquele que fora avariado, tendo em vista que o conserto ficaria mais caro que a aquisição de um novo. Além disso, mantiveram também a negativa de indenização pela acomodação em

\footnotetext{
${ }^{354}$ BRASIL. Tribunal de Justiça do Estado de Santa Catarina, 6 a Câmara de Direito Civil. Apelação Cível n ${ }^{\circ}$ 2012.036092-7. Apelante: Luci Video Locadora Ltda. Apelado: Valter Valdemiro Rodrigues Filho. Rel. Des. Ronei Danielli, votação unânime, j. 07/11/2013.

${ }^{355}$ BRASIL. Tribunal de Justiça do Estado de Santa Catarina, $6^{\text {a }}$ Câmara de Direito Civil. Apelação Cível ${ }^{\circ}$ 2010.022856-8. Apelantes/Apelados: Luiz Olynto Teixeira Schirmer, Ilze Irmgard Schertel Cruz e o espólio de Léo Alberto Ramos Cruz. Rel. Des. Ronei Danielli, votação unânime, j. 19/10/2012.

356 BRASIL. Tribunal de Justiça do Estado de Minas Gerais, 16 ${ }^{a}$ Câmara Cível. Apelação Cível $n^{\circ}$ 1.0701.07.183692-1/001. Apelantes/Apelados: Julio Ferreira dos Santos e outro e Felipe Raffaeli Ramos. Rel Des. Wagner Wilson, votação unânime, j. 11/03/2009.
} 
apartamento ao invés do ambulatório, já que não foi demonstrada qualquer necessidade de internação em local mais caro. Ambos os entendimentos foram fundados no duty to mitigate the loss.

Foi acertado o entendimento do Tribunal mineiro. E isto é facilmente verificado pela regra de aferição da razoabilidade. No caso do automóvel, o seu conserto até poderia ser uma medida adequada e não perigosa; entretanto, tratava-se de medida onerosa, tendo em vista que o valor do reparo era superior ao de aquisição de um veículo novo. Logo, a medida razoável não era o conserto, e sim, a compra de um novo automóvel.

Quanto à internação, a colocação em um apartamento poderia até ser uma medida adequada e não perigosa, mas igualmente ao caso do veículo, tratava-se de medida simplesmente onerosa, já que não traria ao paciente qualquer benefício ao seu tratamento a não ser a mera comodidade. Por isso, era razoável a internação em ambulatório, assim como seu plano de saúde cobria.

Poderia ser considerada uma medida razoável se a internação no local trouxesse perigo à saúde do paciente (como, por exemplo, se fosse o caso das acomodações serem precárias a ponto de prejudicar o tratamento) ou o próprio plano de saúde cobrisse as despesas. Assim, no primeiro caso, manter os autores em ambulatório seria uma medida perigosa. No segundo, não haveria qualquer onerosidade, sendo uma alternativa viável e até recomendável, já que traria maiores vantagens pelo mesmo custo.

\subsubsection{Duty to mitigate the loss e pagamento de dívida indevida ${ }^{357}$}

A autora mantém contrato de serviços de telefonia com a ré. Em certa data, foi cobrada indevidamente pela ré sobre a utilização de seus serviços. Inconformada, a autora entrou em contato com a ré, que lhe informou que em breve lhe incluiria no cadastro de consumidores inadimplentes. Para não ter problemas com a negativação de seu nome, a autora pagou a dívida indevida e logo em seguida propôs ação de indenização por danos materiais e morais contra a ré.

\footnotetext{
${ }^{357}$ BRASIL. Tribunal de Justiça do Estado de Pernambuco, $3^{\text {a }}$ Câmara Cível. Agravo Regimental no 304623 5. Agravantes/Agravados: Tim Nordeste S.A. e Climart Comércio e Serviço Ltda. Rel Des. Bartolomeu Bueno, votação unânime, j. 05/12/2013.
} 
Em primeira instância, os pedidos foram julgados parcialmente procedentes, arbitrando o magistrado indenização moral por valor menor do que pleiteado pela autora. Ambas as partes interpuseram recurso de apelação contra esta decisão, os quais não foram admitidos pelo Tribunal. Insistiram as partes, interpondo recurso de agravo regimental. Neles, os desembargadores decidiram dar provimento parcial ao recurso da ré e negarem provimento ao da autora. Afirmou-se na decisão que a autora merecia ser indenizada pelos danos morais e pelos valores dispendidos no pagamento da dívida cobrada irregularmente, haja vista que, com esta atitude, mitigou seu prejuízo, agindo conforme a boa-fé objetiva.

A aplicação do duty to mitigate the loss neste caso está correta. A autora, para evitar os prejuízos decorrentes da inclusão do seu nome no cadastro de inadimplentes, pagou dívida, mesmo sabendo que indevida. Foi atenta ao fato de que a negativação seria muito mais prejudicial do que o mero pagamento da suposta dívida e discussão judicial posteriormente para o devido ressarcimento. A autora se antecipou a um dano maior que certamente sofreria além da cobrança indevida que já ocorria. Por ter adotado uma medida razoável (adequada, não perigosa e não onerosa), realmente merecia ser indenizada pelas despesas havidas.

\subsection{Decisões com aplicação parcialmente correta do duty to mitigate the loss}

\subsubsection{Duty to mitigate the loss, onerosidade e dever de informação do credor $^{358}$}

A consumidora, ora autora, contratou os serviços da ré para a realização de reparos em sua instalação elétrica e, com isso, obter um desconto na sua conta de luz. Todavia, para que o desconto fosse realizado, era necessário que houvesse comunicação por parte da ré à concessionária de distribuição de energia elétrica. Esta medida não foi tomada e, ao longo de seis meses, a conta de luz da autora veio sem o desconto.

Inconformada, a autora entrou em contato com a ré, que finalmente fez o contato necessário com a concessionária de distribuição de energia elétrica e a partir de então a conta de luz veio com o devido desconto. A autora, então, propôs ação de indenização

\footnotetext{
358 BRASIL. Tribunal de Justiça do Estado do Rio de Janeiro, 16 $6^{\text {a }}$ Câmara Cível. Apelação Cível $n^{\circ}$ 2008.001.45909. Apelante: Coopergia Cooperativa de Serviços em Energia Ltda. Apelada: Mercado Super Mikey da Praça Ltda. Rel. Des. Eduardo Gusmão Alves de Brito Neto, votação unânime, j. 16/09/2008.
} 
contra a ré, pleiteando os valores excedentes pagos nos seis meses anteriores à comunicação.

O Tribunal considerou que a autora não observou o duty to mitigate the loss, já que deixou de comunicar, desde logo, a falta de desconto na sua conta de luz. Se assim tivesse procedido, não teria arcado com tamanho prejuízo. Não teria como a ré saber que a conta de luz da autora estava sem o desconto se esta não lhe informasse disto. Deu, então, parcial provimento ao recurso, limitando a indenização a três meses.

A decisão está correta ao aplicar o duty to mitigate the loss, mas não quanto a consequência de limitação da indenização. Ainda que a obrigação de comunicar a concessionária de distribuição de energia elétrica fosse da ré - e ela não a tenha cumprido tempestivamente -, a autora não precisaria arcar ao longo de seis meses com uma conta de luz mais cara se desde logo tivesse avisado deste fato. Houve um inadimplemento pela ré (falta de comunicação) e a medida razoável era informar a ré do seu descumprimento. Afinal, conforme restou consignado no acórdão, a ré não sabia ou não tinha como saber que as cobranças estavam sendo indevidas. Desse modo, não se pode dizer que a autora não tinha como evitar ou minimizar o dano, pois era a única apta a tanto.

Consoante a regra de aferição da razoabilidade, a medida adequada, não onerosa e não perigosa era a comunicação, de pronto, da ausência de descontos na conta de luz, ou seja, após a primeira cobrança indevida. Contudo, a autora optou por uma medida adequada e não perigosa, porém onerosa. Assim, não teria direito de ser indenizada pelo excedente na conta de luz proporcional ao desconto.

O equívoco da decisão consiste na indenização por três meses, já que o único dano inevitável era a cobrança excedente do primeiro mês, quando a autora tivesse ciência da falta de comunicação da ré sobre os serviços prestados. Desta parcela a autora poderia ser indenizada, mas não dos demais dois meses. 


\subsubsection{Duty to mitigate the loss, verificação do quantum indenizatório e ônus probatório $^{359}$}

A autora adquiriu em 20 de dezembro de 2005 da empresa ré uma máquina de eletroerosão com cerca de 40 anos de vida no valor de $\mathrm{R} \$ 12.500,00$ que, no dia da entrega, já não funcionava por um dito problema elétrico. Após diversas tratativas com a ré, foi enviado um técnico que constatou que não se tratava de problema elétrico, e sim, hidráulico. O conserto só foi realizado em 20 de fevereiro de 2006. No entanto, mesmo com a máquina funcionando, a autora não conseguiu utilizá-la dada a sua complexidade e falta de mão de obra qualificada, o que levantou a suspeita de má utilização quando ela quebrou pela primeira vez.

Então, após várias negociações, foi adquirida outra máquina, mais cara no importe de $\mathrm{R} \$ 3.100,00$ e utilizando a primeira como parte do pagamento, em 28 de abril de 2006, arcando a ré com todas as despesas no valor de $\mathrm{R} \$ 4.120,24$ referentes ao conserto e manutenção da primeira máquina. Assim, nos quatro meses que a máquina antiga ficou parada na empresa, a autora sofreu grandes prejuízos.

Por isso, a autora pleiteou indenização por lucros cessantes, em que o menor orçamento trazido aos autos aponta o valor hora de $\mathrm{R} \$ 35,00$, o que, aplicado ao período compreendido entre 20 de dezembro de 2005 e 28 de abril de 2006, corresponde a 848 horas paradas, totalizando a quantia de $\mathrm{R} \$ 25.440,00$. Também pleiteou a soma das despesas efetuadas na compra de outra máquina, de $\mathrm{R} \$ 3.100,00$, mais as despesas de frete, de $\mathrm{R} \$ 100,00$, e a assistência técnica de $\mathrm{R} \$ 346,70$, totalizando $\mathrm{R}$ \$28.986,70.

Houve contestação e réplica. Em sentença, o juiz julgou a causa parcialmente procedente, condenando a ré a ressarcir a autora somente quanto aos valores de frete e assistência técnica. Inconformada, a autora interpôs recurso de apelação.

O Tribunal deu parcial provimento ao apelo, mas apenas quanto ao ônus de sucumbência. Quanto à questão central do apelo, foi afastada a tese da autora pela aplicação do duty to mitigate the loss, afirmando que não se pode afirmar que a máquina adquirida produziria o que fora alegado, tendo em conta o seu natural desgaste. Além

${ }^{359}$ BRASIL. Tribunal de Justiça do Estado do Rio Grande do Sul, $5^{\text {a }}$ Câmara Cível. Apelação Cível $n^{\circ}$ 70025609579. Apelante: Prakasa Indústria e Comércio de Utilidades do Lar Ltda. Apelada: Mercomáquinas Indústria Comércio e Representações Ltda. Rel. Des. Umberto Guaspari Sudbrack, votação unânime, j. 20/05/2009. 
disso, faltou à autora tomar medidas razoáveis, como adquirir outra máquina que desempenhasse a mesma função, ou mesmo celebrar contrato de prestação do referido serviço com outra empresa, para mitigar seu prejuízo.

O raciocínio do Tribunal está parcialmente correto na aplicação do duty to mitigate the loss. Realmente, fica estampado no caso que a autora não se desincumbiu de seu ônus de mitigação e, por isso, não lhe cabe o reembolso pelos prejuízos sofridos. Com efeito, aplicando a regra de aferição da razoabilidade, isto é facilmente constatado.

A medida adotada pela autora foi adequada, haja vista que fomenta o fim almejado, isto é, o conserto da máquina antiga e compra de um equipamento novo serve para interromper a cadeia de perdas e danos. Não é também perigosa, já que não lhe traz qualquer risco de vida. No entanto, a medida é onerosa, haja vista que o tempo que levou para adotá-la e os ditos lucros que deixou de auferir demonstram ser mais prejudicial do que se tivesse tomado as medidas exemplificadas no acórdão.

O dano pelos lucros cessantes que iria sofrer era no importe de $\mathrm{R} \$ 25.440,00$. Primeiro, gastou R\$ 346,70 com o conserto e R\$100,00 com o frete para impedir esta perda, o que foi infrutífero. Então, gastou mais R \$ 3.100,00 (além de entregar a máquina consertada adquirida antes como parte do pagamento) para adquirir nova máquina e impedir a continuidade do seu dano. Logo, gastou $\mathrm{R} \$ 3.546,70$ na medida que considerava razoável e ainda assim só foi capaz de interromper a continuidade de produção dos prejuízos. Por outro lado, se tivesse desde o começo adquirido outra máquina, ou seja, gastado R \$3.100,00 somente (já que sabia, conforme se verifica na decisão, que o conserto demoraria), não teria sofrido com a perda de $\mathrm{R} \$ 25.440,00$, haja vista que desde o início evitaria a produção do prejuízo. Por isso, a medida escolhida pela autora não foi razoável, dada a sua onerosidade.

Poder-se-ia discutir também outra medida adequada, mais onerosa que a aquisição de nova máquina, mas menos onerosa do que a medida adotada pela autora no caso, que seria a aquisição de uma nova máquina enquanto se realiza o conserto da primeira. $O$ gasto total seria de $\mathrm{R} \$ 16.046,70$ ( $\mathrm{R} \$ 15.600,00$ da máquina nova somado com $\mathrm{R} \$ 446,70$ do conserto e frete). Não seria a medida razoável, dada a possibilidade da medida menos onerosa ser a anteriormente exposta, mas ainda assim, seria uma alternativa melhor.

Há também a hipótese trazida pelo desembargador relator de contratação de prestadora de serviço para suprir a atividade da máquina quebrada. Entretanto, um melhor 
desenvolvimento desta situação fica impedido por conta da ausência de valores informados no processo.

O equívoco desta decisão incide no valor da indenização fixado: a somatória do conserto e do frete. Deveria ser o valor despendido na aquisição da nova máquina pela autora ( $\mathrm{R} \$ 3.100,00)$. Isto porque a medida adotada por ela, apesar de onerosa, foi totalmente eficiente, já que mitigou os danos na extensão em que se propôs ${ }^{360}$, que era impedir o acúmulo de perdas (lucros cessantes). Consoante visto no Capítulo anterior, na coexistência de medidas onerosas com total eficiência, o credor deverá ser indenizado na extensão da medida não onerosa e não perigosa, além dos danos inevitáveis ${ }^{361}$.

Ora, ficou constatado aqui que a medida não onerosa e não perigosa era a compra imediata de uma nova máquina, pois o gasto seria de somente R \$3.100,00. Assim, este teria que ser o valor da indenização, arcando a autora com as despesas do conserto, frete e com as perdas decorrentes dos lucros cessantes. As referidas despesas com conserto e frete se mostraram ineficientes para a mitigação do prejuízo e, por isso, não deveriam ser indenizadas.

Outro equívoco consiste na distribuição do ônus da prova: consta no acórdão que o autor deveria ter provado que não tinha como adotar outras medidas razoáveis. Contudo, consoante já estudado no Capítulo 3, item 3.3., o ônus desta prova cabe ao réu. Portanto, a decisão acertou ao aplicar o duty to mitigate the loss, mas se equivocou em seus caracteres.

No tocante ao equívoco na aferição do quantum indenizatório, decisão semelhante foi proferida pelo Tribunal de Justiça do Estado do Piauí ${ }^{362}$, em caso que houve vazamento de combustível no equipamento fornecido pela ré ao autor, dono de um posto de gasolina. O autor não adotou nenhuma medida razoável para acabar com o vazamento por um longo período de tempo, levando à redução do valor de sua indenização. O Tribunal, igualmente, se equivocou no cálculo do ressarcimento devido: dos 43 meses em que houve o vazamento, somente foram descontados seis meses da indenização - sem qualquer justificativa -, sendo que desde logo o autor tinha ciência da perda de combustível e só informou a ré após dois anos. Assim, deveria ter descontado de sua indenização 24 meses.

\footnotetext{
${ }^{360}$ Vide a respeito, neste mesmo Título, o Capítulo 4, item 4.2.2.1., supra.

${ }^{361}$ Vide apêndice do Capítulo anterior.

${ }^{362}$ BRASIL. Tribunal de Justiça do Estado do Piauí, 1a Câmara Especializada Cível. Apelação Cível $n^{\circ}$ 2012.0001.002277-0. Apelantes/Apelados: Posto Ladeira do Uruguai Ltda. e Ipiranga Produtos de Petróleo S/A. Rel. Des. Raimundo Eufrásio Alves Filho, votação unânime, j. 28/11/2012.
} 


\subsubsection{Duty to mitigate the loss e dever de informação no processo ${ }^{363}$}

O caso deriva de outro processo. Em certa execução de particular, foram opostos embargos pelo Estado do Paraná para extinguir o feito. Na sentença deste, o pedido deduzido pelo Estado do Paraná foi julgado improcedente. Ocorre que, na súmula da sentença, constou condenação por litigância de má-fé, o que de fato não existia na decisão. Foram então opostos embargos de declaração sobre o conteúdo da sentença, mas em nada foi versado acerca da litigância de má-fé.

O procurador do Estado do Paraná, então, propôs ação de indenização por danos morais em face da escrivã da Vara de onde adveio a sentença, aduzindo que a publicação errada da súmula lhe causou diversos e graves danos. Tanto a primeira instância quanto a segunda julgaram improcedentes os pedidos, não reconhecendo haver dano moral indenizável. Inconformado, o autor interpôs recurso especial.

A Turma não deu provimento ao recurso, afirmando que, embora se reconheça a responsabilidade dos servidores públicos pelos seus atos, não houve abalo moral grave o bastante para originar um direito à indenização, principalmente porque a condenação por litigância de má-fé é voltada à parte, e não ao seu procurador. Deixou consignado que os erros de publicação são comuns, dado volume de ações que tramitam perante o Poder Judiciário. Além disso, o autor não observou o duty to mitigate the loss, haja vista que da publicação incorreta da súmula da sentença, não foi interposto qualquer recurso para sua correção. Se assim tivesse procedido, não teria sofrido os alegados prejuízos.

A aplicação do duty to mitigate the loss, no caso, está parcialmente correta. De fato, dada a quantidade enorme de processos e sendo corriqueiros os erros em publicações, não tinha como a servidora pública ter conhecimento de que a litigância de má-fé foi colocada de maneira equívoca na ementa. Cabia ao autor informar sobre o equívoco para que houvesse sua devida correção. Esta seria, portanto, a medida razoável.

Contudo, com a propositura da ação indenizatória por danos morais, o autor optou pela medida adequada e não perigosa, porém onerosa, já que teve gastos com custas processuais e honorários advocatícios, quando poderia, simplesmente, opor embargos de

\footnotetext{
363 BRASIL. Superior Tribunal de Justiça, 4 ${ }^{\mathrm{a}}$ Turma. Recurso Especial $\mathrm{n}^{\mathbf{o}}$ 1.325.862. Recorrente: Joel Samways Neto. Recorrido: Mara Regina de Oliveira Trevizan. Rel. Min. Luis Felipe Salomão, votação unânime, j. 05/09/2013.
} 
declaração ou apenas se dirigir ao cartório e requerer que fosse efetuada a devida correção. Os gastos foram evidentemente maiores e os ditos danos não foram mitigados.

O problema da decisão consiste na aplicação do duty to mitigate the loss como um mero reforço argumentativo, haja vista que a indenização pleiteada já estava afastada com o fato de o acórdão reconhecer que a litigância de má-fé se dirige à parte, e não ao procurador. Por isso, a invocação da norma de mitigação serviu somente para a análise de uma hipótese em que o autor realmente fosse atingido pela publicação errada.

Questão semelhante, quanto à ausência de observância do dever jurídico anexo de informação dentro do processo sobre fato relevante, é encontrada na jurisprudência do Tribunal do Estado de Santa Catarina ${ }^{364}$.

\subsection{Decisões com aplicação incorreta do duty to mitigate the loss}

\subsubsection{Duty to mitigate the loss e exercício tardio de um direito ${ }^{365}$}

A correntista e a instituição bancária celebraram contrato de abertura de crédito em conta corrente para a concessão de crédito rural para custeio e plantio. Litigam as partes acerca da previsão e aviso prévio da instituição financeira acerca da cobrança de encargos de manutenção, juros e tributos, afirmando a correntista que em nenhum momento a instituição financeira repassou esta informação. Além disso, também afirma que a instituição financeira não informou que era necessário o encerramento formal da conta bancária.

No julgamento, o Tribunal decidiu que a instituição financeira deveria ter avisado a correntista das pendências financeiras em sua conta corrente e que o valor cobrado se refere a serviços nunca prestados. A inércia da instituição financeira de cobrar desde logo a dívida é contrária ao duty to mitigate the loss, já que não estaria autorizada a permitir que a dívida se acumule demasiadamente e depois venha cobrar valores altíssimos.

\footnotetext{
${ }^{364}$ BRASIL. Tribunal de Justiça do Estado de Santa Catarina, $3^{\mathrm{a}}$ Câmara de Direito Civil. Apelação Cível no 2011.030785-0. Apelante: Rosa Maria Tesser. Apelada: Banco do Brasil S/A. Rel. Des. Maria do Rocio Luz Santa Ritta, votação unânime, j. 17/07/2012.

${ }^{365}$ BRASIL. Tribunal de Justiça do Estado de São Paulo, $19^{a}$ Câmara de Direito Privado, Apelação Cível $n^{\circ}$ 0000641-30.2004.8.26.0072. Apelantes/Apelados: Maria Elzy Caldeira Carvalho e Banco do Brasil S/A. Rel. Des. Ricardo Negrão, votação unânime, j. 04/03/2013.
} 
A aplicação do duty to mitigate the loss na decisão foi feita de forma equivocada. Consoante visto no Título II, Capítulo 2, item 2.3.3., o exercício tardio de um direito não se apresenta, por si só, como uma conduta contrária à boa-fé. O credor tem todo o prazo prescricional para exigir do devedor a dívida. Exigir no início ou ao final, em uma análise exclusiva, não é indício de boa-fé ou má-fé, respectivamente. É interesse do devedor de quitar seu débito para que os encargos incidentes não se acumulem.

Assim, o caso concreto teria que ter sido resolvido por outro viés: pela inobservância do dever jurídico anexo de informação pela instituição financeira e pela ilegalidade, em confronto com o Código de Defesa do Consumidor, da cobrança dos encargos de manutenção, juros e tributos não contratados.

Quanto ao exercício tardio de um direito, no Tribunal de Justiça do Estado do Espírito Santo também foram encontradas decisões semelhantes ${ }^{366}$, assim como no Tribunal de Justiça do Estado de Pernambuco ${ }^{367}$, no Tribunal de Justiça do Estado do Paraná $^{368}$ e no Tribunal de Justiça do Estado de Minas Gerais ${ }^{369}$. No tocante à invocação do duty to mitigate the loss ao invés da inobservância do dever de informação, foi encontrada decisão parecida no Tribunal de Justiça do Estado de Santa Catarina ${ }^{370}$.

\footnotetext{
366 BRASIL. Tribunal de Justiça do Estado do Espírito Santo, 4ª Câmara Cível. Apelação no 24060084241. Apelante: União de Professores Ltda. Apelada: Maria dos Anjos Herzog de Moraes. Rel. Des. Catharia Maria Novaes Barcellos, votação unânime, j. 10/03/2009; BRASIL. Tribunal de Justiça do Estado do Espírito Santo, $4^{a}$ Câmara Cível. Apelação no 24050215359. Apelante: Neusa Araujo Guimarães Lopes. Apelado: Centro Educacional Charles Darwin Ltda. Rel. Des. Catharia Maria Novaes Barcellos, votação unânime, j. 19/06/2007.

367 BRASIL. Tribunal de Justiça do Estado de Pernambuco, 1a Câmara Cível. Apelação no $275195-9$. Apelante: Associação Recifense de Educação e Cultura. Apelado: Banco Santander S/A. Rel. Des. Roberto da Silva Maia, votação unânime, j. 08/10/2013.

368 BRASIL. Tribunal de Justiça do Estado do Paraná, 15ª Câmara Cível. Apelação Cível no 755934-0. Apelantes/Apelados: Cooperativa de Crédito de Livre Admissão Maringá e Prestação de Serviços Radiológicos - TEC Imagem S/C. Rel. Des. Jucimar Novochadlo, votação unânime, j. 23/03/2011.

${ }^{369}$ BRASIL. Tribunal de Justiça de Minas Gerais, 14 ${ }^{\mathrm{a}}$ Câmara Cível. Apelação Cível n ${ }^{\circ}$ 1.0701.09.2877029/001. Apelante: Ismar Marcelino da Silva e outros. Apelado: Construtora Brilhante Ltda. Rel. Des. Rogério Medeiros, votação unânime, j. 09/02/2012.

${ }^{370}$ BRASIL. Tribunal de Justiça do Estado de Santa Catarina, $1^{\text {a }}$ Turma de Recursos - Capital. Recurso Inominado $n^{\circ}$ 2012.100782-0. Recorrente: Brasil Telecom S/A. Recorrida: Maria Goreti da Silva Vieira. Rel. Des. Margani de Mello, votação unânime, j. 07/02/2013.
} 


\subsubsection{Duty to mitigate the loss como fator de redução dos danos morais in re ipsa $a^{371}$}

A empresa apelante foi cobrada pela apelada por débito que aquela dizia inexistir. Inconformada com a cobrança indevida, a apelante propôs ação declaratória de inexistência de débito cumulada com indenizatória por danos morais. Em primeira instância, foi reconhecida a inexistência do débito, bem como houve condenação por danos morais. A autora, contudo, não se deu por satisfeita e pleiteou a majoração do valor da indenização.

O Tribunal não deu provimento ao recurso, sob o argumento de que o dano moral não se presta ao enriquecimento sem causa, devendo observar a dimensão do dano e a capacidade econômica das partes. Invocou o duty to mitigate the loss como meio de mensuração do dano moral: como a apelante não buscou soluções extrajudiciais para a resolução do conflito, logo ela não mitigou seu prejuízo.

A aplicação do duty to mitigate the loss neste caso é claramente equívoca. Os danos morais fixados por causa da negativação indevida do nome são danos considerados in re ipsa e, por este motivo, são devidos pela mera inclusão no cadastro, independentemente da produção de outras provas. Por se tratar de indenização por este único motivo, não importa a conduta do consumidor negativado, isto é, se ele não procurou solucionar o problema extrajudicialmente ou se demorou em tomar as providências cabíveis.

Descabe, então, limitar o valor indenizatório através do duty to mitigate the loss, já que se estaria realizando uma análise de motivos estranhos ao fato de o nome do consumidor ser incluído indevidamente no cadastro de inadimplentes. Só haveria esta discussão caso fossem pleiteadas perdas e danos decorrentes da negativação além da indenização pelo cadastro, já que diriam respeito a consequências gravosas da conduta ilícita do fornecedor.

Ademais, a norma de mitigação não serve simplesmente para mensurar o quantum indenizatório, mas também para, principalmente, incumbir o credor do ônus de razoavelmente evitar ou minimizar seu prejuízo. Na cobrança indevida, não havia como a apelante efetivamente mitigar seu dano, haja vista que se trata de abstenção de cobrança que só a própria apelada poderia realizar. Neste sentido, só há falar em inobservância dos

371 BRASIL. Tribunal de Justiça do Estado do Mato Grosso do Sul, $3^{\text {a }}$ Turma Cível. Apelação $n^{\circ}$ 2009.001940-8/0000-00. Apelante: Segurança Adm. e Corretora de Seguros Ltda. Apelada: Vivo S.A. Rel. Des. Fernando Mauro Moreira Marinho, votação unânime, j. 24/04/2007. 
deveres jurídicos anexos de informação e cooperação ${ }^{372}$ que poderiam, dado o caso concreto, minorar o valor da indenização pelo dano moral.

Aplicando a regra de aferição da razoabilidade, a mensuração do quantum indenizatório só é realizada na sua segunda parte e como terceiro estágio (eficiência da medida), depois de superadas as verificações de adequação, periculosidade e onerosidade. No caso, nem ao menos houve esta análise, pois o duty to mitigate the loss foi usado como simples critério de fixação do dano moral, assim como tantos outros existentes ${ }^{373}$. Por todos estes motivos, não se considera correta a aplicação da norma de mitigação neste julgado.

\subsubsection{Duty to mitigate the loss como mitigação do prejuízo alheio ${ }^{374}$}

Em setembro de 2007, a autora adquiriu de operadora de turismo da ré passagens para Maceió, ocorrendo atrasos e percalços que ensejaram aborrecimentos e a perda de dois dias de suas férias. Inconformada, propôs ação de indenização por danos morais. Em sentença, o juiz julgou a demanda improcedente, o que ensejou a interposição de recurso de apelação.

O Tribunal então deu provimento parcial à demanda, condenando a ré ao pagamento de indenização por danos morais. Quanto ao valor da indenização, foi invocado o duty to mitigate the loss para reduzi-lo, tendo em vista que a ré ofereceu shows, passeios e refeições à autora como forma de compensar pelos dissabores experimentados.

A norma de mitigação no caso foi aplicada de forma equivocada. Afinal, ela existe para atribuir um ônus ao credor de mitigar os seus próprios prejuízos, e não alheios. O que aconteceu no caso foi que a mitigação ocorreu pelo devedor em favor do credor, e não do credor em favor dele si próprio. Ao oferecer vantagens à autora, o credor tentou evitar ou minimizar o dano moral desta decorrente de seu inadimplemento (o atraso da viagem), o que não se coaduna com o que foi estudado até aqui acerca do duty to mitigate the loss.

\footnotetext{
${ }^{372}$ Vide Título I, Capítulo 2, itens 2.1.1.2.4. e 2.1.1.2.5.

${ }^{373}$ Vide, a respeito, Título II, Capítulo 2, item 2.3.7., supra.

374 BRASIL. Tribunal de Justiça do Estado do Rio Grande do Sul, 12a Câmara Cível. Apelação Cível $n^{\circ}$ 7002.813.8113. Apelante: Elida Rosa Dutra Guzenski. Apelada: BRA - Transportes Aéreos S.A. Rel. Des. Umberto Guaspari Sudbrack, votação unânime, j. 13/02/2009.
} 
Foi encontrada também outra decisão, no Tribunal de Justiça do Estado de Roraima, com entendimento semelhante ${ }^{375}$. No Tribunal de Justiça do Estado de Minas Gerais, são encontrados dois julgados ${ }^{376}$ que aplicam o duty to mitigate the loss no caso de o credor se recusar a emitir boleto antecipadamente para pagamento da dívida. Então, invocando o "dever" de o credor mitigar o prejuízo do devedor, foi mantida multa para cumprimento da obrigação.

\subsubsection{Duty to mitigate the loss como brocardo jurídico e dever de alegações processuais $^{377}$}

Os autores, ora agravantes, propuseram ação de execução acerca de dívida não quitada pelos fiadores em razão de locação comercial. Alegam que os fiadores realizaram doação inoficiosa de imóvel após a propositura da ação de execução, o que poderia configurar fraude contra a execução já que a demanda seria capaz de levar os executados à insolvência. O juiz de primeira instância negou a existência de fraude contra credores, afirmando que somente os herdeiros eventualmente preteridos poderiam pleitear a anulação da doação. Desta decisão os autores interpuseram o recurso de agravo de instrumento.

Os desembargadores não deram provimento ao recurso, afirmando que, ao contrário do afirmado pelos agravantes, a doação foi realizada antes da propositura da ação de execução e, por isso, poderia configurar fraude contra credores. No entanto, com a falta de elementos suficientes, não seria possível se aprofundar na análise da configuração da fraude contra credores ou não. Ademais, ratificaram o entendimento do juízo de primeira instância de serem legítimos apenas os herdeiros preteridos para pleitear a anulação da doação. Por fim, ressaltaram que caso um dos terrenos informados nos autos não seja

\footnotetext{
${ }^{375}$ BRASIL. Tribunal de Justiça do Estado de Roraima, Câmara Única - Turma Cível. Apelação Cível no 0010.10.910849-7. Apelante: G. R. F. Apelado: E. C. J. Rel. Des. Almiro Padilha, votação unânime, j. $17 / 12 / 2013$.

376 BRASIL. Tribunal de Justiça de Minas Gerais, $12^{\mathrm{a}}$ Câmara Cível. Agravo de Instrumento $\mathrm{n}^{\circ}$ 1.0024.12.270283-0/001. Agravante: Lucas Antonio de Assis. Agravado: Banco Semear S/A. Rel. Des. Domingos Coelho, votação unânime, j. 12/12/2012; BRASIL. Tribunal de Justiça de Minas Gerais, $12^{\mathrm{a}}$ Câmara Cível. Agravo de Instrumento no 1.0702.11.024301-2/001. Agravante: Banco Itaú S/A. Agravado: João Dorneles dos Santos Dias. Rel. Des. José Flávio de Almeida, votação unânime, j. 14/09/2011.

377 BRASIL. Tribunal de Justiça do Estado de São Paulo, $27^{\text {a }}$ Câmara de Direito Privado. Agravo de Instrumento ${ }^{\circ}$ 0266216-42.2012.8.26.0000. Agravantes: Imobiliária Plaza Ltda. e outro. Agravados: Djair Pirana e outra. Rel. Des. Campos Petroni, votação unânime, j. 16/04/2013.
} 
suficiente para saldar a dívida, que os agravantes poderiam insistir na tese da desconstituição da doação, cabendo ao caso o brocardo duty to mitigate the loss.

Não está correta a aplicação da norma de mitigação no caso. Em primeiro lugar, não se trata de um brocardo. Brocardos jurídicos, normalmente transcritos em latim, são máximas jurídicas, axiomas, pensamentos traduzidos e sintetizados em um provérbio, que resumem uma secular experiência jurídica. Tratam de uma sabedoria que nem sempre traduzem princípios gerais, mas trazem ideias diretoras de inegável valor prático ${ }^{378}$. Não possuem por si só força de lei, apesar de muitas vezes as legislações os adotarem expressamente, já que deles não há como se afastar.

Não é, contudo, o caso do duty to mitigate the loss. Não se trata de uma experiência jurídica secular, tanto que sua presença ainda é muito tímida nas legislações, bem como cercada de enormes controvérsias. Conforme visto no Título I, Capítulo 2, item 2.4., é uma expressão relativamente nova, em construção pelos operadores do Direito. Não se trata, igualmente, de um exclusivo referencial geral para o ordenamento jurídico, pois fundado no princípio da boa-fé, estes sim cristalizados historicamente como princípios gerais de direito desde o Digesto ${ }^{379}$.

Também é de se estranhar a invocação do duty to mitigate the loss no caso. Não apresenta qualquer relação com o caso concreto. $O$ que se pode imaginar é que o magistrado pretendeu avisar que a tese da desconstituição da doação é uma medida disponível aos autores para mitigarem seu prejuízo, ou seja, saldar a dívida diante da insuficiência dos demais bens penhoráveis.

Se esta for a intenção, trata-se de aplicação incorreta da norma de mitigação. Esta interpretação inverte o interesse jurídico das partes, já que onera o credor pela dívida contraída pelo devedor. O caso guarda semelhanças ao discutido no Título I, Capítulo 2, itens 2.3.3. e 2.3.3.1. sobre prescrição e supressio. A aptidão para a redução do prejuízo é do próprio devedor, já que o não pagamento da dívida o faz incorrer em correção monetária e demais encargos previstos na lei ou no contrato. Não são prejuízos não evitados pelo credor, mas prejuízos, próprios do devedor, que se originam a partir de seu inadimplemento.

\footnotetext{
${ }^{378}$ REALE, Miguel. Lições Preliminares de Direito. $29^{a}$ ed. São Paulo: Saraiva, 2001. p. 320-321.

379 "Fides bona contraria est fraudi et dolo" (D.1.3.3.17).
} 
Assim, não é porque o autor não tenta anular a doação que não estará cumprindo com o ônus de mitigação, agravando a situação do devedor. É interesse do devedor quitar a dívida para que a sua própria situação não se agrave.

\subsubsection{Aplicação do duty to mitigate the loss ao invés da culpa concorrente ${ }^{380}$}

Os autores, ora apelados, contrataram o réu, engenheiro, para a construção de uma piscina. No contrato celebrado, foi determinado que fosse pago o valor parcelado de $\mathrm{R} \$$ 20.500,00 pelo serviço e que seria realizado em até 75 dias, até 27/09/2004. Por conta de chuvas, da inadequação dos materiais comprados e de um vazamento sem causa esclarecida, a piscina não ficou pronta no prazo. Em 01/12/2004, os autores notificaram extrajudicialmente o réu que suspenderiam o pagamento das parcelas dos próximos seis meses. Além disso, impediram que o réu tivesse acesso a obra e descobrisse o motivo do vazamento.

Pelos danos e dissabores sofridos, os autores propuseram ação indenizatória cobrando tanto danos materiais quanto morais. Após a sentença de procedência em primeira instância, o réu interpôs recurso de apelação.

No acórdão, os desembargadores deram parcial provimento ao recurso, salientando que os autores também tiveram participação na ocorrência do dano ao impedir o acesso do réu na obra, na rápida contratação de advogado para a notificação extrajudicial e nas cláusulas contratuais acerca da forma de pagamento, que faziam com que somente $15 \%$ do valor fosse pago até a entrega da piscina. Todas estas atitudes contrariaram a boa-fé e, pelo sopesamento de culpas e à luz do duty to mitigate the loss, os autores tiveram o seu valor indenizatório por danos materiais reduzido e por danos morais excluído.

Não se trata, aqui, de uma correta aplicação do duty to mitigate the loss. O caso se resolve verdadeiramente através da responsabilidade civil, pelo uso da culpa concorrente, haja vista que não haveria mitigação dos prejuízos decorrentes do inadimplemento, mas participação culposa da vítima na própria produção do inadimplemento. Inclusive, o próprio acórdão menciona o sopesamento de culpas, o que evidencia ainda mais que não se

\footnotetext{
380 BRASIL. Tribunal de Justiça do Estado de São Paulo, 34 Câmara de Direito Privado. Apelação Cível com Revisão no 1036109-0/8. Apelante: Emersson Clássere. Apelado: Antônio Carlos Pereira e outros. Rel. Des. Rosa Maria de Andrade Nery, votação unânime, j. 27/06/2007.
} 
está diante do duty to mitigate the loss. Então, a redução da indenização se deu pela análise do nexo causal, da participação tanto dos autores-vítimas quanto do réu no descumprimento dos termos contratuais de construção da piscina.

\subsubsection{Aplicação do duty to mitigate the loss ao invés da culpa exclusiva da vítima ${ }^{381}$}

O autor da ação é correntista do banco, ora réu. Em certa data, dirigiu-se a um caixa eletrônico para sacar determinada quantia de dinheiro, mas o seu cartão ficou retido no equipamento. Sem conseguir retirá-lo e sem conseguir qualquer contato com a central de atendimento do réu, o autor se retirou do local e foi viajar. Quando retornou dez dias depois, foi surpreendido com diversos saques indevidos na sua conta bancária. Diante da situação, formalizou um Boletim de Ocorrência e informou o réu dos saques indevidos.

Diante deste panorama, propôs ação indenizatória pleiteando os valores sacados ilegalmente além de danos morais. Em primeira instância, a ação foi julgada parcialmente procedente, acolhendo somente os danos materiais. $\mathrm{O}$ réu, inconformado com a condenação, interpôs recurso de apelação pedindo a reforma da sentença.

Em segunda instância, o recurso foi provido, sob o argumento de que o autor não conseguiu provar a culpa do réu. Ademais, ficou evidenciada no caso a culpa exclusiva da vítima e, pelo duty to mitigate the loss, o autor tinha que mitigar seu prejuízo não se omitindo. Ademais, foi considerado, diante da estranheza do caso e da postura do autor, que os saques não foram indevidos.

Neste caso, o duty to mitigate the loss não deveria ter sido invocado, tendo em vista que a questão se resolveria simplesmente com a aplicação da responsabilidade civil através da culpa exclusiva da vítima ${ }^{382}$. O dano sofrido pelo autor em nada tem relação com a postura do réu. Inexistem inadimplemento e prejuízo imputável ao devedor, dois dos pressupostos de existência da norma de mitigação.

\footnotetext{
${ }^{381}$ BRASIL. Tribunal de Justiça do Estado do Rio Grande do Sul, 17 $7^{\text {a }}$ Câmara Cível. Apelação Cível no 70032014458. Apelante: Banco do Estado de São Paulo S/A. Apelado: Moacir Sylvio Dal Castel. Rel. Des. Liége Puricelli Pires, votação unânime, j. 12/11/2009.

${ }^{382}$ A respeito, vide Título II, Capítulo 3, item 3.2.2.2.1., supra.
} 


\subsubsection{Cláusula penal e aplicação do duty to mitigate the loss como sinônimo de supressio e venire contra factum proprium ${ }^{383}$}

As partes celebraram contrato de fornecimento de combustíveis e comodato de equipamentos, estabelecendo no caso de descumprimento uma cláusula penal. Os réus, ora apelantes, se tornaram inadimplentes, deixando de pagar a quantia devida. Após um ano de inadimplemento e criando a confiança legítima de que não cobraria os valores devidos, o autor propôs ação de rescisão contratual cumulada com indenização por perdas e danos, danos morais por usurpação de marca e reintegração de posse. A ação foi julgada parcialmente procedente em primeira instância, ensejando a interposição de recurso de apelação pelos réus.

O Tribunal então deu parcial provimento ao recurso, apenas para modificar a fixação da multa prevista na cláusula penal, que ultrapassava $10 \%$ do período de inadimplência não tolerado pelos autores e que a indenização de $50 \%$ da margem de lucro só poderia incidir por este período. Justificou também que a ausência de cobrança durante um ano criou a expectativa legítima para os réus que a dívida não seria mais exigida, o que contraria o princípio da boa-fé objetiva, na sua derivação, o "princípio" e "dever jurídico anexo" do duty to mitigate the loss. Este desrespeito à mitigação demonstrou deslealdade dos autores, o que evidencia violação à supressio e ao venire contra factum proprium.

A decisão está incorreta em sua aplicação do duty to mititgate the loss. Em primeiro lugar, consoante já estudado no Título I, Capítulo 2, item 2.1.1.3.1., a norma de mitigação não se constitui um princípio autônomo, tampouco um dever jurídico anexo ao princípio da boa-fé. Trata-se de um ônus derivado da boa-fé o qual incumbe o credor mitigar seus próprios prejuízos.

Em segundo lugar, conforme visto no Título I, Capítulo 2, item 2.3.1., na presença de uma cláusula penal não há espaço para discussão acerca do duty to mitigate the loss. Isto porque as partes antecipadamente renunciam ao seu poder de liquidar o prejuízo no caso de inadimplemento, já prevendo o montante que será suficiente para ressarci-las das perdas e danos. Não há no acórdão qualquer referência à cláusula de indenização

\footnotetext{
${ }^{383}$ BRASIL. Tribunal de Justiça do Estado de São Paulo, $16^{\text {a }}$ Câmara de Direito Privado. Apelação Cível no 1.170.013-1. Apelantes: Auto Posto Shopping Diadema Ltda. e outros. Apelada: Mercoil Distribuidora de Petróleo Ltda. Rel. Des. Windor Santos, votação por maioria, j. 03/07/2007.
} 
suplementar, então, reputa-se como equivocada a decisão ao analisar o duty to mitigate the loss neste ponto.

Em terceiro lugar, o acórdão trata a norma de mitigação como um mero aspecto do venire contra factum proprium e da supressio. Como analisado no Título I, Capítulo 2, itens 2.2.1. e 2.3.3.1., tratam-se de institutos distintos. Tanto o venire contra factum proprium quanto a supressio protegem a confiança legítima criada pelo credor de que não cobraria a dívida, enquanto que o duty to mitigate the loss delimita a extensão do direito subjetivo das partes. Não há, na norma de mitigação, um ato lícito seguido de um ilícito como ocorre nos outros dois institutos, pois a disposição do próprio patrimônio não é vedado pelo ordenamento jurídico, mas tem como consequência a vedação de ressarcimento pelos prejuízos evitáveis não mitigados.

No Tribunal de Justiça do Estado do Espírito Santo ${ }^{384}$ e no Tribunal de Justiça do Estado do Rio de Janeiro ${ }^{385}$ também são encontradas decisões que assumem o duty to mitigate the loss como sinônimo de venire contra factum proprium.

\subsubsection{Duty to mitigate the loss, dever de informação e renúncia de direito ${ }^{386}$}

O autor, ora apelado, foi vítima de saques indevidos na sua conta bancária da ré. Após informar a ré do fato, esta abriu procedimento administrativo para apuração e, após dezoito dias, constatou realmente o autor ter sido vítima de fraude. Disponibilizou a ele, então, a quantia indevidamente sacada de sua conta, só que para tanto deveria assinar um termo para a continuidade das investigações, o que implicaria na quebra de seu sigilo bancário. $\mathrm{O}$ autor se negou a assinar referido termo, alegando ser inconstitucional a quebra de seu sigilo sem ser por autorização judicial e que a investigação seria realizada por autoridade incompetente. Inconformado, propôs ação de indenização por danos materiais, pleiteando o valor objeto de fraude e danos morais.

\footnotetext{
${ }^{384}$ BRASIL. Tribunal de Justiça do Estado do Espírito Santo, $2^{\mathrm{a}}$ Câmara Cível. Agravo de Instrumento $\mathrm{n}^{\circ}$ 24139022149. Agravante: Vila Real Serviços Especializados Ltda. ME. Agravada: Casa e Café Assessoria Profissional Ltda. ME. Rel. Des. José Paulo Calmon Nogueira da Gama, decisão monocrática, j. 04/12/2013. 385 BRASIL. Tribunal de Justiça do Estado do Rio de Janeiro, 9a Câmara Cível. Apelação $\mathrm{n}^{\circ}$ 000097675.2003.8.19.0073. Apelantes/Apelados: Carlos Augusto Lopes da Silva e Francisco Cesar de Azevedo. Rel. Des. Roberto de Abreu e Silva, decisão monocrática, j. 05/08/2013.

${ }^{386}$ BRASIL. Tribunal Regional Federal da $5^{\mathrm{a}}$ Região, $3^{\mathrm{a}}$ Turma. Apelação Cível no 2003.83.00.022344-0. Apelante: Caixa Econômica Federal. Apelado: Flávio Pereira do Amaral. Rel. Des. Leonardo Resende Martins, votação unânime, j. 03/09/2009.
} 
A ação foi julgada parcialmente procedente na primeira instância, o que ensejou recurso de apelação por parte da ré. Em segunda instância, o recurso foi parcialmente provido, excluindo a condenação por danos morais.

Decidiram os desembargadores que não havia dúvidas quanto à responsabilidade da ré de devolver o montante objeto de fraude, mas a postura do autor de não querer assinar o termo e resolver com celeridade o problema não autorizavam a condenação por danos morais. Ao negar a imediata solução para tentar uma ação de indenização por danos morais, o autor agiu contrariamente à boa-fé, sobretudo ao duty to mitigate the loss.

A aplicação da norma de mitigação, no caso, está incorreta. Afinal, penalizou o autor que foi vítima de uma fraude bancária pelo simples motivo de não ter aceitado renunciar ao seu sigilo bancário e ao seu direito de propor ação indenizatória por danos morais, ambos protegidos constitucionalmente.

E a devolução dos valores subtraídos nem ao menos poderia e precisaria estar atrelada à assinatura do termo, tendo em vista que eles puderam ser restituídos judicialmente, sem necessidade de qualquer quebra de sigilo bancário. A investigação é ônus próprio da instituição financeira e se seus sistemas de segurança são falíveis, não se pode penalizar o correntista pela violação de seus direitos. Neste diapasão, não faz sentido invocar o duty to mitigate the loss para restringir a indenização do autor.

Estaria correta a aplicação do duty to mitigate the loss, todavia, se tivesse sido invocado para fundamentar a restituição dos valores objetos de fraude. O autor, assim que constatou os saques irregulares, entrou em contato com a ré. Praticou, portanto, uma medida razoável: adequada por ser uma solução viável para a restituição de seu dinheiro, não perigosa porque não envolveu risco de vida e não onerosa porque não realizou qualquer despesa - ou ao menos, que apresentasse qualquer relevância - para informar a ré dos fatos. Como a ré não tinha como ter ciência prévia dos saques indevidos, a postura do autor foi decisiva e considerável como uma medida razoável de mitigação. Tratava-se, neste escopo, de um prejuízo evitável Merecia, então, ser ressarcido do valor subtraído de sua conta bancária. 


\subsubsection{Aplicação do duty to mitigate the loss ao invés da violação ao dever de informação $^{387}$}

O réu sofreu acidente automobilístico e ficou internado em um hospital, autor da ação. Foram realizados diversos procedimentos e utilizados diversos recursos do hospital para tanto, sendo que tudo foi formalizado mediante autorização genérica de realização de procedimentos. Nela não havia a informação de cobrança dos valores, tampouco a opção do réu utilizar os recursos gratuitos do Sistema Único de Saúde (SUS). Após a cura do paciente, o autor efetuou a cobrança extrajudicial do réu, que negou prontamente o seu pagamento. Não vendo alternativa, propôs ação de cobrança.

Em primeira instância, os pedidos de indenização foram julgados improcedentes. O autor, então, interpôs recurso de apelação pleiteando a integral reforma da sentença atacada. O réu interpôs recurso adesivo pleiteando aumento da verba honorária. O Tribunal negou provimento a ambos os recursos, ressaltando que o autor descumpriu com o duty to mitigate the loss ao não informar o réu dos valores dos procedimentos, o que caracterizaria, inclusive, afronta ao Código de Defesa do Consumidor.

A aplicação do duty to mitigate the loss no caso está incorreta, tendo em vista que não houve inobservância da mitigação dos prejuízos, e sim, do dever jurídico anexo de informação do princípio da boa-fé. A norma de mitigação incidiria no caso se o autor não adotasse alguma medida após o inadimplemento do réu que evitasse ou minimizasse eventuais prejuízos que surgissem, fato que não foi sequer cogitado nos autos. O problema surgiu na formação do contrato, já que o réu não teve ciência prévia de que seria cobrado pelos procedimentos realizados.

\footnotetext{
${ }^{387}$ BRASIL. Tribunal de Justiça do Estado de Santa Catarina, $5^{\text {a }}$ Câmara de Direito Civil. Apelação Cível no 2013.035089-5. Apelantes/Apelados: Sociedade Mãe da Divina Providência Hospital Nossa Senhora dos Prazeres e Edson Luiz Batista dos Santos. Rel. Des. airo Fernandes Gonçalves, votação unânime, j. 03/12/2013.
} 


\subsubsection{Cobrança indevida de tarifas bancárias e tributos incidentes em conta corrente inativa $^{388}$}

A autora, correntista da instituição financeira ré, manteve sua conta bancária inativa por longo período. Mesmo sem qualquer movimentação, o réu continuou a debitar mensalmente tarifas bancárias e tributos incidentes acerca dos serviços bancários disponibilizados, sem cobrar ou comunicar a autora do incremento do seu débito. Tendo atingido a dívida certo patamar, o réu registrou o nome da autora no cadastro de inadimplentes. Inconformada, a autora ingressou com ação de indenização por danos materiais, morais e pedindo a retirada de seu nome do cadastro.

Em primeira instância o pedido foi julgado improcedente, considerando a cobrança da dívida um exercício regular do direito do réu. A autora apelou da decisão, tendo decidido o desembargador em decisão monocrática dar provimento ao seu recurso, invocando o duty to mitigate the loss para justificar que o réu deveria ter mitigado seu prejuízo, não permitindo o débito acumular.

A decisão aplica equivocadamente a norma de mitigação, tendo em vista que se trata de violação aos deveres jurídicos anexos ao princípio da boa-fé de informação, cooperação e lealdade e não de inobservância do ônus de mitigação. Não se trata aqui de surgimento de prejuízos decorrentes do inadimplemento, mas meros desdobramentos do próprio contrato celebrado com a instituição bancária. Esta tinha que informar a correntista da existência das tarifas e encargos mensais e, posteriomente, da existência do débito e cobrá-la devidamente, e não deixar que a dívida aumentasse demasiadamente. Portanto, não faltou com o ônus da mitigação, mas com os deveres jurídicos anexos derivados do princípio da boa-fé.

No mesmo sentido foram encontradas outras decisões no mesmo Tribunal ${ }^{389}$, no Tribunal de Justiça do Estado do Espírito Santo ${ }^{390}$, no Tribunal de Justiça do Estado do Paraná $^{391}$ e no Tribunal de Justiça do Estado de São Paulo ${ }^{392}$.

\footnotetext{
${ }^{388}$ BRASIL. Tribunal de Justiça do Estado do Rio de Janeiro, $27^{\text {a }}$ Câmara Cível Consumidor. Apelação $\mathrm{n}^{\circ}$ 0392705-53.2011.8.19.0001. Apelante: Maria da Penha Duarte de Lima. Apelado: Itaú Unibanco S/A. Rel. Des. Marcos Alcino de Azevedo Torres, decisão monocrática, j. 31/01/2014.

389 BRASIL. Tribunal de Justiça do Estado do Rio de Janeiro, $19^{a}$ Câmara Cível. Apelação no 1639488 93.2011.8.19.0004. Apelante: Banco Santander Brasil S/A. Apelado: Otavio Junior Gomes Ribeiro. Rel. Des. Eduardo de Azevedo Paiva, decisão monocrática, j. 21/03/2013; BRASIL. Tribunal de Justiça do Estado do Rio de Janeiro, 9a Câmara Cível. Apelação Cível nº 0219297-89.2009.8.19.0001. Apelante: Cláudio César
} 


\section{TÍTULO III - O DUTY TO MITIGATE THE LOSS NO DIREITO \\ EXTERNO}

\section{O DUTY TO MITIGATE THE LOSS NA CONVENÇÃO DAS NAÇÕES UNIDAS SOBRE CONTRATOS DE COMPRA E VENDA INTERNACIONAL DE MERCADORIAS}

\subsection{Introdução}

A Convenção das Nações Unidas sobre Contratos de Compra e Venda Internacional de Mercadorias (CISG) é uma norma jurídica uniforme que visa regulamentar os contratos de compra e venda internacional de mercadorias dos países signatários. A Convenção foi preparada pela Comissão das Nações Unidas sobre o Direito do Comércio Internacional (UNCITRAL) e aprovada por uma conferência diplomática no dia 11 de abril de 1980.

A preparação da CISG iniciou-se em 1930 no Instituto Internacional para a Unificação do Direito Privado (UNIDROIT), em Roma, tendo os trabalhos sido interrompidos por um longo período por causa da Segunda Guerra Mundial. Em 1964, o esboço foi apresentado em uma conferência diplomática realizada em Haia, na qual foram aprovadas duas convenções: uma sobre contratos de compra e venda internacional de mercadorias e outra sobre a formação de contratos de compra e venda internacional de mercadorias.

As convenções, contudo, não foram bem aceitas, suscitando muitas críticas acerca de suas disposições, principalmente pelos Estados que não estavam alinhados com a tradição jurídica e a realidade econômica da Europa Ocidental. Assim, a partir de 1968 a UNCITRAL se dedicou a reunir as críticas e sugestões dos Estados, bem como verificar a

\footnotetext{
Maia de Bittencourt Lobo. Apelado: Banco Citibank S/A. Rel. Des. Roberto de Abreu e Silva, decisão monocrática, j. 28/09/2010.

${ }^{390}$ BRASIL. Tribunal de Justiça do Estado do Espírito Santo, 2ª Câmara Cível. Apelação no 38040012593. Apelante: Banestes S/A. Apelado: Espólio de Luciano Sélia. Rel. Des. José Paulo Calmon Nogueira da Gama, decisão monocrática, j. 02/02/2011.

391 BRASIL. Tribunal de Justiça do Estado do Paraná, 14 ${ }^{a}$ Câmara Cível. Apelação Cível no 1163274-3. Apelantes/Apelados: Paraná Banco S/A e Amaro Teofilo Monteiro. Rel. Des. Edgard Fernando Barbosa, votação unânime, j. 29/01/2014.

392 BRASIL. Tribunal de Justiça do Estado de São Paulo, 19a Câmara de Direito Privado. Apelação ${ }^{\circ}$ 991.07.072632-5. Apelante: José Motta. Apelado: Banco do Brasil S/A. Rel. Des. Ricardo Negrão, votação unânime, j. 19/10/2010.
} 
intenção de aderir às convenções caso as modificações em seus textos as tornariam mais suscetíveis de englobar diferentes sistemas jurídicos, sociais e econômicos. O resultado deste estudo foi a aprovação, em 11 de abril de 1980, da Convenção das Nações Unidas sobre Contratos de Compra e Venda Internacional de Mercadorias, a qual combina as matérias tratadas nas duas convenções anteriores.

A Convenção entrou em vigor em $1^{\circ}$ de janeiro de 1988 para os primeiros onze Estados signatários, com representantes de cada região geográfica, cada estágio de desenvolvimento econômico e cada principal sistema jurídico, social e econômico. Os primeiros onze Estados foram: Argentina, China, Egito, França, Hungria, Itália, Lesoto, Síria, Estados Unidos, Iugoslávia e Zâmbia ${ }^{393}$. Atualmente, aderiram à CISG oitenta Estados, inclusive o Brasil.

\subsection{Incorporação ao direito brasileiro}

O primeiro passo para a incorporação da CISG no direito brasileiro foi dado no dia 8 de maio de 2012, data em que a Câmara dos Deputados aprovou o seu texto. Alguns meses depois, mais precisamente em 16 de outubro de 2012, o Senado também o aprovou. Assim, na mesma data, o Congresso Nacional promulgou o Decreto Legislativo $\mathrm{n}^{\circ}$ 538/2012, tornando a CISG parte do ordenamento jurídico brasileiro. Isto porque, em se tratando de tratado internacional promulgado por decreto legislativo, o ingresso no ordenamento jurídico pátrio independe de sanção pelo Poder Executivo, conforme dispõe a Constituição Federal ${ }^{394}$. Em nível internacional, o instrumento de adesão foi depositado no dia 4 de março de 2013 junto ao Secretário-Geral da ONU, Ban Ki-moon, tornando-se o Brasil o $79^{\circ}$ Estado-Parte da Convenção ${ }^{395}$.

Em razão de não tratar de matéria de direitos humanos e, por isso, não ter sido aprovada pela maioria qualificada do artigo $5^{\circ}$, parágrafo $3^{\circ}$ da Constituição Federal, a

\footnotetext{
${ }^{393}$ UNCITRAL. Explanatory Note by the UNCITRAL Secretariat on the United Nations Convention on Contracts for the International Sale of Goods. Disponível em: http://www.cisg.law.pace.edu/cisg/text/p23.html. Acesso em: 21/03/2014.

${ }^{394}$ Art. 49. É da competência exclusiva do Congresso Nacional:

I - resolver definitivamente sobre tratados, acordos ou atos internacionais que acarretem encargos ou compromissos gravosos ao patrimônio nacional;

395 ORGANIZAÇÃO DAS NAÇÕES UNIDAS. Brasil adere à Convenção da ONU sobre contratos internacionais de compra e venda de mercadorias. 5 de março de 2013. Disponível em: http://www.onu.org.br/brasil-adere-a-convencao-da-onu-sobre-contratos-internacionais-de-compra-e-vendade-mercadorias/. Acesso em 21/03/2014.
} 
CISG não foi incorporada como emenda constitucional ou lei com status supralegal ${ }^{396}$. O seu nível hierárquico é o equivalente ao de uma lei ordinária.

Em tese, a CISG deveria começar a produzir efeitos a partir do dia primeiro de abril de 2014, já que, consoante dispõe o seu artigo 99 (2), a CISG só entrará em vigor para o Estado que a ela aderir no primeiro dia do mês seguinte ao término do prazo de doze meses, contado da data em que haja depositado seu instrumento de adesão. No entanto, até o momento não foi emitido um decreto presidencial de promulgação da CISG, ato final de todo o procedimento de incorporação de tratados internacionais no ordenamento jurídico brasileiro. Assim, a convenção ainda não produz qualquer efeito em território brasileiro.

De qualquer maneira, considerando que em breve a CISG terá efiácia no direito pátrio e consoante se verá no item seguinte, este tratado internacional foi o segundo diploma legal a trazer dispositivos específicos sobre o duty to mitigate the loss no ordenamento jurídico pátrio, sendo o primeiro o próprio Código Civil nas regras próprias do contrato de seguro ${ }^{397}$. É o primeiro, no entanto, a tratar do tema com tanta evidência, especificamente nos contratos de compra e venda internacional de mercadorias.

\subsection{O artigo 77 da CISG}

A CISG traz dispositivo específico acerca do duty to mitigate the loss, inserido na Seção II do Capítulo V que trata das perdas e danos. Um detalhe importante que merece ser mencionado é que a CISG não obriga a parte a adotar uma medida específica no caso de haver alguma crise no negócio jurídico pactuado. Na verdade, a conversão em perdas e danos é apenas uma das opções disponíveis tanto para o comprador quanto para o devedor, que poderá, por exemplo, exigir que o inadimplemento seja sanado (artigos 47, 48 e 63), declarar resolvido o contrato (artigos 49 e 64), etc. No entanto, havendo a conversão em perdas e danos, recairá a norma do artigo 77, que assim dispõe:

\footnotetext{
${ }^{396} \mathrm{O}$ modelo da supralegalidade de tratados internacionais que versam sobre direitos humanos, mas não aprovados pela maioria qualificada no Congresso Nacional foi adotada a partir do julgamento do Recurso Extraordinário $\mathrm{n}^{\circ} 466.343$ pelo Supremo Tribunal Federal. Em apertada síntese, a ideia é que como são tratados que dispõem sobre uma matéria de suma relevância devem ser situados em posição intermediária que permita qualificá-los como diplomas impregnados de estatura superior à das leis internas em geral, ainda que submetidos à Constituição Federal.

${ }^{397}$ Vide Título I, Capítulo 2, item 2.3.5 supra.
} 


\begin{abstract}
Artigo 77
A parte que invocar o inadimplemento do contrato deverá tomar as medidas que forem razoáveis, de acordo com as circunstâncias, para diminuir os prejuízos resultantes do descumprimento, incluídos os lucros cessantes. Caso não adote estas medidas, a outra parte poderá pedir redução na indenização das perdas e danos, no montante da perda que deveria ter sido mitigada.
\end{abstract}

A norma possui duas partes. A primeira trata da incumbência que a parte possui de tomar as medidas razoáveis para diminuir os prejuízos decorrentes do inadimplemento da outra. A segunda trata das consequências do descumprimento da mitigação nos termos estabelecidos na primeira parte: a redução da indenização por perdas e danos no montante da perda que deveria ter sido objeto de mitigação. Passa-se a analisar as partes do artigo 77 separadamente.

Destaca-se na primeira parte a necessidade de a vítima do inadimplemento tomar alguma medida para a diminuição de seu prejuízo e que esta medida seja razoável. A CISG se utiliza do vocábulo "deverá”, o que poderia suscitar que a natureza jurídica da norma de mitigação é de um dever jurídico. Contudo, mesmo no esboço de 1978 da CISG já não se considerava o dever prescrito no artigo 77 com a mesma natureza dos demais deveres presentes no tratado ${ }^{398}$. E a doutrina sobre o tema também reconhece que não se pode atribuir a natureza de dever para a norma de mitigação, de igual maneira que ocorre no direito inglês ${ }^{399}$. Tal conclusão vai ao encontro do que foi defendido neste estudo, compreendendo o duty to mitigate the loss como um ônus, e não um dever ${ }^{400}$.

Consoante defende Knapp ${ }^{401}$, o artigo 77 da CISG é decorrência do princípio da prevenção, o qual obriga que a parte na iminência de ser prejudicada com um inadimplemento contratual tome medidas para reduzir seu prejuízo. Não permite, então, que a parte prejudicada espere pacientemente a ocorrência do dano para depois propor ação indenizatória. No direito interno, não se fala em um princípio da prevenção próprio do direito contratual, mas a proteção que pretenderia regulamentar é decorrente do princípio

\footnotetext{
398 CHENGWEI, Liu. Remedies for Non-performance: Perspectives from CISG, UNIDROIT Principles \& PECL. Setembro de 2003. Disponível em: http://www.cisg.law.pace.edu/cisg/biblio/chengwei-77.html. Acesso em 07/02/2014.

399 SAIDOV, Djakhongir. Methods of Limiting Damages under the Vienna Convention on Contracts for the International Sale of Goods. Dezembro de 2001. Disponível em: http://cisgw3.law.pace.edu/cisg/biblio/saidov.html. Acesso em 07/02/2014.

${ }^{400}$ Vide Título I, Capítulo 2, item 2.1.1.3.1., supra.

${ }^{401}$ KNAPP, Victor. Bianca-Bonell Commentary on the International Sales Law. Giuffrè: Milan, 1987. p. 559-567. Disponível em: http://www.cisg.law.pace.edu/cisg/biblio/knapp-bb77.html. Acesso em 07/02/2014.
} 
da boa-fé. Logo, para fins de recepção no ordenamento jurídico pátrio, não é preciso recorrer a um novo princípio, mas aprofundar a análise dos desdobramentos da boa-fé ${ }^{402}$.

O dispositivo faz referência às medidas razoáveis a serem tomadas pela parte prejudicada, conforme as circunstâncias do caso. Assim como muitas legislações fazem, o preenchimento do significado do que seria razoável fica a cargo da hipótese fática, sem trazer um conteúdo definido. Chengwei, apoiando-se na lei europeia de princípios contratuais (Principles of European Contract Law - PECL), traduz a razoabilidade como levar em consideração a natureza e propósito do contrato, as circunstâncias do caso, usos e práticas do comércio ou da profissão envolvidos ${ }^{403}$. É, também o que está disposto no artigo $8^{\circ}$ da CISG. Consoante as assertivas trazidas neste estudo, nota-se que o critério é insuficiente, pois delega toda a análise da incidência da mitigação para o casuísmo, sem trazer um modelo de aferição da razoabilidade que traga ao menos uma certa previsibilidade, característica ínsita de um ordenamento jurídico. Posiciona-se, portanto, pela prevalência da regra de aferição de razoabilidade aqui desenvolvida, por trazer maior segurança jurídica às partes quando submetidas ao crivo do duty to mitigate the loss.

O último detalhe que a primeira parte do artigo 77 que merece atenção é quanto ao momento em que a parte prejudicada tem que mitigar seu prejuízo. A resposta não se difere da conclusão que se chegou no Título II, Capítulo 3, item 3.2.3.1. A parte prejudicada, assim que estiver segura que a parte contrária se tornará (ou se tornou) inadimplente, terá o ônus de evitar ou minimizar seus prejuízos, ainda que a quebra ocorra antes do termo estipulado (anticipatory breach).

Inaugurando a análise acerca da segunda parte do artigo 77 , a redação leva ao entendimento de que a falha na observância da mitigação e a alegação da parte inadimplente neste sentido levam a uma redução do valor indenizatório. Assim, a CISG adota o pensamento que a mitigação se desdobra numa simples limitação das perdas e danos indenizáveis, enquanto que neste estudo defendemos a ideia de que a norma de mitigação nem ao menos faz surgir um direito indenizatório se desrespeitada ${ }^{404}$. A alegação da parte inadimplente, no entanto, não é imprescindível, já que o magistrado tem o poder de apreciar o caso e mensurar adequadamente o valor da indenização.

\footnotetext{
${ }^{402}$ Conforme estudado no Título I, Capítulo 2, supra.

403 CHENGWEI, Liu. Remedies for Non-performance: Perspectives from CISG, UNIDROIT Principles \& PECL. Setembro de 2003. Disponível em: http://www.cisg.law.pace.edu/cisg/biblio/chengwei-77.html. Acesso em 07/02/2014.

${ }^{404}$ Conforme Título I, Capítulo 2, item 2.1.1.3.
} 
No mesmo sentido que o desenvolvido no item referente ao pressuposto de exigibilidade processual ${ }^{405}$, defende a doutrina acerca da CISG que é na própria ação indenizatória que a parte inadimplente tem a possibilidade de alegar a inobservância da mitigação ${ }^{406}$. Afinal, é o momento em que a parte prejudicada cobra a parte inadimplente por todos os danos e esta tem o ônus processual de provar fato modificativo, extintivo ou impeditivo do direito daquela.

A inobservância da mitigação, por si só, não tem o condão de causar a rescisão do contrato. A CISG delimitou que a sua única consequência é a limitação da indenização por perdas e danos, mas isto não impede que haja a rescisão em razão do inadimplemento ou outro motivo que a parte apresente. A observância do disposto no artigo 77 não pode ser diretamente exigida - afinal, como ônus, a norma de mitigação não é exigível, consoante visto anteriormente ${ }^{407}$ - e a falha da parte prejudicada em cumprir seus termos não pode ser motivo de rescisão contratual.

\subsection{Exclusão da responsabilidade de mitigação}

A CISG prevê situações em que a parte não tem a obrigação de agir, pois a sua responsabilidade pelo dano está excluída. Não são hipóteses exclusivas do duty to mitigate the loss, mas a ele se aplicam. Estão previstos nos artigos 79 e 80:

\section{Artigo 79}

(1) Nenhuma das partes será responsável pelo inadimplemento de qualquer de suas obrigações se provar que tal inadimplemento foi devido a motivo alheio à sua vontade, que não era razoável esperar fosse levado em consideração no momento da conclusão do contrato, ou que fosse evitado ou superado, ou ainda, que fossem evitadas ou superadas suas consequências.

(2) Se o inadimplemento de uma das partes for devido à falta de cumprimento de terceiro por ela incumbido da execução total ou parcial do contrato, esta parte somente ficará exonerada de sua responsabilidade se:

(a) estiver exonerada do disposto no parágrafo anterior; e

(b) o terceiro incumbido da execução também estivesse exonerado, caso lhe fossem aplicadas as disposições daquele parágrafo.

\footnotetext{
${ }^{405}$ Vide Título II, Capítulo 3, item 3.3., supra.

${ }^{406}$ HONNOLD, John O. Uniform Law for International Sales under the 1980 United Nations Convention. $3^{\mathrm{a}}$ ed. 1999. p. 457. Disponível em http://www.cisg.law.pace.edu/cisg/biblio/honnold.html. Acesso em 07/02/2014.

${ }^{407}$ Acerca da inexigibilidade da norma de mitigação, em razão da natureza jurídica de ônus, vide o Título I, Capítulo 2, itens 2.1.1.2.6. e 2.1.1.3.1., supra.
} 
(3) A exclusão prevista neste artigo produzirá efeito enquanto durar o impedimento.

(4) A parte que não tiver cumprido suas obrigações deve comunicar à outra parte o impedimento, bem como seus efeitos sobre sua capacidade de cumpri-las. Se a outra parte não receber a comunicação dentro de prazo razoável após o momento em que a parte que deixou de cumprir suas obrigações tiver ou devesse ter tomado conhecimento do impedimento, esta será responsável pelas perdas e danos decorrentes da falta de comunicação.

(5) As disposições deste artigo não impedem as partes de exercer qualquer outro direito além da indenização por perdas e danos nos termos desta Convenção.

\section{Artigo 80}

Uma parte não poderá alegar o descumprimento da outra, na medida em que tal descumprimento tiver sido causado por ação ou omissão da primeira parte.

As hipóteses previstas no artigo 79 não se diferem daquelas nomeadas como caso fortuito ou de força maior no direito brasileiro. São situações em que a parte não tem qualquer controle sobre o acontecimento dos fatos, ficando impedida de adimplir com sua obrigação por causa de fatores humanos extraordinários ou da natureza imprevisíveis. Quanto a análise sobre este assunto, remetemos a leitura ao Título II, Capítulo 4, item 4.6.

O artigo 80, por sua vez, trata da culpa exclusiva da parte prejudicada pelos danos sofridos, não podendo ela alegar descumprimento da obrigação pela outra se a sua conduta é que causou o inadimplemento. A questão é instigante se transportada a hipótese para o caso do duty to mitigate the loss. A conduta indevida da parte que provoca o inadimplemento da outra só reforça a necessidade de observância do ônus de mitigação. Com efeito, a parte inadimplente só se encontra nesta situação porque a outra parte assim determinou por sua ação ou omissão e, por isso, esta outra requerer indenização por perdas e danos (inclusive os evitáveis) é um agir totalmente contrário ao princípio da boa-fé e, principalmente, ao que determina a norma de mitigação.

Se a parte prejudicada é quem determinou o inadimplemento, esta não poderá, nos termos do artigo 80, imputar os prejuízos à outra, tampouco cobrar pelos danos decorrentes do inadimplemento que ela mesma causou. Seria um total desvirtuamento dos pressupostos de existência ${ }^{408}$ do duty to mitigate the loss, pois não preenchidos de forma voluntária, mas coercitivamente, em vista de prejudicar ainda mais a situação da parte inadimplente.

${ }^{408}$ Conforme estudados no Título II, Capítulo 3, item 3.2. 


\subsection{Hipóteses específicas de mitigação na CISG}

Além de trazer uma regra geral para todos os casos em que recai o ônus da mitigação sobre os contratos de compra e venda internacional de mercadorias, a própria CISG regulamenta medidas específicas que as partes podem adotar para mitigar seu prejuízo. São situações mais comuns, típicas da relação jurídica que regula, concedendo ao tratado esta possibilidade de prever hipóteses e preenchê-las com as regras cabíveis.

O primeiro dispositivo neste sentido é o artigo 75 . Dispõe que se o contrato for rescindido e se, em modo e prazo razoáveis após a rescisão, o comprador proceder a uma compra substitutiva ou o vendedor a uma venda substitutiva, a parte que exigir a indenização poderá obter a diferença entre o preço do contrato e o preço estipulado na operação substitutiva, assim como quaisquer outras perdas e danos exigíveis. A aplicação do dispositivo está adstrita à efetiva realização da operação substitutiva ${ }^{409}$.

Esta operação nada mais é do que uma medida adequada para a mitigação do prejuízo tomada pelo credor em razão do inadimplemento do devedor. O credor comprador ou vendedor - busca no mercado outro comprador ou vendedor com interesse na celebração de um contrato de compra e venda. A diferença entre o preço do contrato e o preço estipulado na operação substitutiva será parte do valor indenizatório, pois se trata de um dano inevitável. As demais despesas que resultaram na mitigação do prejuízo também poderão ser cobradas ${ }^{410}$. Assim, o artigo 75 trata das consequências da concretização de uma medida adequada, não perigosa e não onerosa adotada pelo credor na hipótese.

O artigo 76, por sua vez, trata da situação em que o credor não realizou a operação substitutiva prevista no artigo 75. Aduz o aludido dispositivo:

Artigo 76

(1) Se o contrato for rescindido e as mercadorias tiverem preço corrente, a parte que exigir a indenização das perdas e danos poderá, se não houver procedido à compra substitutiva ou à venda substitutiva previstas no artigo 75 , obter a

\footnotetext{
${ }^{409}$ LOPES, Christian Sahb Batista. A mitigação dos prejuízos no direito contratual. Belo Horizonte, 2011. Tese (Doutorado em Direito). Faculdade de Direito da Universidade Federal de Minas Gerais. p. 80.

${ }^{410}$ Tal possibilidade decorre da referência feita ao artigo 74, o qual prevê o princípio da reparação integral do dano. Determina referido dispositivo que as perdas e danos consistirão no valor equivalente ao prejuízo sofrido, inclusive lucros cessantes, sofrido pela outra parte em consequência do descumprimento. Esta indenização não pode exceder à perda que a parte inadimplente tinha ou devesse ter previsto no momento da conclusão do contrato, levando em conta os fatos dos quais tinha ou devesse ter tido conhecimento naquele momento, como consequência possível do descumprimento do contrato.
} 
diferença entre o preço fixado no contrato e o preço corrente no momento da resolução, bem como quaisquer outras perdas e danos exigíveis em razão do artigo 74. Não obstante, se a parte que exigir a indenização houver resolvido o contrato após ter tomado posse das mercadorias, aplicar-se-á o preço corrente no momento de tomada de posse, em lugar do preço corrente no momento da rescisão.

(2) Para os fins do parágrafo anterior, o preço corrente será aquele do lugar onde a entrega das mercadorias deveria ter sido efetuada ou, na falta de preço corrente nesse lugar, o preço praticado em outra praça que puder razoavelmente substituílo, levando-se em consideração as diferenças no custo de transporte das mercadorias.

A situação aqui se difere pelo credor, podendo realizar a operação substitutiva, não o fez, perdendo o direito à indenização completa. Só poderá receber o equivalente à diferença entre o preço fixado no contrato e o preço corrente no momento da resolução, além das perdas e danos nos termos do artigo 74. Trata-se de uma verificação abstrata das perdas e danos resultantes da inobservância de realização da operação substitutiva, em que o credor tem a sua indenização limitada à diferença estipulada no artigo.

A solução não é diferente daquilo que já foi estudado nos capítulos anteriores. A diferença calculada nos termos do artigo 76 são os danos classificados como inevitáveis, já que é uma perda que a parte prejudicada teve com o inadimplemento da outra. Por isso, deve ser indenizado. Por outro lado, como não realizou a operação substitutiva e, consequentemente, não evitou o dano classificado como evitável, a parte prejudicada não poderá ser indenizada no valor do preço corrente da mercadoria.

Na sequência, a Seção VI do Capítulo V da CISG trata das medidas de conservação das mercadorias tanto pelo comprador quanto pelo vendedor quando existe uma disputa entre eles. É certo que em alguns momentos podem existir desavenças entre as partes contratantes, criando dúvidas acerca da conformidade de certas mercadorias com o contratado ou se determinada conduta libera a outra de adimplir com sua obrigação ${ }^{411}$. Para dirimir tais casos, a CISG estabeleceu nos artigos 85 a 88 medidas de conservação, que nada mais são que medidas específicas de mitigação, próprias da relação jurídica que o tratado internacional regulamenta.

O artigo 85 define a obrigação do vendedor de conservar as mercadorias quando o comprador atrasa o pagamento ou o recebimento delas. As medidas tomadas devem ser razoáveis, estando as mercadorias em sua posse ou podendo delas dispor de outra forma. E

${ }^{411}$ HONNOLD, John O. Uniform Law for International Sales under the 1980 United Nations Convention. $3^{\mathrm{a}}$ ed. 1999. p. 519. Disponível em http://www.cisg.law.pace.edu/cisg/biblio/honnold.html. Acesso em 07/02/2014. 
enquanto não for reembolsado dos gastos que teve com a conservação, o vendedor pode reter as mercadorias.

O entendimento não tem como ser outro senão de um ônus de mitigação. Com o inadimplemento, o vendedor conserva as mercadorias para que o seu prejuízo não aumente ainda mais. Afinal, trata-se de um dano evitável que, se alguma medida razoável não for adotada, o vendedor não poderá ser indenizado. Em um ponto a CISG vai além e traz uma solução para o vendedor: se ele não for indenizado pelas despesas que teve com a conservação das mercadorias, isto é, com a medida razoável adotada, então ele poderá reter as mercadorias até que haja o reequilíbrio financeiro das partes.

O artigo 86, por sua vez, trata da conservação pelo comprador:

Artigo 86

(1) Se o comprador tiver recebido as mercadorias e tiver a intenção de exercer o direito de recusa conferido pelo contrato ou pela presente Convenção, deverá adotar as medidas que forem razoáveis, atendidas as circunstâncias, para a respectiva conservação. O comprador terá direito de reter as mercadorias até que obtenha do vendedor o reembolso dos gastos razoáveis que tiver realizado.

(2) Se as mercadorias remetidas ao comprador tiverem sido colocadas à disposição deste no lugar de destino e o comprador exercer o direito de recusa, este deverá tomar posse das mercadorias por conta do vendedor, quando for isso possível sem pagamento do preço, inconvenientes ou gastos não razoáveis. Esta disposição não se aplicará quando o vendedor ou a pessoa autorizada a tomar posse das mercadorias por conta deste estiver presente no local de destino. Os direitos e obrigações do comprador que tomar posse das mercadorias nos termos do presente parágrafo se regerão pelo parágrafo precedente.

A recusa pelo comprador não o exonera de conservar as mercadorias, efetuando gastos razoáveis para a sua manutenção. O dispositivo também reflete o outro lado da hipótese prevista no artigo 85: se o vendedor não reembolsar o comprador das despesas que teve com a conservação, este terá o direito de reter as mercadorias. De fato, como as situações são semelhantes, os comentários realizados para o artigo 85 servem também para o artigo 86.

A segunda parte do dispositivo trata do caso de as mercadorias já terem sido enviadas ao comprador, exercendo este o direito de recusa. Ele também terá que conservar os bens por conta do vendedor se isto for possível dentro das limitações do próprio artigo, salvo se o vendedor estiver no local. 
$\mathrm{O}$ artigo 87 se aplica tanto para o comprador quanto para o vendedor. Dispõe que aquele que estiver obrigado a conservar as mercadorias poderá depositá-las em armazém de terceiro se esta medida não for onerosa. $\mathrm{O}$ dispositivo nada mais que evidencia mais uma medida razoável para a mitigação do prejuízo, haja vista que o depósito com terceiro, se for adequado e não oneroso, é eficiente para evitar ou reduzir o dano.

Por fim, o artigo 88 trata inicialmente da possibilidade de a parte vender as mercadorias em conservação caso a outra parte retarde por um tempo não razoável tomar posse delas, aceitar sua devolução ou pagar o preço dos gastos de sua conservação. Para tanto, a parte tem que avisar previamente sobre sua intenção. No segundo item o dispositivo trata das mercadorias de rápida deterioração ou que impelem gastos desarrazoados, autorizando a parte a vendê-las e, se possível, comunicar deste ato a parte contrária com antecedência. Finalmente, o artigo autoriza que a parte que vender as mercadorias poderá reter valor equivalente ao que gastou com a conservação, devendo entregar o resto do saldo à outra parte.

Enquanto a primeira parte do artigo 88 traz uma opção de venda das mercadorias, a segunda traz uma obrigação ${ }^{412}$. Isto porque a rápida deterioração ou a onerosidade da conservação não se mostram como medidas razoáveis para a mitigação do dano. Assim, se a parte não vender as mercadorias, não terá direito ao reembolso pelas despesas havidas com a conservação: o dano era evitável e, mesmo assim, não procedeu corretamente a parte. Na terceira parte, o duty to mitigate the loss é evidente: a retenção do valor da venda equivalente ao que gastou com a conservação serve de indenização pela eficiente mitigação realizada.

\subsection{Jurisprudência aplicando o artigo 77 da CISG}

Alguns julgados de países que já adotaram a CISG há um bom tempo servem para ilustrar a aplicação do artigo 77 em casos concretos. Ademais, auxiliam na compreensão do duty to mitigate the loss como instituto, podendo-se extrair valiosos exemplos de correta incidência do ônus de mitigação pelo credor.

${ }^{412}$ Idem, ibidem. p. 527-528. 
No caso Delchi Carrier, S.p.A. v. Rotorex Corp. ${ }^{413}$, a empresa Rotorex, fabricante de compressores para ar condicionado, celebrou contrato com a empresa Delchi, fabricante de ar condicionado, para o fornecimento de dez mil e oitocentos compressores. A entrega dos compressores seria feita por três envios consecutivos. No momento em que o segundo envio estava a caminho, a Delchi descobriu que os compressores possuíam defeito de fabricação, já que não estavam em conformidade com o que havia sido estabelecido no contrato. A Delchi então negou os produtos do segundo envio, ficando estes depositados no porto. Como meio de mitigar o prejuízo, a Delchi encomendou de terceiros compressores para ar condicionado. Por fim, propôs ação indenizatória contra a Rotorex pelos danos causados pelo inadimplemento contratual.

A Corte estadunidense decidiu que era o caso de inadimplemento contratual e que a Delchi tinha direito de ser indenizada pelos prejuízos, nos termos do artigo 77 da CISG. Assim, a Delchi foi indenizada pelas despesas incorridas na tentativa de remediar a situação de a Rotorex enviar compressores errados, pelas somas pagas pela contratação de terceiros para o fornecimento de compressores para ar condicionado, pelo custo de armazenar os compressores defeituosos no porto e pelos lucros cessantes em razão do inadimplemento.

Outro caso interessante pode ser encontrado na jurisprudência alemã. No caso $R$. Motor S.n.c. v. M. Auto Vertriebs $\mathrm{GmbH}^{414}$, a empresa italiana R. Motor comprou onze carros no valor de DM 400.000 da empresa alemã M. Auto Vertriebs. Para tanto, a empresa italiana precisava dar uma garantia bancária, o que foi feito no valor de DM 55.000. Cinco carros foram entregues primeiro no mês de agosto e os outros seis seriam entregues dois meses depois, em outubro. Chegado o mês de outubro, a empresa italiana informou que não iria mais aceitar os seis carros, dada a enorme flutuação da moeda no período. Requereu, então, que a empresa alemã adiasse a entrega dos veículos. No começo de novembro a empresa alemã cancelou todos os pedidos que tinha com os seus fornecedores e demandou o pagamento da garantia bancária. A empresa italiana, por sua vez, requereu a devolução do valor da garantia e perdas e danos. O Tribunal alemão decidiu que a M. Auto Vertriebs não mitigou razoavelmente seus danos, já que mesmo tendo cumprido sua prestação, poderia ter se utilizado das disposições dos artigos 61 e 74

${ }^{413}$ ESTADOS UNIDOS. Delchi Carrier, S.p.A. v. Rotorex Corp., Nos. 185, 717, Dockets 95-7182, 95-7186 (2nd Cir. 1995). Disponível em: http://cisgw3.law.pace.edu/cases/940909u1.html. Acesso em 15/02/2014.

${ }_{414}$ ALEMANHA. R. Motor S.n.c. v. M. Auto Vertriebs GmbH, 7 U 1720/94 (OLG München 1995). Disponível em: http://www.cisg.law.pace.edu/cisg/wais/db/cases2/950208g1.html. Acesso em 15/02/2014. 
da CISG para remediar a situação. Como nunca declarou estar rescindido o contrato com a R. Motor, então era o caso de incidência do duty to mitigate the loss.

Em um caso austríaco ${ }^{415}$, as partes combinaram a venda de uma escavadeira pelo valor de DM 120.000, sendo que o vendedor havia adquirido o produto para revenda por DM 80.000. Em data combinada para uma inspeção, foi descoberto um problema hidráulico na escavadeira, consertado posteriormente pelo vendedor. Logo em seguida, foi combinada uma data para o pagamento do preço pactuado, o que foi descumprido pelo comprador. Este prometeu ao vendedor que pagaria no mês seguinte. Após inúmeras outras cobranças, o vendedor vendeu a escavadeira para outro comprador pelo preço de DM 80.000. O vendedor, então, propôs ação indenizatória contra o comprador pelo prejuízo de DM 40.000 que sofreu cumulado com $4 \%$ de lucros cessantes. A Corte austríaca decidiu que o vendedor cumpriu o disposto no artigo 77 da CISG e, por isso, tinha direito a receber a indenização pleiteada.

A Corte suíça ${ }^{416}$ também possui um caso peculiar quanto ao momento da adoção das medidas razoáveis para mitigação do prejuízo. Uma empresa alemã foi contratada para fornecer a uma empresa suíça um produto químico, ficando esta responsável pela entrega. A empresa suíça, contudo, não tomou qualquer atitude quanto a entrega do produto, mesmo com a empresa alemã concedendo tempo adicional para realizá-la. Após outras falhas, e com a certeza que a empresa suíça não cumpriria a entrega, a empresa alemã declarou o contrato rescindido e revendeu dois dias depois os produtos químicos para terceiros por valor menor que o contratado com a empresa suíça. O valor foi menor em razão da oscilação de mercado. A empresa alemã, então, propôs ação indenizatória pelos prejuízos em razão da diferença de valores.

A Corte suíça decidiu a favor da empresa alemã, ressaltando que a espera de dois dias para a adoção da operação substitutiva foi razoável, ainda que tenha havido oscilação do valor de mercado. O cálculo da indenização foi realizado levando em consideração o benefício recebido pela operação substitutiva e a diferença no preço que seria pago pelo comprador original.

415 ALEMANHA. Oberlandesgericht Graz, 4 R 219/01k, 24 de janeiro de 2002. Disponível em: http://cisgw3.law.pace.edu/cases/020124a3.html. Acesso em 15/02/2014.

416 SUÍÇA. R. GmbH v. O. AG, A3 2001 34, 12 de dezembro de 2002. Disponível em: http://cisgw3.law.pace.edu/cases/021212s1.html. Acesso em 15/02/2014. 


\section{MITIGAÇÃO NAS INICIATIVAS INTERNACIONAIS}

Afora todas as legislações apresentadas neste estudo em que há previsão da norma de mitigação, existem outras iniciativas que buscam consolidá-la - além de outras matérias - tanto no plano doutrinário quanto como um esboço de dispositivo legal. Se por um lado não possuem a força coercitiva de uma lei, tais iniciativas revelam um esforço da comunidade jurídica de criar uma previsão expressa do duty to mitigate the loss dada a sua importância nas relações jurídicas.

A primeira iniciativa que se pode mencionar é a do International Institute for the Unification of Private Law (UNIDROIT). Trata-se de instituto independente situado em Roma criado para modernizar, harmonizar e coordenar a prática comercial entre Estados, criando regramentos uniformes para atingir este objetivo. Deste contexto surgiram os chamados Princípios do UNIDROIT para contratos comerciais. A sua primeira publicação ocorreu em 1994, sendo atualizados e republicados em 2004 e, finalmente, em 2010. Consoante dispõe o preâmbulo do documento, são princípios criados para regulamentar de maneira geral os contratos comerciais internacionais, podendo ser aplicados quando assim as partes quiserem.

O duty to mitigate the loss está presente no artigo 7.4.8:

Artigo 7.4.8 - Mitigação do prejuízo

(1) A parte inadimplente não é responsável pelo prejuízo sofrido pela parte prejudicada na medida em que esses prejuízos poderiam ter sido reduzidos pela adoção de medidas razoáveis por esta última.

(2) A parte prejudicada está autorizada a recuperar qualquer despesa razoavelmente incorrida na tentativa de reduzir o prejuízo ${ }^{417}$.

A regra é próxima, mas não semelhante às características estudadas anteriormente acerca da mitigação, provocando a realização de algumas considerações. Em primeiro lugar, nota-se que em nenhum momento o artigo traz expressões como "dever", "ônus" ou "limitação". Os Princípios do UNIDROIT, portanto, se esquivaram de adentrar na polêmica da natureza jurídica da mitigação, tratando somente da responsabilidade das

${ }^{417}$ Tradução livre do original. 
partes e de seu funcionamento ${ }^{418}$. A consequência da inobservância da mitigação é mais radical do que aquela prevista na CISG e defendida ao longo deste estudo: a falha do credor leva à total irresponsabilidade do devedor pelos danos evitáveis. Não existe previsão de um meio termo, em que a indenização é apenas reduzida por circunstâncias peculiares $^{419}$.

A forma como o dispositivo foi redigido também apresenta uma mudança de foco se comparada com a CISG. Enquanto esta tem uma redação que parece favorecer muito mais a parte prejudicada, o princípio do UNIDROIT parece se preocupar igualmente com os interesses tanto do credor como do devedor ${ }^{420}$. Em um aspecto, entretanto, ambas as normas convergem: não trazem qualquer significado para o que seria uma medida razoável para evitar os danos. E novamente, a doutrina repete o entendimento da CISG, que seria uma noção verificável casuisticamente ${ }^{421}$.

Ainda em comparação com a CISG, os Princípios do UNIDROIT também trazem artigos que fazem referência às chamadas operações substitutivas. Os artigos 7.4.5 e 7.4.6 seguem a mesma linha de raciocínio dos artigos 75 e 76 da CISG $^{422}$ :

Artigo 7.4.5 - Prova de prejuízo no caso de operação substitutiva

Nos casos em que a parte prejudicada tenha extinguido o contrato e tenha realizado uma operação substitutiva em tempo e maneira razoáveis, poderá cobrar a diferença entre o preço do contrato e o preço da operação substitutiva, além dos danos por qualquer outro prejuízo.

Artigo 7.4.6 - Prova de prejuízo pelo preço corrente

(1) Nos casos em que a parte prejudicada tenha extinguido o contrato e não tenha realizado uma operação substitutiva, mas existe um preço corrente para a prestação contratada, ela poderá recuperar a diferença entre o preço do contrato e o preço corrente no tempo que o contrato foi extinto, além dos danos por qualquer outro prejuízo.

(2) Preço corrente é o preço geralmente cobrado por mercadorias entregues ou serviços realizados em circunstâncias comparáveis no lugar onde o contrato deveria ter sido adimplido ou, se não existe preço corrente neste local, o preço corrente em outro local que parece razoável ser tomado como referência ${ }^{423}$.

\footnotetext{
${ }^{418}$ LOPES, Christian Sahb Batista. A mitigação dos prejuízos no direito contratual. Belo Horizonte, 2011. Tese (Doutorado em Direito). Faculdade de Direito da Universidade Federal de Minas Gerais. p. 84.

${ }^{419}$ Vide as situações trabalhadas no Título II, Capítulo 5, principalmente dos exemplos trazidos no item 5.7.

${ }^{420}$ OPIE, Elisabeth. Commentary on the manner in which the UNIDROIT Principles

may be used to interpret or supplement Article 77 of the CISG. Janeiro de 2005. Disponível em http://www.cisg.law.pace.edu/cisg/principles/uni77.html. Acesso em 07/02/2014.

${ }^{421}$ Idem, ibidem.

${ }^{422}$ Vide Título III, Capítulo 6, item 6.5.

423 Tradução livre do original.
} 
A União Europeia também desenvolveu, através da Comissão Europeia de Justiça, proposta de criação de uma norma uniforme de compra e venda entre os países que a integram. Trata-se da proposta de um Direito Comum Europeu de Compra e Venda (Common European Sales Law).

Embora seja importante fazer-lhe referência, os conteúdos de seus dispositivos em nada diferem em relação aos dos Princípios do UNIDROIT. Assim, o artigo 163 possui redação idêntica ao artigo 7.4.8 dos Princípios do UNIDROIT, que cuida da norma de mitigação. Os artigos 164 e 165, embora tenham redação apenas semelhante, não diferem em seu conteúdo do que está contido nos artigos 7.4.5 e 7.4.6 dos Princípios do UNIDROIT. Por isso, como não trazem nenhuma novidade ou diferença nestes tópicos, os comentários tecidos acerca dos Princípios do UNIDROIT também valem para este caso.

Vale, entretanto, ressaltar o seu artigo $5^{\circ}$, o qual traz um conceito de razoabilidade, aplicável a toda proposta:

\footnotetext{
Art. 5: Razoabilidade

1. Razoabilidade deve ser objetivamente determinada, levando em conta a natureza e a finalidade do que está sendo feito, as circunstâncias do caso e quaisquer usos e práticas de comércio ou profissões envolvidas.

2. Qualquer referência ao que se pode esperar de ou por uma pessoa, ou em uma situação particular, é uma referência para o que pode ser razoavelmente esperado $^{424}$.
}

As críticas a este conceito e a análise pormenorizada da razoabilidade já foram desenvolvidas neste estudo ${ }^{425}$. Esta é, inclusive, a concepção de medida razoável que a doutrina mais comumente defende para se definir a necessidade de observância pelo credor do duty to mitigate the loss, o que já foi por nós criticado ${ }^{426}$.

O mesmo ocorre com os Princípios de Direito Contratual Europeu (Principles of European Contract Law - PECL). Sendo uma consolidação de entendimentos acerca do

\footnotetext{
424 Tradução livre do original.

${ }^{425}$ Vide Título II, Capítulo 3, item 3.2.3 supra.

${ }^{426}$ CHENGWEI, Liu. Remedies for Non-performance: Perspectives from CISG, UNIDROIT Principles \& PECL. Setembro de 2003. Disponível em: http://www.cisg.law.pace.edu/cisg/biblio/chengwei-77.html. Acesso em 07/02/2014. Vide também o Título III, Capítulo 6, item 6.3 supra.
} 
direito contratual praticado nos países da Europa, o PECL funciona da mesma maneira que os Princípios do UNIDROIT, ou seja, dependem da aceitação das partes para serem a ele submetidas. Inspirados na CISG e nos próprios Princípios do UNIDROIT, foi concebida pela Comissão sobre o Direito Contratual Europeu (conhecida também por Comissão Lando, pois foi coordenada pelo professor Ole Lando).

A norma de mitigação, com redação idêntica ao dos Princípios do UNIDROIT, está prevista na PECL no artigo 9:505. Na mesma esteira, os artigos 9:506 e 9:507 tratam das operações substitutivas, se realizadas ou não, respectivamente. Também em nada inovam o que já havia sido desenvolvido pelo UNIDROIT. No tocante à razoabilidade, o mesmo conceito da Common European Sales Law é trazido no artigo 1:302.

Por fim, há a Minuta Comum de Referência (Draft Common Frame of Reference DCFR). Trata-se de documento criado pelo Grupo de Estudo sobre o Código Civil Europeu e o Grupo de Pesquisa sobre o Direito Privado da Comissão Europeia, com o intuito de ser uma base para a criação de normas sobre direito contratual europeu, inspiração e educação sobre o assunto ${ }^{427}$.

No tocante à norma de mitigação, o DCFR não se difere do que já fora apresentado acerca do PECL e da Common European Sales Law. Os artigos 3:705, 3:706 e 3:707 repetem o que está contido nos artigos 9:505, 9:506 e 9:507 do PECL. O artigo 1:104, por sua vez, tem redação idêntica ao artigo $5^{\circ}$ da Common European Sales Law, que trata da razoabilidade.

${ }^{427}$ VON BAR, Christian; CLIVE, Eric; SCHULTE-NÖLKE, Hans. Principles, definitions and model rules of European Private Law. Draft Common Frame of Reference (DCFR): Interim Outline Edition. Munique: Sellier, 2008. p. 3 e 7. 


\section{CONCLUSÃO}

Verificando a complexidade das relações jurídicas do mundo moderno, é de inegável importância a existência de mecanismos no ordenamento jurídico para a resolução dos mais diversos conflitos que possam surgir. Inegável, igualmente, que é impossível ser realizada a previsão legal de todas as situações, até porque a imaginação do hoje é limitada perto das possilidades que o futuro fornecerá. E também se mostra inviável pensar em uma legislação extremamente específica, regulamentando os mínimos detalhes concretos do direito obrigacional, pois recairia em um volume infindável de normas jurídicas.

Neste diapasão é que fica evidente a importância de fórmulas em sistemas abertos, os quais podem englobar uma gama de situações concretas, bastando ao aplicador a regulamentação do caso dentro das balizas previamente estabelecidas. Ao mesmo tempo em que inibe a ausência total de normas sobre determinado aspecto da relação jurídica em apreço, também evita a proliferação intensa e indesejável de regras.

Por isso que, pela análise da incorporação do duty to mitigate the loss no direito civil brasileiro por este estudo, verificou-se a sua compatibilidade com os ditames do princípio da boa-fé. Ao estabelecer a observância de uma regra de comportamento leal, probo e honesto na sua concepção objetiva, a boa-fé dedica múltiplas funções para coordenar a relação entre as partes. Dentre suas funções, destaca-se a função delimitadora de direito subjetivos, na qual se pode extrair a norma de mitigação.

O exercício irregular do direito por alguém, ainda que somente repercuta prejudicialmente no próprio patrimônio, também é obstado pela boa-fé, tendo em vista que é conduta que falta com a lealdade, confiança e cooperação necessárias em uma relação jurídica, seja ela contratual ou extracontratual. A norma de mitigação, extraída dessa função limitadora, tem por objeto a vedação ao credor de exigir e receber indenização por danos que por ele poderiam ser evitados pela adoção de esforços razoáveis.

Também, entendendo o abuso de direito como um dos desdobramentos da função delimitadora de direitos subjetivos do princípio da boa-fé, o artigo 187 faz-se presente na Parte Geral do Código Civil. Assim, o dispositivo, como cláusula geral que é, serve de porta para a entrada da boa-fé na ordem civil em seu aspecto extracontratual. Não seria o ideal em função da sua redação deficiente - assim como ocorre com os artigos 113 e 422 
do Código Civil -, mas fundamentalmente atrela o exercício de direitos à observância da boa-fé, com todas as suas funções.

O abuso de direito se apresenta como uma ramificação do princípio da boa-fé, já que esta serve de parâmetro para o reconhecimento de um exercício que extrapola os limites subjacentes. As demais estruturas presentes no artigo 187 do Código Civil, bons costumes e fins sociais e econômicos, não são aptos a vedar o exercício irregular de um direito. Os bons costumes dizem respeito à moral social, enquanto que os fins sociais e econômicos da funcionalização do exercício, isto é, o impacto que ele terá nas conjunturas sociais e econômicas. Dessa maneira, sendo o abuso de direito fundado exclusivamente na boa-fé, não há razão para haver um intermediário.

Também se combate o abuso de direito pelo próprio funcionamento da norma de mitigação, em uma análise posterior ao descumprimento da norma de mitigação, que não faz surgir um direito à indenização do credor pelos danos agravados, já que o devedor só é responsável por aquilo que era inevitável e pelo prejuízo causado pela inexecução de sua obrigação. No duty to mitigate the loss, inexiste direito à indenização pelo o que era evitável, pois o credor tem que mitigar ou evitar o agravamento do seu dano. Não há como abusar de um direito que não possui.

A proibição do venire contra factum proprium também se mostra como um fundamento inapropriado. Diferentemente do duty to mitigate the loss, a vedação do comportamento contraditório tutela a confiança entre as partes, já que censura uma segunda conduta contrária à expectativa legítima criada pela primeira. Ademais, também merece críticas por conta de a própria proibição do venire contra factum proprium se fundamentar no abuso de direito e, consequentemente, na boa-fé. A solução não é outra senão atribuir finalmente o fundamento ao princípio da boa-fé.

A responsabilidade civil, apesar do apelo do direito francês, não pode ser fundamento da norma de mitigação, pois transforma a verificação da mitigação pelo credor em um fator verificável caso a caso. Acaba por abandonar um modelo de comportamento apreciável pelo juiz, tarefa esta que a boa-fé como criadora de standards possibilita. Além disso, a criação de uma solução judicial para o caso concreto pela cláusula geral da boa-fé se torna inócua, pois a importância no caso não é a postura do credor, mas o nexo da ocorrência dos fatos. Ou seja, deixa importantes aspectos axiológicos de conduta honesta e proba de lado para simples verificação da sucessão de fatos, o que pode resultar na existência de decisões judiciais conflitantes sobre casos semelhantes. 
A culpa exclusiva da vítima e a culpa concorrente também incorrem nos mesmos problemas que a causalidade, havendo, ainda, um agravante: não se pode falar em culpa se não existe uma norma jurídica anterior que defina determinada conduta como culposa. Assim, não havendo uma anterior norma de mitigação, é indevido dizer que o comportamento negligente com seu próprio patrimônio é culposo, pois ao credor cabe dispor, como quiser, do que é seu. Tratar a conduta simplesmente como culposa é esvaziar seu conteúdo. Portanto, o duty to mitigate the loss é pressuposto da culpa, e não o contrário.

Estabelecida, então, dentro do princípio da boa-fé, a norma de mitigação se revela não como um dever jurídico anexo, mas na verdade como um ônus. $\mathrm{O}$ dever jurídico traz necessariamente a correspondência de ser exigível pela parte contrária; quem está a ele submetido está juridicamente compelido a cumpri-lo e, fundamentalmente, seu descumprimento acarreta em uma sanção. O dever jurídico atua em favor do interesse alheio. Tais pressupostos são inconciliáveis com o duty to mitigate the loss, tendo em vista que a mitigação do prejuízo é realizada em favor de interesse pessoal. É o próprio credor que quer evitar ou minimizar as perdas e danos ao seu próprio patrimônio e ele é quem agirá para tanto.

Por isso, comunga-se com maior facilidade atribuir à norma de mitigação a natureza jurídica de ônus. A inobservância do duty to mitigate the loss apenas faz com que o credor não alcance a vantagem econômica pretendida, afinal, não cumpriu seu ônus de evitar ou minizar os prejuízos que estavam ao seu alcance, isto é, dentro do campo da evitabilidade. Não conservou o seu próprio direito; não tutelou o próprio patrimônio quando assim poderia fazer e, por isso, não terá direito a ser indenizado pelo devedor inadimplente naquilo que deixou de mitigar.

Neste sentido é que se criticou a expressão duty to mitigate the loss: não há na verdade um dever. Ocorre que, com a sua difusão por esta alcunha, não parece ser oportuna sua modificação, sob o risco de causar mais confusão do que elucidação sobre o instituto em comento.

Foram identificados três pressupostos de existência da norma de mitigação: inadimplemento, existência de um prejuízo imputável ao devedor e possibilidade razoável de o credor amenizar os efeitos do prejuízo ou evitá-lo. O primeiro deles diz respeito ao inadimplemento do devedor que deu início à cadeia de eventos que atraem a incidência da norma de mitigação. O segundo é a repercussão negativa que o inadimplemento realiza no 
patrimônio do credor. O devedor deve ser culpado pelo inadimplemento, isto é, não podem estar presentes as excludentes de ilicitude que lhe subtrairiam a responsabilidade. Só assim é que há a atração do ônus da mitigação, pois do prejuízo imputável ao devedor poderão surgir aqueles evitáveis apenas pelo credor.

O terceiro pressuposto é a razoável possibilidade de mitigação pelo credor. Em outras palavras, é a verificação no caso concreto se o credor tinha reais chances de evitar ou minimizar o prejuízo, sem que para isto fosse exigido um esforço além de sua capacidade. Entretanto, referida verificação é de difícil realização diante de cada caso concreto, já que a concepção do que é uma medida razoável é variável a medida da vivência de cada um, das experiências particulares. Assim, como meio de amenizar conclusões discrepantes sobre a razoabilidade no duty to mitigate the loss, foi proposta a regra de aferição da razoabilidade.

Dividida em duas partes e estas em diversas etapas, a regra de aferição da razoabilidade impõe balizas mais claras e objetivas para assegurar ao credor quando terá que cumprir o ônus da mitigação e ao magistrado se houve o seu devido cumprimento. Trata-se de uma maneira, portanto, de evitar decisões judiciais com conclusões diversas sobre situações semelhantes.

A primeira parte é exclusiva do credor, o qual verificará se terá que cumprir o ônus da mitigação. Em primeiro lugar, deverá verificar se existe alguma medida para a mitigação e se esta é adequada. Medida adequada é aquela que se enquadra no propósito determinado, que pareça ser o recomendável para a situação, guardadas as especificidades do caso. Sendo adequada, em seguida parte-se para a verificação se a medida é perigosa e onerosa.

Medida perigosa significa dizer que apresenta algum risco para a vida do credor. Medida onerosa é a que causa despesas que superam o valor do prejuízo ou que ultrapasse o valor que o credor poderá bancar em razão de sua condição financeira ou, ainda, que atinja a sua reputação. Se a resposta afirmativa para a medida perigosa ou onerosa, então o credor não precisará adotá-la, pois não se mostra razoável. Caso a resposta for negativa, então há incidência do duty to mitigate the loss e, por isso, o credor tem o ônus de mitigar.

A segunda parte da regra de aferição da razoabilidade é exclusiva do magistrado, o qual verificará a incidência da norma de mitigação no caso concreto e o seu cumprimento ou não pelo credor. Este procedimento só se inaugura caso haja a propositura de ação de 
indenização por perdas e danos pelo credor, pleiteando o ressarcimento pelos prejuízos evitáveis. Assim, haverá a abertura para o devedor discutir dentro do processo se o credor observou o duty to mitigate the loss. Esta situação denominamos de pressuposto de exigibilidade processual.

O magistrado então percorrerá as mesmas etapas da primeira fase, mas questionando se a medida adotada pelo credor foi adequada, não perigosa e não onerosa. Adicionalmente, terá que aferir a eficiência da medida, isto é, se atingiu o objetivo almejado. Neste ponto, poderá se deparar com medidas totalmente eficientes, parcialmente eficientes ou ineficientes. Para cada uma haverá uma consequência distinta. Por fim, o magistrado aferirá se o credor auferiu lucro com a mitigação, o que reduzirá o quantum indenizatório.

Sedimentado todo este arcabouço teórico, o levantamento da jurisprudência brasileira não é animador. Na maioria das decisões pesquisadas, o duty to mitigate the loss foi aplicado de maneira equívoca, total ou parcialmente. Em muitas situações, inclusive, foi confundido com outros institutos jurídicos que, embora de aproximada conceituação, possuem características divergentes marcantes. É o caso, por exemplo, da diferença da norma de mitigação e supressio, deveres jurídicos anexos do princípio da boa-fé, do exercício tardio de um direito, prescrição, da culpa concorrente, etc. Em outras situações, embora houvesse o reconhecimento correto da incidência da mitigação, sua aplicação e consequências foram equivocadas.

O debate no Brasil acerca do duty to mitigate the loss, no entanto, só tende a aumentar. Isto porque foi incorporada ao ordenamento jurídico brasileiro a Convenção das Nações Unidas sobre Contratos de Compra e Venda Internacional de Mercadorias que, em seu artigo 77, traz norma jurídica específica de mitigação. Pela primeira vez o direito pátrio trouxe regra expressa do ônus do credor de adotar medidas razoáveis para a diminuição de seu prejuízo. Até então, e por tudo o que havia sido desenvolvido neste estudo, tratava-se somente de norma extraída do princípio da boa-fé. Ainda assim, é preciso atenção para o detalhe que referido tratado internacional regulamenta o comércio internacional de mercadorias, ou seja, a norma de mitigação nele inserida só se aplica neste âmbito.

Esta acaba sendo uma pequena evidência do nível de desenvolvimento do duty to mitigate the loss no direito externo, sobretudo nos países de common law. Mesmo que existam indícios de concretização da norma de mitigação no direito romano, ainda que não por esta alcunha, é certo que muito do que já foi debatido e pesquisado sobre a doutrina das 
consequências evitáveis precisa ser também refletido no direito interno. Até porque, como se viu, muitos dos aspectos aplicados naqueles ordenamentos jurídicos são compatíveis com o brasileiro, necessitando de singelas adaptações, as quais foram feitas neste estudo. Inclusive, se mostra medida de urgência, pois em diversas iniciativas internacionais o duty to mitigate the loss está incorporado, evidenciando a sua importância para as relações jurídicas modernas. 


\section{REFERÊNCIAS BIBLIOGRÁFICAS}

\section{Obras doutrinárias}

ALVIM, Agostinho Neves de Arruda. Da inexecução das obrigações e suas consequências. São Paulo: Saraiva, 1972.

BATES, Paul J. A Mitigation of Damages: A Matter of Commercial Common Sense. Advocate's Quarterly, v. 13, n. 3, p. 273-307, jan. 1992.

BECKER, Anelise. A doutrina do adimplemento substancial no Direito brasileiro e em perspectiva comparativista. In: Revista da Faculdade de Direito da Universidade Federal do Rio Grande do Sul, volume 9, nº 1, nov. 1993.

BETTI, Emilio. Teoria Generale delle Obbligazioni, v. 1, Prolegomeni, Funzione Economico-Sociale dei Rapporti d'Obbligazione. Milano: Giuffrè, 1953.

BITTAR, Carlos Alberto. Reparação civil por danos morais. $3^{\mathrm{a}}$ ed. rev. atual. e amp. São Paulo: Revista dos Tribunais, 1999.

BOBBIO, Norberto. O Positivismo Jurídico: Lições de Filosofia do Direito. São Paulo: Ícone, 2006.

CENDON, Paolo. Commentario al Codice Civile Artt. 2054-2059: Fatti illeciti. Circolazione di veicoli, responsabilità solidale, valutazione, danni non patrimoniali. Milão: Giuffré, 2009. p. 303.

CHENGWEI, Liu. Remedies for Non-performance: Perspectives from CISG, UNIDROIT Principles \& PECL. Setembro de 2003. Disponível em: http://www.cisg.law.pace.edu/cisg/biblio/chengwei-77.html. Acesso em 07/02/2014.

CHRISTENSEN, W. D.; Sharon. Professional Liability and Property Transactions. Sidnei: The Federation Press, 2004.

CLARK, John Kirkland. Let the Maker Beware. St. John's Law Journal. vol. 19, $\mathrm{n}^{\mathrm{o}} 2$, $2^{\mathrm{a}}$ ed., p. 85-94, abril de 1945.

COOTER, Robert; ULEN, Thomas. Law \& Economics. 5a ed. Harlow: Pearson AddisonWesley, 2008. 
CORDEIRO, Antonio Manuel da Rocha e Menezes. Da Boa Fé no Direito Civil. $4^{\mathrm{a}}$ reimpressão. Coimbra: Almedina, 2001.

. Tratado de direito civil português: introdução, doutrina geral, negócio jurídico. v.

1, t. 1., Coimbra: Almedina.

DIAS, Daniel Pires Novais. O duty to mitigate the loss no Direito Civil brasileiro e o encargo de evitar o próprio dano. Revista de Direito Privado. Ano 12. n. 45. jan./mar. 2011. p. 89-145.

DIDIER JÚNIOR, Fredie. Curso de Direito Processual Civil Vol. 2. $4^{\mathrm{a}}$ ed. São Paulo: Revista dos Tribunais, 2009.

Multa coercitiva, boa-fé processual e supressio: aplicação do duty to mitigate the loss no processo civil. Revista de Processo. vol. 171. São Paulo: Revista dos Tribunais, maio 2009.

DINIZ, Maria Helena. Curso de Direito Civil Brasileiro: responsabilidade civil. v. 7, 17. ed. São Paulo: Saraiva. 2003.

. Manual de Direito Civil. $1^{\text {a }}$ ed. São Paulo: Saraiva, 2011.

. O Problema da Liquidação do Dano Moral e o dos Critérios para a Fixação do Quantum Indenizatório. Atualidades Jurídicas, v. 2, p. 237-272. São Paulo: Saraiva, 2000.

DYSON, Andrew. Explaining the Avoidable Loss Rule of Mitigation. SLS Conference, Cambridge, 8 de setembro de 2011.

ENGISCH, Karl. Introdução ao pensamento jurídico. Trad. João Batista Machado. $6^{\mathrm{a}}$ ed. Lisboa: Calouste Gulbenkian, 1988.

EVERETT, John C. Mitigation of Damages - Effect of Plaintiff Choosing Among Reasonable Alternatives. Arkansas Law Review. Arkansas, v. 23, p. 132-135, 1969-1970.

FARIAS, Cristiano Chaves de; ROSENVALD, Nelson. Direito Civil: teoria geral. Rio de Janeiro: Lumen Juris, 2009.

FAUVARQUE-COSSON, Bénédicte; MAZEAUD, Denis. European Contract Law: Materials for a Common Frame of Reference: Terminology, Guiding Principles, Model Rules. Munique: European Law Publishers, 2008.

FERNÁNDEZ, Maximiliano Rodríguez. Concepto y alcance del deber de mitigar el daño en el derecho internacional de los contratos. Revista de Derecho Privado, $\mathrm{n}^{\mathrm{o}}$ 15, 
Universidad Externado de Colombia, 2008. Disponível em: http://www.cisg.law.pace.edu/cisg/biblio/rodriguez-fernandez.html. Acesso em: $10 / 03 / 2014$.

FIÚZA, César. Para uma releitura da teoria geral da responsabilidade civil. Disponível em: http://www.estig.ipbeja.pt/ ac_direito/CFiuza.pdf. Acesso em: 13/01/2014.

FORTIN, Lisa A. Why There Should Be a Duty to Mitigate Liquidated Damages Clauses. Hofstra Law Review. v. 38, p. 285-318, 2009-2010.

FRADERA, Vera Maria Jacob de. Pode o credor ser instado a diminuir o próprio prejuízo?. Revista Trimestral de Direito Civil. Rio de Janeiro. v. 5. n. 19. jul./set. 2004. p. 109-119.

GAGLIANO, Pablo Stolze. Duty to mitigate: Editorial $n^{o} 13$. Texto datado de 23/10/2010. Disponível em: http://pablostolze.ning.com/page/editoriais-1. Acesso em 04/03/2012 ; PAMPLONA FILHO, Rodolfo. Novo Curso de Direito Civil 4 Tomo I Contratos: teoria geral. $8^{\text {a }}$ ed. rev. atual. e ampl. São Paulo: Saraiva, 2012.

GARCIA, Enéas Costa. Responsabilidade pré e pós-contratual à luz da boa-fé. $1^{\mathrm{a}}$ ed. São Paulo: Juarez de Oliveira, 2003.

GILISSEN, John. Introdução histórica ao direito. Tradução por A. M. Hespanha e L. M. Macaísta Malheiros. 2a ed. Lisboa: Calouste Gulbenkian, 1995.

GOETZ, Charles J.; SCOTT, Robert E. The mitigation principle: toward a general theory of contractual obligation. Virginia Law Review. v. 69, p. 967-1024, setembro de 1983.

GOMES, Orlando. Contratos. $9^{\mathrm{a}}$ ed. Rio de Janeiro: Forense, 1983.

GONÇALVES, Carlos Roberto. Responsabilidade civil. 11ª ed. São Paulo: Saraiva, 2009.

GRAU, Eros Roberto. Nota sobre a distinção entre Obrigação, Dever e Ônus. Revista da Faculdade de Direito da Universidade de São Paulo. v. 77, p. 177-183, 1982.

GRINOVER, Ada Pellegrini et al. Código Brasileiro de Defesa do Consumidor comentado pelos autores do Anteprojeto. 9. ed. Rio de Janeiro: Forense Universitária, 2007.

GUSMÃO, Paulo Dourado de. Introdução à Ciência do Direito. $2^{\mathrm{a}}$ ed. Rio de Janeiro: Forense, 1960.

HABERMAS, Jürgen. Direito e Democracia; entre facticidade e validade - Volume I. Rio de Janeiro: Tempo Brasileiro, 2003. 
HILLMAN, Robert A. Keeping the Deal Together After Material Breach: Common Law Mitigation Rules, the UCC, and the Restatement (Second) of Contracts. University of Colorado Law Review. v. 47, p. 553-615, 1976.

HONNOLD, John O. Uniform Law for International Sales under the 1980 United Nations Convention. $\quad 3^{\text {a }}$ ed. 1999. p. 458-461. Disponível em http://www.cisg.law.pace.edu/cisg/biblio/honnold.html. Acesso em 07/02/2014.

IHERING, Rudolph Von. Der Geist des römischen Rechts auf den verschiedenen Stufen seiner Entwicklung. Leipzig: Leipzig Breitkopf und Hartel, 1924.

KELSEN, Hans. Teoria Geral do Direito e do Estado. $3^{\text {a }}$ ed. São Paulo: Martins Fontes, 2000.

KERR, A. J. Mitigation of loss: Problems Concerning the Onus of Proof. South African Law Journal. v. 98, p. 306-307, 1981.

KLEIN, Kevin C.; HININGER, Nicole G. Mitigation of Psychological Damages: An Economic Analysis of the Avoidable Consequences Doctrine and Its Applicability to Emotional Distress Injuries. Oklahoma City University Law Review, v. 29, p. 405-439, 2004.

KNAPP, Victor. Bianca-Bonell Commentary on the International Sales Law. Giuffrè: Milan, 1987. p. 559-567. Disponível em: http://www.cisg.law.pace.edu/cisg/biblio/knappbb77.html. Acesso em 07/02/2014.

LE PAUTREMAT, Solène. Mitigation of damage: a French perspective. International and Comparative Law Quarterly. Londres, v. 55, p. 205-217, 2006.

LITVINOFF, Saúl. Damages, Mitigation, and Good Faith. Tulane Law Review, New Orleans, v. 73, p. 1161-1195, 1999.

LOPES, Christian Sahb Batista. A mitigação dos prejuízos no direito contratual. Belo Horizonte, 2011. Tese (Doutorado em Direito). Faculdade de Direito da Universidade Federal de Minas Gerais.

MACDONALD, Elizabeth; KOFFMAN, Lawrence. The Law of Contract. $6^{\mathrm{a}}$ ed. Oxford: Oxford University Press, 2007.

MARINO, Francisco Paulo De Crescenzo. Interpretação do Negócio Jurídico. $1^{\text {a }}$ ed. São Paulo: Saraiva, 2011. 
MARTINS-COSTA, Judith. A Boa-fé no Direito Privado: sistema e tópica no processo obrigacional. São Paulo: Revista dos Tribunais, 2000.

; BRANCO, Gerson Luiz Carlos. Diretrizes Teóricas do Novo Código Civil Brasileiro. São Paulo: Saraiva, 2002.

MEDEIROS NETO, Xisto Tiago de. Dano moral coletivo. 2. ed. São Paulo: LTr, 2007. MONTEIRO, Washington de Barros. Curso de direito civil: direito das obrigações: $1^{a}$ parte. vol. 4. São Paulo: Saraiva, 1988.

MORAES, Maria Celina Bodin de. Danos à pessoa humana: uma leitura civilconstitucional dos danos morais. Rio de Janeiro: Renovar, 2003.

NEIRA, Lílian C. San Martín. La carga del perjudicado de evitar o mitigar el daño : Estudio histórico-comparado. Bogotá: Universidad Externado de Colombia, 2012.

NUNES, Luiz Antonio Rizzatto. Curso de direito do consumidor. $4^{\mathrm{a}}$ ed. São Paulo: Saraiva, 2009.

OPIE, Elisabeth. Commentary on the manner in which the UNIDROIT Principles may be used to interpret or supplement Article 77 of the CISG. Janeiro de 2005. Disponível em http://www.cisg.law.pace.edu/cisg/principles/uni77.html. Acesso em 07/02/2014.

ORGANIZAÇÃO DAS NAÇÕES UNIDAS. Brasil adere à Convenção da ONU sobre contratos internacionais de compra e venda de mercadorias. 5 de março de 2013. Disponível em: http://www.onu.org.br/brasil-adere-a-convencao-da-onu-sobre-contratosinternacionais-de-compra-e-venda-de-mercadorias/. Acesso em 21/03/2014.

PANTALEÃO, Leonardo. Teoria Geral das Obrigações: parte geral. $1^{\mathrm{a}}$ ed. Barueri: Manole, 2005.

POTHIER, Robert Joseph. Tratado das obrigações. Tradução por Adrian Sotero De Witt Batista e Douglas Dias Ferreira. Campinas: Servanda, 2001.

POVEDA VELASCO, Ignácio Maria. A Boa-Fé na Formação dos Contratos (Direito Romano), Revista de Direito Civil, Imobiliário, Agrário e Empresarial. São Paulo. v. 16. n. 61. p. 35-42. jul/set 1992.

Direito, Jurisprudência e Justiça no pensamento clássico (greco-romano). São Paulo: Revista da Faculdade de Direito, vol. 101, 2006. p. 21-32.

REALE, Miguel. Lições Preliminares de Direito. 29a ed. São Paulo: Saraiva, 2001. 
Filosofia do Direito. 20ª ed. São Paulo: Saraiva, 2002.

SÁENZ, Alfonso Castro. Metodologia y ciência jurídica: hacia un concepto de derecho romano. Revista de estudios histórico-jurídicos. Valparaíso, $\mathrm{n}^{\circ}$ 24, 2002. Disponível em: http://www.scielo.cl/scielo.php?script=sci_arttext\&pid=S071654552002002400001\&lng=es\&nrm=iso. Acesso em 10 de março de 2014.

SAIDOV, Djakhongir. Methods of Limiting Damages under the Vienna Convention on Contracts for the International Sale of Goods. Dezembro de 2001. Disponível em: http://cisgw3.law.pace.edu/cisg/biblio/saidov.html. Acesso em 07/02/2014.

SEVERO, Sérgio. Os danos extrapatrimoniais. São Paulo: Saraiva, 1996.

SILVA, Clóvis Couto e. A obrigação como processo. São Paulo: José Bushatsky, 1976. O Princípio da Boa-Fé no Direito Brasileiro e Português. In: Estudos de Direito Civil Brasileiro e Português. São Paulo: Editora Revista dos Tribunais, 1980.

SILVA, Virgílio Afonso da. Direitos Fundamentais - conteúdo essencial, restrições $e$ eficácia. $2^{\mathrm{a}}$ ed. São Paulo: Malheiros, 2010.

PEREIRA, Caio Mário da Silva. Instituições de Direito Civil - Vol. I. $21^{\mathrm{a}}$ ed. Rio de Janeiro: Forense, 2005.

Instituições de Direito Civil - Vol. III. 12ª ed. Rio de Janeiro: Forense, 2006.

TARTUCE, Flávio. A boa-fé objetiva e a mitigação do prejuízo pelo credor. Esboço do tema $e$ primeira abordagem. mar. 2005. Disponível em: http://www.flaviotartuce.adv.br/artigos/Tartuce_duty.doc. Acesso em: 14/09/2012 Direito Civil - Vol. 3 - Teoria Geral dos Contratos e Contratos em Espécie. $8^{\mathrm{a}}$ ed. São Paulo: Método, 2013.

THEODORO JÚNIOR, Humberto. Curso de Direito Processual Civil - Teoria Geral do Direito Processual Civil e Processo de conhecimento - Vol. I. $47^{\mathrm{a}}$ ed. Rio de Janeiro: Forense, 2007.

Curso de Direito Processual Civil - Processo de Execução e Cumprimento da

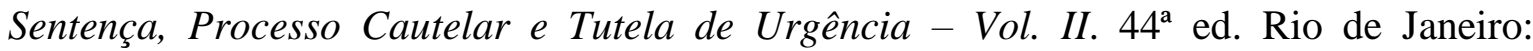
Forense, 2009. 
TOMASEVICIUS FILHO, Eduardo. Informação assimétrica, custos de transação, princípio da boa-fé. São Paulo, 2007. Tese (Doutorado em Direito). Faculdade de Direito da Universidade de São Paulo.

TRONCOSO, María Isabel. La obligación de tomar medidas razonables para evitar la extensión del daño. Revista de Derecho Privado, no 21, p. 353-391, julho-dezembro de 2011.

UNCITRAL. Explanatory Note by the UNCITRAL Secretariat on the United Nations Convention on Contracts for the International Sale of Goods. Disponível em: http://www.cisg.law.pace.edu/cisg/text/p23.html. Acesso em: 21/03/2014.

VON BAR, Christian; CLIVE, Eric; SCHULTE-NÖLKE, Hans. Principles, definitions and model rules of European Private Law. Draft Common Frame of Reference (DCFR): Interim Outline Edition. Munique: Sellier, 2008.

WAMBIER, Luiz Rodrigues et al. Curso Avançado de Processo Civil v. 1: Teoria Geral do Processo e Processo de Conhecimento. 10 ${ }^{\mathrm{a}}$ ed. São Paulo: Revista dos Tribunais, 2008. WILLISTON, Samuel; LORD, Richard A. A treatise on the law of contracts. Eagan: Thomson West, 1990.

WINDSCHEID, Bernhard. Lehrbuch des Pandektenrechts. Vol. 2. Frankfurt: Frankfurt a. M. Literarische Anstalt Rütten \& Loening, 1906.

ZANETTI, Cristiano de Sousa. A Mitigação do Dano e Alocação da Responsabilidade. Revista Brasileira de Arbitragem. n. 35. jul./ago./set. 2012. p. 28-36.

Responsabilidade pela Ruptura das Negociações. $1^{\mathrm{a}}$ ed. São Paulo: Juarez de Oliveira, 2005.

\section{Legislação}

ALEMANHA. Bürgerliches Gesetzbuch (BGB). Disponível em: http://www.gesetze-iminternet.de/bgb/. Acesso em 23.08.2012.

BRASIL. Constituição da República Federativa do Brasil. Brasília: Congresso Nacional, 1988. 
. Lei no 5.869, de 11 de janeiro de 1973. Institui o Código de Processo Civil. Brasília, Congresso Nacional, 1973.

. Lei ${ }^{\circ} 8.078$, de 11 de setembro de 1990. Dispõe sobre a proteção do consumidor e dá outras providências. Brasília, Congresso Nacional, 1990.

- Lei $\mathrm{n}^{\mathrm{o}}$ 10.406, de 10 de janeiro de 2002. Institui o Código Civil. Brasília: Congresso Nacional, 2002.

ESTADOS UNIDOS. Uniform Commercial Code. Disponível em: http://www.law.cornell.edu/ucc. Acesso em 05.03.2014.

Restatement (Second) of Contracts. Disponível em: http://www.lexinter.net/LOTWVers4/restatement_\%28second\%29_of_contracts.htm. Acesso em 05.03.2014.

ITÁLIA. Il Codice Civile Italiano. Disponível em: http://www.altalex.com/index.php?idnot=34794. Acesso em 23.08.2012.

ORGANIZAÇÃO DAS NAÇÕES UNIDAS. Convention on Contracts for the International Sale of Goods (CISG). Viena, 1980. Disponível em: http://www.cisg.law.pace.edu/cisg/text/treaty.html. Acesso em 17.07.2012.

PORTUGAL. Decreto-Lei n 47.344, de 25 de novembro de 1966. Código Civil Português. Disponível em: http://www.igf.minfinancas.pt/leggeraldocs/DL_47344_66_COD_CIVIL_INDICE.htm. Acesso em 17.07.2012.

REINO UNIDO. Sale of Goods Act, 1979. Disponível em: http://www.legislation.gov.uk/ukpga/1979/54. Acesso em 05.03.2014.

ROMA. (Império). Corpus Iuris Civilis. Disponível em: http://web.upmfgrenoble.fr/Haiti/Cours/Ak/. Acesso em 27.09.2012.

SUÍÇA. Schweizerisches Zivilgesetzbuch (ZGB). Disponível em: http://www.admin.ch/ch/f/rs/220/index.html. Acesso em: 23.08.2012.

UNIÃO EUROPEIA. Common European Sales Law. Disponível em: http://eurlex.europa.eu/LexUriServ/LexUriServ.do?uri=COM:2011:0635:FIN:EN:HTML. Acesso em: 14.01.2013. 
- Draft Common Frame of Reference. Disponível em: http://ec.europa.eu/justice/policies/civil/docs/dcfr_outline_edition_en.pdf. Acesso em: 14.01.2013.

UNIDROIT. Convenção de Haia, de $1^{\circ}$ de julho de 1964. Disponível em: http://www.unidroit.org/french/conventions/c-ulis.htm. Acesso em: 14.01.2013.

- Principles of International Commercial Contracts. Disponível em: http://www.unidroit.org/english/principles/contracts/principles2010/integralversionprincipl es2010-e.pdf. Acesso em: 14.01.2013.

\section{Jurisprudência (outras mencionadas ao longo do estudo encontradas nas obras doutrinárias acima referenciadas)}

ALEMANHA. Oberlandesgericht Graz, 4 R 219/01k, 24 de janeiro de 2002. Disponível em: http://cisgw3.law.pace.edu/cases/020124a3.html. Acesso em 15/02/2014.

R. Motor S.n.c. v. M. Auto Vertriebs GmbH, 7 U 1720/94 (OLG München 1995). Disponível em: http://www.cisg.law.pace.edu/cisg/wais/db/cases2/950208g1.html. Acesso em 15/02/2014.

BRASIL. Superior Tribunal de Justiça, $3^{\mathrm{a}}$ Turma. Recurso Especial $\mathrm{n}^{\mathrm{o}}$ 758.518/PR. Recorrente: Muretama Edificações e Empreendimentos Ltda. Recorrido: Sérgio Meca de Lima. Rel. Min. Vasco Della Giustina (Desembargador convocado do TJ/RS), votação unânime, j. 17/06/2010.

. Superior Tribunal de Justiça, $4^{\mathrm{a}}$ Turma. Recurso Especial nº 1.325.862. Recorrente: Joel Samways Neto. Recorrido: Mara Regina de Oliveira Trevizan. Rel. Min. Luis Felipe Salomão, votação unânime, j. 05/09/2013.

—. Tribunal de Justiça do Estado do Espírito Santo, 2a Câmara Cível. Agravo de Instrumento $\mathrm{n}^{\mathrm{o}}$ 24139022149. Agravante: Vila Real Serviços Especializados Ltda. ME. Agravada: Casa e Café Assessoria Profissional Ltda. ME. Rel. Des. José Paulo Calmon Nogueira da Gama, decisão monocrática, j. 04/12/2013. 
. Tribunal de Justiça do Estado do Espírito Santo, 2a Câmara Cível. Apelação ${ }^{\circ}$ 38040012593. Apelante: Banestes S/A. Apelado: Espólio de Luciano Sélia. Rel. Des. José Paulo Calmon Nogueira da Gama, decisão monocrática, j. 02/02/2011.

—. Tribunal de Justiça do Estado do Espírito Santo, 4 ${ }^{\mathrm{a}}$ Câmara Cível. Apelação no 24060084241. Apelante: União de Professores Ltda. Apelada: Maria dos Anjos Herzog de Moraes. Rel. Des. Catharia Maria Novaes Barcellos, votação unânime, j. 10/03/2009.

—. Tribunal de Justiça do Estado do Espírito Santo, 4 ${ }^{\mathrm{a}}$ Câmara Cível. Apelação no 24050215359. Apelante: Neusa Araujo Guimarães Lopes. Apelado: Centro Educacional Charles Darwin Ltda. Rel. Des. Catharia Maria Novaes Barcellos, votação unânime, j. $19 / 06 / 2007$.

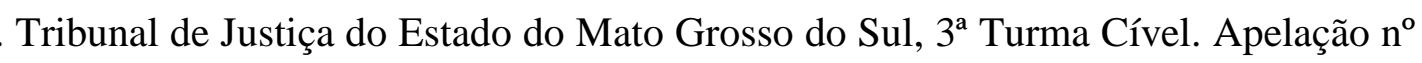
2009.001940-8/0000-00. Apelante: Segurança Adm. e Corretora de Seguros Ltda. Apelada: Vivo S.A. Rel. Des. Fernando Mauro Moreira Marinho, votação unânime, j. 24/04/2007.

—. Tribunal de Justiça do Estado do Mato Grosso do Sul, $3^{\text {a }}$ Turma Cível. Apelação Cível no 2009.022658-4/0000-00. Apelante: Banestado Administradora de Cartões de Crédito Ltda. Apelado: Antonio Gentil Rodrigues. Rel. Des. Rubens Bergonzi Bossay, votação unânime, j. 21.09.2009.

Tribunal de Justiça de Minas Gerais, $12^{\mathrm{a}}$ Câmara Cível. Agravo de Instrumento $\mathrm{n}^{\circ}$ 1.0024.12.270283-0/001. Agravante: Lucas Antonio de Assis. Agravado: Banco Semear S/A. Rel. Des. Domingos Coelho, votação unânime, j. 12/12/2012.

—. Tribunal de Justiça de Minas Gerais, 12a Câmara Cível. Agravo de Instrumento no 1.0702.11.024301-2/001. Agravante: Banco Itaú S/A. Agravado: João Dorneles dos Santos Dias. Rel. Des. José Flávio de Almeida, votação unânime, j. 14/09/2011.

- Tribunal de Justiça de Minas Gerais, 14 ${ }^{\mathrm{a}}$ Câmara Cível. Apelação Cível $\mathrm{n}^{\circ}$ 1.0701.09.287702-9/001. Apelante: Ismar Marcelino da Silva e outros. Apelado: Construtora Brilhante Ltda. Rel. Des. Rogério Medeiros, votação unânime, j. 09/02/2012.

- Tribunal de Justiça do Estado de Minas Gerais, 16 Câmara Cível. Apelação Cível $\mathrm{n}^{\mathrm{o}}$ 1.0701.07.183692-1/001. Apelantes/Apelados: Julio Ferreira dos Santos e outro e Felipe Raffaeli Ramos. Rel Des. Wagner Wilson, votação unânime, j. 11/03/2009. 
. Tribunal de Justiça do Estado do Paraná, 14ª Câmara Cível. Apelação Cível $n^{\circ}$ 1163274-3. Apelantes/Apelados: Paraná Banco S/A e Amaro Teofilo Monteiro. Rel. Des. Edgard Fernando Barbosa, votação unânime, j. 29/01/2014.

. Tribunal de Justiça do Estado do Paraná, $15^{a}$ Câmara Cível. Apelação Cível $n^{\circ}$ 755934-0. Apelantes/Apelados: Cooperativa de Crédito de Livre Admissão Maringá e Prestação de Serviços Radiológicos - TEC Imagem S/C. Rel. Des. Jucimar Novochadlo, votação unânime, j. 23/03/2011.

- Tribunal de Justiça do Estado de Pernambuco, $1^{\mathrm{a}}$ Câmara Cível. Apelação $\mathrm{n}^{\circ}$ 275195-9. Apelante: Associação Recifense de Educação e Cultura. Apelado: Banco Santander S/A. Rel. Des. Roberto da Silva Maia, votação unânime, j. 08/10/2013.

- Tribunal de Justiça do Estado de Pernambuco, $3^{\mathrm{a}}$ Câmara Cível. Agravo Regimental no 304623-5. Agravantes/Agravados: Tim Nordeste S.A. e Climart Comércio e Serviço Ltda. Rel Des. Bartolomeu Bueno, votação unânime, j. 05/12/2013.

_. Tribunal de Justiça do Estado do Piauí, 1ª Câmara Especializada Cível. Apelação Cível no 2012.0001.002277-0. Apelantes/Apelados: Posto Ladeira do Uruguai Ltda. e Ipiranga Produtos de Petróleo S/A. Rel. Des. Raimundo Eufrásio Alves Filho, votação unânime, j. 28/11/2012.

. Tribunal de Justiça do Estado do Rio de Janeiro, 9a Câmara Cível. Apelação Cível $n^{\text {o }}$ 0219297-89.2009.8.19.0001. Apelante: Cláudio César Maia de Bittencourt Lobo. Apelado: Banco Citibank S/A. Rel. Des. Roberto de Abreu e Silva, decisão monocrática, j. 28/09/2010.

_. Tribunal de Justiça do Estado do Rio de Janeiro, 9a Câmara Cível. Apelação no 0000976-75.2003.8.19.0073. Apelantes/Apelados: Carlos Augusto Lopes da Silva e Francisco Cesar de Azevedo. Rel. Des. Roberto de Abreu e Silva, decisão monocrática, j. 05/08/2013.

. Tribunal de Justiça do Estado do Rio de Janeiro, 16ª Câmara Cível. Apelação Cível

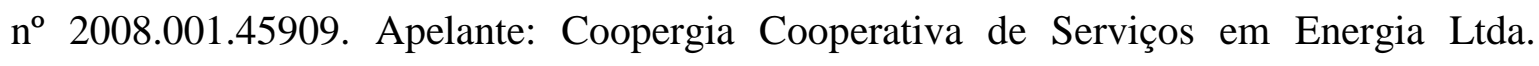
Apelada: Mercado Super Mikey da Praça Ltda. Rel. Des. Eduardo Gusmão Alves de Brito Neto, votação unânime, j. 16/09/2008.

—. Tribunal de Justiça do Estado do Rio de Janeiro, 19 ${ }^{\text {a }}$ Câmara Cível. Apelação no 1639488-93.2011.8.19.0004. Apelante: Banco Santander Brasil S/A. Apelado: Otavio 
Junior Gomes Ribeiro. Rel. Des. Eduardo de Azevedo Paiva, decisão monocrática, j. 21/03/2013.

Tribunal de Justiça do Estado do Rio de Janeiro, 27ª Câmara Cível Consumidor. Apelação n o 0392705-53.2011.8.19.0001. Apelante: Maria da Penha Duarte de Lima. Apelado: Itaú Unibanco S/A. Rel. Des. Marcos Alcino de Azevedo Torres, votação unânime, j. 31/01/2014.

Tribunal de Justiça do Estado do Rio Grande do Sul, 5ª Câmara Cível. Apelação Cível no 70025609579. Apelante: Prakasa Indústria e Comércio de Utilidades do Lar Ltda. Apelada: Mercomáquinas Indústria Comércio e Representações Ltda. Rel. Des. Umberto Guaspari Sudbrack, votação unânime, j. 20/05/2009.

- Tribunal de Justiça do Estado do Rio Grande do Sul, 6ª Câmara Cível. Apelação Cível no 70028036465. Apelante/Apelado: Tatiane Klein Gomes e Lojas Radan Ltda. Rel. Des. Liége Puricelli Pires, votação unânime, j. 09/04/2009.

—. Tribunal de Justiça do Estado do Rio Grande do Sul, 12a Câmara Cível. Apelação Cível n ${ }^{\circ}$ 7002.813.8113. Apelante: Elida Rosa Dutra Guzenski. Apelada: BRA Transportes Aéreos S.A. Rel. Des. Umberto Guaspari Sudbrack, votação unânime, j. 13/02/2009.

. Tribunal de Justiça do Estado do Rio Grande do Sul, 17ª Câmara Cível. Apelação Cível no 70032014458. Apelante: Banco do Estado de São Paulo S/A. Apelado: Moacir Sylvio Dal Castel. Rel. Des. Liége Puricelli Pires, votação unânime, j. 12/11/2009.

Tribunal de Justiça do Estado de Roraima, Câmara Única - Turma Cível. Apelação Cível no 0010.10.910849-7. Apelante: G. R. F. Apelado: E. C. J. Rel. Des. Almiro Padilha, votação unânime, j. 17/12/2013.

- Tribunal de Justiça do Estado de Santa Catarina, $3^{\mathrm{a}}$ Câmara de Direito Civil. Apelação Cível no 2011.030785-0. Apelante: Rosa Maria Tesser. Apelada: Banco do Brasil S/A. Rel. Des. Maria do Rocio Luz Santa Ritta, votação unânime, j. 17/07/2012.

- Tribunal de Justiça do Estado de Santa Catarina, 5a Câmara de Direito Civil. Apelação Cível no 2013.035089-5. Apelantes/Apelados: Sociedade Mãe da Divina Providência Hospital Nossa Senhora dos Prazeres e Edson Luiz Batista dos Santos. Rel. Des. airo Fernandes Gonçalves, votação unânime, j. 03/12/2013. 
. Tribunal de Justiça do Estado de Santa Catarina, 6a Câmara de Direito Civil. Apelação Cível no 2010.022856-8. Apelantes/Apelados: Luiz Olynto Teixeira Schirmer, Ilze Irmgard Schertel Cruz e o espólio de Léo Alberto Ramos Cruz. Rel. Des. Ronei Danielli, votação unânime, j. 19/10/2012.

_. Tribunal de Justiça do Estado de Santa Catarina, 6 ${ }^{a}$ Câmara de Direito Civil. Apelação Cível no 2012.036092-7. Apelante: Luci Video Locadora Ltda. Apelado: Valter Valdemiro Rodrigues Filho. Rel. Des. Ronei Danielli, votação unânime, j. 07/11/2013.

. Tribunal de Justiça do Estado de Santa Catarina, $1^{\text {a }}$ Turma de Recursos - Capital. Recurso Inominado n ${ }^{\circ}$ 2012.100782-0. Recorrente: Brasil Telecom S/A. Recorrida: Maria Goreti da Silva Vieira. Rel. Des. Margani de Mello, votação unânime, j. 07/02/2013.

. Tribunal de Justiça do Estado de São Paulo, $1^{\text {a }}$ Câmara de Direito Privado. Apelação Cível no 0006445-52.2005.8.26.0586. Apelantes: Laerte de Paiva Filho e outros. Apelado: Ariovaldo Furlanetto. Rel. Des. Cláudio Godoy, votação unânime, j. 12/03/2013.

—. Tribunal de Justiça do Estado de São Paulo, 16 ${ }^{\mathrm{a}}$ Câmara de Direito Privado. Apelação Cível no 1.170.013-1. Apelantes: Auto Posto Shopping Diadema Ltda. e outros. Apelada: Mercoil Distribuidora de Petróleo Ltda. Rel. Des. Windor Santos, votação por maioria, j. 03/07/2007.

- Tribunal de Justiça do Estado de São Paulo, 19a Câmara de Direito Privado. Apelação no 991.07.072632-5. Apelante: José Motta. Apelado: Banco do Brasil S/A. Rel. Des. Ricardo Negrão, votação unânime, j. 19/10/2010.

—. Tribunal de Justiça do Estado de São Paulo, 19a Câmara de Direito Privado, Apelação Cível nº 0000641-30.2004.8.26.0072. Apelantes/Apelados: Maria Elzy Caldeira Carvalho e Banco do Brasil S/A. Rel. Des. Ricardo Negrão, votação unânime, j. 04/03/2013.

. Tribunal de Justiça do Estado de São Paulo, $27^{\text {a }}$ Câmara de Direito Privado. Agravo de Instrumento $\mathrm{n}^{\mathrm{o}}$ 0266216-42.2012.8.26.0000. Agravantes: Imobiliária Plaza Ltda. e outro. Agravados: Djair Pirana e outra. Rel. Des. Campos Petroni, votação unânime, j. $16 / 04 / 2013$.

_. Tribunal de Justiça do Estado de São Paulo, 34 $4^{\text {a }}$ Câmara de Direito Privado. Apelação Cível com Revisão n 1036109-0/8. Apelante: Emersson Clássere. Apelado: 
Antônio Carlos Pereira e outros. Rel. Des. Rosa Maria de Andrade Nery, votação unânime, j. 27/06/2007.

. Tribunal Regional Federal da $5^{\mathrm{a}}$ Região, $3^{\mathrm{a}}$ Turma. Apelação Cível $\mathrm{n}^{\mathrm{o}}$ 2003.83.00.022344-0. Apelante: Caixa Econômica Federal. Apelado: Flávio Pereira do Amaral. Rel. Des. Leonardo Resende Martins, votação unânime, j. 03/09/2009.

ESTADOS UNIDOS. Delchi Carrier, S.p.A. v. Rotorex Corp., Nos. 185, 717, Dockets 957182, 95-7186 (2nd Cir. 1995). Disponível em: http://cisgw3.law.pace.edu/cases/940909u1.html. Acesso em 15/02/2014. Moore v. University of Notre Dame, 22 F. Supp. 2d 896, 906-07 (N.D. Ind. 1998). Disponível em: http://www.leagle.com/decision/199891822FSupp2d896_1813. Acesso em 20/02/2014.

. Parker v. Twentieth Century-Fox Film Corp., 474 P.2d 689 (Cal. 1970). Disponível em: http://law.justia.com/cases/california/cal3d/3/176.html. Acesso em 20/02/2014.

Simmons v. Erie Ins. Exch., 891 N.E.2d 1059, 1067 (Ind. Ct. App. 2008). Disponível em: http://www.leagle.com/decision/In\%20INCO\%2020080811097. Acesso em 20/02/2014.

INGLATERRA e GALES. Bulkhaul Ltd v Rhodia Organique Fine Ltd [2008] EWCA Civ 1452 (18 December 2008). Disponível em: http://www.bailii.org/ew/cases/EWCA/Civ/2008/1452.html. Acesso em 20/02/2014. Reichman \& Anor v Beveridge \& Anor, [2006] EWCA Civ 1659 (13 December 2006). Disponível em: http://www.bailii.org/ew/cases/EWCA/Civ/2006/1659.html. Acesso em 20/02/2014.

SUÍÇA. R. GmbH v. O. AG, A3 2001 34, 12 de dezembro de 2002. Disponível em: http://cisgw3.law.pace.edu/cases/021212s1.html. Acesso em 15/02/2014. 